MARCELO JABOUR RIOS

A NECESSIDADE DE REFORMA DO SISTEMA TRIBUTÁRIO BRASILEIRO COMO ELIMINAÇÃO DE ENTRAVES À INTEGRAÇÃO NO ÂMBITO DO MERCOSUL: ANÁLISE A PARTIR DE EXPERIÊNCIAS EUROPEIAS

TESE DE DOUTORADO

ORIENTADOR: PROFESSOR DOUTOR GUSTAVO FERRAZ DE CAMPOS MONACO

UNIVERSIDADE DE SÃO PAULO

FACULDADE DE DIREITO

São Paulo-SP

2014 


\title{
A NECESSIDADE DE REFORMA DO SISTEMA TRIBUTÁRIO BRASILEIRO COMO ELIMINAÇÃO DE ENTRAVES À INTEGRAÇÃO NO ÂMBITO DO MERCOSUL: ANÁLISE A PARTIR DE EXPERIÊNCIAS EUROPEIAS
}

\begin{abstract}
Tese apresentada à Banca Examinadora do Programa de Pós-Graduação em Direito, da Faculdade de Direito da Universidade de São Paulo, como exigência parcial para obtenção do título de Doutor em Direito, na área de concentração de Direito Internacional, sob orientação do Professor Doutor Gustavo Ferraz de Campos Monaco.
\end{abstract}

\section{UNIVERSIDADE DE SÃO PAULO \\ FACULDADE DE DIREITO}

São Paulo-SP 
Faculdade de Direito da Universidade de São Paulo

Serviço de Biblioteca e Documentação

Jabour Rios, Marcelo

A necessidade de reforma do sistema tributário brasileiro como eliminação de entraves à integração no âmbito do MERCOSUL: análise a partir de experiências europeias / Marcelo Jabour Rios; orientador Gustavo Ferraz de Campos Monaco -- São Paulo, 2014. 180 p.

Tese (Doutorado - Programa de Pós-Graduação em Direito Internacional) - Faculdade de Direito, Universidade de São Paulo, 2014.

1. União Europeia. 2. MERCOSUL. 3. Harmonização legislativa. 4. Imposto sobre o valor acrescido (IVA). 5. Integração. I. Ferraz de Campos Monaco, Gustavo, orient. II. Título. 
BANCA EXAMINADORA 
Para Alberico Gentili ${ }^{1}$ (in memoriam), por renovar a flama pelo estudo do direito internacional, à distância histórica de quinhentos anos.

\footnotetext{
${ }^{1}$ Italiano, advogado, doutor em direito romano, amante dos Digestos, protestante, "herege" condenado pela inquisição e proibido pelo Index. Influenciou diretamente os principais juristas que se dedicaram ao estudo do direito das gentes. Defendeu a primazia do direito como ciência suprema, acima da teologia e da filosofia, refutou as teorias tomistas e contribuiu para assentar as bases do direito internacional, mormente em relação aos limites do uso da força, ao respeito ao ser humano (direta ou indiretamente envolvido nos conflitos armados), à busca pela paz perpétua e à necessidade de cooperação internacional para mantê-la, aportes teóricos que podem ser claramente percebidos no mundo contemporâneo, especialmente na formação da Organização das Nações Unidas (ONU) na construção da União Europeia.
} 


\section{AGRADECIMENTOS}

O começo deste caminho trilhado nas "Arcadas" somente foi possível pelas mãos generosas do Professor Doutor Gustavo Ferraz de Campos Monaco. Tão jovem quanto brilhante, concedeu-me a honra de ser seu orientando na Faculdade de Direito do Largo de São Francisco. Todo começo, nos ensina Hannah Arendt, antes de tornar um evento histórico, é a manifestação da suprema capacidade do homem. Cada novo nascimento garante esse começo; ele é, na verdade, cada um de nós.

Elaborar uma tese exige, para além do silêncio e da solidão, a contribuição valiosa de muitas pessoas. Agradeço aos Professores da Vetusta Casa de Afonso Pena (FDUFMG), que despertaram o meu interesse pelo direito internacional e pelo direito tributário: Arthur José de Almeida Diniz, Sacha Calmon Navarro Coêlho, Misabel de Abreu Machado Derzi e José Luiz Quadros de Magalhães. Agradeço também aos Professores do Largo São Franciso (FDUSP) Claudia Perrone-Moisés (por possibilitar a travessia) Paulo Borba Casella (pela genial, valiosa e profícua contribuição à ciência do direito sobre o tema analisado) e Wagner Menezes (por recordar o valor da leitura dos clássicos).

Ao Professor Paulo de Barros Carvalho, que me concedeu a honra de lecionar no Instituto Brasileiro de Direito Tributário (IBET), todo o meu respeito, toda a minha admiração.

Em especial, a Francisca de Paula de Jesus, por me fazer acreditar em milagres. Afinal, o desprendimento para com as coisas e a abertura ao mistério nunca acontecem por si próprias - disse Heidegger. "Não nos sucedem de uma forma acidental, mas sim, de um pensar persistente e corajoso." 


\section{RESUMO}

RIOS, Marcelo Jabour. A necessidade de reforma do sistema tributário brasileiro como eliminação de entraves à integração no âmbito do MERCOSUL: análise a partir de experiências europeias. 2014. 180 p. Tese (Doutorado em Direito) - Faculdade de Direito da Universidade de São Paulo, São Paulo, 2014.

Os tratados internacionais firmados após a segunda metade do século XX, em particular aqueles que pretendem superar os tradicionais acordos de livre comércio ou união aduaneira, seguem desafiando o direito contemporâneo. Por serem mais ambiciosos, ultrapassam a clássica forma de cooperação entre países soberanos e exigem uma estrutura institucional mais elaborada, capaz de fazer emergir a vontade expressa nos tratados e de estabelecer as liberdades que serão asseguradas nesse novo ambiente, uma vez que a máxima um povo, um governo, um território, não o define. A experiência mundial bem sucedida que conseguiu erigir um "mercado comum", assim compreendido como um espaço sem fronteiras em cujo interior circulam livremente pessoas, serviços, mercadorias e capitais, foi a vivenciada pelas Comunidades Europeias. A clareza dos objetivos traçados, a capacidade de superar as fases de estagnação, a solidez das instituições e, sobretudo, o reconhecimento da supremacia do direito comunitário foram determinantes para o êxito europeu. O triunfo assentou-se, dentre tantos outros pilares, no processo de harmonização das legislações tributárias dos países membros, em especial as que alcançam o consumo de bens e serviços, razão pela qual é reconhecido, pela doutrina e jurisprudência comunitárias, como um dos principais motores da União Europeia. Após vários fracassos nas tentativas de aproximação dos países na América Latina, o Mercado Comum do Sul (MERCOSUL) foi idealizado para atingir o patamar de um mercado comum e reconhecer, entre os seus membros, as quatro liberdades fundamentais de um mercado integrado. Como a harmonização das legislações fiscais constitui uma etapa fundamental para a consecução desse espaço econômico sem fronteiras, a tese analisa as espécies tributárias que alcançam o consumo de bens e serviços nos países membros do MERCOSUL e avalia a possibilidade de avanço rumo à integração regional iniciada pela assinatura do Tratado de Assunção. Nesse sentido, demonstra em quais aspectos o sistema tributário brasileiro representa um importante entrave à integração no âmbito do MERCOSUL.

Palavras-chaves: União Europeia. MERCOSUL. Harmonização legislativa. Imposto sobre o Valor Acrescido (IVA). Integração. Regionalismo. 


\begin{abstract}
RIOS, Marcelo Jabour. The need for a tax reform in Brazil as a means to overcoming the barriers to integration within the MERCOSUR: an analysis based on the European experience. 2014. 180 p. Thesis (Doctor in Law) - Faculdade de Direito da Universidade de São Paulo, São Paulo, 2014.
\end{abstract}

The international treaties signed after the second half of the $20^{\text {th }}$ century, especially those meant to supersede the traditional free trade agreements or customs union, still challenge contemporary law. Given that they are more ambitious, they override the classic mode of cooperation between sovereign countries and survive on a more carefully elaborated institutional structure, capable of making the wills expressed in the treaties emerge and establish the freedoms that will be guaranteed in this new environment, once the maxim a people, a government a territory does not define it. The well succeeded world experience that led to the creation of a "common market", construed as a space with no boundaries, within which people, services, goods and capital circulate freely, was experienced by the European Union. The clarity with which the aims were set forth, the power to overcome stagnation spells, the solvency of the institutions and, above all, the recognition of the supremacy of the communitarian law were decisive in the consolidation of the European success. Triumph, among so many other pillars, played a role in the process of harmonization of the tax law of the member countries, especially the law that contemplates the consumption of goods and services, which is the reason why it is known for its communitarian doctrine and jurisprudence, as one of the compelling forces of the European Union. After a succession of frustrated attempts to bring together the Latin American counties, the Southern Common Market (MERCOSUR) was conceived to attain the status of a common Market and recognise, among its members, the four fundamental freedoms of an integrated Market. As the harmonization of the fiscal laws is a stage of prime importance in the construction of this boundless economic space, the thesis analyses the types of taxes that affect the consumption of goods and services in the MERCOSUR member-countries and evaluates the possibility for is advancement towards the regional integration set on train with the signature of the Asunción Treaty. In this sense, it highlights which aspects of the Brazilian tax system pose a serious barrier to integration within the context of MERCOSUR.

Keywords: European Union. MERCOSUR. Law harmonization. Value-Added Tax (VAT). Integration. Regionalism. 


\section{RÉSUMÉ}

RIOS, Marcelo Jabour. Rios, Marcelo Jabour. La nécessite de réforme du système fiscal brésilien visant l'élimination des entraves à l'intégration dans le cadre du MERCOSUL : analyse à partir de l'expérience européenne. 180 p. Thèse (Docteur en droit) - Faculdade de Direito da Universidade de São Paulo, São Paulo, 2014.

Les traités internationaux conclus après la deuxième moitié du XXème siècle, particulièrement ceux entendant surpasser les accords de libre-échange ou d'union douanière, continuent de défier le droit contemporain. Plus ambitieux, ils dépassent la forme classique de coopération entre les pays souverains en exigeant une structure institutionnelle plus élaborée, susceptible de faire émerger la volonté expresse dans les traités et d'établir les libertés qui seront assurées dans ce nouveau cadre, une fois que la maxime un peuple, un gouvernement, un territoire, ne le définit pas. Les communautés européennes ont expérimenté le succès mondial de la création d'un «marché commun », considéré comme un espace sans frontières à l'intérieur duquel les personnes, les services, les marchandises et les capitaux circulent librement. La clarté des objectifs établis, la capacité à surmonter les périodes de stagnation, la solidité des institutions et, surtout la reconnaissance de la suprématie du droit communautaire ont été déterminantes pour la réussite européenne. Le triomphe s'est appuyé, parmi tant d'autres piliers, sur le processus d'harmonisation des législations fiscales des pays membres, en particulier celles touchant la consommation de biens et de services, raison pour laquelle il est reconnu, par la doctrine et la jurisprudence communautaire, comme l'un des principaux moteurs de l'Union Européenne. Après plusieurs échecs des tentatives de rapprochement des pays en Amérique Latine, le Marché commun du sud (MERCOSUL) a été idéalisé pour atteindre le niveau d'un marché commun et reconnaître, parmi ses membres, les quatre libertés fondamentales d'un marché intégré. Comme l'harmonisation des législations fiscales constitue une étape fondamentale pour la consécution de cet espace économique sans frontières, la thèse analyse les types de taxation relatifs à la consommation de biens et de services dans les pays membres do MERCOSUL et évalue la possibilité d'avancer vers l'intégration régionale initiée par la signature du Traité d'Assomption. Dans ce sens, elle démontre sous quels aspects le système fiscal brésilien représente une entrave importante à l'intégration dans le cadre do MERCOSUL.

Mots-clés: Union Européenne. MERCOSUL. Harmonisation législative. Taxe sur la valeur ajoutée (TVA). Intégration. Régionalisme. 
"A história de nossa civilização, desde os fenícios até os nossos dias, mostra que os períodos mais prósperos da humanidade coincidem com aqueles de liberdade de intercâmbios. A intensificação das relações comerciais conduziu os povos a uma integração progressiva, inclusive institucional. Ao contrário, os períodos mais nefastos relacionam-se com o surgimento de sistemas protecionistas e autárquicos: Quando os estados cerraram as suas fronteiras aos fluxos de produtos, fecharam antes ou depois aos homens e logo às ideias. Os regimes totalitários começam sempre assim."

Alfonso Mattera

"Por trás da democracia como ordenamento jurídico, político e social está a sociedade aberta como aspiração àquela sociedade capaz de romper o espírito exclusivista de cada grupo, e de fazer emergir das trevas sociais o homem, o singular, a pessoa em sua dignidade e em sua inviolabilidade."

Norberto Bobbio 


\section{SUMÁRIO}

INTRODUÇÃ

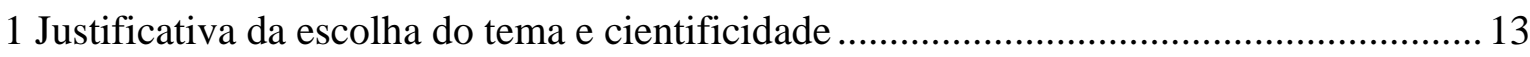

2 Delimitação do objeto e o seu desenvolvimento ............................................................. 16

Primeira Parte

O MERCADO COMUM: UM DIVISOR DE ÁGUAS

CAPÍTULO 1 - OS ACORDOS REGIONAIS DE INTEGRAÇÃO

1.1 Os acordos comerciais regionais firmados a partir da segunda metade do século XX...25

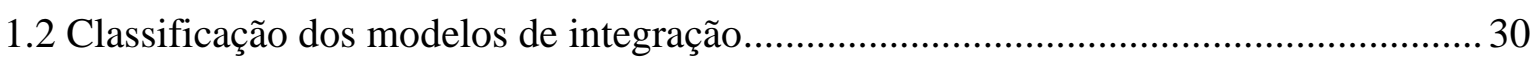

1.3 Harmonização das legislações tributárias: a pedra angular da constituição

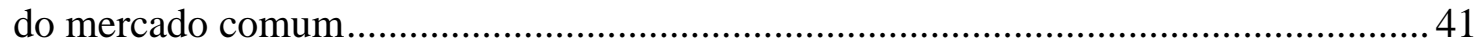

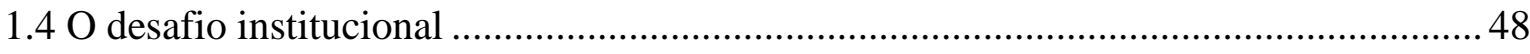

CAPÍTULO 2 - A EXPERIÊNCIA DE CONSTRUÇÃO DO MERCADO COMUM NO ÂMBITO DA UNIÃO EUROPEIA (UE)......................................50

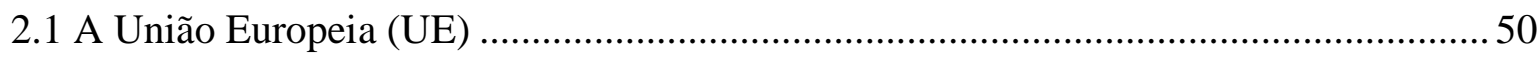

$2.2 \mathrm{O}$ mercado comum e os esforços para a harmonização da tributação indireta .............. 54

2.2.1 Primeira fase: o Tratado de Roma e as diretivas do Conselho ................................. 54

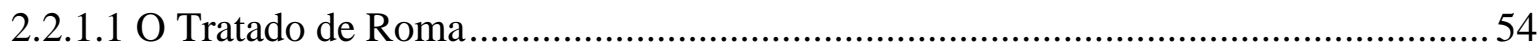

2.2.1.2 O direito comunitário: diretivas sobre a tributação do consumo ............................ 58

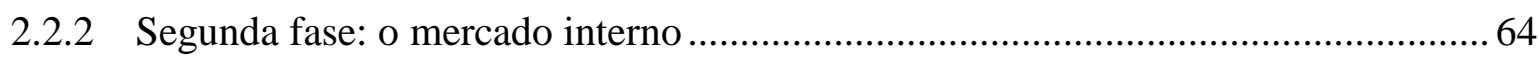

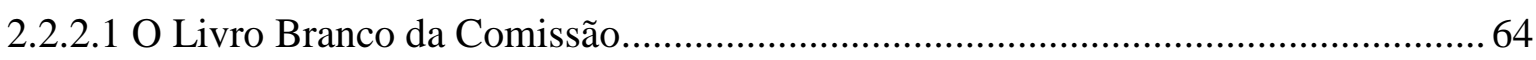

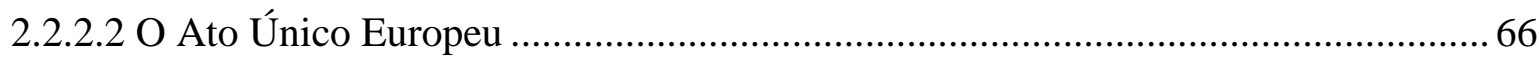

2.2.2.3 Alterações na Sexta Diretiva: Diretiva 91/680/CEE............................................ 67

$2.3 \mathrm{O}$ Imposto sobre o Valor Acrescido (IVA): expoente da acquis communautaire......... 68

2.4 As reformas dos sistemas tributários em Portugal e na Alemanha: reflexões

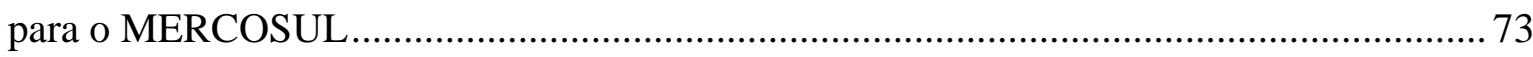

CAPÍTULO 3 - O PROJETO DE INTEGRAÇÃO REGIONAL 
3.1 A consagração do mercado comum como princípio constitutivo

3.2 Estrutura institucional e a incorporação do direito do MERCOSUL nos ordenamentos jurídicos dos Estados Partes 84

3.3 A harmonização dos impostos sobre o consumo de bens e serviços 87

CAPÍTULO 4 - O SISTEMA TRIBUTÁRIO DOS NOSSOS PARCEIROS: REPARTIÇÃO DE COMPETÊNCIAS E ESPÉCIES TRIBUTÁRIAS QUE ALCANÇAM O CONSUMO 91

4.1 Sistema tributário da República Federativa da Argentina .......................................... 91

4.1.1 Imposto geral sobre o consumo de bens e serviços (IVA) ..................................... 95

4.1.2 Imposto sobre os ingressos brutos das províncias argentinas ................................... 98

4.1.3 Outros impostos nacionais sobre o consumo de bens e serviços ............................. 102

4.2 Sistema tributário da República do Paraguai ................................................................. 104

4.2.1 Imposto geral sobre o consumo - o IVA do Paraguai ................................................ 107

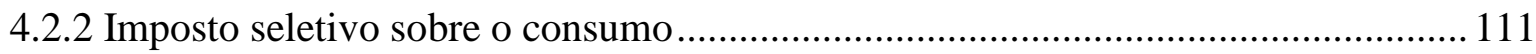

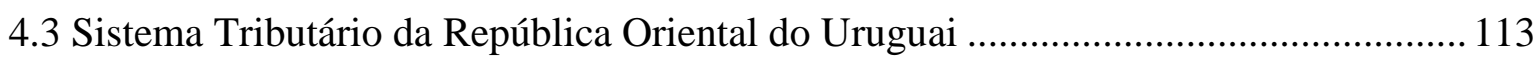

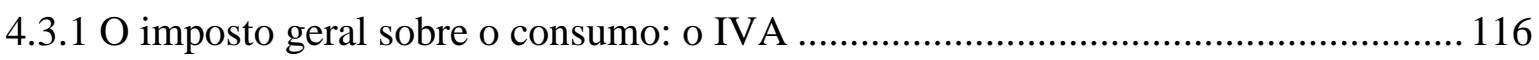

4.3.2 Imposto específico interno sobre o consumo (IMESI) ......................................... 120

4.4 Sistema tributário da República Bolivariana da Venezuela...................................... 122

4.4.1 Imposto geral sobre o consumo - IVA ……........................................................ 124

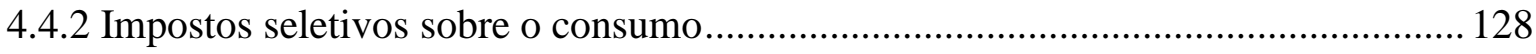

CAPÍTULO 5 - O SISTEMA TRIBUTÁRIO DA REPÚBLICA FEDERATIVA DO BRASIL: REPARTIÇÃO DE COMPETÊNCIAS E AS ESPÉCIES TRIBUTÁRIAS QUE ALCANÇAM O CONSUMO DE BENS E SERVIÇOS .......................................................................... 130

5.1 A tributação do consumo sob a égide do federalismo brasileiro .................................. 130

5.2 O Imposto sobre Produtos Industrializados (IPI) …................................................... 132

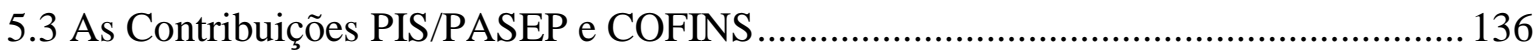

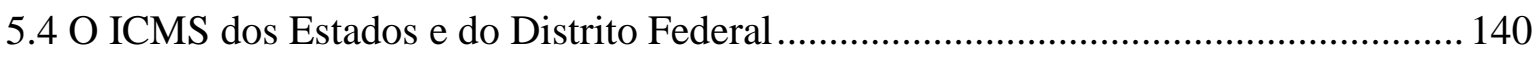

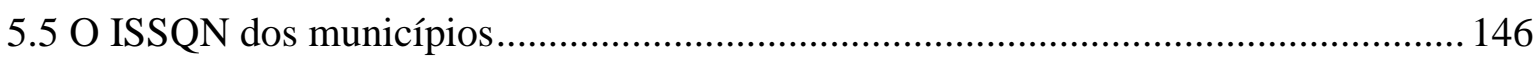

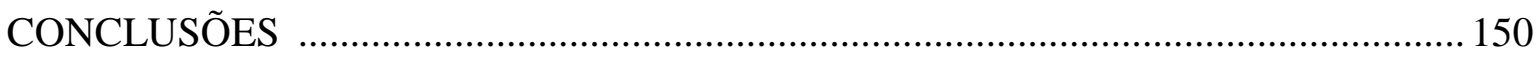




\section{INTRODUÇÃO}

\section{Justificativa da escolha do tema e cientificidade}

Os anseios contemporâneos de maior aproximação dos países foram gestados simultaneamente à percepção do declínio da noção de Estado estabelecida pelo direito constitucional e pelo direito internacional ao longo dos últimos quatro séculos.

A escolha do tema apoia-se na crença da superação do apogeu da autodeterminação e da emancipação dos povos e nações, e dirige o seu olhar para o fenômeno do reagrupamento jurídico-econômico em grandes espaços (regionalismo), a par de que "mais uma vez a Europa é o teatro de vanguarda desta mudança mundial".2

Paulo de Barros Carvalho, recordando as lições de Lourival Vilanova, assevera que o direito, como técnica de modificação social, não vem para representar o mundo, mas para alterá-lo, implantando valores ${ }^{3}$. Sendo assim, face à globalização da economia, a crescente internacionalização do direito e, em especial, o fenômeno do regionalismo, os juristas devem assumir o papel de supremos ideólogos e de arquitetos das novas realidades que se formam.

Entre nós, após vários fracassos nas tentativas de integração dos países na América Latina, o Mercado Comum do Sul (MERCOSUL) foi idealizado para atingir o patamar de um mercado comum. ${ }^{4}$

Se reconhecermos que estamos diante de uma proposta de integração inovadora, por agregar temas relacionados ao desenvolvimento e à democracia, perceberemos que esse projeto de integração é um marco de referência para os países que integram o mundo das "polaridades indefinidas". 5

\footnotetext{
${ }^{2}$ PIRES, Francisco Lucas. Introdução ao direito constitucional europeu: seu sentido, problemas e limites. Coimbra: Almedina, 1997. p. 7-10.

${ }^{3}$ CARVALHO, Paulo de Barros. Introdução. In: TOMÉ, Fabiana Del Padre. A prova no direito tributário. 3. ed. rev. São Paulo: Noeses, 2011. p. 13.

${ }^{4} \mathrm{O}$ artigo $1^{\circ}$ do Tratado do MERCOSUL estabelece: "Os Estados Partes decidem constituir um Mercado Comum, que deverá estar estabelecido a 31 de dezembro de 1994, e que se denominará "Mercado Comum do Sul" (MERCOSUL). (BRASIL. Decreto n. 350 de 21 de novembro de 1991. Promulga o tratado para a constituição de um mercado comum entre a República Argentina, a República Federativa do Brasil, a República do Paraguai e a República Oriental do Uruguai (TRATADO MERCOSUL). DOU, de 22.11.1991.

${ }^{5}$ LAFER, Celso. Sentido estratégico do Mercosul. In: MERCOSUL: desafios a vencer. São Paulo: Conselho Brasileiro de Relações Internacionais (CBRI), 1994. p. 10.
} 
Naturalmente, a criação do mercado comum exige rigorosos ajustes e adaptações internas, que incluem reformas constitucionais e modificações da legislação ordinária, "entretanto não mais conduzidas por mera cortesia ou conveniência - como pressupunha o conceito de comitas gentium -, mas em decorrência de obrigação jurídica internacionalmente assumida". ${ }^{6}$

Desde a sua concepção, o MERCOSUL é alvo de contundentes críticas. Há enormes dificuldades políticas, econômicas e institucionais para a sua concretização. A doutrina que expõe as suas fragilidades e assenta a distância entre a ideia e a possibilidade de colher os frutos da integração também assevera, com propriedade, que essa oportunidade não deveria ser desperdiçada, afinal, os fracassos são custosos.

Dentre os inúmeros desafios a serem superados, um ocupa lugar bastante relevante: a necessidade de harmonização das legislações tributárias dos Estados que pretendem avançar na integração.

Esse pilar é importante porque não se constrói um mercado comum sem essa harmonização, em grau elevado. É necessário estabelecer o equilíbrio, para evitar a fuga de pessoas, bens e capitais, e assegurar a livre concorrência, antes da remoção das barreiras físicas, técnicas e fiscais.

A justificativa da eleição do tema também considera que a doutrina nacional, embora arrole o desafio de harmonizar a legislação tributária para o desenvolvimento do MERCOSUL, pouco avançou em relação a como concretizá-la. A discussão doutrinária costuma encerrar-se na possibilidade ou não de alterar a repartição de competências tributárias atribuídas aos entes da federação, tendo em vista que o nosso sistema tributário foi insculpido na Constituição Republicana, como reforço e consequência da opção pelo federalismo. Há um distanciamento em relação aos compromissos internacionais assumidos pelo país e uma compreensão parcial do fenômeno da regionalização que tanto instiga os estudiosos do direito internacional.

Há muita semelhança entre o momento que vivenciamos no âmbito do MERCOSUL e o ano de 1985 para a Comunidade Econômica Europeia: crise econômica, protecionismo, listas de mercadorias protegidas, europessimismo, sistemas tributários desarmônicos e tributação do consumo que não favorecia a livre concorrência.

\footnotetext{
${ }^{6}$ CASELLA, Paulo Borba. A integração econômica e seu tratamento constitucional. In: MERCOSUL: desafios a vencer. São Paulo: Conselho Brasileiro de Relações Internacionais (CBRI), 1994. p. 95.
} 
A modificação daquele cenário iniciou-se no seio da Comissão Europeia após a publicação do Livro Branco ${ }^{7}$, uma carta de intenções que continha duzentas e dezoito recomendações, em formato de súmulas, que deveriam ser observadas para a construção do mercado comum europeu.

Este documento, gentilmente cedido para esta pesquisa pelo Instituto Europeu, demonstra que os problemas identificados no velho continente assemelham-se, em grande parte, ao dilema enfrentado pela nossa doutrina no tocante à necessária modificação do sistema tributário brasileiro, fato que encoraja o estudo das soluções apresentadas pela experiência europeia.

A cientificidade da tese repousa na abordagem diferenciada do tema da harmonização da legislação tributária dos impostos indiretos, no âmbito do MERCOSUL, e tenciona contribuir para o avanço do processo de integração da América Latina; a originalidade destaca-se, com mais relevo, no estudo das espécies tributárias vigentes na República Bolivariana da Venezuela, ainda inexistente na doutrina nacional, para apurar se os tributos que alcançam o consumo de bens e serviços daquele país são passíveis de harmonização ou se representam mais um obstáculo a ser superado.

Ademais, pretende-se apresentar, sob os auspícios da teoria da regra-matriz da norma tributária, proposta pelo Professor Titular da Faculdade de Direito da USP Paulo de Barros Carvalho ${ }^{8}$, reflexões para a concretização da aproximação das legislações tributárias dos Estados partes, com o objetivo de contribuir para o avanço da disciplina e concretização dos objetivos traçados no Tratado de Assunção.

Por fim, esta tese insere-se no debate do novo papel do Estado ${ }^{9}$ frente aos desafios da internacionalização e da regionalização, processos que, bem conduzidos, poderão gerar benefícios para a sociedade dessas coletividades.

${ }^{7}$ COMMISSION OF THE EUROPEAN COMMUNITIES. Completing the internal market: White Paper from the Comission to the European Council (Milan, 28-29 June 1985).

${ }^{8}$ Segundo Rodrigo Medeiros Guardia: “É mérito de Paulo de Barros Carvalho ter reunido sob a denominação 'norma padrão' ou 'regra-matriz de incidência' a estrutura sintática mínima que se esconde em um juízo hipotético condicional e que permite que ele seja aceito pelo intérprete que o arquitetou como sendo uma mensagem jurídica com sentido completo. Em outros termos, regra-matriz é uma expressão que passou a ser utilizada pela doutrina em alusão ao esqueleto lógico-sintático indispensável à sustentação deôntica das significações que foram construídas e organizadas pelo intérprete a partir dos enunciados jurídicos ou textos de lei". (GUARDIA, Rodrigo Medeiros. A regra-matriz de incidência das normas jurídicas como diagrama semiótico. Cognitio-Estudos: Revista de Filosofia, São Paulo, CEP/PUC-SP, v. 8, n. 2, p. 108, jul./dez. 2011.

9 No ano de 1996, no painel de debates sobre o futuro da Europa promovido pela Universidade de Salamanca (Espanha), Jürgen Habermas, ao saudar os conferencistas, dentre eles, o emérito professor de direito tributário da Universidade de Colônia Klaus Tipke, afirmou que o progresso da Comunidade Europeia (CE) estava intimamente relacionado aos ajustes fiscais promovidos pelos países europeus. Tipke retribuiu o galanteio ao filósofo da Escola de Frankfurt e sentenciou: apenas o sonho de uma Europa unida havia sido 


\section{Delimitação do objeto e o seu desenvolvimento}

A tese tenciona demonstrar em quais aspectos o sistema tributário brasileiro representa um importante entrave ao projeto de integração iniciado após a assinatura do Tratado de Assunção pelos governos de Argentina, Brasil, Paraguai e Uruguai. ${ }^{10}$

Para alcançar os objetivos propostos, o tema a ser desenvolvido será estruturado em duas partes. A primeira, que compreende os Capítulos 1 e 2, apresenta o fenômeno da integração econômica após a Segunda Guerra Mundial, com o objetivo de demonstrar a evolução e os conflitos de interesses refletidos nesses tratados internacionais.

O primeiro capítulo ambiciona inserir o MERCOSUL no contexto da universalização da ideia de integração entre países, fenômeno que atinge todos os continentes. $^{11}$

A integração econômica regional, vista como um fenômeno complexo, dinâmico e com "múltiplas facetas"12, por um lado contrasta com os desígnios cosmopolitas da Organização das Nações Unidas (ONU) e multilaterais da Organização Mundial do Comércio (OMC) e, por outro, na síntese dos opostos da dialética hegeliana ${ }^{13}$, os mantêm vivos e os renovam. ${ }^{14}$

capaz de justificar o empenho e os sacrifícios constatados no processo de reforma do sistema tributário dos Estados membros da atual União Europeia. Esse diálogo, interdisciplinar, suscitou o tema desta tese.

${ }^{10}$ A Venezuela é membro pleno desde 12 de agosto de 2012, quando entrou em vigor o seu protocolo de adesão.

${ }^{11}$ AMARAL JÚNIOR, Alberto do. A solução de controvérsias na OMC. São Paulo: Atlas, 2008. p. 28.

12 CELLI JUNIOR, Umberto. Teoria geral da integração: em busca de um modelo alternativo. In: MERCADANTE, Araminta de Azevedo; CELLI JUNIOR, Umberto; ARAÚJO, Leandro Rocha de (Org.). Blocos econômicos e integração na América Latina, África e Ásia. Curitiba: Juruá, 2006. p. 19-37. O debate sobre o regionalismo internacional apresenta múltiplas facetas: política, econômica, ideológica, jurídica. Sob esse último ângulo, a questão central é a da oportunidade do regionalismo favorecer as instituições regionais e reforçar o corpus das normas da integração.

${ }^{13}$ Os dois contrários que engendram o devir (síntese) se reencontram fundidos, reconciliados. A filosofia hegeliana vê em toda parte tríades de teses, antítese e sínteses, nas quais a antítese representa a "negação" da tese, e a síntese constitui a unidade e, ao mesmo tempo, a certificação de ambas (ABBAGNANO, Nicola. Dizionario di filosofia. 2. ed. riv. e acres. Torino: Unione Tipografico Editrice Torinese (UTET), 1971. p. 318).

${ }^{14}$ No mesmo sentido: DINH, Nguyen Quoc; DAILLIER, Patrick; PELLET Alain. Droit international public. 4e éd. Paris: Librairie Générale de Droit et de Jurisprudence (LGDJ), 1992. Segundo os autores, a tendência para o regionalismo reforçou-se e generalizou-se na sequência de dois fenômenos maiores: a descolonização e as tentativas de integração política e econômica. O regionalismo já não é apenas uma reação a um ambiente internacional desfavorável. É também um fenômeno positivo que traduz solidariedades mais estreitas do que em nível universal. Dá origem a uma rede bastante densa de relações de cooperação e a mecanismos de controle vinculativos para os estados, permite o aparecimento de ordens jurídicas de tal modo específicas que exige um domínio de cooperação mais extenso do que se costuma vivenciar nas organizações internacionais mundiais, sem descurar da importância das ideias e das práticas gestadas nesse ambiente, que poderá desencadear progressos em nível mundial. 
Sob esse prisma, o regionalismo será retratado como uma resposta às novas necessidades dos países que buscam soluções para os problemas transnacionais ${ }^{15} \mathrm{e}$, à medida que propõe modelos mais avançados de integração, corrobora para a preservação da paz, da democracia e do Estado de direito; sempre a exigir a reformulação do avelhantado conceito de soberania, a mitigar os nacionalismos político-ideológicos e a desafiar a dogmática jurídica.

O estudo se inicia com o delineamento dos fatos históricos que motivaram a multiplicação de acordos comerciais regionais, a partir da segunda metade do século XX. É importante compreender o encadeamento dos eventos ${ }^{16}$ que impulsionaram o regionalismo, para inferir as suas dimensões e as suas consequências, mormente para os modelos de integração que seguem a desafiar o direito internacional contemporâneo, por pretenderem ultrapassar os arquétipos tradicionais de zonas de livre comércio e de união aduaneira. ${ }^{17}$

Como o mundo que se esfacelou no fim da década de 1980 foi aquele formado pelo impacto da Revolução Russa de $1917^{18}$, constata-se que a tônica das relações contemporâneas é de caráter prioritariamente econômico. Por essa razão, será dada ênfase à integração regional econômica.

Sem descurar que é papel do direito inquietar-se com o desenvolvimento e os novos paradigmas da integração, após enquadrar os modelos e as propostas que se apresentam, cuida esse capítulo também de discorrer sobre os desafios das novas instituições surgidas no âmbito do direito da integração e do direito comunitário.

Como o desenlace do processo de integração está intimamente relacionado à clareza dos objetivos propostos nos tratados internacionais e ao ofício das instituições idealizadas para o cumprimento deles, serão confrontadas as matrizes supranacional e intergovernamental, para assentar as diferenças que serão exploradas nos capítulos seguintes e apontar os obstáculos a serem transpostos pelo MERCOSUL, a partir da análise da experiência europeia de unificação.

\footnotetext{
${ }^{15}$ As sucessivas crises mundiais, o terrorismo internacional, problemas relacionados ao meio ambiente, entre outros assuntos. Ver interessante posição de Eve Rimoldi Landmann (Futuro de la integración en la nueva civilización. Revista de la Secretaría del Tribunal Permanente de Revisión, Asunción, año 1, n. 2, p. 113127, 2013).

${ }^{16}$ A globalização da economia, o fim da guerra fria, a descolonização da África e da Ásia, a expansão da democracia e da economia de mercado, entre outros.

${ }^{17}$ A zona de livre comércio, como forma menos complexa de integração, pressupõe a eliminação de tarifas e barreiras não tarifarias, sejam elas técnicas, fitossanitárias, quantitativas ou de qualquer natureza, que acarretem restrições ao comércio entre os Estados integrantes. A união aduaneira agrega ao modelo anterior a instituição de tarifa externa comum e o regime geral de origem, aplicáveis em toda a união alfandegária, em relação a importações procedentes de terceiros estados.

${ }^{18}$ HOBSBAWN, Eric J. Era dos extremos: o breve século XX: 1914-1991. Tradução de Marcos Santarrita. 2. ed., 30. reimpr. São Paulo: Companhia das Letras, 1995. p. 14.
} 
Ao cabo, buscar-se-á conceituar o "mercado comum"19, ambiente que consagra as quatro grandes liberdades ${ }^{20}$ e exige grau elevado de coordenação e harmonização de políticas econômicas e fiscais. Por óbvio, torna-se necessário apresentar os conceitos que se relacionam com o vocábulo "harmonizar".

Almeja-se, ainda, demonstrar que a harmonização das legislações tributárias, em especial as que atingem o consumo de bens e serviços, é um dos pilares da integração e da construção de um mercado comum - ambiente que consagra as grandes liberdades previstas nos tratados internacionais.

O segundo capítulo abarca a experiência de construção do mercado comum no âmbito da Comunidade Econômica Europeia, como requisito para alcançar a união econômica e monetária. Considerando que o MERCOSUL, em tese, almeja atingir o patamar de um mercado único, a experiência europeia não deve ser negligenciada. ${ }^{21}$

A pesquisa versa sobre a ideia de uma Europa unida construída sobre as cinzas da Segunda Guerra Mundial que, além de preservar a paz ${ }^{22}$, visou a restabelecer o crescimento econômico nos países arrasados pelos conflitos bélicos e a assegurar a capacidade de concorrer, em nível mundial, com outras economias.

Será dado relevo às instituições supranacionais que erigiram essa organização internacional dotada de direitos soberanos e sustentada por pilares singulares, que correspondem a uma ordem jurídica própria e reconhece o primado do direito comunitário sobre o direito nacional. ${ }^{23}$

${ }^{19}$ Segundo Maurin Almeida Falcão, o mercado comum não é apenas um mercado de trocas, mas uma área harmônica, onde podem ser implantadas políticas econômicas e sociais, favorecendo o equilíbrio, como objetivo essencial da integração regional (Mecanismos para facilitação do processo de integração econômica: a formação de zonas tributárias. Revista de Direito Internacional, Econômico e Tributário da Universidade Católica de Brasília, n. 3, p. 254-270, 2008).

${ }^{20}$ Mercado comum pressupõe a materialização das seguintes liberdades nas operações e prestações entre os Estados membros: livre trânsito de mercadorias, de pessoas, de bens e capitais.

21 "É fácil imaginar o impacto que essas liberdades terão sobre a legislação dos diferentes países que integrem um mercado comum, no plano quer do Direito Constitucional, quer no das relações privadas. O exemplo europeu, pelo que tem de extremo, deve ser examinado antes de avaliarmos o impacto do Tratado de Assunção no sistema jurídico Brasileiro.” (BAPTISTA, Luiz Olavo; MERCADANTE, Araminta de Azevedo; CASELlA, Paulo Borba (Orgs.). Mercosul: das negociações à implantação. São Paulo: LTr, 1994).

22 "Para alguém como eu, que viveu seus anos de amadurecimento sob um regime despótico e durante uma guerra que durou cinco longos anos, os problemas urgentes, com a queda do regime e o fim da guerra, eram sobretudo a democracia e a paz, ligados entre si por um mesmo intento: eliminar a violência como meio para resolver os conflitos, seja no interior de um mesmo Estado, seja nas relações entre Estados nacionais." (BOBBIO, Norberto. Diário de um século: autobiografia. Organização de Alberto Pappuzzi; tradução de Daniela Versiani. Rio de Janeiro: Campus, 1998. p. 208).

${ }^{23}$ Pode-se afirmar que a União goza de existência própria, caráter permanente, vontade distinta dos seus membros e autonomia de atuação (SOARES, Mário Lúcio Quintão. Mercosul: direitos humanos, globalização e soberania. 2. ed. rev., atual. ampl. Belo Horizonte: Del Rey, 1999). 
Em seguida, serão estudados os esforços empregados para a harmonização da legislação tributária, que assentaram as bases para erigir o mercado único, um processo ainda inacabado, marcado por avanços e fases de estagnação ${ }^{24}$. O mais bem sucedido exemplo de integração plurinacional enfrentou problemas pertinentes à conciliação dos interesses nacionais com aqueles de caráter supranacional, notadamente em relação à matéria fiscal.

Serão analisados os instrumentos normativos que possibilitaram a harmonização das legislações tributárias dos países europeus. O direito comunitário, supranacional, produziu um acervo notável que merece ser analisado.

Será constatado que o passo decisivo para o cumprimento do objetivo traçado no Tratado de Roma foi esquadrinhado pelo relatório denominado Neumark Report ${ }^{25}$, que condenou a tributação cumulativa e recomendou a abolição desses impostos em todos os Estados membros, além de evidenciar a necessária e progressiva harmonização das legislações tributárias vigentes no território europeu.

Com vagar, pretende-se demonstrar que o imposto geral sobre o consumo, baseado no modelo de gênese francesa e paternidade atribuída ao financista francês Maurice Lauré $^{26}$ corresponde ao exponente máximo da harmonização fiscal comunitária.

A União Europeia optou pelo imposto incidente sobre o valor acrescido (IVA), por ele atender aos anseios fiscais, ser economicamente viável e favorecer o desenvolvimento econômico, além de possibilitar que o ônus suportado pelos seus operadores fosse transferido ao consumidor final. Em suma: a exação corresponde aos anseios de generalidade e neutralidade que se requer nas transações de bens e prestações de serviços no espaço comunitário.

A principal conclusão que se pretende alcançar é que para se implementar as grandes liberdades ${ }^{27}$ no mercado comum europeu foi necessário harmonizar as legislações

24 A recessão econômica mundial do inicio da década de 80 trouxe uma onda de euro pessimismo e insegurança em relação ao mercado comum. No entanto, a esperança renasceu em 1985, quando foi publicado o "livro branco" que estabelecia um calendário para concluí-lo até $1^{\circ}$ de janeiro de 1993. Esse objetivo ficou consagrado no Ato Único Europeu, que foi assinado em fevereiro de 1986 e entrou em vigor em $1^{\text {o }}$ de julho de 1987.

${ }^{25}$ ARENDONK, H. P. A. M. van. Citizens and taxation in the EU: fifty years after the Neumark Report. EC Tax Review, Kluwer Law Online, v. 21, n. 3, p. 144-156, 2012.

${ }^{26}$ Maurice Lauré (1917-2001) é conhecido pelo aperfeiçoamento da taxe sur la valeur ajoutée (TVA) francesa, entre nós denominado imposto sobre o valor acrescido (IVA).

${ }^{27}$ Mercado comum pressupõe: livre trânsito de mercadorias, de pessoas, de bens e capitais. Segundo Umberto Celli Junior, "há ainda uma quinta e fundamental liberdade que deve vigorar no mercado comum: a livre concorrência. Na União Europeia, desde o tratado de Roma (1957) que se procura assegurar a inexistência de distorções ou restrições à livre concorrência. O controle e a aplicação das regras comunitárias de concorrência têm sido, de fato, fundamentais para a evolução daquele processo de 
tributárias, notadamente em relação aos impostos incidentes sobre o consumo e, para tanto, os países membros foram obrigados a adotar o mesmo modelo de tributação incidente sobre o consumo de bens e serviços.

A experiência legislativa que emergiu no território europeu, após a eleição do tributo que deveria alcançar o consumo, investigada sob o prisma dos obstáculos superados por aqueles países que possuíam um sistema tributário diverso do modelo exigido, é pouco explorada pela doutrina pátria, embora as questões que envolvam a tributação do consumo no Brasil estejam intimamente relacionadas à necessidade (ou não) da adoção do IVA no país, em substituição ao atual modelo de tributação.

Ao discorrer sobre as reformas dos sistemas tributários consumadas pela República Federal da Alemanha e República Portuguesa, pretende-se lançar luzes para os desafios a serem enfrentados pelos países latino-americanos no âmbito do MERCOSUL.

Esses países superaram as dificuldades decorrentes da extinção de tributos locais que alcançavam a circulação de riquezas e o desenrolar desse processo será investigado com o objetivo de avaliar quais medidas foram elaboradas para assegurar que essa importante fonte de recursos fosse devidamente compartilhada entre os entes políticos internos e se, decorridos quase cinquenta anos da eleição desse modelo de tributação, os resultados foram satisfatórios.

Por derradeiro, será destacado o papel da jurisprudência do Tribunal de Justiça da União Europeia ${ }^{28}$, que assentou relevantes princípios e garantias asseguradas ao cidadão contribuinte em relação à tributação do consumo de bens e serviços no território da União.

Após situar o contexto da pesquisa e as diretrizes que a encerra, a segunda parte, que abarca os Capítulos 3 a 6, versa sobre os desafios para alcançar a integração no âmbito do MERCOSUL.

Para tanto, o terceiro capítulo enfatiza os princípios, objetivos e compromissos assumidos no Tratado de Assunção para alcançar: (i) a eliminação de entraves para assegurar a livre circulação de bens, serviços e fatores produtivos; (ii) o estabelecimento de uma Tarifa Externa Comum; e (iii) a coordenação de uma política integratória, a fim de garantir condições adequadas de concorrência entre os países e fortalecer o processo de integração, mediante a harmonização das legislações pertinentes.

integração." (Teoria geral da integração: em busca de um modelo alternativo, in Blocos econômicos $e$ integração na América Latina, África e Ásia, cit., p. 33).

${ }^{28}$ O Tribunal de Justiça foi estabelecido pelo Tratado de Roma (1952), com a missão de garantir o respeito do direito comunitário na interpretação e na aplicação dos Tratados. A denominação Tribunal de Justiça da União Europeia foi adotada pelo Tratado de Lisboa (2007). 
Nessa perspectiva, faz-se mister realçar a sua estrutura institucional, criticar o modelo intergovernamental ${ }^{29}$ de tomada de decisões e a forma de incorporação do direito mercosulino nos ordenamentos jurídicos dos Estados partes.

Como o MERCOSUL foi erigido para atingir o estágio de um mercado comum, pressupõe-se que as quatro grandes liberdades não deverão encontrar barreiras de nenhuma natureza, especialmente as tributárias.

Nessa empreitada, pretende-se averiguar quais os avanços já foram registrados para harmonizar as legislações nas áreas pertinentes para lograr o fortalecimento do processo de integração.

Ao desenlace, serão apresentadas as considerações a respeito da necessidade de se iniciar o processo de efetivação do mercado comum no âmbito do MERCOSUL, pela harmonização das legislações tributárias que alcançam o consumo, como ocorreu na experiência europeia.

O quarto capítulo destina-se a perscrutar o sistema tributário ${ }^{30}$ dos nossos parceiros no MERCOSUL, com o objetivo de avaliar de que forma foi atribuído o poder de tributar, tanto nas Repúblicas Federativas da Argentina e da Venezuela, quanto nos Estados Unitários do Paraguai e do Uruguai.

A partir dessas distinções, visando à compreensão das espécies tributárias que alcançam o consumo de bens e serviços, serão apontados os critérios ${ }^{31}$ que compõem a norma jurídica de cada uma delas: (i) critério material (delineador do

\footnotetext{
29 “A ausência de estrutura institucional supranacional representa ao mesmo tempo escolha e risco para o futuro desse espaço economicamente integrado, tal como ora se apresenta, sobretudo a partir da consolidação da união aduaneira." (CASELLA, Paulo Borba. Mercosul: exigências e perspectivas: integração e consolidação de espaço econômico. São Paulo: LTr, 1996. p. 53). Há outros desafios, como relata Casella: "As dificuldades de tal empreitada são numerosas, sejam estas de ordem técnica como estrutural, de ordem política como cultural, de ordem econômica como social, de ordem monetária como financeira, aduaneira ou fiscal, como de harmonização legislativa, tendo em conta a evolução dos acontecimentos internacionais, em especial a consolidação de grandes espaços econômicos e a importância de lograr uma adequada inserção internacional para seus países, expressando que este processo de integração constitui uma resposta adequada a tais acontecimentos, representando novo avanço no espaço tendente ao desenvolvimento progressivo da integração da América que se quer Latina.” (Ibidem, p. 60).

${ }^{30}$ Segundo Paulo de Barros Carvalho, "o sistema aparece como objeto formado de porções que se vinculam debaixo de um princípio unitário ou como a composição de partes orientadas por um vetor comum. Onde houver um conjunto de elementos relacionados entre si e aglutinados perante uma referência determinada, teremos a noção fundamental de sistema" (Direito tributário: fundamentos jurídicos da incidência. 3. ed. rev. e atual. São Paulo: Saraiva, 2004. p. 43-44).

${ }^{31}$ Para alcançar os objetivos propostos nesta tese, será adotada a estrutura da norma jurídico-tributária proposta por Paulo de Barros Carvalho, que vê a norma dividida classicamente em duas partes: hipótese endonormativa e consequência endonormativa. "A estrutura normativa não está na lei, mas na proposição que o direito positivo projeta e que o jurista, utilizando seu equipamento lógico-dedutivo, descobre quando descreve o direito. A sua linguagem é a do dever-ser. A lei, os sistemas jurídicos são diretivos. Extrair o dever-ser (sollen) do ser (sein) é a função principal da Ciência do Direito". (COÊLHO, Sacha Calmon Navarro. Curso de direito tributário brasileiro. 8. ed. Rio de Janeiro: Forense, 2005. p. 457).
} 
comportamento/ação); (ii) critério temporal (condicionador da ação no tempo); (iii) critério espacial (identificador do espaço da ação); (iv) critério pessoal (delineador dos sujeitos ativo e passivo da relação); (v) critério quantitativo (quantificador do comportamento/ação). ${ }^{32}$

Concluída essa etapa, será possível identificar a similitude dos modelos adotados por todos os países que compõem o MERCOSUL, com exceção do Brasil, como se denotará no capítulo seguinte.

A pedra angular da integração proposta - a necessária harmonização das legislações tributárias dos Estados membros - será analisada sob a ótica da compatibilidade dos sistemas tributários, da repartição de competências e das espécies vigentes em cada país.

Será dada ênfase aos tributos indiretos ${ }^{33}$ que alcançam o consumo, por serem eles que possibilitam o primeiro passo rumo ao mercado comum.

A análise dos sistemas tributários dos países que integram o MERCOSUL permitirá concluir que, em relação aos tributos indiretos, o modelo adotado pela República Federativa do Brasil representa um entrave ao sonho mercosulino.

No Capítulo 5 será demonstrado que o Brasil não adotou um amplo tributo sobre o consumo de bens e serviços. No sistema constitucional tributário, norteado pelo federalismo, todos os entes políticos da federação possuem competência tributária para instituir e cobrar tributos sobre o consumo, inclusive os municípios. O grande tributo sobre o consumo foi repartido no seio da federação.

As espécies tributárias serão analisadas conforme o seu desenho normativo e será comprovado que o modelo de repartição de competência brasileiro é incompatível com os

32 CARVAlHO, Aurora Tomazini de. Curso de teoria geral do direito: o constructivismo lógico-semântico. 3. ed. São Paulo: Noeses, 2013. p. 593-594.

${ }^{33}$ Amílcar de Araújo Falcão já criticava, desde 1964, a velha e surrada classificação dos impostos em diretos e indiretos (de pouco préstimo científico). Não obstante, o próprio autor reconhece que nos textos internacionais há prevalência desta definição. Como não é o interesse deste trabalho discutir as teorias dos impostos in specie, foi utilizada, didaticamente, a expressão (Fato gerador da obrigação tributária. 6. ed. rev. e atual. Rio de Janeiro: Forense, 1994. p. 78). Segundo Sacha Calmon Navarro Coêlho, os impostos buscam no mundo jurídico eventos reveladores de fatos-signos de capacidade contributiva que os tornam fatos jurígenos (Becker). Grosso modo, as sociedades complexas do hodierno expõem à visitação do legislador - conforme Tipke e Lang - quatro eventos significativos de capacidade contributiva em torno dos quais é possível fazer incidir impostos, a saber: (i) a renda, nas suas diversas facetas de riqueza nova no momento em que é ganha e realizada (impostos sobre a renda); (ii) a renda já ganha e transformada nos vários tipos de patrimônio (aziendal, automobilístico, imobiliário, financeiro), a suscitar os impostos sobre o capital e o patrimônio; (iii) as transferências de capital patrimônio (os impostos sobre a transmissão de bens por atos inter vivos ou causa mortis); e (iv) a renda no momento em que é consumida na aquisição de bens e serviços, pelas pessoas físicas e jurídicas (impostos sobre o consumo ou indiretos, noutra terminologia). (Tributação indireta e regressividade. In: MACHADO, Hugo de Brito (Coord.). Tributação indireta no direito brasileiro. São Paulo: Malheiros, 2013. p. 396-400). 
espécimes que vigoram nos países que integram o MERCOSUL, por uma razão incontornável: não há, no Brasil, um imposto geral que alcança o consumo, mas tributos concorrentes e arrecadados por todos os entes da federação.

Agrava o cenário a crença de parte da doutrina nacional em relação às dificuldades políticas e econômicas internas que não possibilitam a inclusão do tema em um projeto de reforma tributária, embora a adoção do IVA no Brasil seja um tema recorrente nas discussões sobre a necessidade de uma reforma constitucional que promova a simplificação e a racionalização do nosso sistema tributário.

Sob esse prisma, diverge a doutrina pátria em relação às vantagens, condições e possibilidade de modificação da repartição de competências estabelecida na Carta de 1988, para concentrá-la ainda mais na União, ou se a opção mais adequada, e em sintonia com o princípio federativo, exige apenas o aperfeiçoamento do sistema atual.

A opção da República Federativa do Brasil em atribuir competência compartilhada aos entes da federação possui razões históricas e econômicas que devem ser respeitadas, entretanto o objetivo central dessa argumentação será demonstrar que essa escolha contribuiu para um cenário de incertezas e em nada corrobora para o aperfeiçoamento do Estado Democrático de Direito, que exige o respeito ao princípio da segurança jurídica (formal e material) e obriga a efetividade dos princípios constitucionais tributários, conforme nos ensina Torres. ${ }^{34}$

Para refutar a impressão de incompatibilidade do federalismo e a adoção de um tributo geral sobre o consumo - conciliável com o projeto de construção do MERCOSUL -, será explorado o atual cenário marcado pelo conflito de competências ${ }^{35}$, guerra fiscal ${ }^{36} \mathrm{e}$ flagrantes violações aos princípios constitucionais, notadamente o da não cumulatividade,

\footnotetext{
${ }^{34}$ A segurança jurídica concorre para o aperfeiçoamento permanente do Estado Democrático de Direito e, por conseguinte, para a efetividade do sistema constitucional tributário, na medida que tem por finalidade reduzir as incertezas decorrentes do ordenamento e preservar a confiança gerada sobre seu bom funcionamento, sem concessões para subjetivismos e tratamentos diferenciados, exceto nos casos autorizados pela constituição. Nesse sentido: TÔRRES, Heleno Taveira. Direito constitucional tributário e segurança jurídica: metódica da segurança jurídica do sistema constitucional tributário. 2. ed. rev., atual. e ampl. São Paulo: Revista dos Tribunais, 2012; Segundo Ávila, a segurança jurídica é um ideal normativo de primeira grandeza em qualquer ordenamento jurídico, especialmente no ordenamento pátrio. [...] $\mathrm{O}$ essencial é que a Constituição Brasileira, mais do que exigir a promoção do princípio da segurança jurídica, corporifica-o pela preocupação, do início ao fim, com os ideais de cognoscibilidade, de confiabilidade e de calculabilidade nomativas, tal é a ênfase que atribui à limitação do poder, inclusive e especialmente de tributar, e à garantia dos direitos fundamentais, notadamente no âmbito do Direito Tributário." (ÁVILA, Humberto. Segurança jurídica: entre permanência, mudança e realização do direito tributário. 2. ed. rev., atual. e ampl. São Paulo: Malheiros, 2012. p. 673).

${ }^{35}$ Dois ou mais sujeitos passivos exigem o mesmo tributo em bases territoriais distintas, ou tributos distintos, sobre o mesmo fato gerador, em casos não autorizados constitucionalmente.

${ }^{36}$ Concessão de benefícios fiscais concedidos pelo sujeito ativo da obrigação tributária que se traduzem em redução da carga tributária, com o objetivo de atrair contribuintes para o seu território.
} 
que causam incertezas, indefinições e um cenário de completa insegurança jurídica, quer no tocante ao plano interno, quer em relação ao plano internacional.

Nesse contexto, o que se observa é um enfraquecimento da federação e dos objetivos traçados pela Constituição da República Federativa do Brasil, razão pela qual comporta uma possível revisão do modelo adotado.

Ao demonstrar a latente incompatibilidade de harmonização, em decorrência da repartição da tributação do consumo no seio da nossa federação, verificar-se-á se a República Federativa do Brasil necessita reformar o seu sistema tributário, caso pretenda fazer avançar o MERCOSUL.

Pretende-se demonstrar ainda que a ausência da neutralidade plena do tributo onera o setor produtivo, reduz as chances de concorrência em um mercado globalizado e, por óbvio, inviabiliza o projeto de integração idealizado pelo Tratado de Assunção.

À guisa de conclusão, verificar-se-á que a divisão da tributação sobre o consumo em espécies distintas (concorrenciais) e a sua repartição entre os entes da federação representam um dos maiores entraves para o progresso do MERCOSUL.

Diante da ausência de instituições supranacionais, o real compromisso dos estados em promover, internamente, as necessárias modificações de suas legislações, para ajustálas ao desejo de integração, repercutirá no sucesso ou no fracasso do bloco.

Ante a necessária reforma do sistema tributário brasileiro, o capítulo final pretende estabelecer os alicerces e pressupostos para a harmonização das legislações tributárias dos países do Mercado Comum do Sul, ao identificar os critérios da norma tributária que deverão ser harmonizados.

Os desacertos cometidos nas fases de harmonização da tributação indireta, em solo europeu, poderão nortear as necessárias reflexões para dar um novo rumo ao nosso processo de integração regional. 
Primeira Parte

O MERCADO COMUM: UM DIVISOR DE ÁGUAS

\title{
CAPÍTULO 1 - OS ACORDOS REGIONAIS DE INTEGRAÇÃO
}

\author{
1.1 Os acordos comerciais regionais firmados a partir da segunda metade do século \\ XX
}

O término da Segunda Guerra Mundial suscitou a retomada do comércio internacional $^{37}$, mas foi o esfacelamento dos regimes formados pelo impacto da Revolução Russa e, consequentemente, a expansão dos regimes democráticos, que fomentaram a assinatura, sem precedentes, de tratados comerciais internacionais sinalados por forte viés integracionista $^{38}$. Promulgados à margem do multilateralismo ${ }^{39}$, visam à ampliação do mercado e máxima inserção dos seus membros no panorama internacional, podendo ainda abordar temas tão diversos como a preservação da paz, a proteção do meio ambiente e a defesa da democracia.

O fim da disputa ideológica travada no período que se convencionou chamar de guerra fria ${ }^{40}$ não foi, isoladamente, o único responsável por esse fenômeno. A consolidação

37 Interessante observar que, um ano antes do fim do conflito, foi proposta a criação da Organização Internacional do Comércio (OIC), destinada a regular as relações comerciais entre os países no pós-guerra. Essa organização deveria formar o tripé das instituições idealizadas pela Conferência de Bretton Woods (1944), que resultou na criação do FMI e do BIRD. A proposta não prosperou e o fracasso resultou na assinatura do GATT, que vigoraria a partir de 1948. Nesse sentido: FERRACIOLI, Paulo. Do GATT à OMC: a regulação do comércio internacional. Disponível em: <http://www.cepal.org/dmaah/noticias/paginas/9/28579/OMCna.pdf>. Acesso em: 02 out. 2014. Conclui-se que os projetos de integração regional receberam um reforço, na medida que fracassava a tentativa de conformação de um projeto verdadeiramente multilateral, que envolvesse a liberação real do comércio entre todos os países.

${ }^{38}$ Termo utilizado no sentido de busca pela integração econômica e política entre países.

${ }^{39} \mathrm{O}$ termo multilateralismo descreve o interesse da Organização Mundial do Comércio (OMC) em velar universalmente para que o comércio internacional se realize da maneira mais fluida, previsível e livre possível. Os acordos firmados no âmbito da OMC envolvendo todos os países são considerados multilaterais. Os demais são classificados, pela organização como acordos comerciais preferenciais (bilaterais ou regionais) ou acordos comerciais regionais. O dicionário de termos técnicos da OMC o define assim: "Multilateralism: an approach to the conduct of international trade based on cooperation, equal rights and obligations, non-discrimination and the participation as equals of many countries regardless of their size or share of international trade. This is the basis of the rules and principles embodied in treaties such as the Marrakesh Agreement Establishing the World Trade Organization and its components." (GOODE, Walter. Dictionary of trade policy terms. 4th ed. Cambridge, UK; New York, NY: Cambridge University Press, 2003. p. 115).

${ }^{40}$ Conflito de ordem ideológica travada entre os Estados Unidos da América e a extinta União Soviética no período de 1945 (fim da Segunda Guerra Mundial) e 1991(colapso da URSS), que abrangeu a ordem política, militar, tecnológica e econômica entre as duas nações, com reflexos em todos os continentes. A 
do modelo neoliberal de economia de mercado ${ }^{41}$ encontrou fértil terreno, propiciado pelos processos de descolonização da África e da Ásia, os esforços de reconstrução do continente europeu devastado pelas guerras mundiais, o recrudescimento da globalização da economia e o avanço das novas tecnologias para impulsionar o regionalismo ${ }^{42}$ e fomentar os modelos de integração, que seguem a desafiar o direito internacional contemporâneo, ao pretenderem suplantar os arquétipos dos clássicos acordos de livre comércio e de união aduaneira. $^{43}$

Fenômeno complexo, dinâmico e de múltiplas facetas ${ }^{44}$, as propostas de aproximação são sinaladas, quando menos, por: (i) eleição de problemas de importância recíproca; (ii) concessão de vantagens mútuas; (iii) certa identidade comum; (iv) valores básicos compatíveis; e (v) previsibilidade do comportamento dos seus membros ${ }^{45}$. Para além da cooperação entre países, exigem o adensamento de instituições capazes de dar vida aos desígnios de maior integração política, social e econômica e, não raro, o reconhecimento de um poder supranacional.

A sua importância igualmente reside no aumento da estreita solidariedade vivenciada pelos signatários, algo difícil de ser distinguido, por hora, universalmente. Por essa razão, há a expressa consagração de sua compatibilidade com os princípios da

expressão qualifica-se pela ausência de um conflito bélico direto entre os dois países, em razão do forte arsenal nuclear, com enorme poder de destruição.

${ }^{41}$ Ver: PANEBIANCO, Massimo. L’organizzazione internazionale regionale. In: BAPTISTA, Luiz Olavo; FONSECA, José Roberto Franco da (Coords.). O direito internacional no terceiro milênio: estudos em homenagem ao professor Vicente Marotta Rangel. São Paulo: LTr, 1998. p. 194-213.

42 Aquele que se contrapõe ao termo multilateralismo. O dicionário de termos técnicos da OMC o define assim: "Regionalism: actions by governments to liberalize or facilitate trade on a regional basis, sometimes through free-trade areas or customs unions." (GOODE, Walter. Dictionary of trade policy terms. 4th ed. Cambridge, UK; New York, NY: Cambridge University Press, 2003. p. 273). Segundo a OMC, o regionalismo corresponde a ações por parte dos governos para liberalizar o comércio em bases regionais, por vezes por meio de áreas de livre comércio ou em uniões aduaneiras. Para Jagdish Bhagwatti, regionalismo como redução preferencial de barreiras ao comércio entre um subconjunto de países que podem ser, mas não necessariamente, contíguos; no multilateralismo, a redução é indiscriminada (extensiva a todos os países). (BHAGWATI, Jagdish. Regionalism and multilateralism: an overview. In: DE MELO, Jaime; PANAGARIYA, Arvind (Eds.). New dimensions in regional integration. Cambridge: Cambridge University Press, 1996. p. 22).

${ }^{43}$ A zona de livre comércio pressupõe a eliminação de tarifas e barreiras que acarretem restrições ao comércio entre os Estados integrantes e a união aduaneira inclui a instituição de uma tarifa externa comum e o regime geral de origem, aplicáveis em toda a união alfandegária, em relação a importações procedentes de outros países que não compõem o acordo. Ambos serão estudados detalhadamente neste capítulo.

${ }^{44} \mathrm{O}$ debate sobre o regionalismo internacional apresenta múltiplas facetas: política, econômica, ideológica e jurídica. Para o direito, importa a oportunidade de reforço das instituições internacionais e a profusão de normas do acervo comunitário ou da integração. Pensam dessa forma Nguyen Quoc Dinh, Patrick Daillier e Alain Pellet (Droit international public. 4e éd. Paris: Librairie Générale de Droit et de Jurisprudence (LGDJ), 1992). Ver também: CELLI JUNIOR, Umberto, Teoria geral da integração: em busca de um modelo alternativo, in Blocos econômicos e integração na América Latina, África e Ásia, cit., p. 19-37.

${ }^{45}$ MATTOS, Adherbal Meira. Apresentação. In: CASELLA, Paulo Borba; LIQUIDATO, Vera Lúcia Viegas (Coords.). Direito da integração. São Paulo: Quartier Latin, 2006. p. 15. 
Organização das Nações Unidas (ONU) e da Organização Mundial do Comércio (OMC), conforme prevê o Capítulo VII da Carta das Nações Unidas ${ }^{46}$ e o artigo XXIV do GATT/OMC ${ }^{47}$. Sob o ponto de vista do mercado, embora o tratamento privilegiado dado aos países membros nas suas relações comerciais entre em contradição com a cláusula da nação mais favorecida ${ }^{48}$ - motor do princípio da não discriminação que edifica o multilateralismo ${ }^{49}$ - admite-se a sua existência, desde que não colida com os objetivos daquela organização.

Como visto, esses acordos internacionais podem prever maior ou menor grau de aproximação entre os países, ampliar as áreas de atuação conjunta ou, em raros casos, ultrapassar os aspectos econômicos e inserir novas dimensões e desafios. Em seu núcleo comum almejam reduzir os entraves aduaneiros, fiscais e não tarifários vinculados à circulação de mercadorias e serviços. Outros, mais ambiciosos, preveem a liberação da circulação das pessoas e de capitais. Dependendo, portanto, do grau de aproximação proposto, desponta uma clássica fórmula de cooperação entre Estados soberanos ou vislumbra-se uma lídima proposta de integração. ${ }^{50}$

46 A Carta das Nações Unidas foi assinada em 26 de junho de 1945, em São Francisco, ao término da Conferência das Nações Unidas, e entrou em vigor no dia 24 de outubro do mesmo ano. Os artigos referenciados são os 52 a 54. Por ora basta a reprodução do artigo 52.1, por ser suficiente para exemplificar o que se afirma: “Artigo 52. 1. Nada na presente Carta impede a existência de acordos ou de entidades regionais, destinadas a tratar dos assuntos relativos à manutenção da paz e da segurança internacionais que forem suscetíveis de uma ação regional, desde que tais acordos ou entidades regionais e suas atividades sejam compatíveis com os Propósitos e Princípios das Nações Unidas."

${ }^{47} \mathrm{O}$ artigo XXIV do GATT/OMC dispõe que o GATT não deverá impedir os acordos bilaterais ou regionais, desde que os impostos e as regras para o comércio não sejam mais restritivos que a incidência normal dos impostos e regras de comércio vivenciadas nos territórios membros antes da sua formação. Os acordos devem ser notificados para serem analisados sob a ótica do sistema multilateral. Para maiores reflexões sobre a problemática e abrangência do conteúdo do artigo, ver: Entendimento sobre o artigo XXIX, parte integrante dos acordos do GATT 1994, na estrutura normativa da OMC, no sítio próprio: <www.wto.org>. Acesso em: 05 set. 2014.

${ }^{48}$ A cláusula da nação mais favorecida estabelece que qualquer tratamento privilegiado concedido a qualquer país estende-se aos demais membros da OMC. O dicionário de termos técnicos da OMC o define assim: "Most-favoured-nation treatment: MFN. This is the rule, usually established through a trade agreement, that a country gives each of the trading partners with which it has concluded relevant agreements the besttreatment it gives to any of them in a given product." (GOODE, Walter. Dictionary of trade policy terms. 4th ed. Cambridge, UK; New York, NY: Cambridge University Press, 2003).

${ }^{49}$ Segundo a Comissão de Direito Internacional da ONU, o princípio da não discriminação é um princípio geral baseado na igualdade dos Estados quanto a sua soberania, enquanto que a cláusula da nação mais favorecida é um meio ou técnica para efetivar esta igualdade entre os Estados (NAKADA, Minoru. A OMC e regionalismo. São Paulo: Aduaneiras, 2002. p. 36).

${ }^{50}$ Para Vera Lúcia Viegas Liquidato, a distinção entre cooperação e integração é uma questão de grau, e não de modelo, com quem estamos inteiramente de acordo. Mais adiante, essa visão será retomada no estudo das instituições (intergovernamental ou supranacional) criadas a partir das propostas de integração ou cooperação internacionais (LIQUIDATO, Vera Lúcia Viegas. Teoria da harmonização jurídica: alguns esclarecimentos. Novos Estudos Jurídicos, v. 9, n. 3, p. 632, set./dez. 2004. Disponível em: <siaiweb06.univali.br/seer/index.php/nej/article/download/382/325>. Acesso em: 02 out. 2014). 
Os anseios contemporâneos de maior integração entre países foram gestados após se constatar que as noções e deformações alusivas ao Estado nação ${ }^{51}$ e o seu monopólio da decisão política (obra prima da tradição europeia e do racionalismo ocidental) haviam causado grandes males e destruição, especialmente em solo europeu. ${ }^{52}$

Essa busca por uma maior integração compeliu os Estados a: (i) repensar a forma de cooperação entre os países, fato que desaguou na necessária revisão do avelhantado conceito de soberania; (ii) redefinir o papel das instituições responsáveis para a criação e para o cumprimento dos objetivos traçados nos tratados internacionais; (iii) decidir de que forma o direito material produzido seria inserido e aplicado internamente nos países membros, cenário propício para a consagração do poder supranacional; e (iv) estabelecer quais as liberdades seriam asseguradas nesse novo ambiente.

A vontade manifestada nos tratados que pretendem edificar um mercado comum ou, ainda, estabelecer uma união econômica entre países ${ }^{53}$, representa uma proposta mais arrojada, por perseguirem a livre circulação de bens, serviços, pessoas e capitais, experiência que impõe a revisão de conceitos, regras e princípios jurídicos estabelecidos, bem como a formulação de outros novos.

Em particular, a garantia de livre circulação de pessoas ${ }^{54}$, para além das fronteiras do Estado, foi o componente novo que justificou a fortiori o desabrolhar do direito da integração e do direito comunitário. ${ }^{55}$

A possibilidade de estabelecer residência, eleger a universidade que pretende frequentar, exercer livremente a sua profissão, escolher onde adquirir mercadorias e

51 Termo utilizado para descrever a seguinte realidade: enquanto um Estado é uma entidade política e geopolítica, uma nação é uma unidade étnica e cultural. O termo "Estado nação" implica em uma situação onde os dois são coincidentes. O Estado nação afirma-se por meio de uma ideologia, uma estrutura jurídica, a capacidade de impor uma soberania, sobre um povo, num dado território com fronteiras, com uma moeda própria e forças armadas próprias.

${ }^{52} \mathrm{O}$ fascismo, em todas as suas versões, e as guerras mundiais que devastaram a Europa.

${ }^{53}$ Para a classificação dos tipos de integração, adotaremos a clássica divisão proposta pelo húngaro Béla Balassa (Teoria da integração econômica. Tradução de Maria Filipa Gonçalves e Maria Elsa Ferreira. Lisboa: Livraria Clássica Editora, 1982). Entretanto, será explicitado, oportunamente, que a necessária progressão dos graus de integração previstos em sua teoria não se configuram na prática, conforme amplamente defendido pela doutrina nacional.

${ }^{54}$ A defesa dessa liberdade não caminha em direção à busca de um modelo alternativo de integração, que supera a primazia do econômico, proposto científica e poeticamente por Celli Junior? Não seria essa uma razão suficiente para fazer emergir da estagnação o MERCOSUL? Poderia ser considerado como fundamento ético para eliminar os entraves ao projeto de integração latino-americana?

${ }^{55}$ Direito comunitário será utilizado para referenciar o direito da União Europeia, ou seja, o "cujo objeto de estudo é o ordenamento jurídico da União Europeia”. Direito da integração abrange as demais experiências integrativas, assim considerada como uma área nova do direito internacional, com objeto e métodos próprios. Ver as duas posições apresentadas por Paulo Borba Casella e Vera Lúcia Viegas Liquidato (CASELLA, Paulo Borba; LIQUIDADO, Vera Lúcia (Coords.). Direito da integração. São Paulo: Quartier Latin, 2006. p. 21 e 60, respectivamente). 
serviços, mesmo que em âmbito regional e delimitado, representa um passo rumo ao cosmopolitismo $^{56}$, à construção da cidade do mundo, que irá substituir o mundo das cidades, suas barreiras, limites e fronteiras, como sugere René-Jean Dupuy ${ }^{57}$. A integração, diversas vezes tentada pelo uso da força, seria agora fundada no acordo comum entre os Estados, por meio da constituição de um poder superior ao seu $^{58}$, em benefício da coletividade. Afinal - disse Bobbio - por trás dos interesses dos Estados “está a sociedade aberta como aspiração àquela sociedade capaz de romper o espírito exclusivista de cada grupo, e de fazer emergir das trevas sociais o homem, o singular, a pessoa em sua dignidade e em sua inviolabilidade". 59

Por fim, mas não menos relevante, reputa-se que o fenômeno da integração ${ }^{60}$ é uma resposta adequada às novas necessidades dos países que buscam soluções para os problemas transnacionais e, à medida que propõe modelos mais avançados de integração, corrobora a preservação da paz ${ }^{61}$, da democracia e do Estado de direito; sempre a mitigar os nacionalismos políticos-ideológicos e a desafiar a dogmática jurídica.

A incitação proposta é justamente investigar o universo da integração entre países que pretendem erigir um mercado comum, assim compreendido como a primeira proposta

${ }^{56}$ Embora também faça emergir um novo problema: o da inclusão "do outro", do "extracomunitário", aquele que se encontra à margem do processo de integração.

${ }^{57}$ DUPUY, René-Jean. $O$ direito internacional. Tradução de Clotilde Cruz. Coimbra: Almedina, 1993. p. 7.

58 "O exercício disperso das funções sociais deveria ser substituído por uma determinada concentração de poderes, ela própria mais ou menos desenvolvida segundo o grau de solidariedade comprovado pelos Estados associados. Passaríamos assim do mundo das cidades à cidade do mundo. Desse modo, realizar-seia não a unificação, como os grandes conquistadores tentaram em vão impor, mas a união, fundada no acordo comum entre Estados, para instituir uma autoridade superior à sua." (DUPUY, René-Jean. $O$ direito internacional. Tradução de Clotilde Cruz. Coimbra: Almedina, 1993. p. 7).

59 BOBBIO, Norberto. O tempo da memória: de senectute e outros escritos autobiográficos. São Paulo: Campus, 1997.

${ }^{60}$ Há vozes discordantes em relação a essa afirmativa. Veja-se, por exemplo, a posição Roberto Luiz Silva que, ao discorrer sobre a nova ordem internacional, aponta para o declínio do multilateralismo e afirma que o livre comércio realiza-se, principalmente, intrablocos e o protecionismo vigora interblocos, o que tem levado a um constante clima de guerras comerciais quando esses blocos disputam novos mercados. Segundo o autor, "o capitalismo hegemônico com a ruína do socialismo real, ingressou na etapa de sua total euforia triunfalista, sob o rótulo de neoliberalismo. Tais são os nossos tempos de palavras perfumadas: reengenharia, privatização, economia de mercado, modernidade e - metáfora do imperialismoglobalização. A informação mundializada de nossos dias não é exatamente troca: é a sutil imposição da hegemonia ideológica das elites. Em resposta a esse fenômeno [...] temos o surgimento de blocos regionais por meio da integração dos estados, na tentativa de fortalecer seu poder negociador dentro da sociedade internacional" (SILVA, Roberto Luiz. Globalização e regionalismo no cenário da nova ordem internacional. Revista da Faculdade de Direito da UFMG, n. 55, p. 141-166, jul./dez. 2009).

${ }^{61}$ Após atravessar sérias e sucessivas crises econômicas, a União Europeia recebeu, em 2012, o prêmio Nobel da Paz como reforço e reconhecimento dos esforços pela preservação da paz na Europa. Em seu discurso de agradecimento, Herman Van Rompuy, presidente do Conselho Europeu e José Manuel Durão Barroso, presidente da Comissão Europeia, proclamaram: "Em tempos de incerteza, o dia de hoje recorda aos povos da Europa e do resto do mundo o propósito fundamental da União: promover a fraternidade entre as nações europeias, agora e no futuro." (VAN ROMPUY, Herman. Da guerra à paz: uma história europeia. Discurso de aceitação do Prêmio Nobel da Paz atribuído à União Europeia/Oslo, 10 dezembro 2012. Disponível em: <europa.eu/rapid/press-release_SPEECH-12-930_pt.htm>. Acesso em: 02 out. 2014). 
a incluir, no reino das liberdades que os tratados internacionais planteiam assegurar, a livre circulação de pessoas, enfocando o seu aspecto jurídico ${ }^{62}$, nomeadamente a necessária harmonização das legislações tributárias dos países integrantes, como requisito mínimo para a sua concretização.

\subsection{Classificação dos modelos de integração}

Ao firmarem um tratado internacional de comércio, os países ${ }^{63}$ impingem o modelo de integração que pretendem alcançar; entretanto, entre a ideia proposta e a efetiva realização do desejo traçado, concorrem a clareza dos objetivos e a estrutura institucional que deverá erigir o novo ordenamento jurídico, fundado, em grande parte, na harmonização das normas relacionadas aos temas pertinentes ao acordo.

A clássica formulação de Béla Balassa ${ }^{64}$, criticada pela doutrina por descrever uma progressão natural de fases de integração ${ }^{65}$, será adotada para classificar, de modo didático e analítico, os modelos de integração vigentes. Revisada à luz das exceções ao princípio da não discriminação previstas no sistema multilateral do comércio ${ }^{66}$, a classificação proposta sopesa as distintas formalidades exigidas para a notificação dos modelos de integração nos quadros da OMC. ${ }^{67}$

62 Para Paulo Borba Casella, " o fenômeno da integração passa a integrar inexoravelmente os estudos de direito internacional, em suas mais variadas áreas". Na medida que [...] "as fronteiras entre os Estados tornam-se cada vez mais tênues", [...] "torna-se crescente a necessidade de estudar esses fenômenos sob o ponto de vista do direito da integração, como vertente específica do direito internacional". Pela natureza intrínseca do fenômeno, justamente será na junção de enfoques jurídico e econômico que se poderá melhor situar a confluência de interesses acadêmicos e profissionais, relacionados ao direito da integração". (CASELlA, Paulo Borba; LIQUIDADO, Vera Lúcia (Coords.), Direito da integração, cit., p. 21). O debate sobre a integração, sob o ponto de vista jurídico, permite desenvolver um laboratório de ideias e de práticas e, graças a essa antecipação experimental, permitir novos progressos em nível mundial. Pensam dessa forma: DINH, Nguyen Quoc; DAILLIER, Patrick; PELLET, Alain. Droit international public. 4e éd. Paris: Librairie Générale de Droit et de Jurisprudence (LGDJ), 1992. p. 67-68.

${ }^{63} \mathrm{Ou}$ agrupamento de países que possuem personalidade jurídica internacional como o MERCOSUL e a União Europeia.

${ }^{64}$ BALASSA, Béla. Teoria da integração económica. Teoria da integração econômica. Tradução de Maria Filipa Gonçalves e Maria Elsa Ferreira. 3. ed. Lisboa: Clássica Editora, 1982. O autor descreve cinco fases progressivas de integração econômica: 1. Zona de Livre Comércio; 2. União Aduaneira; 3. Mercado Comum; 4. União Econômica; e 5. Integração Econômica Total.

${ }^{65}$ A teoria de Balassa apresenta uma classificação ordenada de os processos sucessivos, em que cada avanço elimina a etapa anterior. Reconhece-se que alguns tratados objetivam apenas concretizar um modelo, sem demonstrar nenhum interesse em progredir naturalmente para tipos mais avançados. Ademais, os modelos convivem harmonicamente em um mesmo território aduaneiro, ou seja, no mesmo ambiente de um mercado comum, coexiste o conceito de união aduaneira. Apesar dessas críticas, é cediço que a doutrina mundial utiliza a mesma classificação (BALASSA, Béla. Teoria da integração económica. Tradução de Maria Filipa Gonçalves e Maria Elsa Ferreira. 3. ed. Lisboa: Clássica Editora, 1982).

${ }^{66}$ Artigos IX a XIII e XIV do GATT/OMC.

67 Os acordos comerciais preferenciais deverão observar, para notificação à OMC, o que estabelece o documento Transparency mechanism for preferential trade arrangements - General Council Decision of 14 


\section{(i) Zona de Livre Comércio (ZLC)}

$\mathrm{O}$ artigo XXIV do GATT/OMC define a ZLC como "um grupo de dois ou mais territórios aduaneiros entre os quais são eliminados os direitos alfandegários e as demais regulamentações comerciais restritivas, relativamente ao essencial dos intercâmbios comerciais dos produtos originários dos territórios constitutivos dessa zona de livre comércio".

Pela definição proposta e análise dos principais acordos registrados na OMC, podemos compreender que esses tratados internacionais ${ }^{68}$, objetivam criar uma área (zona) de livre comércio ${ }^{69}$, que abarca as seguintes características:

a) Delimitação do espaço em que será aplicado o tratamento preferencial: a

ZLC não se confunde com o somatório dos territórios dos países membros porque é formada pelo conjunto dos territórios aduaneiros ${ }^{70}$, conceito legal definido pelas partes que a compõem. Para um acordo firmado entre o MERCOSUL e a União Europeia, por exemplo, deve ser observado que o território aduaneiro do MERCOSUL compreende os territórios dos países integrantes, entretanto o território aduaneiro da União Europeia não se confunde com o território dos países que a formam ${ }^{71}$. Embora Ceuta pertença ao

December 2010 World Trade Organization: WT/L/806 16 December 2010 (10-6784). Os demais acordos denominados regionais deverão observar o disposto no documento Transparency mechanism for regional trade agreements - Decision of 14 December 2006. World Trade Organization WT/1/671 18 December 2006 (06-6056).

$68 \mathrm{O}$ dicionário de termos técnicos da OMC o define assim: "Free-trade agreement: a contractual arrangement between two or more countries under which they give each other preferential market access, usually called free trade. In practice, free-trade agreements tend to allow for all sorts of exceptions, many of them temporary, to cover sensitive products. In some cases, free trade is no more than a longer-term aim, or the agreement represents a form of managed trade liberalization." (GOODE, Walter. Dictionary of trade policy terms. 4th ed. Cambridge, UK: New York, NY: Cambridge University Press, 2003).

${ }^{69} \mathrm{O}$ dicionário de termos técnicos da OMC o define assim: "Free-trade area: a group of two or more countries or economies, customs territories in technical language, that have eliminated tariff and all or most non-tariff measures affecting trade among themselves. Participating countries usually continue to apply their existing tariffs on external goods." (GOODE, Walter. Dictionary of trade policy terms. 4th ed. Cambridge, UK: New York, NY: Cambridge University Press, 2003).

${ }^{70} \mathrm{O}$ território aduaneiro é o espaço onde a autoridade aduaneira de um país atua, controlando as operações de comércio exterior (importação e exportação). Segundo o regulamento aduaneiro do Brasil, o território aduaneiro abrange todo o território nacional e é dividido em duas partes: a zona primária (portos, aeroportos e pontos de fronteira alfandegados) e a zona secundária (restante do território, incluindo o espaço aéreo e as águas territoriais).

${ }^{71} \mathrm{O}$ território aduaneiro do MERCOSUL compreende: a) o território da República Argentina; b) o território da República Federativa do Brasil; c) o território da República do Paraguai; d) o território da República Oriental do Uruguai; e e) o território de qualquer Estado que se torne parte integrante do mesmo. Já o território da União Europeia compreende o território dos Estados membros, com as seguintes exceções: a) em relação ao território da República Federal da Alemanha: Ilha Helgoland e território de Büsingen (Tratado de 23 de novembro de 1964 entre a República Federal da Alemanha e a Confederação Helvética); b) ao Reino de Espanha: Ceuta e Melilha; c) França: Nova Caledônia, Mayotte, São Pedro e Miquelon, Ilhas Wallis e Futuna, Polinésia Francesa e terras austrais e antárcticas francesas, d) República Italiana: municípios de Livigno e Campione d'Italia e as águas nacionais do Lago de Lugano que se encontram entre a margem e a fronteira política da área situada entre Ponte Tresa e Porto Ceresio. Ao inverso, inclui: a) 
território do Reino da Espanha, não faz parte do território aduaneiro desse país, não compondo, portanto, a zona de livre comércio.

b) Discriminação das mercadorias ou serviços abrangidos pelo acordo: a ZLC não estabelece a liberdade plena de circulação de mercadorias ou dos serviços, assim definida como um princípio que deva alcançar a generalidade deles, indiscriminadamente. Ao contrário, o acordo estabelece, mediante um rol indicativo, quais estariam abrangidos pelas reduções ou eliminações de entraves à importação.

Neste quesito, esse acordo poderá ser classificado como recíproco, quando todas as hipóteses eleitas se aplicarem, de forma idêntica, a todos os Estados membros. Havendo eleição distinta em razão da procedência ou do destino das mercadorias ou dos serviços, ou ainda ausência de reciprocidade, serão classificados como áreas de livre comércio não recíprocas ou acordos de alcance parcial. A SPARTECA $^{72}$ e a Associação Latinoamericana de Integração (ALADI) ${ }^{73}$ representam, respectivamente, essas categorias.

É relevante destacar que os acordos de livre comércio não recíprocos distinguemse dos acordos preferenciais de comércio, porque estes, embora também estabeleçam preferências comerciais unilaterais (não recíprocas), o fazem cumprindo requisitos e formalidades distintos previstos nas exceções fundadas nos artigos IX a XIII do GATT/OMC. A correta diferenciação tem relevância para a notificação do acordo segundo o mecanismo de transparência da OMC. Os acordos preferenciais de comércio estão sujeitos às regras simplificadas estabelecidas na Decisão do Conselho Geral de 14 de

França: o território do Principado do Mônaco, conforme definido na Convenção Aduaneira assinada em Paris, em 18 de maio de 1963; b) Chipre: o território das zonas de soberania do Reino Unido de Akrotiri e Dhekelia, conforme definido no Tratado relativo à Fundação da República de Chipre, assinado em Nicósia, em 16 de agosto de 1960. O Regulamento (CE) n. 450/2008 do Parlamento Europeu e do Conselho, de 23 de abril de 2008, estabelece o Código Aduaneiro Comunitário. O artigo $3^{\circ}$ define o território aduaneiro.

72 SPARTECA: "South Pacific Regional Trade and Economic Cooperation Agreement. This Agreement, which entered into force on 1 January 1981, gives countries located in the South Pacific preferential nonreciprocal access to Australia and New Zealand. Access for sugar to the Australian market is excluded." (GOODE, Walter. Dictionary of trade policy terms. 4th ed. Cambridge, UK: New York, NY: Cambridge University Press, 2003).

${ }^{73}$ A ALADI é o maior grupo que almeja uma integração da América Latina. Atualmente é formada por treze países membros: Argentina, Bolívia, Brasil, Chile, Colômbia, Cuba, Equador, México, Panamá, Paraguai, Peru, Uruguai e Venezuela. O Tratado de Montevidéu 1980 (TM80), estatuto fundante, foi assinado em 12 de agosto de 1980, estabelecendo os seguintes princípios gerais: pluralismo em matéria política e econômica; convergência progressiva de ações parciais para a criação de um mercado comum latinoamericano; tratamentos diferenciais com base no nível de desenvolvimento dos países membros; e multiplicidade nas formas de concertação de instrumentos comerciais. O seu artigo $3^{\circ}$ prevê a convergência, que se traduz na multilateralização progressiva dos acordos de alcance parcial, por meio de negociações periódicas entre os países membros, como meta à constituição do mercado comum. Em nada avançou nesse propósito. 
dezembro de 2010, catalogada sob o registro WT/L/806 - Transparency Mechanism For Preferential Trade Arrangements. General Council Decision of 14 December $2010 .^{74}$

c) Reduções ou eliminações de entraves à importação almejadas: no tocante à eliminação dos direitos alfandegários e demais regulamentações comerciais restritivas, os signatários são livres para identificá-las, impor limites, dispor sobre cotas, redução ou eliminação dos impostos aduaneiros e outros encargos. Não há a obrigatoriedade de se consagrar a livre movimentação de mercadorias ou serviços, no sentido de alcançar a sua generalidade ou a completa eliminação dos entraves.

\section{d) Condições para o reconhecimento dos produtos ou dos serviços autorizados} a circular nesse espaço singular (usualmente identificado por um certificado de origem): por último, devem as partes estabelecer os requisitos para a identificação dos produtos e serviços que poderão circular livremente. As regras para identificar a origem dos produtos costumam levar em conta não apenas a exigência de fabricação do bem no território dos membros, mas também um percentual mínimo de conteúdo nacional, calculado mediante o consumo de matérias primas, produtos intermediários e mão de obra locais.

Após constatar a especificidades que permeiam os tratados de livre comércio, classificados pela doutrina nacional como a forma mais simples de integração, percebe-se que há a exigência de uma aproximação estreita entre os países, exigindo, por exemplo, uma harmonização das legislações que terão o condão de classificar, de forma inequívoca, as mercadorias e/ou os serviços que circulam nesse espaço singular (a adoção de uma nomenclatura comum para os bens e serviços).

Além das experiências citadas acima, o NAFTA ${ }^{75}$ é um exemplo de como os acordos de livre comércio podem evoluir ${ }^{76}$ e exigir cada vez mais sofisticação das

\footnotetext{
${ }^{74}$ A União Europeia adotou preferências comerciais com o Paquistão em relação a 75 produtos importantes na agenda de exportação do país, concedendo para 49 deles a redução completa dos direitos tarifários e para 26 o estabelecimento de uma cota de reduções significativa. O acordo vigorou de 15 de novembro de 2012 a 31 de dezembro de 2013. A justificativa para essa concessão foi a forte chuva das monções nos meses de julho e agosto de 2010, que atingiram importantes regiões do país, afetando vinte milhões de pessoas. A medida foi adotada juntamente à doação de 423 milhões de euros como ajuda de emergência. $\mathrm{O}$ texto do acordo foi notificado ao GATT/OMC em 18 de novembro de 2010 e notificado em 15 de janeiro de 2013, pelo mecanismo de transparência para os acordos comerciais preferenciais.

${ }^{75}$ NAFTA: Acordo Norte-americano de Livre Comércio. Seus membros são Canadá, Estados Unidos e México. O tratado é extremamente longo, complexo, abrange mercadorias e serviços e objetiva eliminar as barreiras ao comércio, promover a concorrência leal, a proteção adequada e eficaz dos direitos de propriedade intelectual, procedimentos eficazes de resolução de litígios e fornecer um quadro para aprofundar a cooperação trilateral, regional e multilateral. Entrou em vigor em $1^{\circ}$ de janeiro de 1994.

${ }^{76}$ No sentido de se tornar mais abrangente em relação à livre circulação de mercadorias e serviços. Bem diferente de evoluir para atingir um mercado comum, como pensava Béla Balassa, em sua teoria econômica, porque nem de longe pretende alcançar a livre circulação de pessoas. As fronteiras americanas
} 
instituições criadas pelo objetivo comum, contrariando a surrada distinção entre atos de cooperação e de integração entre países. ${ }^{77}$

\section{(ii) União Aduaneira (UA)}

Quando dois ou mais territórios aduaneiros, além de eliminar os direitos alfandegários e demais regulamentações comerciais restritivas ao comércio, decidirem praticar uma tarifa externa comum com terceiros países nas importações de mercadorias, será possível classificar esse tratado como instituidor de uma união aduaneira (UA). ${ }^{78}$

A definição acima, proposta pela $\mathrm{OMC}$, talvez não alcance a dimensão das uniões aduaneiras, principalmente se observados os avanços alcançados pela união dos países europeus neste setor.

As uniões aduaneiras possuem inspiração na Zollverein $^{79}$, fundada sob a liderança da Prússia, em 1834, por meio da unificação de várias uniões aduaneiras locais. No ano de 1871, foi incluída no império alemão recém-formado e garantiu grande parte do progresso econômico registrado na região, na primeira metade do século XIX.

estão cada vez mais maciças, como relata a doutora em Ciências Sociais pela Unicamp e professora do Centro de Ciências Humanas e da Educação da Universidade do Estado de Santa Catarina (FAED/UDESC) Gláucia de Oliveira Assis (The Mexico-United States border: between the dream and the nightmare: the experiences of emigrants/immigrants in non-authorized trips in the global world. Cadernos Pagu, Campinas, SP, Unicamp, v. 31, p. 219-250, 2008).

77 Como já previsto por Vera Lúcia Viegas Liquidato: “É muito simplório estabelecer uma linha divisória radical, entre a cooperação (área de preferência tarifária, zona de livre comércio, zona de união aduaneira) e, a integração (zona de mercado comum, zona de união política e monetária e de defesa externa comum). Mesmo nos casos em que ainda não se estabeleceu uma união aduaneira completa (cooperação), podem já estar presentes alguns elementos preparatórios do terreno de um mercado comum (integração)." (Teoria da harmonização jurídica: alguns esclarecimentos. Novos Estudos Jurídicos, v. 9, n. 3, p. 632, set./dez. 2004. Disponível em: <siaiweb06.univali.br/seer/index.php/nej/article/download/382/325>. Acesso em: 02 out. 2014). Concordamos com esse posicionamento, inclusive em relação à zona de livre comércio, no cenário atual da integração.

78 "Customs union: an area consisting of two or more individual economies or customs territories which remove all tariffs and sometimes broader trade impediments between them. The members making up the area then apply a common external tariff." (GOODE, Walter. Dictionary of trade policy terms. 4th ed. Cambridge, UK: New York, NY: Cambridge University Press, 2003). Nguyen Quoc Dinh, Patrick Daillier e Alain Pellet acrescentam, à supressão dos obstáculos aduaneiros nas trocas mútuas dos Estados membros, uma unificação aduaneira e da regulamentação das trocas comerciais com os países terceiros, conforme o artigo XXIV do GATT. Os territórios aduaneiros nacionais fundem-se num território aduaneiro único, como o que se concretizou em 1968 nas comunidades europeias (DINH, Nguyen Quoc; DAILLIER, Patrick; PELLET, Alain. Droit international public. 4e éd. Paris: Librairie Générale de Droit et de Jurisprudence (LGDJ), 1992. p. 950).

79 Zollverein: "Established under Prussian leadership in 1834 through the unification of several local customs unions. Its growth continued through the adhesion of other German states until 1871 when it was subsumed in the newly formed German Empire. The Zollverein is given credit for much of Germany's economic progress in the first half of the nineteenth century. However, as its early years coincided with the industrial revolution in Germany, its exact contribution to economic development, though clearly substantial, is difficult to assess." (GOODE, Walter. Dictionary of trade policy terms. 4th ed. Cambridge, UK: New York, NY: Cambridge University Press, 2003). 
A ideia foi ressuscitada e influenciou a criação da Benelux ${ }^{80}$, considerada a primeira união aduaneira realizada em solo europeu na primeira metade do século $\mathrm{XX}{ }^{81}$

A experiência europeia demonstrou que a UA não pode ser completamente concretizada sem que seja promovida uma harmonização progressiva das regulamentações comerciais relativas à circulação de mercadorias, o que requer uma transferência de competências para a negociação de acordos internacionais em matéria comercial (abdicação de prerrogativas de soberania), como identificado por Pellet e Celli Junior. ${ }^{82}$

Por essas razões, para ser considerada uma UA perfeita, deverão ser identificados os seguintes elementos no tratado internacional fundante:

a) Liberdade de circulação de mercadorias: o comércio de mercadorias deverá ser praticado livremente, não encontrando barreiras tarifárias ou não tarifárias. Exige, dessa forma, liberdade plena à circulação de mercadorias.

Esse conceito foi reforçado e difundido como modelo pela farta jurisprudência do tribunal supranacional europeu. O Tratado da Comunidade Econômica Europeia (CEE), no artigo $9^{\circ}$, havia estabelecido que a comunidade se basearia em uma união aduaneira para a totalidade dos intercâmbios de mercadoria, por meio da proibição, entre os Estados membros, dos direitos aduaneiros de importação e exportação e de quaisquer encargos de efeito equivalente. Em razão da vagueza da expressão, o Tribunal de Justiça da CEE proferiu o primeiro acórdão sobre o tema, que passou a ser a referência para todos os demais subsequentes.

O acórdão de $1^{\text {o }}$ de julho de 1969 dos Processos 2/69 e 3/69 estabeleceu que o conceito de encargo de efeito equivalente previsto no Tratado CEE abrange qualquer encargo pecuniário que seja aplicado devido à passagem da fronteira das mercadorias que circulam no interior da Comunidade, desde que tal imposição não seja admitida por disposições específicas do Tratado ${ }^{83}$. Dessa forma, houve a confirmação da necessidade de

${ }^{80}$ O Tratado de criação do Benelux (Union Économique Benelux) foi assinado pela Bélgica, Países Baixos e Luxemburgo, considerado um dos pilares da União Europeia.

${ }^{81}$ Nesse sentido: ALMEIDA, Elizabeth Accioly Pinto de. Mercosul e União Européia: estrutura jurídicoinstitucional. 4. ed. atual. Curitiba: Juruá, 2010. p. 26; e CUNHA, Paulo Pitta e. Estudos de economia, política e direito comunitários. Lisboa: Imprensa Nacional - Casa da Moeda, 1993. p. 101.

${ }^{82}$ DINH, Nguyen Quoc; DAILLIER, Patrick; PELLET, Alain. Droit international public. 4e éd. Paris: Librairie Générale de Droit et de Jurisprudence (LGDJ), 1992. p. 408; MERCADANTE, Araminta de Azevedo; CELlI JUNIOR, Umberto; ARAÚJO, Leandro Rocha de (Orgs.). Blocos econômicos e integração na América Latina, África e Ásia. Curitiba: Juruá, 2006. v. 1.

83 ARRÊT DU 1-7-1969 - AFFAIRES JOINTES 2 ET 3-69. "LA COUR, statuant sur les questions à elle soumises par le juge de paix du 2e canton d'Anvers, conformément au jugement rendu par cette juridiction le 24 décembre 1968, dit pour droit :1) La notion de taxe d'effet équivalent visée aux articles 9 et 12 dutraité C.E.E. comprend toute charge pécuniaire, autre qu'un droit de douane proprement dit, frappant en 
eliminação das barreiras fiscais, técnicas, aduaneiras e regulamentares, e dos regimes de cotas de importação.

b) Harmonização em relação à classificação das mercadorias: haverá a harmonização das classificações de mercadorias, para que haja a possibilidade de adoção de uma tarifa externa comum a ser aplicada no comércio com terceiros países. Nesse sentido, será necessário harmonizar a linguagem técnica utilizada para essa classificação, para que seja aplicada a mesma carga de direitos aduaneiros para os bens que ingressarem no território da união aduaneira. Percebe-se a necessidade de adoção de uma política tarifária comum em amplo sentido e o estabelecimento de legislação aduaneira e política comercial comuns.

O MERCOSUL caminha para superar esta fase de integração. Embora já tenha sido adotada a Nomenclatura Comum do MERCOSUL/Sistema Harmonizado de Designação e Codificação de Mercadorias (NCM/SH) e definidas as alíquotas para o comércio com países terceiros, os quatro países fundantes e a Venezuela mantêm exceções para produtos que não são importados com a mesma carga de tributação.

A doutrina nacional passou a identificar o MERCOSUL, pelos motivos expostos, como uma união aduaneira imperfeita.

\section{(iii) Mercado Comum}

Para a OMC, o mercado comum $^{84}$ corresponde a uma união aduaneira mais desenvolvida, por incorporar à liberdade de circulação de mercadorias a livre movimentação dos fatores de produção: o trabalho, os serviços e o capital.

Nada obstante, os tratados internacionais que propõem edificar um mercado comum vão além e consagram as quatro grandes liberdades ${ }^{85}$ em seus territórios: a livre circulação de mercadorias; a liberdade de movimentação de pessoas; a livre prestação serviços; e a liberdade de circulação de capitais.

raison du franchissementde la frontière les marchandises circulant à l'intérieur de la Communauté, pour autant qu'elle n'est pas admise par des dispositions spécifiques du traité."

84 "Common market: a more developed type of customs union in which, in addition to the free movement of goods between member states, labour, capital and services can also move without restriction. Common markets lead to highly integrated economies." (GOODE, Walter. Dictionary of trade policy terms. 4th ed. Cambridge, UK: New York, NY: Cambridge University Press, 2003).

85 "Four freedoms: the free movement of goods, capital, labour and services. The expression is often used in the context of the Treaty of Rome where they are mandated in Titles I and III." (GOODE, Walter. Dictionary of trade policy terms. 4th ed. Cambridge, UK: New York, NY: Cambridge University Press, 2003). 
Posição seguida pela doutrina europeia ${ }^{86}$, com reflexos em todo o mundo, inclui o homem em todas as suas dimensões, visão que ultrapassa a interpretação econômica de fatores de produção, conceito aprimorado pela escola clássica dos economistas dos séculos XVIII e XIX, a partir das formulações de Adam Smith.

O primeiro tratado internacional a prever um mercado comum nessa perspectiva foi o Tratado de Roma ${ }^{87}$. Apesar de não definir o termo, permitiu que se chegasse a um conceito, baseado nos pilares que deveriam ser edificados para a sua concretização: ${ }^{88}$

a) O primeiro pilar corresponde ao adensamento do conceito de livre trânsito de mercadorias, assim entendido como a eliminação ampla de entraves aduaneiros, não aduaneiros e de qualquer efeito restritivo equivalente entre os países membros.

Impõe-se, a partir dessa interpretação, a eliminação não só dos tributos cobrados nas aduanas, mas as limitações não aduaneiras e qualquer medida de efeito equivalente.

Nesse sentido, a eliminação dos entraves comerciais deve abranger as barreiras técnicas, quantitativas, fiscais, comerciais, restrições monetárias e ajudas outorgadas pelos Estados que afetem a livre comercialização de mercadorias.

Na União Europeia, por exemplo, esse entendimento foi confirmado em diversas decisões tomadas pelo Tribunal de Justiça, e a farta jurisprudência pode ser condensada no sentido de afirmar que o mercado comum, embora congregue países distintos, deve funcionar como um mercado interno de um território unificado. ${ }^{89}$

Outros princípios de índole jurisprudencial foram importantes para a construção do mercado comum europeu, como, por exemplo, o princípio do reconhecimento mútuo. Para que seja assegurada a livre circulação sem que haja uma completa unificação de todos os regulamentos técnicos relativos aos produtos que circulam no mercado comum, a venda de um produto legalmente fabricado em um Estado membro não pode ser proibida em outro, ainda que haja restrições técnicas ou qualitativas para o similar produzido no seu território. Além de confirmar a compreensão de livre circulação, é fortalecido o princípio da

\footnotetext{
${ }^{86}$ Por todos: MATTERA, Alfonso. El mercado único europeo: sus reglas, su funcionamento. Traducción al castellano por Cora Zapico Landrove. Madrid: Cívitas, 1991.

${ }^{87}$ A Comunidade Europeia do Carvão e do Aço (CECA) propôs a criação de um mercado comum entre os seus fundadores, entretanto limitado à circulação do carvão e do aço.

${ }^{88}$ MATTERA, Alfonso. El mercado único europeo: sus reglas, su funcionamento. Traducción al castellano por Cora Zapico Landrove. Madrid: Cívitas, 1991. p. 55-57.

${ }^{89}$ Conforme estabelece a sentença Schul, de 5 de maio de 1982: Considerando 33: “[...] La noción de mercado comum, delimitada por una reiterada jurisprudencia, comprende la eliminación de todas las trabas a los intercambios intracomunitarios com vistas a la fusión de los mercados nacionales en un mercado único que funcione en condiciones lo más similares posible a las de un verdadero mercado interior [...]." (MATTERA, Alfonso. El mercado único europeo: sus reglas, su funcionamento. Traducción al castellano por Cora Zapico Landrove. Madrid: Cívitas, 1991. p. 42).
} 
subsidiariedade, evitando-se a criação de uma regulamentação pormenorizada em nível comunitário.

b) O segundo pilar confirma a obrigatoriedade de ação de uma tarifa aduaneira comum, que deverá ser praticada por todos os países membros em relação a terceiros Estados. Pressupõe, dessa forma, a adoção de uma política comercial comum em relação aos países não membros.

As disposições expressas nas alíneas supra "a" e "b" reafirmam a noção de união aduaneira perfeita, como condição para o estabelecimento do mercado comum.

c) O terceiro pilar estabelece as primeiras novidades em relação aos clássicos tratados internacionais de comércio, ao estabelecer a eliminação de todos os obstáculos à livre circulação de pessoas e serviços.

A liberdade de movimentação de pessoas alcança dimensões complexas que ultrapassam o direito de ir e vir, sem que haja controles de fronteira e de imigração, e vão além das questões econômicas e sociais. Liberdade plena, como disse Rui Barbosa, deve, inclusive, ir além do simples direito de locomoção:

Para assegurar a liberdade pessoal, não basta proteger a de locomoção. O indivíduo não é livre, porque pode mudar de situação na superfície da terra, como o animal e como os corpos inanimados. Há liberdades, que interessam a personalidade ainda mais diretamente, e que são a égide dela. ${ }^{90}$

O livre trânsito de pessoas exige a harmonização de diversos domínios relacionados aos direitos de moradia, de aposentadoria, de formação educacional, à saúde, de exercício profissional e todos os demais direitos e garantias fundamentais consagrados na Declaração Universal dos Direitos Humanos. ${ }^{91}$

Não há como negar que esta liberdade vincula-se à necessidade de conceber uma cidadania em complemento à nacional, como asseveram de forma unânime os autores nacionais e europeus. ${ }^{92}$

90 BARBOSA, Rui. O habeas corpus e a imprensa. Obras completas de Rui Barbosa. Rio de Janeiro: Imprensa Oficial, 1893. v. 20, t. 4, p. 141.

${ }^{91}$ Adotada e proclamada pela Assembleia Geral na sua Resolução 217A (III) de 10 de dezembro de 1948.

${ }^{92}$ No Brasil: BARACHO, José Alfredo de Oliveira. Teoria geral da cidadania: a plenitude da cidadania e as garantias constitucionais e processuais. São Paulo: Saraiva, 1995; WOLKMER, Antonio Carlos. Integração interamericana, comunitarismo jurídico e cidadania supranacional. Revista de Informação Legislativa, Brasília, v. 35, n. 140, p. 259-265, out./dez. 1988; STELGES, Isabela Kathrin. A cidadania da União Europeia: uma sugestão para o Mercosul. Belo Horizonte: Del Rey, 2002. Na Europa: AZEVEDO, Maria Eduarda. A Europa em movimento: apostas e desafios no limiar do novo século. Lisboa: Calouste Gulberkian, 1997; CHUECA SANCHO, Ángel G. Los derechos fundamentales en la Comunidad Europea. Barcelona: Bosch, 1989; FONTAINE, Pascoal. La Europa de los ciudadanos. Luxemburgo: Oficina de Publicaciones Oficiales de las Comunidades Europeas, 1994; HABERMAS, Jürgen. O Estado-nação 
Na União Europeia, a livre circulação de pessoas no território da comunidade ${ }^{93}$ é reconhecida como um direito fundamental que teve efetivamente início após a assinatura do Acordo de Schengen, em 1985, fato que propiciou a abolição de controles de fronteira para os cidadãos do espaço europeu. A livre circulação de pessoas significa que os cidadãos podem circular livremente entre os Estados membros para morar, trabalhar, estudar ou se aposentar em outro país. Isso exigiu a redução de formalidades administrativas e o reconhecimento das qualificações profissionais de outros Estados. ${ }^{94}$

A partir desse prisma, inúmeras harmonizações foram realizadas, no sentido de garantir a liberdade, dentre as quais citamos o direito de residência ${ }^{95}$, mobilidade dos trabalhadores e igualdade de tratamento ${ }^{96}$, a coordenação dos serviços sociais ${ }^{97}$, liberdade de estabelecimento e livre prestação de serviços. ${ }^{98}$

d) O quarto pilar prevê o livre movimento de capitais, que deságua na livre conversibilidade das respectivas moedas nacionais no conjunto de todas as operações financeiras realizadas por uma pessoa física ou jurídica entre os países membros. Tal prerrogativa engloba, para citar apenas estes, os depósitos bancários, os empréstimos, a poupança, as inversões imobiliárias, o movimento de investimentos, tais como compras de bens e ações entre os países.

A livre circulação de capitais é a única medida que é concedida igualmente a não membros, em razão da globalização da economia e da crescente aproximação dos mercados financeiros, entretanto, para frear os riscos inerentes a essas movimentações de capital, a diretiva europeia que regula esta liberdade estabelece uma importante cláusula de salvaguarda. $^{99}$

e) O quinto pilar descreve a importância do estabelecimento de um regime que garanta que a concorrência não será falseada nesse ambiente, consagrando o princípio da

europeu frente aos desafios da globalização: o passado e o futuro da soberania e da cidadania. Novos Estudos Cebrap, São Paulo, n. 43, p. 87-101, nov. 1995.

${ }^{93}$ Exigiu um endurecimento em relação à entrada e residência de cidadãos de países terceiros, por meio de uma política comum de imigração e concessão de asilo.

${ }^{94}$ Hoje, na União Europeia, a maioria das qualificações profissionais e dos diplomas obtidos em um país membro é reconhecida nos demais.

95 Directiva 2004/38/CE do Parlamento Europeu e do Conselho, de 29 de abril de 2004, relativa ao direito à livre circulação e residência dos cidadãos da União e dos membros das suas famílias no território dos Estados membros.

${ }^{96}$ Regulamento (UE) n. 492/2011 do Parlamento Europeu e do Conselho, de 5 de abril de 2011, relativo à livre circulação dos trabalhadores na União.

${ }^{97}$ Regulamento (CE) n. 883/2004 do Parlamento Europeu e do Conselho, de 29 de abril de 2004, relativo à coordenação dos sistemas de segurança social.

${ }^{98}$ Directiva 2006/123/CE do Parlamento Europeu e do Conselho, de 12 de dezembro de 2006, relativa aos serviços no mercado interno [Jornal Oficial L 376 de 27.12.2006].

${ }^{99}$ Directiva 88/361/CEE del Consejo, de 24 de junio de 1988, para la aplicación del artículo 67 del Tratado. 
liberdade de concorrência ${ }^{100}$. Há a preocupação de desenvolver uma política comum para setores como a agricultura, transportes e outros que sejam tipicamente sensíveis para a região, do ponto de vista econômico, social ou cultural.

Para criar um verdadeiro mercado comum, as restrições à liberdade de circulação e as práticas anticoncorrenciais devem ser, tanto quanto possível, eliminadas ou reduzidas, simultaneamente com a criação de um ambiente que incentive a inovação e o investimento.

f) Em sequência, o sexto pilar identifica a necessária coordenação das políticas econômicas dos Estados membros e o controle de eventuais desequilíbrios de suas balanças de pagamento, de modo a preservar a equidade e promover crescimento positivo para todos os membros.

g) O sétimo pilar consagra a necessária aproximação das legislações nacionais, na medida necessária para o funcionamento do mercado comum.

Note-se que para haver livre circulação em um mercado verdadeiramente integrado, as fronteiras desaparecem e, para que isso ocorra, é necessário que os países promovam uma reformulação jurídica, na construção de uma legislação harmônica que impeça uma fuga de pessoas, dos serviços, de empresa e de capitais em direção aos países que oferecem maiores vantagens que os demais Estados. Exige políticas comuns e normas harmonizadas nos diversos setores da vida econômica, para garantir a liberação do intercâmbio. ${ }^{101}$

A construção de um mercado comum traz em seu étimo a necessidade de harmonização das legislações tributárias e, considerando que os tributos diretos são facilmente harmonizáveis, a experiência europeia de unificação demonstrou que a harmonização dos tributos indiretos é a mais laboriosa.

Por fim, a maior complexidade deste modelo de integração entre países suscita a constituição de órgãos de caráter supranacional, encarregados de orientar o processo.

\section{(iv) União Econômica e Política}

A partir do mercado comum pode-se alcançar a união econômica, o que pressupõe a adoção de uma moeda comum e uma completa harmonização das políticas econômicas, podendo alcançar, em maior ou menor grau, a união política. De acordo com Béla Balassa,

\footnotetext{
${ }^{100}$ Não consideramos que a livre concorrência enquadre-se, como uma quinta liberdade, mas um princípio a nortear todo o sistema comunitário. O princípio da livre concorrência é mero desdobramento do princípio da liberdade econômica Afinal, como afirma Casella, os Tratados de Paris e Roma, ao constituírem as Comunidades, formularam princípios basilares do ordenamento que se inaugurava: o princípio democrático, o princípio da liberdade econômica e o princípio da primazia do direito comunitário. (CASELLA, Paulo Borba. Comunidade Econômica Europeia e seu ordenamento jurídico. São Paulo: LTr, 1994. p. 203).

${ }^{101}$ DINH, Nguyen Quoc; DAILLIER, Patrick; PELLET, Alain. Droit international public. 4e éd. Paris: Librairie Générale de Droit et de Jurisprudence (LGDJ), 1992. p. 42.
} 
“pressupõe a unificação das políticas monetárias, fiscais, sociais e anticíclicas, e exige o estabelecimento de uma autoridade supranacional". ${ }^{102}$

\subsection{Harmonização das legislações tributárias: a pedra angular da constituição do mercado comum}

O desígnio de constituição de um mercado comum implica a formação de um direito positivo novo, um trabalho de constituição e "também de sutura das velhas e das novas normas jurídicas." ${ }^{103}$

Pode-se dizer que o direito comunitário e o direito da integração se dão, em grande medida, pela aproximação das legislações dos Estados ${ }^{104}$ e o grande desafio enfrentado por ambos são, em essência, a forma de entronizar ou reconhecer o novo direito face ao ordenamento jurídico nacional e a garantia de uma interpretação uniforme, via de regra assegurada pela existência de um tribunal permanente e supranacional.

No curso da integração entre países, avultou a necessidade de conhecimento e de comparação dos direitos vigentes nos Estados-membros, em prol da segurança jurídica. Afinal, como assegurar tantas liberdades se o direito interno de cada país for dissonante ou impeditivo?

Emerge, portanto, a necessidade de aproximação ou de harmonização das legislações dos países que pretendem se integrar e a experiência mais avançada, vivenciada pela então Comunidade Econômica Europeia (CEE), demonstrou que o fio condutor desse processo é o complexo equilíbrio de forças entre a parcela de soberania conferida às novas instituições e a potestade remanescente no seio dos Estados, moldada pelos princípios da atribuição de competências, da subsidiariedade e da proporcionalidade. ${ }^{105}$

102 BALASSA, Béla. Teoria da integração económica. Tradução de Maria Filipa Gonçalves e Maria Elsa Ferreira. 3. ed. Lisboa: Clássica Editora, 1982. p. 128).

103 CONSTANTINESCO, Leontin-Jean. Tratado de direito comparado: introdução ao direito comparado. Ed. brasileira organizada por Maria Cristina de Cicco. Rio de Janeiro: Renovar, 1998. p. 57.

104 Sugere-se a leitura dos seguintes autores: PIPKORN, Jörn. Les méthodes de rapprochement des législations à l'intérieur de la CEE. In: L'INFLUENCE des Communautés Européennes sur le droit international privé des États membres, Luxembourg:Institut Universitaire International, 1981. p. 13-48; RUIZ, Nuno. O princípio da subsidiariedade e a harmonização de legislações na Comunidade Europeia. In: CUNHA, Paulo de Pitta e et al. A União Europeia na encruzilhada. Coimbra: Almedina, 1996. p. 129-138; CALHEIROS, José Maria de Albuquerque. Harmonização de legislações - que futuro? In: PEREIRA, André Gonçalves et al. Em torno da revisão do Tratado da União Europeia. Coimbra: Almedina, 1997. p. 134-144; PAPARELLA, Franco. L'armonizzazione del sistema tributario nazionale: rispetto al diritto tributario europeo: l'esperienza italiana. Revista Internacional de Direito Tributário, Belo Horizonte, Associação Brasileira de Direito Tributário (ABRADT); Del Rey, v. 5, p. 3-31, jan./jun. 2006.

105 Princípios de índole jurisprudencial, mas hoje previstos no artigo $5^{\circ}$ do Tratado da União Europeia. Estabelecem, nesta ordem: a União deve atuar apenas nos limites das competências que lhe foram 
Essa harmonização deverá ser promovida na medida necessária para a consecução dos fins da integração, de modo a assegurar a constituição do mercado comum e, ao mesmo tempo, conviver com as particularidades e especificidades normativas de cada integrante, sem descuidar que a integração ocasiona relevantes transformações nos Estados membros, em prol de objetivos compartilhados ${ }^{106}$, mas não coaduna com a ideia de supressão ou aniquilamento do Poder Legislativo dos países integrados.

O Tratado de Roma $^{107}$ e o Tratado de Assunção ${ }^{108}$, que almejaram construir um mercado comum, apoiam-se no compromisso dos Estados membros de aproximarem as suas legislações e promoverem a sua harmonização, na medida necessária à criação do mercado comum. Mas, afinal, como devemos compreender o signo harmonização, de forma a afastar a possível vagueza ou ambiguidade do termo?

Para responder adequadamente a essa pergunta, é necessário considerar que no período em que foi firmado o Tratado de Roma, as ideias de unificação do direito ${ }^{109}$, gestadas no século XIX, estavam desacreditadas, em grande parte pelos impactos negativos das duas guerras mundiais. ${ }^{110}$

Esse embate, relacionado às discussões de autonomia do direito comparado e à definição do seu objeto, é que vai influenciar a eleição da nomenclatura utilizada no

atribuídas pelos Estados membros em determinados domínios; quando não se tratar de seu domínio exclusivo, somente deve atuar quando a sua ação for mais eficaz do que uma ação desenvolvida em nível nacional, regional ou local; e as suas ações não devem exceder o necessário para atingir os objetivos dos tratados. Destacam-se as reflexões de Fausto de Quadros sobre o tema. (QUADROS, Fausto de. Prefácio. In: VILHENA, Maria do Rosário. O princípio da subsidiariedade no direito comunitário. Lisboa: Almedina, 2002).

${ }^{106}$ Nesse sentido, corretas as reflexões de: GOMES, Joséli Fiorin. Dificuldades à ampliação da integração regional: um estudo a partir da complexa uniformização jurídica em matéria de direito do consumidor na União Europeia e no Mercosul. Revista de la Secretaría del Tribunal Permanente de Revisión, Asunción, Paraguay, año 1, n. 2, p. 151-169, ago. 2013; DAVID, René. Traité élémentaire de droit civil comparé. Paris: Librairie Générale de Droit du Jurisprudence, 1950. p. III.

107 Tratado che istituisce la Comunità Economica Europea: "Articolo 3: Ai lini enunciati all'articolo precedente, l'azione della Comunità importa, alle condizioni e secondo il ritmo previsto dal presente Trattato: [...] h) il ravvicinamento delle legislazioni nazionali nella misura necessaria al funzionamento del mercato comune."

108 Tratado de Assunção: “Artigo I: Os Estados Partes decidem constituir um Mercado Comum, que deverá estar estabelecido a 31 de dezembro de 1994, e que se denominará 'Mercado Comum do Sul' (MERCOSUL). Este Mercado Comum implica: [...] O compromisso dos Estados Partes de harmonizar suas legislações, nas áreas pertinentes, para lograr o fortalecimento do processo de integração."

${ }^{109}$ A construção do mercado comum europeu conviveu com os intensos debates sobre a autonomia do direito comparado, como ciência, ou um método especial a ser utilizado na pesquisa jurídica, bem como se o seu objeto restringia-se à busca pela unificação do direito. Para acompanhar a evolução deste assunto, sugere-se a leitura dos seguintes autores: MONACO, Riccardo. Comparaison et rapprochement des législations dans le marché commun européen. Revue Internationale de Droit Comparé, v. 12, n. 1, p. 64-65, janv./mars 1960; DAVID, René. Traité élémentaire de droit civil comparé. Paris: Librairie Générale de Droit du Jurisprudence, 1950; SACCO, Rodolfo. Introdução ao direito comparado. Tradução de Véra Jacob de Fradera. São Paulo: Revista dos Tribunais, 2001.

110 SACCO, Rodolfo. Introdução ao direito comparado. Tradução de Véra Jacob de Fradera. São Paulo: Revista dos Tribunais, 2001. p. 33. 
Tratado da CEE, posteriormente difundida nos demais tratados de constituição de um mercado comum, inclusive no MERCOSUL.

Rodolfo Sacco ${ }^{111}$, ao narrar as discussões sobre a autonomia do direito comparado e classificar as correntes de pensamento ao longo da história, relata que os primeiros comparatistas pretendiam contrastar os direitos estrangeiros, com a finalidade de colocar em evidência as regras comuns pertencentes aos diversos ordenamentos jurídicos. A comparação tinha como objetivo realçar os princípios universais presentes em cada ordenamento. $^{112}$

Após a Primeira Guerra Mundial, conscientes da necessidade de maior aproximação entre os países, para se evitarem novas catástrofes, propuseram-se a não mais encontrar as concordâncias, mas a criá-las por meio dos ideais de unificação ${ }^{113}$ e uniformização $^{114}$ do direito. Defendiam que entre a comparação e a unificação havia um vínculo biunívoco e indissolúvel. Por óbvio, a reação daqueles que se opunham à unificação do direito, pelas mais diversas razões, fez aumentar as críticas a respeito do reconhecimento do direito comparado como ramo autônomo do direito. ${ }^{115}$

Coube a René David a percepção de que o ideal universalista deveria ser repensado, porque "los tiempos no están aún maduros para llevar a cabo una unificación internacional de Derecho, y a lo más a que puede aspirarse es a lograr algunos resultados concretos entre paises ligados por una tradición jurídica comúm". 116

111 SACCO, Rodolfo. Introdução ao direito comparado. Tradução de Véra Jacob de Fradera. São Paulo: Revista dos Tribunais, 2001. p. 29.

${ }^{112}$ Os autores consultados que abordaram o assunto e que contribuíram para as conclusões apresentadas foram: LAMBERT, Édouard. La fonction du droit civil comparé: introduction Paris: V. Giard \& E. Briere, 1903; AMARI, Emerico. Critica e storia di uma scienza delle legislazioni comparate. Roma: Rubbettino, 2005. ANCEL, Marc. Utilità e metodi del diritto comparato: elementi d'introduzione generale allo studio comparato dei diritti. Camerino: Universita di Camerino, 1974; MONACO, Riccardo. Comparaison et rapprochement des législations dans le marché commun européen. Revue Internationale de Droit Comparé, v. 12, n. 1, p. 64-65, janv./mars 1960; DAVID, René. Traité élémentaire de droit civil comparé. Paris: Librairie Générale de Droit du Jurisprudence, 1950.

113 A uniformização de normas ocorre quando diferentes legisladores adotam uma norma formulada do mesmo modo, ou um único legislador introduz em vários ordenamentos normas formuladas de modo idêntico.

${ }^{114} \mathrm{Na}$ unificação, há a criação de uma norma única destinada a substituir uma pluralidade de normas divergentes e autônomas, então vigentes no ordenamento interno de cada país.

115 "Os adversários da unificação, que eram muitos, se converteram em inimigos do direito comparado, esquecendo-se de todos os serviços que pode render o método comparativo. É preciso colocar um fim a esta confusão e dar se perfeitamente conta de que a unificação do direito é só um dos múltiplos fins a que podem servir os estudos dos direito estrangeiros e a comparação dos direitos." (DAVID, René. Traité élémentaire de droit civil comparé. Paris: Librairie Générale de Droit du Jurisprudence, 1950. p. 138 nossa tradução).

${ }^{116}$ DAVID, René. Los grandes sistemas juridicos contemporáneos: derecho comparado. Traducción de la 2. edición francesa por Pedro Bravo Gala. Madrid: Aguilar, 1969. p. 68. Após a Segunda Guerra Mundial, não havia desaparecido a preocupação originária pela unificação do direito. O que ocorreu é que ela já não constituía mais a preocupação exclusiva dos comparatistas e tão pouco se preservava um espírito tão 
Ao reformular o objeto do direito comparado, defendeu que a comparação entre direitos estrangeiros poderia assegurar uma consciência mais clara e definida do próprio direito interno, com o propósito de melhorá-lo. ${ }^{117}$

Dessa forma, consagrou a comparação de direitos como meio de promover a harmonização dos diversos direitos que se comparam, já que a unificação não é uma solução desejável em certos casos, nem possível, sendo preferível lograr uma certa harmonização deles. ${ }^{118}$

Riccardo Monaco ${ }^{119}$ identificou corretamente que a construção do mercado comum ensejou um novo desafio à ciência jurídica e constatou que a ideia de um direito uniforme comunitário seria de difícil concretização. Sendo assim, a harmonização surge como uma nova proposta para a solução do problema:

\begin{abstract}
C'est pour cette raison que les rédacteurs du traité de Marché commun se sont inspires d'une idée qui a commence à poindre en plusieurs occasions, à l'époque actuelle, chaque fois qu'on a dû établir un système postulant l'élimination des divergences les plus marquées de réglementation existant entre des legislations nationals différentes. Cette idée consiste à rapprocher et à comparer des norms d'origine et de caractere différents en vue de leur harmonisation.
\end{abstract}

Assim, forjou-se que para além da unificação do direito, um dos objetos do direito comparado é o estudo da harmonização jurídica ${ }^{120}$, posto que a complexidade dos ordenamentos jurídicos desaconselha "as equações simples e ingênuas entre comparação e descoberta de unidade entre os direitos, ou ainda entre comparação e construção da unidade." ${ }^{121}$

idealista como antes. É importante destacar que nas edições revisadas e publicadas a partir dos anos 80, a expressão reproduzida acima, desapareceu da sua obra.

117 Assevera: "Hemos visto en la sección precedente a contribuição que el estudio de los Derechos extranjeros puede aportar al mejor conocimiento de un Derecho nacional cualquiera. Con el método comparativo podemos comprender mejor ese Derecho; descubrir su soluciones; analizar su estructura; clasificar sus conceptos y extraer sus tendencias. En el capítulo siguiente veremos como puede ayudarnos ese mismo método para mejorar nuestro Derecho nacional." (DAVID, René. Tratado de derecho civil comparado: introducción al estudio de los derechos extranjeros y al método comparativo. Traducción de Javier Osset. Madrid: Revista de Derecho Privado, 1953. p. 100).

${ }^{118}$ DAVID, René. Tratado de derecho civil comparado: introducción al estudio de los derechos extranjeros y al método comparativo. Traducción de Javier Osset. Madrid: Revista de Derecho Privado, 1953. p. 137.

${ }^{119}$ MONACO, Riccardo. Le rapprochement des législations nationales dans le cadre du marché commun. Annuaire Français de Droit International, v. 3, p. 559, 1957.

${ }^{120}$ Mas não se limita a isso. Segundo o autor, os interesses do direito comparado podem ser classificados em três grupos: a) é útil nas investigações históricas ou filosóficas relativas ao direito; b) para conhecer melhor e aperfeiçoar o direito nacional; c) compreender os povos estrangeiros e possibilitar um regime mais adequado para as relações internacionais, sendo indispensável para qualquer intento de harmonização ou unificação do direito.

${ }^{121}$ SACCO, Rodolfo. Introdução ao direito comparado. Tradução de Véra Jacob de Fradera. São Paulo: Revista dos Tribunais, 2001. p. 29. 
A harmonização das legislações não pode ser realizada sem o estudo prévio e profundo dos direitos que se pretende harmonizar, que corresponde à ideia de: (i) apurar as diferenças que podem existir entre as normas vigentes nos Estados membros; (ii) averiguar se são passíveis de eliminação e quais os meios para promovê-las; (iii) compreender as diferenças e as suas razões de ser, antes de harmonizá-las. Essa concepção terá forte influência nos capítulos seguintes deste estudo. ${ }^{122}$

Acertadamente, não invocar o estudo comparativo apenas como fase introdutória para uma futura unificação do direito respondeu aos anseios dos países fundantes do direito comunitário: aproximar as legislações apenas naquilo que fosse necessário para atingir os fins pretendidos no processo de integração, o que pressupõe observar o grau e a flexibilidade inerentes a cada desafio normativo proposto.

Por essa razão, o vocábulo harmonização declina a uma conceituação que pretenda defini-lo como gênero formado por espécies pouco flexíveis, delimitadas e incapazes de abarcar a totalidade, extremadas ora a descrever o seu processo de execução, ora os meios eleitos para a sua implementação, ou ainda os resultados alcançados pelo processo de aproximação legislativa.

Isso significa dizer que não serão adotados, propositadamente, os esforços de parte da doutrina que propõe conceituar a harmonização sob os signos da coordenação, da uniformização ou da unificação do direito interno dos países membros ${ }^{123}$, ou a reduzi-la a uma simples busca pela definição da lei aplicável no caso de conflito de leis. ${ }^{124}$

Reafirmamos que a harmonização das legislações se opõe à busca por um conceito classificatório rígido e preciso, sem qualquer prejuízo ou risco à clareza do termo. ${ }^{125}$

\footnotetext{
${ }^{122}$ DAVID, René. Tratado de derecho civil comparado: introducción al estudio de los derechos extranjeros y al método comparativo. Traducción de Javier Osset. Madrid: Revista de Derecho Privado, 1953. p. 139.

${ }^{123}$ Podemos citar: LIMPENS, Anne. Harmonisation des législations dans le cadre du marché common. Revue International de Droit Comparé, v. 19, n. 3, p. 621-653, juil./sept. 1967; CATALANO, Nicola. Manuel de droit des Communautés Européennes. Paris: Dalloz et Sirey, 1962; SCHOUERI, Luís Eduardo. Harmonização tributária no Mercosul. Revista Direito Mackenzie, São Paulo, ano 1, n. 2, p. 169-178, 2000; FERNANDES, Edison Carlos. Normas tributárias no Mercosul. In: MARTINS, Ives Gandra da Silva (Coord.). O direito tributário no Mercosul. Rio de Janeiro: Forense, 2000. p. 177-220.

124 Por todos: COUTO, Jeanlise Velloso. A tributação no Mercosul. In: CASELLA, Paulo Borba; LIQUIDATO, Vera Lúcia Viegas (Coords.). Direito da integração. São Paulo: Quartier Latin, 2006. p. 265-266.

${ }^{125}$ Paulo Borba Casella, após apresentar os conceitos sobre a harmonização das legislações, conclui que mais importante que as definições são os caminhos para alcançar os melhores resultados, produzindo as menores quantidades de alterações nos sistemas jurídicos nacionais (CASELLA, Paulo Borba. Modalidades de harmonização, unificação e uniformização do direito: o Brasil e as convenções interamericanas de direito internacional privado. In: CASELLA, Paulo Borba; ARAUJO, Nadia de (Coords.). Integração jurídica interamericana: as Convenções Interamericanas de Direito Internacional Privado (CIDIPs) e o direito brasileiro. São Paulo: LTr, 1988. p. 78-79).
} 
Ao contrário, considerada a multiplicidade de temas que necessitam ser harmonizados e os fatores que afetam a sua aplicação, impõe reconhecer que estamos diante de um signo que, em oposição ao conceito, exige a abertura, a gradação, o sentido, a inteireza e a aproximação da realidade, conforme ensina Misabel de Abreu Machado Derzi, seguindo as lições de Leenen. ${ }^{126}$

Assentadas essas balizas, reconhecemos as seguintes variáveis para a concretização do processo de harmonização das legislações dos países que pretendem se integrar: (i) a identificação do modelo de integração que se pretende alcançar; (ii) a eleição do tema a ser harmonizado; (iii) o dimensionamento do grau de aproximação legislativa necessário para alcançar os objetivos acordados; (iv) a definição dos meios que serão utilizados para a sua implementação, abrangendo o seu desenvolvimento, a forma de introdução das modificações no ordenamento jurídico interno dos Estados membros, bem como o mecanismo a ser utilizado para a solução de controvérsias.

Definidas essas premissas, podemos afirmar que a construção de um mercado comum requer a aproximação das legislações e a harmonização tributária, que ocupa um lugar relevante, à medida que está umbilicalmente relacionada ao reconhecimento das quatro grandes liberdades: a circulação de pessoas, bens, serviços e capitais. ${ }^{127}$

\footnotetext{
126 “O tipo é pois, uma unidade dotada de sentido, ao mesmo tempo, uma abstração mais concreta do que o conceito abstrato classificatório, estruturada de forma flexível, aberta e graduável. [...] A gradação decorre dos diferentes graus de intensidade, frequência e combinações em que se dão as características de um tipo. Essa gradualidade leva à possibilidade de ordenação em série comparativa, com base no relacional mais ou menos. Enquanto no conceito classificatório tem cabida a identificação do gênero e a separação rigorosa entre as espécies, na tipológica isso não será possível, mas apenas se dá uma escala comparativa que vai do mais ao menos típico, até o limite do atípico.[...] O tipo, por isso, permite maior aproximação com a realidade jurídica, por se tratar de uma abstração rica de conteúdo, uma descrição plena de dados referenciais do objeto. [...] A aproximação do tipo com a realidade e sua riqueza de características descritivas colocam-no entre o individual e a abstração conceitual. Ao mesmo tempo sua integridade de sentido e totalidade situam-no em posição intermediária, vale dizer, como abstração seletiva e valorativa."(DERZI, Misabel de Abreu Machado. Tipo ou conceito no direito tributário. Revista da Faculdade de Direito da Universidade Federal de Minas Gerais, Belo Horizonte, v. 31, n. 30/31, p. 213260, 1987/1988).

127 "La necessità di realizzare un mercato único delle merci, delle persone, dei servizi e dei capitali, $i$ cui movimenti in ambito comunitario devono essere regolamentati alla stregua dei movimenti circoscritti all'interno dei singoli Stati, richiede infatti um livellamento delle legislazioni nazionali in tutti $i$ settori normativi, ivi compreso quello fiscale, nel quale esso può alternativamente tradursi nella semplice modifica di alcune norme nell ambito di determinati tributi, nell'adequamento dei tributi esistendi ad um modello único, oppure, infine, nella soprressione sic et simlliciter di tributi incompatibili com tale obiettivo." (GALLO, Franco; MELIS, Giuseppe. L'elusione fiscale internazionale nei processi di integrazione tra stati: l'esperienza delle Comunità Europea. In: CONGRESSO INTERNACIONAL DE DIREITO TRIBUTÁRIO,1., 1998, Vitória. Justiça tributária: direitos do fisco e garantias dos contribuintes nos atos da administração e no processo tributário. São Paulo: Max Limonad, 1998. p. 165).
} 
Nessa esteira, ciente que a adoção do princípio da não discriminação ${ }^{128}$ e as

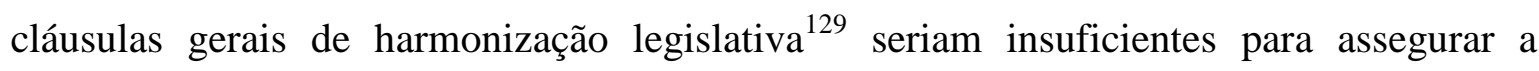
construção do mercado comum, o Tratado de Roma estabeleceu que os Estados membros deveriam se comprometer a harmonizar a tributação indireta ${ }^{130}$, já que os países fundantes praticavam modelos muito distintos de tributação sobre o consumo ${ }^{131}$, que poderiam afetar a concorrência e as devoluções de tributos aos exportadores, comprometendo a dinâmica do mercado comum. ${ }^{132}$

A harmonização dos impostos indiretos sobre o consumo também foi objeto de destaque no tratado de constituição da CEE, porque nesse tipo de tributo, o ônus econômico é transferido para o consumidor final por meio do mecanismo dos preços ${ }^{133}$, e os modelos vigentes na Europa dos seis ${ }^{134}$ poderiam causar distorções à livre concorrência, prejudicando a livre circulação de mercadorias e de serviços nos países integrados.

No MERCOSUL, o Tratado de Assunção estabelece o princípio da não discriminação no artigo $7^{\circ}$ e o compromisso geral de harmonização das legislações no artigo $1^{\circ}$, sem, contudo, atentar para as significativas divergências existentes na tributação

\footnotetext{
128 “ARTICOLO 95. Nessuno Stato membro applica direttamente o indirettamente ai prodotti degli altri Stati membri imposizioni interne, di qualsivoglia natura, superiori a quelle applicate direttamente o indirettamente ai prodotti nazionali similari. Inoltre, nessuno Stato membro applica ai prodotti degli altri Stati membri imposizioni interne intese a proteggere indirettamente altre produzioni. Gli Stati membri aboliscono o modificano, non oltre l'inizio della seconda tappa, le disposizioni esistenti al momento dell'entrata in vigore del presente Trattato che siano contrarie alle norme che precedono."

${ }^{129}$ Artigos 100, 101 e 102 do Tratado de Roma.

130 "ARTICOLO 99. La Commissione esamina in qual modo sia possibile armonizzare, nell'interesse del mercato comune, le legislazioni dei singoli Stati membri relative alle imposte sulla cifra d'affari, alle imposte di consumo e ad altre imposte indirette, ivi comprese le misure di compensazione applicabili agli scambi fra gli Stati membri.La Commissione sottopone proposte al Consiglio che deliberà all'unanimità, fatte salve le disposizioni degli articoli 100 e 101."

131 "O panorama da tributação indireta na Europa dos anos cinquenta era de tal maneira variado que tornava irrealizável qualquer projeto de integração. O Comitê Fiscal e Financeiro da CEE, no relatório Neumark, apontou para a necessidade de harmonização da imposição indireta a partir da adoção, por todos os Estados-membros, de um imposto sobre o valor agregado concebido nos moldes da taxe sur la valeur ajoutée, vigente na França desde 1954. Nesta modalidade de imposto apenas se tributa a riqueza agregada em cada etapa da cadeia de circulação da mercadoria, deduzindo-se do montante devido por sua venda a quantia paga pelo comerciante anterior. Desta forma, eliminam-se as distorções econômicas causadas pela tributação cumulativa, em cascata." (SANTIAGO, Igor Mauler. A harmonização das legislações tributárias no Mercosul. Revista do CAAP, Belo Horizonte, Centro Acadêmico Afonso Pena, UFMG, v. 2, n. 2, p. 133-152).

132 "ARTICOLO 96. I prodotti esportati nel territorio di uno degli Stati membri non possono beneficiare di alcun ristorno d'imposizioni interne che sia superiore alle imposizioni ad essi applicate direttamente o indirettamente. ARTICOLO 97. Gli Stati membri che riscuotono l'imposta sulla cifra di affari in base al sistema dell'imposta cumulativa a cascata possono, per quanto riguarda le imposizioni interne che applicano ai prodotti importati o i ristorni che accordano ai prodotti esportati, procedere alla fissazione di aliquote medie per prodotto o gruppo di prodotti, senza pregiudizio tuttavia dei principi enunciati negli articoli 95 e 96. Qualora le aliquote medie fissate da uno Stato membro non siano conformi ai principi suindicati, la Commissione rivolge a tale Stato le direttive o decisioni del caso."

${ }^{133}$ SANTIAGO, Igor Mauler. A harmonização das legislações tributárias no Mercosul. Revista do CAAP, Belo Horizonte, Centro Acadêmico Afonso Pena, UFMG, v. 2, n. 2, p. 64-72, 1998.

${ }^{134}$ Países fundadores da CEE: Alemanha, Bélgica, França, Itália, Luxemburgo e Países Baixos.
} 
do consumo nos países membros que podem inviabilizar a constituição do mercado comum. Os desvios, à luz do que compreendemos por harmonização das legislações, serão objeto de análise nos Capítulos 4 e 5.

\section{$1.4 \mathrm{O}$ desafio institucional}

Um projeto de integração que pretenda estabelecer uma estreita aproximação entre países, com o objetivo de promover avanços sociais e econômicos, deve ostentar um quadro institucional condizente com a realidade que almeja constituir.

Eliminar os inúmeros obstáculos a serem transpostos para realizar o mercado comum exige ações concertadas, adoção de políticas integradas e medidas apropriadas para assegurar o cumprimento das obrigações assumidas. Essas premissas não podem ficar à mercê da vontade ou conveniência dos Estados membros, sob o risco de, a qualquer sinal de instabilidade política ou econômica, os compromissos serem adiados.

Para alcançar o sucesso pretendido, as instituições devem ser autônomas e independentes para criar o novo ordenamento jurídico comum. Cabe a elas velar e fiscalizar os comportamentos incompatíveis com os objetivos propostos, fixar metas, estabelecer prazos, investigar infrações aos princípios estabelecidos, adotar medidas necessárias para interpretar, julgar e afastar os desvios.

O primeiro desafio que se impõe para as normas expedidas pelas instituições referese à sua aplicação nos Estados membros. A necessidade ou não de validá-los conforme procedimento estabelecido no ordenamento jurídico de cada país é que irá ditar a velocidade e a possibilidade de atingir os objetivos traçados.

Em seguida, a forma de tomada de decisões, por consenso ou por outra medida de quilate, também interferirá no avanço da integração, embora seja natural que alguns domínios, como o exercício do poder de tributar, sejam reservados para decisões consensuais. Após inúmeros avanços nos temas que podem ser definidos por maioria qualificada nas instituições da União Europeia, exige-se a unanimidade para as decisões relacionas à segurança social, adesão de novos Estados, a política externa e de defesa comum, a cooperação policial entre os Estados membros e os temas tributários.

Por essas razões, a ambição de construção do mercado comum também se relaciona com a necessária alteração das Constituições ${ }^{135}$ dos Estados membros, para reconhecer a

\footnotetext{
135 Paraguai e Argentina alteraram as suas Constituições para prever a institucionalização de órgãos supranacionais comunitários de integração.
} 
existência e a possibilidade de instituições supranacionais elaborarem, na medida das competências atribuídas nos tratados firmados pelo país, normas de aplicação imediata, que independam de convalidação interna e prevaleçam sobre o interesse individual dos seus integrantes. Deve admitir ainda que um tribunal supranacional fique responsável pela aplicação uniforme do direito material comum.

Foi adotando um modelo dessa natureza ${ }^{136}$ que os países europeus tornaram realidade, etapa por etapa, superando dificuldades de toda ordem, os compromissos de uma Europa unida.

$\mathrm{O}$ avelhantado modelo intergovernamental ${ }^{137}$ de decisões atreladas à vontade $\mathrm{e}$ conveniência dos países e a exigência de internalizar as normas emanadas dos órgãos criados para promover a integração deixa a desejar frente aos desafios propostos pelos novos modelos de integração, nomeadamente um ambiente que consagre as quatro grandes liberdades. É possível progredir nesse arquétipo, mas o caminho fatalmente será longo e repleto de interrupções.

\footnotetext{
${ }^{136}$ Apesar do modelo supranacional, há autores que passaram a criticar a tomada de decisões na União Europeia após o Tratado de Lisboa: "Ao longo de todo o processo de integração europeia, temos verificado que os Estados, através do Conselho Europeu, continuam a estimular o processo de integração de acordo com os seus interesses. Apesar dos avanços evidentes no sentido de um modelo mais supranacional, os Estados conservam a sua soberania decidindo de que forma a Europa deverá ser construída. [...] há um recuo do modelo supranacional, construído gradualmente, para um modelo de cariz intergovernamental em que todo o processo volta a depender, essencialmente, da vontade estatal, sendo esta a condutora dos avanços federalizantes no futuro." (LEITE, Isabel Costa. Construção europeia: um processo supranacional ou intergovernamental? Anais do IV Congresso da Associação Portuguesa de Ciência Política, Lisboa, 7 de março de 2008).

${ }^{137}$ Já em 1948, o Congresso de Haia apontava para dois caminhos alternativos: uma Europa comunitária com um poder político independente dos Estados, de tipo supranacional, ou uma Europa baseada no poder dos Estados sob simples relações intergovernamentais. Venceu a segunda proposta.
} 


\title{
CAPÍTULO 2 - A EXPERIÊNCIA DE CONSTRUÇÃO DO MERCADO COMUM NO ÂMBITO DA UNIÃO EUROPEIA (UE)
}

\begin{abstract}
"Não podemos parar quando à nossa volta o mundo inteiro está em movimento. Consegui fazer compreender que a Comunidade que criamos não tem um fim em si mesma? É um processo de transformação que continua aquele que deu origem às nossas formas de vida nacionais ao longo de uma fase anterior na história. Como ontem as nossas províncias, hoje os nossos povos devem aprender a viver em conjunto com regras e instituições comuns livremente aceites, se quiserem atingir as dimensões necessárias ao seu progresso e manter o controle do seu destino. As nações soberanas do passado deixaram de ser o quadro onde se podem resolver os problemas do presente. E a própria Comunidade é apenas uma etapa rumo a formas de organização do mundo de amanhã."
\end{abstract}

MONNET, Jean. Memórias: a autobiografia de um dos pais fundadores da União. Lisboa: Europeia, 2006. p. 652.

\subsection{A União Europeia (UE)}

A paz perpétua tem uma longa trajetória no imaginário europeu ${ }^{138} \mathrm{e}$, naturalmente, esse desígnio foi renovado após as duas grandes guerras que devastaram política, econômica, física e moralmente o continente, na primeira metade do século XX.

As palavras de Monnet ${ }^{139}$, o inspirador da Europa unida, continuam a fomentar o paradigma da aproximação dos países como meio de preservar a paz e contribuir para o progresso social e econômico da humanidade.

São ainda um estímulo capaz de combater os desafios causados pelas sucessivas crises econômicas, as desconfianças sobre os rumos da integração e as críticas formuladas pela nova onda de europessimistas, capitaneada por pensadores do quilate de Mazower. ${ }^{140}$

Se for correto afirmar que a exaltação dos poderes do "Estado Nação" contribuiu para os horrores da guerra, do genocídio e do apogeu dos regimes totalitários, torna-se compreensível concluir que o novo caminho sedimentou-se no sentido oposto, forjado pela

\footnotetext{
${ }^{138}$ Os principais fundadores do direito internacional clássico discorreram sobre o assunto. Por todos, Gentilli: "As partes devem estar atentas não apenas às causas que causaram a guerra, mas principalmente às novas que a poderiam renová-la no futuro. O vencedor deve esforçar-se para que aquela paz dure para sempre, porque a natureza da paz é de ser perpétua.” (GENTILI, Alberico. O direito de guerra. Tradução de Ciro Mioranza. IJUI, RS: Unijuí, 2005. p. 465). A respeito do contexto internacional, projetos e experiências de união na Europa, recomenda-se a leitura do capítulo 1 da parte preliminar do livro: CASELLA, Paulo Borba. Comunidade Europeia e seu ordenamento jurídico. São Paulo: LTr, 1994. p. 49-90.

139 "E a própria Comunidade é apenas uma etapa rumo a formas de organização do mundo de amanhã." (MONNET, Jean. Memórias: a autobiografia de um dos pais fundadores da União Europeia. Tradução de Alexandra Costa e Sousa e Nuno Fonseca. Lisboa: Ulisseia, 2006. p. 652).

${ }^{140}$ MAZOWER, Mark. O continente das trevas: o século XX na Europa. Coimbra: Edições 70, 2014. p. 455. $\mathrm{O}$ autor critica, por exemplo, os rumos tomados pela UE, o déficit democrático de suas instituições e a integração como único meio de preservar a paz no continente. Ele sustenta que os fantasmas do passado (guerras europeias) não são um bom caminho para o futuro (necessária unificação dos países).
} 
colaboração entre os países ${ }^{141}$ e preservação de certos valores caros à civilização, tutelados por um novo poder supranacional.

Laureada com o prêmio Nobel da $\mathrm{Paz}^{142}$, a União Europeia e os valores que a fundamentam consolidaram-se como modelo de luta pela paz e pela reconciliação, capazes de fazer progredir toda a civilização, por meio da defesa intransigente da democracia, do Estado de Direito, do respeito aos direitos da pessoa humana e das liberdades, inclusive a econômica.

Os seis países ${ }^{143}$ que deram início a essa jornada atribuíram competências às novas instituições criadas para atingir objetivos comuns. Iniciaram pela construção do mercado comum e já atingiram o patamar de união econômica e monetária.

Assim, a União, com o seu modelo supranacional ${ }^{144}$ de integração, tornou-se parte do sistema e do processo constitucional dos Estados membros, bem como "os poderes constitucionais dos Estados membros são a origem da legitimidade da União e dotam-na de um valor e de uma eficiência supranacional". ${ }^{145}$

Se os primeiros tratados firmados ressaltaram a unidade e os princípios de liberdade econômica para alcançar a livre circulação de pessoas, bens, serviços e capitais, como lembram Meinhard ${ }^{146}$ e Soares $^{147}$, a cada reforma foram reforçados, ou incorporados,

\footnotetext{
${ }^{141}$ Como afirma Badura: "A experiência histórica que temos demonstra que a associação política dos homens num estado é - não obstante as suas deficiências -, por enquanto, a única forma de criar e assegurar a liberdade, a justiça e o bem-estar. A integração europeia é uma nova forma de completar esta garantia através de uma comunidade federal. Esta comunidade restringe mesmo os poderes constitucionais dos Estados membros, mas deve a sua vida à preservação vital do núcleo constitucional dos Estados europeus." (BADURA, Peter. A "identidade nacional" dos Estados Membros na Constituição da Europa. In: CUNHA, Paulo de Pitta e; QUADROS, Fausto de (Orgs.). Uma Constituição para a Europa. Instituto Europeu da Faculdade de Direito de Lisboa, British Council, Goethe-Institut Lissabon, Institut Franco-Portugais. Coimbra: Almedina, 2004. p. 81). No mesmo sentido, Habermas conclui pela impossibilidade dos Estados Nacionais, isolados, acompanharem o passo de uma concorrência globalizada e conclui que há uma alternativa satisfatória apenas no aperfeiçoamento federalista de uma União Europeia capaz de agir em termos de uma política social e econômica e, então, "poder dirigir o olhar para o futuro de uma ordem cosmopolita sensível às diferenças e socialmente equilibrada". (HABERMAS, Jügen. A constelação pósnacional: ensaios políticos. Tradução de Márcio Seligmann Silva. São Paulo: Littera Mundi, 2001. p. 2).

${ }^{142}$ Prêmio Nobel entregue pelo Comitê norueguês, no ano de 2012.

${ }^{143}$ Alemanha, França, Bélgica, Itália, Luxemburgo, Países Baixos.

144 “'C'est pourquoi l'UE n'est ni une organization internationale classique ni une association d'États, mais une entité qui se situe aux croisées de ces formes traditionnelles d'association entre États. En termes juridiques, on parle d'une organisation supranationale." (BORCHARDT. Klaus-Dieter. L'ABC du droit de l'Union Européenne. Luxembourg: Office des publications de l'Union Européenne, 2010. p. 35).

${ }^{145}$ BADURA, Peter. A "identidade nacional" dos Estados Membros na Constituição da Europa. In: CUNHA, Paulo de Pitta e; QUADROS, Fausto de (Orgs.). Uma Constituição para a Europa. Instituto Europeu da Faculdade de Direito de Lisboa, British council, Goethe-Institut Lissabon, Institut Franco-Portugais. Coimbra: Almedina, 2004. p. 74-75.

${ }^{146}$ HILF, Meinhard. Os direitos fundamentais na Constituição Europeia. In: CUNHA, Paulo de Pitta e; QUADROS, Fausto de (Orgs.). Uma Constituição para a Europa. Instituto Europeu da Faculdade de Direito de Lisboa, British council, Goethe-Institut Lissabon, Institut Franco-Portugais. Coimbra: Almedina, 2004. p. 179.
} 
novos princípios e valores, tais como a busca pelo desenvolvimento sustentável e a proteção ao meio ambiente e a ampliação dos direitos e as garantias fundamentais do cidadão europeu.

De Paris a Lisboa, "en passant par Rome, Maastricht, Amsterdam et Nice"148, constituiu-se uma união ${ }^{149}$ : (i) autônoma, dotada de direitos soberanos; (ii) sustentada por pilares singulares que correspondem a uma ordem jurídica própria; e (iii) na qual seus membros reconhecem o primado do direito comunitário sobre o direito nacional.

(i) A União Europeia constitui uma ordem jurídica de direito interno e internacional, a favor da qual os Estados atribuíram ${ }^{150}$ competências muito superiores às vivenciadas nos clássicos acordos firmados entre países, abrangendo domínios bastante arraigados à ideia de soberania: a defesa do território, a potestade tributária e o direito à cidadania.

A UE tem personalidade jurídica e poder para celebrar tratados internacionais com terceiros países ou organizações internacionais ${ }^{151} \mathrm{e}$, nos domínios que não são de sua

${ }^{147}$ SOARES, António Goucha. A carta dos direitos fundamentais da União Européia: a proteção dos direitos fundamentais no ordenamento comunitário. Coimbra: Coimbra Editora, 2002. p. 10.

148 BORCHARDT. Klaus-Dieter. L'ABC du droit de l'Union Européenne. Luxembourg: Office des publications de l'Union Européenne, 2010. p. 9.

${ }^{149}$ A natureza jurídica da União Europeia foi construída fundamentalmente a partir da combinação de dois acórdãos do Tribunal da Comunidade, os célebres processos Van Gend \& Loos e o Da Costa/Enel. Posteriormente, os princípios decorrentes desses julgamentos foram parcialmente incorporados aos Tratados da UE. Na opinião de Paulo de Pitta e Cunha, classificar a UE como uma instituição sui generis é algo ultrapassado: "Historicamente, pelo menos, a UE é uma organização internacional e, de acordo com alguns critérios, poderia ser classificada como uma confederação, mas também tem muitos atributos de uma federação, sendo que alguns chegam a classificá-la como uma federação (de facto) de Estados. Por esta razão, a organização, no passado, foi denominada como uma instituição sui generis (única em seu gênero), embora também se argumente que esta designação não é mais verdadeira atualmente." (CUNHA, Paulo de Pitta e. Tratado ou Constituição? In: CUNHA, Paulo de Pitta e; QUADROS, Fausto de (Orgs.). Uma Constituição para a Europa. Instituto Europeu da Faculdade de Direito de Lisboa, British council, GoetheInstitut Lissabon, Institut Franco-Portugais. Coimbra: Almedina, 2004. p. 45-49). Pode-se afirmar, com segurança, é que a UE goza de existência própria, caráter permanente, vontade distinta dos seus membros e autonomia de atuação (SOARES, Mário Lúcio Quintão. Mercosul: direitos humanos, globalização e soberania. 2. ed. rev., atual. e ampl. Belo Horizonte: Del Rey, 1999).

${ }^{150} \mathrm{O}$ artigo $5^{\circ}$, inciso 2 estabelece: "A União atua unicamente dentro dos limites das competências que os Estados-membros lhe tenham atribuído nos Tratados para alcançar os objetivos fixados por estes últimos. As competências que não sejam atribuídas à União nos Tratados pertencem aos Estados-membros." (UNIÃO EUROPEIA. Tratado da União Europeia e Tratado sobre o Funcionamento da União Europeia. Luxemburgo: Serviço das Publicações da União Europeia, 2012).

${ }^{151}$ UNIÃO EUROPEIA. Tratado da União Europeia e Tratado sobre o Funcionamento da União Europeia. Luxemburgo: Serviço das Publicações da União Europeia, 2012. Artigos 37 e 47. 
competência exclusiva, é regida pelos princípios da subsidiariedade $^{152}$ e da proporcionalidade. $^{153}$

(ii) A ordem jurídica própria decorre do quadro institucional sólido e permanente, comprometido com a defesa dos seus valores e objetivos, capaz de dar continuidade às políticas e ações comunitárias, bem como assegurar uma interpretação uniforme do seu direito material.

As sete ${ }^{154}$ instituições da UE atuam conforme os limites das atribuições que lhe são conferidas pelo Tratado da União Europeia e pelo Tratado sobre o Funcionamento da União Europeia ${ }^{155}$, de acordo com os procedimentos, condições e finalidades estabelecidas nos pactos fundantes.

(iii) A primazia e a aplicação direta do direito comunitário garantem que os fundamentos jurídicos da União não sejam colocados em risco pelos Estados membros, quer seja por desrespeito aos acordos firmados, pela não uniformidade na interpretação, ou ainda, nos casos de conflito com o direito nacional, a oposição de norma interna que pretenda alterar ou revogar a norma europeia. Assim, as obrigações pactuadas são fontes de direitos e obrigação para os seus membros e para os cidadãos dessas coletividades, assegurando o primado do direito da União.

A União Europeia, atualmente composta por vinte e oito países, foi, portanto, erigida pelos tratados internacionais e pelos regulamentos, diretivas, decisões e jurisprudência emanados de suas instituições supranacionais.

Dessa forma, das cinzas da Segunda Guerra Mundial, as três Comunidades ${ }^{156}$ que deram azo à União visaram a restabelecer o crescimento econômico dos países arrasados

${ }^{152}$ O princípio estabelece que a UEo intervém, nos domínios que não são da sua competência exclusiva, apenas se, e na medida em que, os objetivos da ação não possam ser suficientemente alcançados pelos Estados membros (UNIÃO EUROPEIA. Tratado da União Europeia e Tratado sobre o Funcionamento da União Europeia. Luxemburgo: Serviço das Publicações da União Europeia, 2012. art. o , inciso 3).

${ }^{153} \mathrm{O}$ princípio determina que a ação da UE não deve exceder o necessário para alcançar os objetivos dos tratados (UNIÃO EUROPEIA. Tratado da União Europeia e Tratado sobre o Funcionamento da União Europeia. Luxemburgo: Serviço das Publicações da União Europeia, 2012. art.5 ${ }^{\circ}$, inciso 4).

${ }^{154}$ A UE tem sete instituições: o Parlamento Europeu, o Conselho da União Europeia, a Comissão Europeia, o Conselho Europeu, o Banco Central Europeu, o Tribunal de Justiça da União Europeia e o Tribunal de Contas Europeu.

${ }^{155}$ UNIÃO EUROPEIA. Tratado da União Europeia e Tratado sobre o Funcionamento da União Europeia (versão consolidada). Luxemburgo: Serviço das Publicações da União Europeia, 2012.

156 (i) Comunidade Europeia do Carvão e do Aço (CECA): o tratado foi firmado em Paris (1951), concretizando a proposta de Schuman, ministro francês dos negócios estrangeiros. Alemanha, Bélgica, França, Itália, Luxemburgo e Países Baixos (a Europa dos Seis) estabeleceram um mercado comum para o controle do comércio das matérias primas dos artefatos bélicos. A Declaração Schuman, como ficou conhecida, inicia-se assim: "A paz mundial não poderá ser salvaguardada sem esforços criativos que estejam à altura dos perigos que a ameaçam"; (ii) Comunidade Econômica Europeia (CEE): instituída pelo Tratado de Roma (1957). Os mesmos seis países europeus compuseram um acordo que criou o poder supranacional da Comunidade e estabeleceram o compromisso de implementar um mercado comum, além 
pelos conflitos bélicos e assegurar a capacidade de concorrência com as economias dos países que emergiram fortalecidos após o conflito. ${ }^{157}$

Um dos feitos mais notáveis do sonho europeu foi a realização do mercado comum, como afirma Fontaine, "le marché intérieur est l'une des plus grandes réussites de l'Union européenne ${ }^{158}$. Ao consagrar a liberdade de circulação de pessoas, bens, serviços e capitais em seu território, tornou possível o sonho de paz e união do continente, dando início a uma nova história.

E a história do mercado comum confunde-se com a própria história da União.

\subsection{O mercado comum europeu e os esforços para a harmonização da tributação indireta}

A história da formação do mercado comum europeu pode ser contada pelos tratados (direito primário ou originário) e pelos atos emanados das instituições responsáveis pela integração (direito secundário ou derivado), em especial as diretivas do Conselho e a jurisprudência do Tribunal de Justiça.

As fases de harmonização da tributação indireta podem ser descritas como segue.

\subsubsection{Primeira fase: o Tratado de Roma e as diretivas do Conselho}

\subsubsection{O Tratado de Roma}

O Tratado de Roma (1957) ${ }^{159}$ que instituiu a Comunidade Econômica Europeia (CEE) elegeu como missão a progressiva, contínua e equilibrada aproximação das políticas econômicas dos Estados membros, mediante o estabelecimento de um mercado comum que

\footnotetext{
de avançar na cooperação social e política e econômica; (iii) Comunidade Europeia da Energia Atômica (Euratom): estabelecida pelo Tratado de Roma (1957), com o objetivo de coordenar os programas de utilização pacífica da energia nuclear.

157 “O princípio motor e a legitimidade da União resultam do fato de o Estado, pela mera mobilização dos seus recursos vitais, ser incapaz de salvaguardar e garantir a liberdade, a justiça e o bem-estar, devido ao desenvolvimento econômico e político na Europa e às relações globais." (BADURA, Peter. A "identidade nacional" dos Estados Membros na Constituição da Europa. In: CUNHA, Paulo de Pitta e; QUADROS, Fausto de (Orgs.). Uma Constituição para a Europa. Instituto Europeu da Faculdade de Direito de Lisboa, British council, Goethe-Institut Lissabon, Institut Franco-Portugais. Coimbra: Almedina, 2004. p. 74).

158 FONTAINE, Pascoal. Comprendre les politiques de l'Union Européenne: 12 leçons sur l'Europe. Luxembourg: Office des publications de l'Union européenne, 2014. p. 21.

159 COMMUNAUTÉ ÉCONOMIQUE EUROPÉENNE. Traité instituant la Communauté Économique Européenne. Roma, 1957.
} 
deveria ser erigido no período de quinze anos, consideradas as prorrogações autorizadas pelo acordo. ${ }^{160}$

O Tratado foi estruturado de forma a estabelecer, nos prazos acordados, os objetivos a serem alcançados e o papel de cada instituição criada, mediante o firme compromisso dos Estados em adotar as medidas previstas no direito primário ou oriundas do direito derivado, devendo se abster de qualquer ato que pudesse colocar em perigo a realização da integração. ${ }^{161}$

A estrutura institucional da CEE era composta pelos seguintes órgãos: Assembleia ${ }^{162}$, Conselho ${ }^{163}$, Comissão ${ }^{164}$ e Tribunal de Justiça ${ }^{165}$, que detinham poderes para atuar dentro dos limites das competências atribuídas pelos países fundantes. A Comissão e o Conselho eram assistidos por um Comitê Econômico e Social ${ }^{166}$, composto por representantes dos diferentes setores da vida econômica e social dos Estados membros, com funções consultivas.

No curso do processo de decisão, o exercício legislativo decorria da atuação conjunta da Assembleia, da Comissão e do Conselho, cabendo a este último a formulação de regulamentos ${ }^{167}$, diretivas ${ }^{168}$, decisões ${ }^{169}$, recomendações ou pareceres ${ }^{170}$ direcionados aos países integrantes da CEE.

${ }^{160}$ O Tratado de Roma entrou em vigor em 1958, portanto, o mercado comum deveria estar plenamente constituído em 1973 (arts. $1^{\circ}$ a $8^{\circ}$ ).

${ }^{161} \mathrm{O}$ prazo estabelecido pelo Tratado era de doze anos, admitindo-se a prorrogação por mais três anos (art. $\left.5^{\circ}\right)$.

${ }_{162}$ A Assembleia, composta por representantes do povo de cada um dos Estados membros, exercia a competência de deliberação e de controle atribuídas pelo Tratado (arts. 137 a 144).

${ }^{163}$ Ao Conselho competia assegurar a coordenação das políticas econômicas gerais dos Estados membros, com poder de decisão. Era composta pelos representantes dos Estados membros, sendo que cada governo estava representado por um de seus membros. Após ouvir a Comissão, o Conselho editava regulamentos, diretivas, decisões, recomendações e pareceres (arts. 145 a 154).

${ }^{164}$ A Comissão tinha o objetivo de garantir o funcionamento e o desenvolvimento do mercado comum, velava pela aplicação das disposições do Tratado, assim como as disposições adotadas pelas instituições, formulava recomendações sobre matérias de interesse do mercado comum e dispunha de poder de decisão. O Conselho e a Comissão sempre trabalhavam em conjunto, consultando-se mutuamente (arts. 155 a 163).

165 O Tribunal de Justiça garantia o respeito ao direto na interpretação e aplicação do Tratado e dos atos emanados das instituições. Interessante notar que os Estados firmaram o compromisso de não submeter as controvérsias relativas à interpretação ou aplicação do Tratado de Roma a um procedimento de solução distinto dos previstos no acordo (arts. $4^{\circ}$ e 164 a 188).

166 Artigos 193 a 198 do Tratado.

${ }^{167}$ Os regulamentos tinham um alcance geral, eram obrigatórios em todos os seus elementos e diretamente aplicáveis em cada Estado membro (arts. 164 a 188 do Tratado).

${ }^{168}$ As diretivas obrigavam os Estados membros no tocante ao resultado que deviam alcançar, deixando às autoridades nacionais a eleição da forma e dos meios (art. 189). A jurisprudência que se formou sobre o tema informa que a diretiva gozava de aplicabilidade direta no ordenamento jurídico do Estado membro se a obrigação era incondicional e suficientemente precisa (sentença RATTI, de 05.04.1979; sentença REWE, de 07.07. 1981; sentença Moormann, de 20.09.1988; e sentença Prefeitura de Milão - Contrato público de obra - Oferta anormalmente baixa, de 22.06. 1989 (MATTERA, Alfonso. El mercado único europeo: sus reglas, su funcionamento. Traducción al castellano por Cora Zapico Landrove. Madrid: Cívitas, 1991. p. 210). 
Esse período inaugural, denominado transitório, foi dividido em três etapas de quatro anos cada, sujeito a um rígido controle institucional que apurava, ao término de cada período, se os objetivos estabelecidos e as obrigações assumidas haviam sido alcançados, com poderes para agir e fazer valer a vontade manifestada no acordo.

Cientes das dificuldades que os países enfrentariam, o texto fundante admitiu medidas de salvaguarda importantes, a serem adotadas durante o período transitório, para os setores econômicos do membro solicitante, desde que comprovada a necessidade do ajuste para promover o reequilíbrio ou a adaptação ao mercado comum. ${ }^{171}$

As instituições criadas também deveriam velar para que não restasse comprometida a estabilidade financeira ${ }^{172}$ dos Estados membros e, além das medidas de salvaguarda, previu-se a criação do Fundo Social Europeu (com objetivo de melhorar as possibilidades de emprego dos trabalhadores e contribuir para a elevação de seu nível de vida) e a constituição de um Banco Europeu de Inversões (destinado a facilitar a expansão econômica da Comunidade, mediante a criação de novos recursos, autorizado a conceder empréstimos e socorrer os países integrantes).

O primeiro objetivo a ser alcançado era a constituição de uma união aduaneira, mediante: (i) a supressão dos direitos aduaneiros e das restrições quantitativas à entrada e saída de mercadorias, assim como quaisquer outras medidas de efeito equivalente; (ii) definição de uma tarifa externa e de uma política comuns para ser aplicada a terceiros países não integrantes da Comunidade; e (iii) consagração da livre circulação de mercadorias no território da CEE, incluindo as mercadorias originárias dos países da Comunidade ou procedentes de terceiros países que se encontrassem em livre prática ${ }^{173}$ nos Estados membros. ${ }^{174}$

A redução dos direitos aduaneiros, as limitações quantitativas à exportação e os encargos de efeito equivalente deveriam ser concluídos até o final da primeira etapa e competia ao Conselho, por maioria qualificada, definir os ajustes para a harmonização interna da pauta comum ${ }^{175}$. Nesse quesito, a evolução da integração foi muito bem

\footnotetext{
${ }^{169}$ A decisão era obrigatória em todos os seus elementos para todos os destinatários (art. 189).

${ }^{170}$ As recomendações e os ditames não eram vinculantes (art. 189).

${ }^{171}$ Artigo 226 do Tratado de Roma.

172 Artigo $6^{\circ}$ do Tratado de Roma.

${ }^{173} \mathrm{O}$ artigo 10 do tratado estabelece que consideram-se em livre prática os produtos provenientes de países terceiros em relação aos quais se tenham cumprido as formalidades de importação e cobrados os direitos aduaneiros.

${ }^{174}$ Artigo $9^{\circ}$ do Tratado de Roma.

${ }^{175}$ Artigo 21 do Tratado de Roma.
} 
sucedida e a pauta comum passou a ser aplicada integralmente, sem qualquer exceção, ao final do período transitório. ${ }^{176}$

Para assegurar o progresso do mercado comum, a matéria fiscal também recebeu atenção especial no Tratado de Roma, que se ocupou não só de assegurar o princípio da não discriminação ${ }^{177}$, cláusula padrão de qualquer tratado de livre comércio, como proibiu a prática de subvenções fiscais às exportações, ao determinar que, no comércio entre os países da Comunidade, era defeso beneficiar-se de devolução de tributos internos superiores ao montante cobrado nas aquisições antecedentes à exportação. ${ }^{178}$

A preocupação dirigia-se aos países que praticavam impostos sobre o consumo segundo os modelos monofásico ou plurifásico cumulativo (incidência em cascata), hipótese em que o cálculo da devolução de tributos suportados pelo exportador é extremamente complexo e de difícil verificação. ${ }^{179}$

Prevendo que a disparidade de modelos de tributação fatalmente culminaria em distorções ao livre comércio intrabloco, atribuiu-se à Comissão a tarefa de preparar estudos sobre a harmonização das legislações relativas aos impostos indiretos. Concluída a análise, caberia ao Conselho, por unanimidade, decidir quais medidas seriam adotadas para a aproximação das legislações. ${ }^{180}$

Iniciou-se assim a consagração da tributação sobre o consumo mediante um modelo de imposto plurifásico, não cumulativo, incidente apenas sobre o valor acrescido por cada sujeito passivo do circuito econômico dos bens e serviços, até desaguar no consumidor final - o verdadeiro contribuinte.

Vivenciou-se também um dos capítulos mais importantes do processo de constituição da União Europeia, considerando que o mercado comum possibilitou o avanço no projeto de integração ${ }^{181}$. É de se notar que a experiência de eleição de um tributo

\footnotetext{
${ }^{176}$ Artigo 23 do Tratado de Roma.

${ }^{177}$ O princípio universalmente consagrado, que determina a vedação de cobrança de gravame, direto ou indireto, superior para os produtos oriundos de outros países, em comparação com a carga tributária vigente para os produtos nacionais similares. Compromisso cumprido ao término da primeira etapa do período transitório.

${ }^{178}$ Artigo 96 do Tratado de Roma.

${ }^{179}$ Para os tributos cobrados de forma plurifásica e não cumulativa, o valor a ressarcir aos exportadores corresponde exatamente ao valor do imposto cobrado pelas aquisições de bens e serviços vinculados ao produto exportado, portanto é um tipo impositivo considerado neutro sob o ponto de vista do mercado externo. Em sentido oposto, o tipo monofásico concentrado no início do circuito econômico ou o plurifásico não cumulativo dificilmente podem ser conferidos com precisão. Por essa razão, para evitar maiores distorções, enquanto não se harmonizasse o tributo sobre o consumo, o Tratado de Roma estabeleceu critérios para determinar os percentuais de reembolso para essas hipóteses, por tipo de produto.

${ }^{180} \mathrm{O}$ instrumento eleito para ser o indutor dessas normas foi a diretiva.

181 Como afirma o Livro Branco da Comissão: "Just as the Customs Union had to precede Economic Integration, so Economic Integration has to precede European Unity. What this White Paper proposes
} 
economicamente viável vivenciada pela Comunidade Econômica Europeia difundiu-se velozmente, atingindo todos os continentes. Estima-se que, atualmente, mais de 130 países adotam um modelo similar ao IVA europeu.

\subsubsection{O direito comunitário: diretivas sobre a tributação do consumo}

Em atendimento ao disposto no Tratado de Roma, nomeadamente os artigos 95 a 99, a Comissão reuniu um comitê de especialistas ${ }^{182}$ para discutir os regimes tributários vigentes nos Estados membros e apontar soluções necessárias para a sua harmonização, em prol da construção do mercado comum.

O trabalho avaliou de forma detalhada a situação econômica e financeira dos países da CEE e apontou as disparidades qualitativas e quantitativas existentes, graduando-os conforme o nível de compatibilidade ou incompatibilidade aos objetivos da integração. Ao cabo, apontou as soluções para alcançar a neutralidade da tributação e afastar as causas dos possíveis desequilíbrios concorrenciais.

O resultado do estudo propôs uma harmonização de certos impostos, especialmente o que incide sobre o consumo de bens e serviços, para assegurar a política de integração.

O Relatório Neumark ${ }^{183}$, como ficou conhecido, recomendou aos países integrantes a extinção da tributação cumulativa e a adoção de um imposto sobre o valor acrescido (IVA). Somente a partir desse pilar seria possível prosseguir na harmonização da norma tributária vigente em cada país, que deveria atingir inclusive a aproximação das alíquotas. $^{184}$

therefore is that the Community should now take a Further step along the road so clearly delineated in the Treaties. To do less would be to fall short of the ambitions of the founders. Of the community, incorporated in the Treaties; it would be to betray the trust invested in us; and it would be to offer the peoples of Europe a narrower, less rewarding, less secure, less prosperous future than they could otherwise enjoy. That is the measure of the challenge which faces us. Let it never be said that we were incapable of rising to it." (COMMISSION OF THE EUROPEAN COMMUNITIES. White paper from the commission to the European Council. Completing the internal market. 1985. Conclusion 222. Disponível em: <http://europa.eu/documents/comm/white_papers/pdf/com1985_0310_f_fr.pdf>. Acesso em: 01 dez. 2014).

${ }^{182}$ Presidida por Fritz Neumark e composta pelos seguintes especialistas em matéria fiscal e econômica: Willy Abers, Alain Barrère, Cesare Cosciani, Joseph Kauffman, Maurice Masoin, Bernard Schendstok, Carl S. Shoup, G. Stammati e Georges Vedel.

183 COMMISSION. COMMUNAUTÉ ÉCONOMIQUE EUROPÉENNE. Rapport du Comité Fiscal et Financier. Luxembourg: Office des Publications Officielles des Communautés Européennes, 1962. p. 1151.

184 “La réforme de la taxe sur le chiffre d'affaires sur la base des príncipes formulés dans le rapport doit être considérée comme la mesure la plus importante etla plus urgente à prendre dans le cadre de la politique d'harmonisation fiscale." (COMMISSION. COMMUNAUTÉ ÉCONOMIQUE EUROPÉENNE. Rapport du Comité Fiscal et Financier. Luxembourg, Office des Publications Officielles des Communautés Européennes, 1962. p. 89). 
Por fim, propôs, para evitar a dupla imposição nas relações intracomunitárias e assegurar a eliminação das fronteiras físicas existentes entre os países que pretendiam se integrar, a adoção da tributação do IVA no país de origem ${ }^{185}$. Entretanto, diante da dificuldade de se harmonizar de imediato todos os critérios da norma do imposto, admitiu que seria possível inaugurar o mercado comum mediante a adoção do princípio da tributação no destino (exportações exoneradas e importações tributadas, conforme regra internacional padrão vigente em todos os países integrantes do GATT/OMC). ${ }^{186}$

As conclusões apresentadas pela Comissão inspiraram a edição das seguintes diretivas do Conselho, na primeira fase de harmonização da tributação indireta.

\section{a) A Primeira Diretiva IVA do Conselho da Comunidade Econômica Européia ${ }^{187}$}

A Primeira Diretiva relativa à harmonização das legislações fiscais dos Estados membros foi publicada no dia 11 de abril de 1967.

O documento destacou que o objetivo essencial do Tratado de Roma impunha que a concorrência entre os países deveria ter características análogas a um mercado interno, o que pressupunha a aplicação de legislações respeitantes aos impostos sobre o volume de negócios que não causassem desequilíbrios concorrenciais e não impedissem a livre circulação das mercadorias e dos serviços no mercado comum.

Como as legislações em vigor nos países da Comunidade não correspondiam às exigências referidas, a harmonização das legislações deveria ser precedida pela adoção de um tipo impositivo idêntico, regido por um sistema comum de imposto sobre o valor acrescido, combinado com a eliminação dos tributos cumulativos. Os Estados membros deveriam adotar esse novo modelo a partir de $1970 .{ }^{188}$

\footnotetext{
${ }^{185}$ Dilema até hoje vivenciado pela União Europeia, que segue sem ser concretizado.

186 "Le Comité fiscal et financier se prononce, en ce qui concerne les accises, em faveur du maintien de la pratique actuelle (principe du pays de destination). Le fait que les frontières fiscales doivent être maintenues est regrettable et cela pour les raisons en particulier d'ordre psychologique mentionnées plus haut, mais il n'enlève presque rien à nos constatations concernant le souhait de principe de voir supprimer les frontières fiscales. En effet, les produits soumis à des accises spéciales ne jouent qu'un role modeste tant pour ce qui est de leur part dans l'ensemble des exportations et des importations que si l'on considère l'importance absolue et relative des courants commerciaux internationaux." (COMMISSION. COMMUNAUTÉ ÉCONOMIQUE EUROPÉENNE. Rapport du Comité Fiscal et Financier, Luxembourg. Office des Publications Officielles des Communautés Européennes, 1962. p. 80).

${ }^{187}$ CONSEIL DES COMMUNAUTÉS EUROPÉENNES. Première Directive du Conseil, du 11 avril 1967. En matière d'harmonisation des législations des États membres relatives aux taxes sur le chiffre d'affaires (67/227/CEE). Journal Officiel des Communautés Européennes, du 14/04/67, p. 1.301-1.303.

${ }^{188}$ Posteriormente prorrogado para 1972, pela Terceira Diretiva. A República Italiana e o Reino da Bélgica comunicaram à Comissão, em 14 de julho de 1969 e 12 de setembro de 1969, respectivamente, não estarem em condições de respeitar a data limite de $1^{\circ}$ de janeiro de 1970 fixada para a introdução do IVA e
} 
A diretiva, seguindo as recomendações da Comissão, definiu que o sistema comum consistia em aplicar um imposto geral sobre o consumo de bens e serviços, incidente sobre o preço desses (base de cálculo), em todas as fases de produção, distribuição e fornecimento ao consumidor (adoção da plurifasia). Afinal, os estudos demonstraram que um imposto sobre o valor acrescido consegue a maior simplicidade e a maior neutralidade se for cobrado da forma mais geral possível e se o seu âmbito de aplicação abranger todas as fases da produção e da distribuição, bem como o setor das prestações de serviços.

Entretanto, de forma equivocada e que ocasionou uma série controvérsias, a diretiva reconheceu que alguns Estados teriam dificuldades para adotar o sistema plurifásico compreendendo também o momento da venda a varejo, já que esse tipo de gravame era incomum para alguns dos integrantes da CEE. Por essa razão, autorizou que o IVA fosse aplicado até o momento da venda no atacado, deixando a cargo dos Estados cobrarem um imposto complementar autônomo nas vendas a varejo. ${ }^{189}$

Cientes de que a harmonização dos impostos sobre o consumo implicaria relevantes modificações nas suas estruturas físcais, com sensíveis consequências orçamentárias, econômicas e sociais, estabeleceu-se que a harmonização das taxas e isenções seriam definidas em uma etapa posterior. ${ }^{190}$

Determinou que em cada transação o imposto calculado fosse deduzido o montante do imposto que tivesse incidido diretamente sobre o custo dos diversos elementos constitutivos do preço (não cumulatividade apurada pelo método subtrativo: débitoscréditos).

Anunciou que uma nova diretiva seria publicada para definir a estrutura e as modalidades de aplicação do sistema comum do imposto sobre o valor acrescido e estabeleceu o prazo para a Comissão apresentar propostas que indicassem de que modo e

\footnotetext{
solicitaram a prorrogação do prazo. A Bélgica alegou razões de ordem conjuntural e orçamentária, enquanto a Itália necessitava de um projeto de reforma geral dos impostos que dependia da aprovação do parlamento, que estabelecia o prazo de 31 de outubro de 1970 para a conclusão dos trabalhos. A Terceira Diretiva então prorrogou o prazo para implementação obrigatória do IVA para $1^{\circ}$ de janeiro de 1972 (CONSEIL DES COMMUNAUTÉS EUROPÉENNES. Troisième Directive du Conseil, du 9 décembre 1969. En matière d'harmonisation des legislations des États members relatives aux taxes sur le chiffre d'affaires - Introduction de la taxe à la valeur ajoutée dans les États members (69/463/CEE). Journal Official des Communautés Européennes, du 20/12/69, p. 34-35).

189 A decisão causou muitos conflitos entre os Estados membros que adotaram medidas muito diferentes e, consequentemente, prejudiciais ao mercado comum. Tal disparate somente foi corrigido no ano de 1977, com a edição da Sexta Diretiva IVA. Para o MERCOSUL, a experiência demonstra que a plurafasia perfeita é condição para o sucesso da harmonização dos impostos indiretos.

${ }^{190}$ Em relação às isenções, elas também causaram sérias deformações na neutralidade do tributo, erro sanado na Sexta Diretiva IVA.
} 
em qual prazo a harmonização dos impostos sobre o consumo atingiria o objetivo da tributação na origem.

\section{b) A Segunda Diretiva do Conselho da Comunidade Econômica Europeia ${ }^{191}$}

Em 14 de abril de 1967 foi publicada a Segunda Diretiva IVA, que teve como objetivo delinear os critérios da norma tributária do imposto que seria adotado pelos Estados membros. Eivada de imprecisões e permissiva em relação às decisões que poderiam ser tomadas pelos Estados, ao ser transporta para o direito interno de cada país, foi revogada em curto tempo.

Os aspectos positivos que podem ser extraídos da norma são o reconhecimento da importância da progressividade na tributação sobre o consumo ${ }^{192}$, a proibição de inclusão do tributo em sua própria base de cálculo e a obrigatoriedade de aplicação da mesma alíquota interna aos produtos importados. ${ }^{193}$

Por outro lado, a indefinição precisa da regra matriz do tributo permitiu que fossem colhidos diversos insucessos, que seriam corrigidos posteriormente pela Sexta Diretiva IVA do Conselho.

Os equívocos, que podem servir de alerta ao processo de harmonização da tributação indireta no MERCOSUL, podem ser assim descritos:

(i) As hipóteses de incidência não foram bem delineadas e o tributo geral, que deveria alcançar a generalidade do consumo de bens e serviços, acabou perdendo força nas

${ }^{191}$ CONSEIL DE LA COMMUNAUTÉ ÉCONOMIQUE EUROPÉENNE. Deuxième Directive du Conseil, du 11 avril 1967. Journal Officiel des Communautés Européennes, du 14/04/1967, p. 1.303-1.312.

${ }^{192}$ Foi sugerida a aplicação seletiva das alíquotas, maiores ou menores em razão da essencialidade das mercadorias e dos serviços, como meio de conferir justiça à tributação. A crítica à regressividade da tributação sobre o consumo é de longa data, entretanto o tema voltou ao centro das discussões mundiais após a publicação de livro de Thomas Piketty em que propõe a criação de um tributo internacional sobre a riqueza acumulada e, segundo ele, progressivo, para que seja justo. Para ele, o instituto da progressividade tributária é um grande instrumento de distribuição da riqueza e o defende na aplicação desse novo tributo porque "a história da distribuição da riqueza jamais deixou de ser profundamente política, o que impede sua restrição aos mecanismos puramente econômicos. Em particular, a redução da desigualdade que ocorreu nos países desenvolvidos entre 1900-1910 e 1950-1960 foi, antes de tudo resultado das guerras e das políticas pública adotadas para atenuar o impacto desses choques. Da mesma forma, a reascensão da desigualdade depois dos anos 1970-1980 se deveu, em parte, às mudanças políticas ocorridas nas últimas décadas, principalmente no que tange à tributação e às finanças. A história da desigualdade é moldada pela forma como os atores políticos, sociais e econômicos enxergam o que é justo e o que não é, assim como pela influência relativa de cada um desses atores e pelas escolhas coletivas que disso decorrem. Ou seja, ela é fruto da combinação, do jogo de forças, de todos os atores envolvidos [...] Contudo, uma conclusão clara surge desde agora: é ilusório pensar que existem, na estrutura do crescimento moderno, ou nas leis da economia de mercado, forças de convergências que conduzam naturalmente a uma redução da desigualdade da riqueza ou a uma estabilização harmoniosa." (PIKETTY, Thomas. O capital do século XXI. Tradução de Monica Baumgarten de Bolle. Rio de Janeiro: Intrínseca, 2014. p. 27 e 367).

${ }^{193}$ Princípio da não discriminação. 
leis internas. A diretiva deixou a cargo dos Estados a tarefa de determinarem a regulamentação relativa à inclusão dos serviços que seriam alcançados pela exação, cuidando apenas de listar, no Anexo B do documento, as dez hipóteses que deveriam ser obrigatoriamente alcançadas pelo imposto.

(ii) No tocante às alíquotas, permitiu que os Estados as definissem livremente, sem estabelecer qualquer parâmetro entre o percentual máximo e mínimo, ou mesmo um percentual padrão, o que culminou com diversas distorções.

(iii) Admitiu-se que era possível reconhecer, a título transitório, certas diferenças entre as modalidades de aplicação do impostos ${ }^{194}$. A disciplina dos regimes especiais de tributação das microempresas e dos produtos agrícolas ficaram a cargo dos Estados, o que causou várias distorções.

(iv) Permitiu-se que os Estados concedessem livremente isenções, comprometendo a neutralidade pretendida.

(v) Em relação à não cumulatividade, restringiram-se os créditos das aquisições de bens e serviços destinados às necessidades do sujeito passivo (denominados de uso e consumo próprios), além de permitir uma série de derrogações, pelos Estados, ao reconhecimento do crédito dos bens destinados ao ativo imobilizado, mesmo aqueles vinculados à atividade da empresa, afetando, de forma descoordenada, o resultado da apuração mensal do imposto.

(vi) Em relação à apuração do imposto, ficou definido que seria mensal, entretanto os países poderiam reduzir ou ampliar esse prazo para trimestral, semestral ou anual, conferindo desigualdade no tratamento da apuração do tributo a pagar.

(vii) Possibilitou-se a exclusão do imposto no momento da entrega de bens efetuada pelo comerciante varejista (plurifasia imperfeita).

(vii) A definição imperfeita do aspecto especial da tributação dos serviços causou muitas divergências entre os Estados e culminou com diversas reclamações dirigidas ao Conselho.

Esses defeitos somente foram corrigidos cinco anos após os relatórios da Comissão apontarem as divergências que o sistema estava causando ao mercado comum.

A França e a Alemanha conseguiram implementar essas regras previstas na primeira fase de harmonização do IVA no ano de 1968, seguidas pelos Países Baixos (1968), Luxemburgo (1970), Bélgica (1972) e Itália (1973).

\footnotetext{
${ }^{194}$ Procedimento também revisto na Sexta Diretiva IVA, já que a experiência comprova que para atingir a neutralidade é necessário limitar os regimes especiais e as medidas de exceção do tributo.
} 
c) A Sexta Diretiva do Conselho (17.05.1977) $)^{195}$

Após a experiência de implementação do IVA em todos os países, e munidos das recomendações da Comissão, o Conselho editou, em maio de 1977, a mais importante diretiva sobre a harmonização do IVA. Os principais critérios insculpidos na norma tributária inspiraram todas as demais normas futuras, e em grande parte ainda permanecem em vigor na norma atual, com pequenos ajustes.

Outro fator relevante que contribuiu para delimitar adequadamente os critérios da norma foi a decisão ${ }^{196}$ de substituir as contribuições financeiras dos Estados membros por recursos próprios das comunidades, dentre os quais os recursos provenientes da arrecadação dos impostos sobre o consumo.

Ao definir um percentual de arrecadação do tributo a ser destinado à Comunidade, tornava-se imperiosa a prática de uma exação bem similar, de modo que a carga fosse de fato suportada de forma isonômica por todos os países.

Dessa forma, a diretiva objetivou definir com mais clareza a hipótese de incidência, o sujeito passivo da obrigação tributária, o lugar das operações tributáveis, o conceito de fato gerador, a exigibilidade do imposto e a base de cálculo.

A primeira medida foi estabelecer que o imposto alcançaria a tributação dos bens e todos os serviços, de modo a alcançar a generalidade almejada. Assim, proibiu que os Estados editassem listas de inclusão ou exclusão de hipóteses sujeitas à tributação.

A definição legal de serviços era bastante abrangente e alcançava qualquer atividade que não correspondesse a uma entrega de bem. Portanto, não se limitava ao conceito civil de obrigação de fazer. Para atender aos reclames dos Estados, estabeleceu que a regra de tributação dos serviços seria regida pelo princípio da tributação na origem (país competente para tributar seria aquele onde estivesse estabelecido o prestador do serviço), entretanto, com atenuações. No tocante à entrega de bens, manteve o princípio da tributação no destino, com a promessa de revisão do modelo, de modo a permitir a supressão das barreiras físicas em futuro próximo.

\footnotetext{
${ }^{195}$ CONSELHO DAS COMUNIDADES EUROPEIAS. Sexta Diretiva do Conselho, de 17 de maio de 1977. Relativa à harmonização das legislações dos Estados-membros respeitantes aos impostos sobre o volume de negócios - sistema comum do imposto sobre o valor acrescentado: matéria colectável uniforme (77/388/CEE). As medidas foram implementadas pelos Estados nas seguintes datas: 1978 na Dinamarca, 1979 na França, Países Baixos, Itália e Irlanda, e em 1980 na Alemanha e Luxemburgo.

${ }^{196}$ Decisão tomada pela Comunidade Econômica Europeia em 21 de abril de 1970. Para financiar o mercado comum, nada mais justo que a receita seja oriunda das próprias operações e prestações geradas nes se novo ambiente.
} 
Decidiu, acertadamente, por estabelecer uma lista comum de isenções, já que os recursos próprios seriam cobrados de modo uniforme, e padronizou as regras dos regimes especiais de tributação que alcançavam a microempresa e a agricultura, evitando as distorções que foram praticadas pelos Estados membros.

No novo sistema comum harmonizou-se o conceito de não cumulatividade, ampliando-se os créditos do contribuinte, ao se adotar o conceito de crédito financeiro, integral e imediato ${ }^{197}$. É fundamental que o regime de deduções seja harmonizado, na medida que tem influência direta no cálculo do tributo a ser recolhido aos cofres públicos.

A apuração mensal passou a ser obrigatória, podendo os Estados definir quando o contribuinte deveria efetuar o recolhimento ao erário.

Prevendo a necessidade de maior diálogo e aproximação dos países envolvidos, a diretiva criou um comitê para discussão permanente do imposto, que desempenharia um papel muito relevante no combate à fraude, na cooperação e troca de informações entre os poderes fiscais dos países da Comunidade.

Quanto ao aspecto quantitativo da norma, inovou-se ao admitir que os descontos e os valores não recebidos na contraprestação da entrega de bens ou da prestação de serviços fossem excluídos da base de cálculo do tributo.

Assim, os aspectos material, pessoal, temporal, espacial e quantitativo da norma restaram bem delineados e protegidos do risco de serem transpostos pelos Estados de forma que prejudicassem as liberdades almejadas no mercado comum.

A Sexta Diretiva vigorou até o ano de 2006 e sofreu vinte e nove alterações, até a publicação da Diretiva 2006/112/CE, que a substituiu.

\subsubsection{Segunda fase: $o$ mercado interno}

\subsubsection{O Livro Branco da Comissão ${ }^{198}$}

\footnotetext{
197 O crédito admitido alcançava os bens e serviços utilizados nas operações ou prestações gravadas, entretanto eram excluídos os gastos que não tivessem um caráter estritamente profissional, tais como os artigos de luxo e recreação. O saldo remanescente era trasladado para o mês seguinte ou devolvido ao contribuinte.

${ }^{198}$ COMMISSION OF THE EUROPEAN COMMUNITIES. White paper from the commission to the European Council. Completing the internal market. 1985. Disponível em: <http://europa.eu/documents/comm/white_papers/pdf/com1985_0310_f_fr.pdf>. Acesso em: 01 dez. 2014.
} 
Em junho de 1985, a Comissão elaborou um Livro Branco para dar um novo impulso ao mercado comum que se encontrava em crise ou em uma encruzilhada ${ }^{199}$, como definiu o relatório do estudo, causada pela recessão do início dos anos $1980 .^{200}$

A recessão havia feito ressurgir uma série de barreiras ao comércio intrabloco, erguidas para proteger os mercados nacionais, as indústrias e os empregos dos cidadãos locais $^{201}$. As metas lançadas pela Comissão, presidida por Jacques Delors, foram sumarizadas em duzentas e setenta e nove sugestões voltadas para a supressão, no prazo de sete anos, de todos os entraves físicos, técnicos e fiscais à livre circulação no espaço da CEE.

O grande desafio proposto pelo trabalho foi a eliminação dos postos aduaneiros nas fronteiras para os países integrantes da CEE, por representarem o exemplo visível da divisão que ainda vigorava na Comunidade e a sua remoção significaria o sinal mais nítido da integração. O desmantelamento das fronteiras interiores, símbolo das divisões e lutas do passado, passaria a ser o signo mais representativo da integração e um acontecimento sem precedentes na história do continente europeu, segundo Mattera. ${ }^{202}$

O Livro Branco versou também sobre a necessidade de eliminação dos entraves técnicos, que haviam crescido muito no ambiente de proteção dos mercados nacionais, consagrando o princípio do reconhecimento mútuo, já desenvolvido pelo Tribunal de Justiça da Comunidade Econômica Europeia. ${ }^{203}$

\footnotetext{
199 "Europe stands at the crossroads. We either go ahead - with resolution and determination - or we drop back into mediocrity. We can now either resolve to complete the integration of the economies of Europe; or, through a lack of political will to face the immense problems involved, we can simply allow Europe to develop into no more than a free trade area." (COMMISSION OF THE EUROPEAN COMMUNITIES. White paper from the commission to the European Council. Completing the internal market. 1985. Conclusion 219: n. Disponível em: <http://europa.eu/documents/comm/white_papers/pdf/com1985_0310_f_fr.pdf>. Acesso em: 01 dez. 2014).

${ }^{200}$ MATTERA, Alfonso. El mercado único europeo: sus reglas, su funcionamento. Traducción al castellano por Cora Zapico Landrove. Madrid: Cívitas, 1991. p. 338.

${ }^{201}$ Nos anos 70/80 houve outros entraves que dificultaram a realização completa do mercado interno. As especificações técnicas, as normas de saúde e de segurança, os controles cambiais e as regulamentações nacionais relativas ao exercício das profissões restringiam, todos eles, a livre circulação de pessoas, de mercadorias e de capitais.

${ }^{202}$ MATTERA, Alfonso. El mercado único europeo: sus reglas, su funcionamento. Traducción al castellano por Cora Zapico Landrove. Madrid: Cívitas, 1991. p. 32.

${ }^{203}$ Princípio de índole jurisprudencial. O princípio do reconhecimento recíproco é fruto da jurisprudência Cassis de Dijon. MATTERA, Alfonso. El mercado único europeo: sus reglas, su funcionamento. Traducción al castellano por Cora Zapico Landrove. Madrid: Cívitas, 1991. p. 32. No mesmo sentido: VEIL, Simone. L'Europe de la responsabilité, Traité de Rome, 25ème Anniversaire, Comissión de las Comunidades Europeas, Bruselas: Comissión, 1982.
} 
Com a abolição dos controles de fronteiras (barreiras físicas), concebidos para assegurar que cada Estado membro pudesse cobrar as receitas na forma de tributação indireta, seria necessário alterar a forma de controle do IVA, ainda cobrado no destino.

A tributação na origem seria conformada mediante ajustes a serem efetuados por uma câmara de compensações, ${ }^{204}$ mecanismo que nunca foi adotado por resistência dos Estados.

Por meio de um acordo político, os Estados membros conseguiram aprovar um regime transitório para as operações intracomunitárias que permitiria cumprir o prazo para abolição das fronteiras, mas manteria o princípio da tributação no destino, com algumas exceções, estabelecidas principalmente pelas Diretivas 91/680/CEE e 92/111/CEE.

\subsubsection{O Ato Único Europeu}

O Ato Único Europeu, que modificou o Tratado de Roma, com o objetivo de impulsionar a integração europeia, foi assinado em Luxemburgo em 17 de fevereiro de 1986 e entrou em vigor no dia $1^{\circ}$ de julho de 1987.

O tratado alterou as regras de funcionamento das instituições europeias, em especial no tocante à tomada de decisões que requeria a unanimidade para a maior parte dos temas de harmonização legislativa, regra que foi modificada, entretanto não atingiu a matéria fiscal e alargou as competências tributárias, em especial no tocante à política externa comum, ao desenvolvimento e ao meio ambiente. ${ }^{205}$

O impulso foi garantido pela inclusão do artigo 8-a, que passou a conceituar o mercado interno como o espaço sem fronteiras internas, no qual a livre circulação das mercadorias, das pessoas, dos serviços e dos capitais seria assegurada. Note-se que o mercado comum previsto no tratado anterior e o mercado interno possuem o mesmo objetivo: consagrar as liberdades entre os países integrantes.

\footnotetext{
204 "Uma câmara de compensação apuraria as situações líquidas que dariam lugar a pagamentos (dos países exportadores líquidos aos países importadores líquidos). A distribuição final de receita pelos vários países, uma vez operadas as compensações e regularizados os saldos, corresponderia à distribuição típica dos impostos no destino." (BASTO, José Guilherme Xavier de. A tributação do consumo e a sua coordenação internacional. Lisboa: Centro de Estudos Fiscais, 1991.p. 142).

${ }^{205}$ Para facilitar a realização do mercado interno, o Ato Único prevê um aumento do número de casos em que o Conselho pode deliberar por maioria qualificada e não por unanimidade. Essa medida facilita a tomada de decisões, evitando bloqueios inerentes à procura de obtenção de um acordo unânime por parte dos EstadosMembros. A unanimidade deixa de ser necessária para as medidas com vista ao estabelecimento do mercado interno, com exceção das medidas relativas à fiscalidade, à livre circulação das pessoas e aos direitos e interesses dos trabalhadores assalariados.
} 
A nova denominação tinha como objetivo reforçar a necessidade de remoção efetiva das barreiras físicas, técnicas e fiscais ainda remanescentes ${ }^{206}$. A meta era alcançar esse mercado único em 1992, por meio de um programa e calendários obrigatórios.

Por fim, o acordo modificou o artigo 99 do Tratado de Roma, no sentido de reforçar o papel das instituições no processo de harmonização da tributação indireta, considerando que os passos dados já haviam contribuído para a construção do mercado comum, entretanto precisavam continuar avançando.

A grande contribuição do Ato Único Europeu foi permitir a progressão do mercado comum e a eliminação das fronteiras em janeiro de 1993, bem como a criação de novas competências comunitárias e a reforma das instituições, preparando o terreno para a integração política e para a união econômica e monetária, posteriormente instituídas pelo Tratado de Maastricht.

\subsubsection{Alterações na Sexta Diretiva: Diretiva 91/680/CEE}

A Sexta Diretiva foi alterada para contemplar uma nova hipótese de incidência: as operações intracomunitárias de bens e serviços. Já que não seria possível adotar a tributação na origem, mas também não seria possível, em razão da supressão das barreiras físicas, exigir o tributo nas aduanas de destino, estabeleceu-se um regime provisório para que o imposto pudesse ser exigido em momento posterior à entrada no país comunitário de destino (distinto do desembaraço aduaneiro na hipótese de importação de terceiros países). Para tanto, a operação do remetente não seria gravada pelo imposto, entretanto estaria sujeita à confirmação de recebimento pelo destinatário localizado no outro Estado membro e comprovação do recolhimento do tributo.

Após a assinatura dos Tratados de Maasctricht (1992), Amsterdam (1997), Nice (2001) e Lisboa (2007), a estrutura delineada pelo Livro Branco, a regra matriz de incidência elaborada pela Sexta Diretiva e a exigência de unanimidade para definir as questões fiscais no Conselho permaneceram intocadas.

\footnotetext{
${ }^{206}$ A noção ampla de mercado comum foi confirmada pela jurisprudência do tribunal, em particular na sentença Schul, de 5 de maio de 1982: "La noción de mercado comum, delimitada por uma reiterada jurisprudencia, comprende la eliminación de todas las trabas a los intercambios intracomunitarios con vistas a la fusión de los mercados nacionales en un mercado único que funcione en condiciones lo más similares posible a las de un verdadero mercado interior." (MATTERA, Alfonso. El mercado único europeo: sus reglas, su funcionamento. Traducción al castellano por Cora Zapico Landrove. Madrid: Cívitas, 1991. p. 42).
} 
A atual diretiva que rege o IVA é a Diretiva 2006/112/CE, que nada mais é que uma recompilação de todas as alterações sofridas ao longo do tempo pela Sexta e mais famosa de todas elas.

A Comissão tem se preocupado atualmente com a simplificação das obrigações fiscais, a consolidação da legislação existente sobre o tema e o combate à fraude, pelo menos enquanto o projeto de adoção do princípio de origem para as operações intracomunitárias foi abandonado ou postergado. ${ }^{207}$

\subsection{O Imposto sobre o Valor Acrescido (IVA): expoente da acquis communautaire}

Na União Europeia, uma das primeiras medidas adotadas no processo de unificação foi a exigência de implementação de um amplo imposto sobre o consumo, plurifásico, neutro e incidente sobre o valor acrescido em cada operação.

Inspirado no modelo francês de tributação, o IVA substituiu os impostos cumulativos existentes nos Estados membros e a conclusão a que se pode chegar é que na construção do mercado único europeu, para se implementar as grandes liberdades, foi necessária a harmonização das legislações tributárias, notadamente em relação aos impostos incidentes sobre o consumo e, para tanto, os países membros foram obrigados a adotar o mesmo modelo de tributação do consumo de bens e serviços.

O imposto vigente em todos os vinte e oito países que hoje integram a União Europeia guarda as seguintes características: ${ }^{208}$

(i) O IVA é um imposto geral sobre o consumo, instituído pelo poder central e alcança as atividades de importação, produção, comercialização de bens e a prestação de serviços.

(ii) Os critérios da norma tributária encontram-se definidos nas diretivas do Conselho, normas supranacionais que vinculam todos os Estados membros. Compete ao Estado inovar apenas nos domínios não disciplinados pelas diretivas, como, por exemplo, definir a data de recolhimento do tributo e atribuir capacidade para fiscalização e cobrança a outros entes do país.

\footnotetext{
207 SANTOS, António Carlos dos. Implicações do processo de integração de Portugal na Comunidade Europeia nas políticas fiscal e orçamental. In: SARAIVA FILHO, Oswaldo Othon de Pontes; VASQUES, Sérgio; GUIMARÃES, Vasco Branco (Org.). IVA para o Brasil: contributos para a reforma da tributação do consumo. Belo Horizonte: Fórum, 2007. p. 221-258. p. 251.

${ }^{208}$ Diretiva 2006/112/CE do Conselho, de 28 de novembro de 2006, relativa ao sistema comum do imposto sobre o valor acrescentado.
} 
(iii) $\mathrm{O}$ tributo é calculado a cada etapa da produção, comercialização bens e prestação de serviços, incidindo sobre o valor acrescentado na cadeia pelos operadores do imposto.

(iv) O valor do tributo a recolher aos cofres públicos é decorrente da diferença entre débitos (apurados pelas vendas) menos créditos (apurados pelas compras), o que lhe confere o caráter não cumulativo. $\mathrm{O}$ universo de créditos é de natureza financeira, abrange as aquisições de bens e serviços vinculados às saídas tributadas. Esse mecanismo confere ao sistema plurifásico a neutralidade necessária, pois o número de operações existentes até o consumidor final torna-se irrelevante para caracterizar ou diferenciar o valor do encargo devido ao sujeito ativo.

(v) O modelo assegura que o IVA seja suportado em definitivo pelo consumidor final; pelo mecanismo de preços, o tributo devido em cada fase é incorporado ao valor a ser cobrado do destinatário. No preço final do produto, a soma dos valores acrescidos é repassada ao preço e esse valor corresponde exatamente ao valor resultante da aplicação da alíquota do produto sobre a base de cálculo da última operação, considerando-se que o recolhimento efetuado por cada contribuinte foi feito de forma fracionada, mediante a sistemática da não cumulatividade (anestesia fiscal) ${ }^{209}$.

(vi) Encontram-se sujeitas ao tributo as operações efetuadas a título oneroso no território de um Estado membro por um sujeito passivo e também as importações efetuadas por qualquer pessoa, quer seja um contribuinte habitual ou não.

(vii) O tributo também alcança as aquisições intracomunitárias de bens efetuadas por um sujeito passivo, ocorrendo a tributação no país de destino, salvo as exceções previstas nas diretivas. Nas aquisições de serviços, o imposto poderá ser cobrado na origem ou no destino, dependendo da natureza do serviço, conforme as hipóteses delineadas na diretiva. ${ }^{210}$

\footnotetext{
209 "Eis, pois, duas características fundamentais do IVA que o tornam particularmente virtuoso e especialmente apatecível: trata-se de um imposto geral sobre o consumo que, actuando através do método subtrativo indirecto nas diversas fases do circuito económico, teoricamente apenas sobre o valor acrescentado em cada uma delas, provoca o chamado efeito de anestesia fiscal." (PALMA, Clotilde Celorico. A harmonização comunitária do imposto sobre o valor acrescentado: quo vadis? In: SARAIVA FILHO, Oswaldo Othon de Pontes; VASQUES, Sérgio; GUIMARÃES, Vasco Branco (Org.). IVA para o Brasil: contributos para a reforma da tributação do consumo. Belo Horizonte: Fórum, 2007. p. 175-220. p. 176).

${ }^{210}$ No exercício de combate à fraude no IVA, o Conselho estabeleceu a obrigatoriedade de recolhimento antecipado do imposto devido no destino. A partir de 1 de janeiro de 2013, quando a Diretiva 2010/45/UE entrou em vigor, o imposto tornou-se exigível no momento da emissão da fatura.
} 
(viii) O sujeito passivo da obrigação tributária é aquele que exerce de modo independente $^{211}$ uma atividade econômica ${ }^{212}$. Contribuintes, portanto, são os produtores, os comerciantes, os prestadores de serviços, os extratores, os profissionais liberais e os equiparados pela legislação (assimilados).

(ix) A entrega de bens é a transferência do poder de dispor de um bem corpóreo como proprietário.

(x) Entende-se por prestação de serviço qualquer operação que não constitua uma entrega de bens.

(xi) A aquisição intracomunitária de bens é a obtenção do poder de dispor, como proprietário, de um bem móvel corpóreo transportado de um Estado membro, com destino ao adquirente noutro Estado membro.

(x) A importação é a introdução na UE de um bem que não se encontre em livre prática de comércio nenhum dos Estados membros.

(xi) Em relação aos bens, ocorre o fato gerador no lugar onde ele se encontra no momento da entrega, exceto nas aquisições intracomunitárias, cujo lugar para a ocorrência do fato gerador é designado no momento da chegada do transporte ao adquirente. Nas importações de terceiros países, o fato gerador ocorre no desembaraço aduaneiro (postos de fronteira).

(xii) $\mathrm{O}$ fato gerador da prestação de serviço ocorre no lugar onde o prestador tem a sede de sua atividade econômica ou o domicílio, entretanto, há hipóteses em que o fato gerador ocorre no local da efetiva prestação, tais como serviços relacionados a bens imóveis, ao transporte de passageiros e bens, a atividades culturais, artísticas, desportivas, científicas, docentes e recreativas.

(xiii) A base de cálculo compreende todos os valores que constituem a contraprestação pela entrega do bem ou pelo serviço prestado, com exceção do próprio imposto, portanto é um tributo calculado "por fora". Nas importações de terceiros países, a base de cálculo é acrescida dos tributos e despesas aduaneiras.

(xiv) As alíquotas do imposto são definidas pelos Estados membros, entretanto as diretivas determinam que a alíquota padrão deva ser superior a $15 \%$ (vigente até 31.12.2015) e admite a possibilidade dos Estados praticarem duas outras alíquotas

\footnotetext{
${ }^{211} \mathrm{Na}$ medida que os assalariados e outras pessoas se encontrem vinculados à entidade patronal por um contrato de trabalho ou por qualquer outra relação jurídica que estabeleça vínculos de subordinação, as suas atividades não se consideram como sendo exercidas de modo independente.

212 Qualquer outra pessoa que efetue a título ocasional uma entrega de um meio de transporte novo transportado com destino a outro Estado membro é considerada também um sujeito passivo.
} 
reduzidas, não inferiores a 5\% para os bens e serviços essenciais (previstos no Anexo III da Diretiva 2009/47/CE).

(xv) As isenções são concedidas de forma coordenada e encontram-se previstas nas diretivas do Conselho. As isenções, via de regra, não permitem que sejam reconhecidos os créditos das aquisições vinculadas a saída isenta, entretanto há previsões de manutenção desses créditos quando a saída isenta se relacionar a entregas intracomunitárias de bens e a exportações de bens da UE para um país terceiro.

(xvi) Os regimes especiais são regidos pelas diretivas e alcançam as seguintes hipóteses: pequenas empresas, produtores agrícolas, bens de segunda mão, objetos de arte, de coleção e antiguidades, ouro para investimento, agências de viagem, serviços prestados por via eletrônica.

(xvii) Princípio da origem x princípio do destino: nas relações com terceiros países, o IVA submete-se ao princípio do país de destino. Dessa forma, as exportações são livres de impostos e as importações sujeitam-se ao imposto, e a carga tributária aplicada é a prevista para os bens e serviços que circulam no interior do país importador. No tocante às operações intracomunitárias, em tese, o princípio deveria ser o da origem, conforme estabelecia o tratado de Roma. Entretanto, a regra vigente é mista: a) para a entrega de bens, a regra geral é a do destino, entretanto há exceções bem delineadas na Diretiva IVA. b) para a prestação de serviço, a regra geral é a da origem, com atenuações também descritas na Diretiva IVA.

(xviii) Por fim, o IVA, embora seja um tributo geral que objetiva alcançar todas as entregas de bens serviços, pode conviver com impostos especiais sobre o consumo ${ }^{213}$, entretanto a harmonização (definição de todos os critérios da norma) também deve ocorrer, para evitar conflitos com o imposto sobre o valor agregado.

\section{Regra-matriz do IVA nas operações e prestações internas}

\begin{tabular}{|ll|}
\hline Hipótese: & \\
\hline Critério material & Entrega de bens ou prestação de serviços \\
Critério espacial & Âmbito territorial do Estado \\
Critério temporal & Momento da venda ou da prestação do serviço
\end{tabular}

\footnotetext{
${ }^{213}$ Produtos sujeitos a impostos especiais de consumo na UE: produtos energéticos, álcool e bebidas alcoólicas e tabaco manufaturado, tal como definidos pelas disposições comunitárias em vigor, com exceção do gás fornecido por uma rede de gás natural situada no território da UE ou por qualquer rede a ela ligada.
} 


\begin{tabular}{|c|c|c|}
\hline \multicolumn{3}{|l|}{ Consequentes: } \\
\hline \multirow[t]{2}{*}{ Critério pessoal } & Sujeito ativo: & O Estado \\
\hline & Sujeito passivo: & $\begin{array}{l}\text { Industriais, comerciantes, extratores, produtores e prestadores } \\
\text { de serviços }\end{array}$ \\
\hline \multirow[t]{3}{*}{ Critério quantitativo } & Base de cálculo: & $\begin{array}{l}\text { O valor da operação de venda ou da prestação de serviços, } \\
\text { sem a inclusão do próprio imposto }\end{array}$ \\
\hline & Alíquota: & Padrão- mínima: 15\%, Reduzida- mínima: 5\% \\
\hline & $\begin{array}{l}\text { Tributo } \\
\text { recolher: }\end{array}$ & $\begin{array}{l}\text { Resultado do confronto de débitos - créditos apurados no } \\
\text { mês. Tributo sujeito a não cumulatividade. }\end{array}$ \\
\hline
\end{tabular}

\section{Regra-matriz do IVA nas transações intracomunitárias}

\begin{tabular}{|ll|}
\hline Hipótese: & Adquirir bens e determinadas prestações de serviços \\
\hline Critério material & No território do Estado-membro adquirente \\
Critério temporal & $\begin{array}{l}\text { No momento da entrada do bem no estabelecimento do adquirente ou na prestação } \\
\text { do serviço em seu território }\end{array}$ \\
\hline
\end{tabular}

\section{Consequentes:}

$\begin{array}{lll}\text { Critério pessoal } & \text { Sujeito ativo: } & \text { O Estado adquirente } \\ & \text { Sujeito passivo } & \text { Adquirente } \\ \text { Critério quantitativo } & \text { Base de cálculo } & \text { O valor da operação ou prestação, excluído o próprio imposto } \\ & \text { Alíquota } & \text { Padrão- mínima: } 15 \%, \text { Reduzida- mínima: } 5 \% \\ & \text { Tributo a recolher } & \text { Conforme definido pelas diretivas }\end{array}$

\section{Regra-matriz do IVA na importação de terceiros países}

\begin{tabular}{|ll|}
\hline Hipótese: & \\
\hline Critério material & Importar bens do exterior; Importar determinados serviços do exterior \\
Critério espacial & Repartições alfandegárias \\
Critério temporal & O momento do pagamento dos tributos aduaneiros \\
\hline
\end{tabular}

\begin{tabular}{|c|c|c|}
\hline \multicolumn{3}{|l|}{ Consequentes: } \\
\hline \multirow[t]{2}{*}{ Critério pessoal } & Sujeito ativo: & O Estado \\
\hline & Sujeito passivo & Importador, inclusive os particulares \\
\hline \multirow[t]{3}{*}{ Critério quantitativo } & Base de cálculo & $\begin{array}{l}\text { O preço que servir de base para o cálculo dos tributos } \\
\text { aduaneiros, acrescido do montante destes e exclusão do } \\
\text { próprio imposto }\end{array}$ \\
\hline & Alíquota & Aquela prevista para o similar nacional \\
\hline & Tributo a recolher & Devido no momento do pagamento dos tributos aduaneiros \\
\hline
\end{tabular}




\subsection{As reformas dos sistemas tributários em Portugal e na Alemanha: reflexões para o MERCOSUL}

\subsubsection{República Portuguesa}

A adoção do sistema comum do IVA, regulado pelas diretivas do Conselho, é obrigatória para a adesão à Comunidade Econômica Europeia (CEE). As negociações para a entrada de Portugal na CEE estabeleceram que o país ingressaria no ano de 1986, devendo adotar o acervo comunitário fiscal em até três anos. Entretanto, a prorrogação negociada não foi necessária e o país adotou o IVA de matriz comunitária no mesmo ano de sua adesão. ${ }^{214}$

A antecipação do prazo assentou-se nos próprios méritos do IVA, em confronto com o sistema de tributação do consumo em Portugal, que já apresentava uma série de problemas internos.

Segundo Jaime Devesa, o IVA respondia bem às necessidades de reforma da tributação indireta, porque no sistema cumulativo as distorções ao funcionamento do mercado tornaram-se intoleráveis e o regime monofásico praticado pelo país incapacitava o crescimento das receitas e favorecia a evasão e fraudes fiscais. ${ }^{215}$

Segundo Basto, os problemas tributários não constituíram questões de grande sensibilidade e dificuldade nas negociações de adesão da República Portuguesa à CEE, mas o sistema tributário nacional era ainda significativamente diferente do modelo adotado pela Comunidade. ${ }^{216}$

Vigorava em Portugal um imposto sobre transações (IT), monofásico, implantado na produção industrial e no comércio atacadista. Era um imposto parcialmente não cumulativo e usava a técnica do anel (ring system), a qual assegura que as transações entre contribuintes registrados não sejam tributadas, evitando a cumulação de impostos nas

\footnotetext{
${ }^{214}$ BASTO, José Guilherme Xavier de. Adopção do sistema comum europeu de Imposto sobre o Valor Acrescentado (IVA) em Portugal. In: SARAIVA FILHO, Oswaldo Othon de Pontes; VASQUES, Sérgio; GUIMARÃES, Vasco Branco (Org.). IVA para o Brasil: contributos para a reforma da tributação do consumo. Belo Horizonte: Fórum, 2007. p. 89.

${ }^{215}$ DEVESA, Jaime. IVA: Código do Imposto sobre o Valor Acrescentado. Coimbra, Portugal: Almedina, 2003. p. 37.

${ }^{216}$ DEVESA, Jaime. IVA: Código do Imposto sobre o Valor Acrescentado. Coimbra, Portugal: Almedina, 2003. Artigo 90, p. 43.
} 
operações intermediárias, entretanto sem muito sucesso. Esse mecanismo de suspensão do imposto, uma das linhas mestras do sistema, era um caminho aberto à fraude. ${ }^{217}$

A base de incidência não era muito ampla: poucos serviços eram alcançados e o país praticava um número muito grande de isenções, principalmente para os bens essenciais.

Dessa forma, o Código do IVA português foi publicado quando Portugal ainda era país candidato à adesão, pelo Decreto-Lei n. 394-B, de 26 de dezembro de 1984, com previsão para entrar em vigor no dia $1^{\circ}$ de julho de $1985 . .^{218}$

A norma revogou o imposto de transações, aprovado pelo Decreto-Lei n. 374-D/79, de 10 de setembro, a respectiva legislação complementar, e aboliu os seguintes impostos aplicados sobre o consumo: (i) imposto ferroviário, criado pelo Decreto-Lei n. 38245, de 5 de maio de 1951, (ii) imposto de turismo, regulamentado pelo Decreto-Lei n. 134/83, de 19 de março, (iii) a percentagem, cobrada a favor do Fundo de Socorro Social, nos termos do n. 3 do artigo $2^{\circ}$ do Decreto-Lei n. 47500, de 18 de janeiro de 1967, incidente sobre as despesas efetuadas em cassinos, salões públicos de dança e diversão, com ou sem variedades, bares e outros estabelecimentos congêneres, (iv) as hipóteses descritas no imposto do selo que conflitavam com o IVA, como por exemplo o incidente sobre as especialidades farmacêuticas.

\subsubsection{Medidas adotadas pela República Portuguesa para a solução dos} problemas enfrentados pela modificação do seu sistema tributário:

a) Para que não houvesse problemas em relação à neutralidade e prejuízo aos sujeitos passivos no momento da transição fiscal, os créditos porventura existentes do tributo IT, que foi revogado, seriam amplamente compensados com o IVA, a partir de sua vigência. $^{219}$

b) Definiu-se que a equipe responsável pelo desenvolvimento, implantação e acompanhamento dos resultados, sob a batuta de Alípio Dias, não seria modificada mesmo

\footnotetext{
217 SANTOS, António Carlos dos. Implicações do processo de integração de Portugal na Comunidade Europeia nas políticas fiscal e orçamental. In: SARAIVA FILHO, Oswaldo Othon de Pontes; VASQUES, Sérgio; GUIMARÃES, Vasco Branco (Org.). IVA para o Brasil: contributos para a reforma da tributação do consumo. Belo Horizonte: Fórum, 2007. p. 221-258.

218 DEVESA, Jaime. IVA: Código do Imposto sobre o Valor Acrescentado. Coimbra, Portugal: Almedina, 2003. Artigo 10, p. 22.

${ }^{219}$ Artigo $3^{\circ}$ do CIVA e Decreto-Lei n. 351/85 (DEVESA, Jaime. IVA: Código do Imposto sobre o Valor Acrescentado. Coimbra, Portugal: Almedina, 2003).
} 
se houvesse troca de governo; dessa forma, assegurou-se a continuidade e a qualidade do serviço, para além das posições políticas da República. ${ }^{220}$

c) A segurança jurídica foi reforçada, com o estabelecimento do prazo de um ano após a vigência do IVA para que houvesse qualquer autuação fiscal, salvo em caso de culpa grave apurada e autorização expressa do diretor geral das contribuições e impostos. Nesse período, a fiscalização deveria atuar de forma a orientar os contribuintes.

d) No período transitório conferido pelo tratado de adesão, excluiu-se da incidência um conjunto de bens considerados essenciais para o consumo humano, a fim de evitar uma passagem brusca ao sistema de base ampla do IVA.

e) Estabeleceu-se um regime especial para os pequenos contribuintes, em especial mediante a simplificação das regras de cumprimento das obrigações acessórias, no regime transitório.

f) Considerando a inexistência, no período, de maiores restrições relativas às alíquotas que poderiam ser adotadas pelos países, aplicou-se amplamente a progressividade delas, aliviando a carga para os gêneros alimentícios e prestação de serviços essenciais e majorando-as para os artigos de luxo, em atendimento ao disposto na Constituição portuguesa, que exige a aplicação da seletividade nesses casos. ${ }^{221}$

g) Houve o cuidado de manipular as alíquotas com o objetivo de assegurar que a receita do IVA fosse próxima à obtida com os impostos que seriam substituídos, de forma a não causar distúrbios financeiros ao país. A ampliação da base de incidência permitiu aliviar a pressão sobre as alíquotas.

h) Medidas administrativas também contribuíram para o sucesso da implementação do IVA em Portugal, podendo ser destacados o reforço no recrutamento de pessoal habilitado no novo imposto, as campanhas de informação dirigida aos contribuintes e particulares, familiarizando-os com as novas obrigações fiscais, e a reforma do sistema de cobrança, que lançou mão das tecnologias disponíveis no período para elaborar "um sistema mais ágil e confiável”. 222

\footnotetext{
${ }^{220}$ BASTO, José Guilherme Xavier de. Adopção do sistema comum europeu de Imposto sobre o Valor Acrescentado (IVA) em Portugal. In: SARAIVA FILHO, Oswaldo Othon de Pontes; VASQUES, Sérgio; GUIMARÃES, Vasco Branco (Org.). IVA para o Brasil: contributos para a reforma da tributação do consumo. Belo Horizonte: Fórum, 2007. p. 100.

${ }^{221}$ Artigo 107, n. 4, da Constituição da República Portuguesa.

${ }^{222}$ BASTO, José Guilherme Xavier de. Adopção do sistema comum europeu de Imposto sobre o Valor Acrescentado (IVA) em Portugal. In: SARAIVA FILHO, Oswaldo Othon de Pontes; VASQUES, Sérgio; GUIMARÃES, Vasco Branco (Org.). IVA para o Brasil: contributos para a reforma da tributação do consumo. Belo Horizonte: Fórum, 2007. p. 98.
} 
Dessa feita, a adoção do IVA em Portugal no ano de 1986 foi realizada sem sobressaltos e "isso deveu-se em grande parte, à preparação prévia que fora desenvolvida em devido tempo". 223

Em recente análise sobre a experiência de implementação do IVA na República Portuguesa, Basto afirmou que o imposto deu as provas de que é um excepcional instrumento fiscal porque "é um imposto altamente produtivo, tendencialmente neutro nos seus efeitos econômicos, geralmente bem tolerado pelos contribuintes e de administração acessível, o que o torna muito atraente, em especial no período de profunda crise fiscal". ${ }^{224}$

\subsubsection{República Federal da Alemanha}

A República Federal da Alemanha ${ }^{225}$ é fundadora da Comunidade Econômica Europeia e, como tal, participou de todas as fases de harmonização do IVA impostas pelas diretivas do Conselho, entretanto não sem enfrentar uma série de problemas decorrentes da constitucionalidade e também da transposição do tipo de modelo criado por um Estado unitário (França) para um Estado federal.

Conforme o prazo estabelecido pelas duas primeiras diretivas, a Alemanha introduziu o IVA em janeiro de $1968^{226}$ e revogou os impostos cumulativos em cascata que vigoravam em seu território. É curioso notar que a reforma do sistema tributário foi também promovida não somente para atendimento das exigências impostas pela CEE, mas em decorrência da declaração de inconstitucionalidade proferida pelo Tribunal Constitucional Federal alemão em relação ao imposto plurifásico cumulativo sobre as vendas, denominado Allphasen-Brutto-Umsatzteuer. ${ }^{227}$

A decisão foi fundamentada na ofensa aos princípios constitucionais de direito econômico, por violar o princípio de igualdade de concorrência ou da neutralidade dos

${ }^{223}$ BASTO, José Guilherme Xavier de. Adopção do sistema comum europeu de Imposto sobre o Valor Acrescentado (IVA) em Portugal. In: SARAIVA FILHO, Oswaldo Othon de Pontes; VASQUES, Sérgio; GUIMARÃES, Vasco Branco (Org.). IVA para o Brasil: contributos para a reforma da tributação do consumo. Belo Horizonte: Fórum, 2007. p. 99.

${ }^{224}$ BASTO, José Guilherme Xavier de. Adopção do sistema comum europeu de Imposto sobre o Valor Acrescentado (IVA) em Portugal. In: SARAIVA FILHO, Oswaldo Othon de Pontes; VASQUES, Sérgio; GUIMARÃES, Vasco Branco (Org.). IVA para o Brasil: contributos para a reforma da tributação do consumo. Belo Horizonte: Fórum, 2007. p. 122.

${ }^{225} \mathrm{Na}$ época da fundação da CEE vigorava a divisão da Alemanha e o acordo foi assinado pela Alemanha Ocidental (também denominada República Federal da Alemanha).

${ }^{226}$ Lei do IVA alemã, Umsatzsteuergesetz (UStG), de 29 de maio de 1967, revista em 1973 e posteriormente modificada em 1979, em razão das alterações inseridas pela Sexta Diretiva IVA do Conselho.

${ }^{227}$ YAMASHITA, Douglas. ICMS e IVA: princípios especiais: capacidade contributiva, não cumulatividade, destino e origem. São Paulo: IOB, 2000. p. 9-10. 
tributos. Para o Tribunal, as grandes empresas poderiam planejar a concentração de atividades em uma única pessoa jurídica, reduzindo o circuito econômico e, consequentemente, a tributação. A ofensa configurava-se em detrimento das empresas alemãs de menor porte que não teriam o poder de reduzir os preços por meio desse planejamento. $^{228}$

Klaus Tipke relata que a adoção do IVA (Mehrwertsteuer) implicou séria controvérsia sobre a sua constitucionalidade, em razão dos artigos da Lei Fundamental alemã citarem explicitamente o imposto sobre vendas (Umsatzteuer) em diversos artigos relacionados à competência e à repartição de receitas. Entretanto, em favorecimento ao processo de integração, "prevaleceu o ponto de vista da não necessidade de reforma constitucional, pois o Umsatzsteuer era uma designação genérica e aberta que poderia abranger o IVA".229

Ao analisar o projeto de reforma alemã, Michele Pisaturo afirmou que a proposta recebeu amplo apoio de diversos setores da sociedade tedesca porque propunha solução para os três principais problemas relacionados à tributação do consumo vivenciados na Alemanha: eliminação do efeito cumulativo que gerava a concentração vertical das empresas, eliminação dos problemas decorrentes do ressarcimento ao exportador do valor do imposto indireto sofrido nas aquisições vinculadas aos produtos exportados e também assegurava o princípio da livre concorrência, falseado em razão do efeito cumulativo em cascata. $^{230}$

O último aspecto relevante que envolve adoção do IVA está relacionado à adoção de mecanismos para a sua implementação em um Estado federal, que via de regra compartilha competências tributárias no seio da federação.

A federação tedesca encontrou uma solução para equilibrar o conflito de forças entre os poderes da República, considerando que, em um Estado federal, o poder estatal deve ser dividido materialmente entre a União e os Estados membros (Länder). Segundo Klaus Tipke, a fórmula encontrada foi a repartição de competências de uma maneira diferenciada e complexa, objetivando equilibrar dois princípios a priori antagônicos: de

\footnotetext{
${ }^{228}$ BVerfGE (coletânea oficial de decisões do Tribunal Constitucional Federal alemão) ns. 18, p. 1, 21, p. 12 e 33, p. 22 (YAMASHITA, Douglas. ICMS e IVA: princípios especiais: capacidade contributiva, não cumulatividade, destino e origem. São Paulo: IOB, 2000. p. 9-10).

${ }^{229}$ TIPKE, Klaus. Derecho tributario: ¿caos, conglomerado o sistema? Revista de la Facultad de Derecho de Granada, n 146, 1976, p. 6-17.

${ }^{230}$ PISATURO, Michele Mario. L'imposta sul valore aggiunto: prospettive in relazione al sistema tributario ed agli obblighi internazionali dello Stato italiano. Napoli: E. Jovene, 1967.
} 
um lado, o princípio da autonomia, que atribui competências separadas à União e aos Länder e, de outro, o "princípio federativo", que fundamenta as competências comuns. ${ }^{231}$

Assim, o capítulo do sistema financeiro da Lei Fundamental compreende dois universos que se fundem em um só núcleo: "o direito constitucional-financeiro estatal federal e o direito constitucional do orçamento". Ambos fundamentam e coordenam as competências tributárias: "a soberania legislativo-tributária, a soberania da arrecadação tributária e a soberania administrativo-tributária". ${ }^{232}$

Por conseguinte os tributos são repartidos segundo um sistema misto: os grandes impostos (como os que alcançam a renda e o consumo de bens e serviços) são reunidos em um sistema integrado de impostos conjuntos, agrupados com distribuição compartilhada. Os demais são atribuídos segundo um sistema de partição inteiramente de competência da União ou inteiramente dos Länder.

A autoridade legislativa pode ser reservada exclusivamente para a União, ou compartilhada com os Estados membros (concorrente), podendo os Länder legislar sempre que, e na extensão que, a União legisle sobre o tema, ou exclusiva dos Länder $^{233}$. Na Alemanha, os municípios não possuem autoridade legislativa, salvo em relação à definição das alíquotas do imposto imobiliário. ${ }^{234}$

A autoridade da receita tributária (a soberania da arrecadação) pode ser exclusiva da União, dos Länder ou compartilhada, como ocorre com o IVA. As quotas da União e dos Länder são fixadas através de lei federal, mediante aprovação do Conselho Federal. ${ }^{235}$

Os tributos são administrados (soberania administrativa) pelas autoridades financeiras federais ou pelas autoridades financeiras do Land, que pode ser também decorrente da delegação do Bund (denominada administração por delegação). Segundo Gerd Willi, com exceção dos impostos relacionados ao comércio exterior, "somente os Estados membros possuem administração fiscal, a quem cabe a fiscalização e arrecadação

231 "A soberania fiscal não implica somente a competência legislativa, mas envolve, ainda, a competência administrativa e a competência de dispor de receita." (ROTHMANN, Gerd Willi. Tributação do consumo: Reflexões sobre uma reforma tributária economicamente racional e politicamente viável. No prelo. $\mathrm{O}$ artigo será publicado na Revista da pós-graduação da Faculdade de Direito da Universidade Federal de Minas Gerais, no primeiro trimestre de 2015. Arquivo cedido pelos organizadores do projeto e mediante anuência do autor).

${ }^{232}$ TIPKE, Klaus. Direito tributário. Tradução de Luiz Dória Furquim. Porto Alegre: Sergio Antonio Fabris, 2008. v. 1, p 126-127. As competências ou soberanias encontram-se disciplinadas nos art. 105 a 108 da Constituição Alemã.

${ }^{233}$ GERMANY. Basic Law for the Federal Republic of Germany, on 23 May 1949. Berlin: German Bundestag, 2008. Artigos 71-72 e 105.

${ }^{234}$ TIPKE, Klaus. Direito tributário. Tradução de Luiz Dória Furquim. Porto Alegre: Sergio Antonio Fabris, 2008. v. 1, p. 145-153.

${ }^{235}$ GERMANY. Basic Law for the Federal Republic of Germany, on 23 May 1949. Berlin: German Bundestag, 2008. Artigo 106. 
dos impostos federais, estaduais e municipais, independentemente da repartição das respectivas receitas". ${ }^{236}$

Nesses termos, a Lei Fundamental alemã estabelece a competência comum da Federação (Bund) e dos Estados (Länder) em relação ao IVA, sendo que compete ao Bund a legislação (uniformidade legislativa) e a arrecadação é compartilhada entre o Bund e os Länder, entretanto, um percentual deve ser revertido aos municípios. ${ }^{237}$

Para assegurar o interesse dos Länder no quesito legislativo, para as questões não definidas nas diretivas do Conselho, que conferem o caráter harmonizado do IVA europeu, o Conselho Federal (Bundesrat) exerce um importante papel, conforme estabelece a Constituição da Alemanha. É por meio do Conselho Federal que os Estados participam da legislação e da administração da federação, bem como das questões concernentes à União Europeia. Esse Conselho é formado por membros dos governos dos Estados. ${ }^{238}$

Por fim, há ainda uma reversão de valores arrecadados para os Estados menos desenvolvidos do país, por meio de um mecanismo denominado sistema de compensação financeira interestadual (Länderfinanzausgleich).

Conclui-se que o federalismo de cooperação alemão determina a equalização das receitas tributárias para reduzir as desigualdades regionais e o IVA é distribuído mediante os seguintes mecanismos:

(i) As receitas do IVA são repartidas entre o Bund e os Länder, conforme lei federal (os municípios participam dessa distribuição, conforme determinar a lei dos Länder).

(ii) A parte da receita dos Länder é redistribuída entre eles, tomando-se como base o desenho constitucional territorial. ${ }^{239}$

(iii) Há uma equalização entre os Estados membros em favorecimento aos Estados menos desenvolvidos, calculado conforme lei federal.

(IV) Os Estados menos desenvolvidos recebem um valor suplementar do Bund, nos termos da lei federal.

236 ROTHMANN, Gerd Willi. Tributação do consumo: Reflexões sobre uma reforma tributária economicamente racional e politicamente viável. No prelo. O artigo será publicado na Revista da pósgraduação da Faculdade de Direito da Universidade Federal de Minas Gerais, no primeiro trimestre de 2015. Arquivo cedido pelos organizadores do projeto e mediante anuência do autor.

${ }^{237}$ TORRES, Ricardo Lobo. É possível a criação do IVA no Brasil? In: SARAIVA FILHO, Oswaldo Othon de Pontes; VASQUES, Sérgio; GUIMARÃES, Vasco Branco (Org.). IVA para o Brasil: contributos para a reforma da tributação do consumo. Belo Horizonte: Fórum, 2007. p. 19-36.

238 GERMANY. Basic Law for the Federal Republic of Germany, on 23 May 1949. Berlin: German Bundestag, 2008. Artigos 50-51.

239 GERMANY. Basic Law for the Federal Republic of Germany, on 23 May 1949. Berlin: German Bundestag, 2008. Artigo 107. 
A fórmula encontrada pela Alemanha foi capaz de introduzir o IVA no poder central sem descurar da importância desse recurso para os demais entes, preservando o federalismo, protegido por cláusula pétrea, nos termos do artigo 79 da Lei Fundamental alemã. 


\section{CAPÍTULO 3 - PROJETO DE INTEGRAÇÃO REGIONAL LATINO- AMERICANO E O DESAFIO DE ERIGIR UM MERCADO COMUM NO ÂMBITO DO MERCOSUL}

\subsection{A consagração do mercado comum como princípio constitutivo}

O Mercado Comum do Sul (MERCOSUL) é um projeto de integração iniciado pela assinatura do Tratado de Assunção ${ }^{240}$ e tem como membros fundadores as Repúblicas Argentina, Federativa do Brasil, do Paraguai, e Oriental do Uruguai.

O acordo prevê a adesão de outros países da Associação Latino-Americana de Integração (ALADI), mediante aprovação unânime dos Estados membros, tendo sido a República Bolivariana da Venezuela o primeiro país a aderir ao bloco (2012) ${ }^{241}$. O Estado Plurinacional da Bolívia encontra-se em fase de adesão. ${ }^{242}$

Chile, Colômbia, Equador, Guiana, Suriname e Peru são Estados $\operatorname{associados}^{243}$ que cumpriram os três requisitos necessários para ostentar essa condição: firmaram acordos de livre comércio com o bloco, acolheram o Protocolo de Ushuaia ${ }^{244}$, que estabelece o compromisso democrático, e pertencem à ALADI. Os países associados ao Mercado Comum do Sul podem participar das reuniões institucionais do bloco, sem direito a voto. $\mathrm{O}$ tratado também dispôs sobre a possibilidade de um integrante desvincular-se das obrigações acordadas, mediante denúncia formal. ${ }^{245}$

\footnotetext{
${ }^{240}$ MERCOSUL. Tratado de Assunção. Tratado para a constituição de um mercado comum entre a República Argentina, a República Federativa do Brasil, a República do Paraguai e a República Oriental do Uruguai, de 26.03.1991. Disponível em: 〈www.mercosul.gov.br〉. Acesso em: 20 out. 2014.

${ }^{241}$ A Venezuela é membro pleno desde 12 de agosto de 2012, quando entrou em vigor o Protocolo de Adesão da República Bolivariana da Venezuela ao MERCOSUL. O processo foi polêmico e somente se tornou possível com a suspensão temporária do Paraguai, decorrente da suposta quebra do compromisso democrático ocorrida pelo afastamento do presidente do país Fernando Lugo. O Paraguai não aprovava o ingresso da Venezuela.

${ }^{242}$ MERCOSUL. Protocolo de adesão do Estado Plurinacional da Bolívia ao MERCOSUL. Brasília, 07.12.2012. Disponível em: <www.mercosul.gov.br〉. Acesso em: 20 out. 2014.

${ }^{243}$ Conforme Decisões do Conselho Mercado Comum: Peru (Decisão n. 39/2003), Equador (Decisão n. 43/2004), Colômbia (Decisão n. 44/2004), Guiana (Decisão n. 12/2013) e Suriname (Decisão n. 13/2013). A forma de participação nas reuniões e as condições para a assinatura de acordos com o MERCOSUL estão disciplinadas nas Decisões ns. 18/2004, 28/2004 e 11/2003. O Chile formalizou sua associação ao MERCOSUL em 25.06.1996, durante a X Reunião da Cúpula do MERCOSUL, em San Luis, na Argentina, pela assinatura do Acordo de Complementação Econômica MERCOSUL-Chile (ACE n. 35; CMC n. 3/96).

${ }^{244}$ MERCOSUL. Protocolo de Ushuaia I. Sobre o Compromisso Democrático no MERCOSUL, Bolívia e Chile. Ushuaia, 24.07.1998. Protocolo de Ushuaia II. Montevidéu, 20.12.2011. No Brasil, o Protocolo de Ushuaia foi aprovado pelo Decreto Legislativo n. 452, de 14.11.2001, e promulgado pelo Decreto n. 4. 210, de 24.04.2002.

${ }^{245}$ Artigo 21 do Tratado de Assunção.
} 
O MERCOSUL erigiu-se como uma nova tentativa de esforço de integração regional gestada pelo Tratado de Montevidéu de $1980^{246}$ e os fundamentos de sua constituição espelham, em grande parte, os anseios do projeto europeu: a busca pela ampliação dos mercados nacionais como pressuposto para acelerar os processos de desenvolvimento econômico e social, e a coordenação regional de políticas macroeconômicas para lograr uma adequada inserção internacional, cada vez mais difícil de ser alcançada de forma isolada pelos países, principalmente em razão do fenômeno da consolidação de grandes espaços econômicos.

O tratado fundador buscou estabelecer os propósitos e princípios da integração, consagrando, no artigo inaugural, a decisão de constituir um mercado comum e reconhecer as quatro grandes liberdades entre os seus integrantes. Embora o acordo não tenha estabelecido um cronograma específico para o cumprimento de etapas a serem superadas, firmou-se o compromisso que o Mercado Comum do Sul deveria estar estabelecido em 31 de dezembro de 1994.

O Tratado de Assunção estabeleceu um período de transição ${ }^{247}$ para alcançar a livre circulação de mercadorias, no qual deveriam vigorar um regime de certificação de origem dos bens ${ }^{248}$, um sistema precário de solução de controvérsias ${ }^{249}$ e cláusulas de salvaguarda comerciais $^{250}$, delineados nos Anexos II, III e IV.

Durante o período transitório, as medidas assentaram-se em um programa de liberação comercial de reduções tarifárias e não tarifárias, a coordenação de políticas macroeconômicas, a adoção de acordos setoriais, com o fim de aperfeiçoar a utilização e a mobilidade dos fatores de produção, e a adoção da tarifa externa comum em relação a terceiros países.

Para atingir o estágio de um mercado comum, o acordo internacional firmado estabeleceu metas ambiciosas a serem cumpridas e, considerando a estrutura institucional

246 MENEZES, Wagner. Mercado Comum do Sul (MERCOSUL). In: MERCADANTE, Araminta de Azevedo; CELLI JUNIOR, Umberto; ARAÚJO, Leandro Rocha de (Orgs.). Blocos econômicos e integração na América Latina, África e Ásia. Curitiba: Juruá, 2006. v. 1, p. 140.

247 O período de transição vigorou entre a data da entrada em vigor do tratado até 31.12.1994, conforme o artigo $3^{\circ}$ do Tratado de Assunção.

${ }^{248}$ Para a aplicação das regras do MERCOSUL as mercadorias devem ser certificadas por meiodo regime de origem, que exige a comprovação da sua fabricação no território do Estado membro, mediante a utilização de pelo menos $60 \%$ de conteúdo oriundo do MERCOSUL ou que tenha sofrido uma alteração substancial no território do MERCOSUL, e desde que contenha uma classificação NCM diferente dos insumos utilizados. Essas regras são transitórias e está prevista a sua vigência até o dia 31.12.2016, nos termos da Decisão CMC n. 44/2010.

${ }^{249}$ O Anexo III do Tratado trouxe um mecanismo preliminar de solução de controvérsias que vigorou até a entrada em vigor do Protocolo de Brasília, posteriormente reformulado pelo Protocolo de Olivos.

${ }^{250}$ O Anexo IV previu a aplicação de cláusulas de salvaguarda para casos excepcionais, em relação a importações de produtos que se beneficiassem do programa de liberação comercial. 
inicialmente proposta e o modelo intergovernamental adotado, pode-se afirmar que os resultados iniciais não foram frustrantes.

O primeiro compromisso estabelecia a livre circulação de mercadorias entre os Estados membros e a elaboração de uma tarifa externa comum a ser aplicada no comércio com terceiros países. Nesse quesito, houve avanços consideráveis: a partir de 01.01.1995, os quatro Estados membros do MERCOSUL adotaram a Tarifa Externa Comum (TEC) ${ }^{251}$, com base na Nomenclatura Comum do MERCOSUL (NCM), conforme previsto no Tratado de Assunção, e foram eliminados os direitos aduaneiros para a circulação de mercadorias entre os países integrantes do acordo.

A constituição da união aduaneira foi um passo importante em direção à instituição do mercado comum, entretanto o compromisso de eliminar as listas de mercadorias excetuadas do regime, prevista no Anexo I do tratado, não foi cumprido até a presente data $^{252}$. O MERCOSUL não conseguiu concretizar a união aduaneira de forma completa, mesmo após as alterações promovidas pelos Protocolos de Brasília (1991) ${ }^{253}$, Ouro Preto $(1994)^{254}$ e Olivos (2002). ${ }^{255}$

O compromisso de harmonização das legislações em áreas pertinentes, para afastar as barreiras de todas as naturezas e assegurar as liberdades no âmbito do MERCOSUL avançou em alguns domínios ${ }^{256}$, entretanto, não foi possível prosseguir na aproximação das legislações dos Estados membros em relação aos tributos indiretos, para evitar distorções e desequilíbrios de concorrência no mercado comum que se almeja instituir, apesar dos esforços empreendidos.

Nessa perspectiva, à medida que avançam os processos para a implementação do mercado comum, potencializam-se os impactos oriundos das diferenças nas estruturas

\footnotetext{
${ }^{251}$ A tarifa externa comum mantém uma lista de exceções, aprovadas pelo Conselho do Mercado Comum, dentre as quais se destacam as seguintes Decisões CMC ns. 68/2000, 31/2003, 38/2005, 59/2007, 28/2009 e 58/2010. Disponível em: 〈www.mercosur.int〉. Acesso em: 15 ago. 2014.

${ }^{252}$ De acordo com o programa de liberação comercial estabelecido no Anexo I, os Estados membros deveriam eliminar até 31.12.1994 os gravames e demais restrições aplicadas ao seu comércio recíproco. No que se refere às listas de exceções apresentadas pelo Paraguai e Uruguai, o prazo deveria finalizar no dia 31.12.1995.

${ }^{253}$ O Protocolo de Brasília foi revogado com a entrada em vigor do Protocolo de Olivos.

${ }^{254}$ MERCOSUL. Protocolo de Ouro Preto. Protocolo adicional ao Tratado de Assunção sobre a estrutura institucional do MERCOSUL. Disponível em: <www.mercosul.gov.br>. Acesso em: 15 ago. 2014. No Brasil, esse Protocolo foi aprovado pelo Decreto Legislativo n. 188, 16.12.1995, e promulgado pelo Decreto n. 1.901, de 09.05.1996.

${ }^{255}$ MERCOSUL. Protocolo de Olivos. Para a solução de controvérsias no Brasil. Aprovado pelo Decreto Legislativo n. 712, de 15.10.2003, e promulgado pelo Decreto n. 4.982, de 09.02.2004.

${ }^{256}$ No tocante à livre circulação de pessoas, por exemplo, foram aprovados acordos que estabelecem as condições para residência e trabalho para os nacionais dos Estados membros (MERCOSUL. Acuerdo sobre Residencia para los Nacionales de los Estados Partes del MERCOSUR, de 06/12/2002 e acuerdo sobre Residencia para los Nacionales de los Estados Partes del MERCOSUR, Bolivia y Chile, de 06/12/2002).
} 
tributárias dos Estados membros, razão pela qual a harmonização das legislações é condição inarredável para a sua concretização.

Como não é possível prosseguir sem que se inicie a harmonização pelos tributos que impactam diretamente na livre circulação de bens e serviços, ou seja, os tributos incidentes sobre o consumo, faz-se mister analisar se a estrutura institucional de cariz intergovernamental, os atos decorrentes do processo de decisão emanados dessas instituições e a forma de incorporação do direito mercosulino nos ordenamentos jurídicos dos países integrantes são capazes de promover essa necessária harmonização.

\subsection{Estrutura institucional e a incorporação do direito do MERCOSUL nos ordenamentos jurídicos dos Estados partes}

O Tratado de Assunção estabeleceu o compromisso dos Estados convocarem uma reunião extraordinária antes do término do período transitório, para determinar a estrutura institucional definitiva do mercado comum, as atribuições específicas e o sistema de tomada de decisões de cada órgão, o que de fato ocorreu com a assinatura do Protocolo de Ouro Preto, em 17 de dezembro de $1994 .^{257}$

A estrutura institucional vigente, após as alterações implementadas ao longo dos vinte e três anos de existência do bloco, é composta pelas seguintes instituições:

1. Conselho do Mercado Comum (CMC): é o órgão responsável pela condução política da integração e toma decisões que buscam assegurar o cumprimento dos objetivos e prazos estabelecidos para a constituição definitiva do mercado comum. Para dar cumprimento às suas competências, deve formular políticas no sentido de conformar o mercado comum, velar pelo cumprimento dos tratados e exercer a titularidade jurídica do bloco $^{258}$, podendo assinar acordos com terceiros países e organizações internacionais. O CMC manifesta-se mediante decisões, instrumento que obrigam os Estados membros.

Dentro de suas prerrogativas, o CMC criou o foro de assuntos tributários ${ }^{259}$, com o objetivo de assegurar as condições adequadas para a consolidação e o aperfeiçoamento da união aduaneira, promover maior conhecimento recíproco dos sistemas tributários dos

\footnotetext{
${ }^{257}$ No tocante ao regime de solução de controvérsias, o Protocolo de Brasília, que deveria permanecer em vigor apenas no período transitório, acabou prevalecendo, salvo pequenas alterações produzidas pelo Protocolo de Ouro Preto, até a publicação do Protocolo de Olivos.

${ }^{258}$ O MERCOSUL tem personalidade jurídica de direito internacional, conforme estabelece o artigo 34 do Tratado de Assunção.

259 MERCOSUL/CMC/Decreto n. 31/2008. Disponível em: <www.mercosul.org.br>. Acesso em: 20.10.2014.
} 
Estados, constituir um espaço para a troca de informações sobre questões fiscais e apresentar sugestões de ação nesse domínio.

2. Grupo Mercado Comum (GMC): é o órgão executivo do bloco, responsável por velar pelo cumprimento dos tratados, propor projetos de decisão ao CMC, fixar programas de trabalho para fazer o bloco avançar, organizar as reuniões do CMC e preparar os relatórios e estudos que ele lhe solicitar. Pronuncia-se mediante resoluções, que são obrigatórias para os Estados membros.

3. Comissão de Comércio do MERCOSUL (CCM): é o órgão encarregado de assistir o GMC, velar pela aplicação dos instrumentos de política comercial comum intrabloco, com terceiros países e organismos internacionais. Compete a ele acompanhar a aplicação e o cumprimento da tarifa externa comum (TEC). Manifesta-se por diretrizes, que também são obrigatórias.

4. Foro Consultivo Econômico-Social (FCES): é o órgão de representação dos setores econômicos e sociais dos países mercosulinos, tem função consultiva e manifestase mediante recomendações ao GMC.

5. Secretaria Administrativa do MERCOSUL (SM): é o órgão de apoio operacional e presta serviços aos demais órgãos do MERCOSUL.

6. Parlamento do MERCOSUL ${ }^{260}$ : tem como missão aprofundar o processo de integração e constitui-se em órgão de representação dos cidadãos dos países integrantes, independente, autônomo e unicameral. A sua principal missão é acelerar os procedimentos de "internamento" das normas emanadas das instituições do MERCOSUL nos Estados membros. O Parlamento elabora pareceres sobre todos os projetos de normas do MERCOSUL que requeiram aprovação legislativa interna e, por essa razão, os projetos das instituições que pretendem editar uma norma deverão ser encaminhados pelo órgão decisório antes de sua aprovação. Após a aprovação, a norma deverá ser enviada pelo Poder Executivo nacional ao seu respectivo parlamento, dentro do prazo de quarenta e cinco dias. Se o projeto não for aprovado nos termos do parecer do Parlamento do MERCOSUL, seguirá o trâmite ordinário de incorporação. No momento da criação do Parlamento do MERCOSUL, firmou-se o compromisso dos parlamentos nacionais adotarem as medidas necessárias para a instrumentalização ou criação de um procedimento preferencial para a consideração das normas do MERCOSUL que tenham sido adotadas de

\footnotetext{
260 MERCOSUL. Protocolo Constitutivo do Parlamento do MERCOSUL, Montevidéu, 09.12.2005. O protocolo foi aprovado no Brasil pelo Decreto Legislativo n. 408, de 12.09.2006, e promulgado pelo Decreto n. 6.105, de 30.04.2007. Disponível em: <www.mercosul.org.br〉. Acesso em: 20.10.2014.
} 
acordo com os termos do parecer, cujo prazo máximo não poderá exceder cento e oitenta dias, contados do ingresso da norma no respectivo parlamento nacional (procedimento preferencial). Outras duas tarefas relevantes atribuída ao Parlamento que são vitais para o desenrolar da integração são o direito de propor projetos de normas ao CMC e elaborar estudos e anteprojetos de normas nacionais, orientados à harmonização das legislações internas dos Estados membros, os quais serão comunicados aos parlamentos nacionais, com vistas à sua eventual consideração.

O Parlamento decide por maioria simples, absoluta, especial ou qualificada, conforme regras estabelecidas em seu regimento.

7. Tribunal Arbitral e Tribunal Permanente do MERCOSUL: as controvérsias decorrentes da interpretação, aplicação ou não cumprimento dos tratados e das normas institucionais serão submetidas aos procedimentos estabelecidos no Protocolo de Olivos. O mecanismo de solução de controvérsias inicia-se com as negociações diretas, deságua na intervenção do GMC e, na hipótese de permanência do conflito, instaura-se o procedimento arbitral, mediante composição do Tribunal Arbitral Ad Hoc, podendo ser ainda submetida ao procedimento de revisão, realizada pelo Tribunal Permanente de Revisão (TPR), estabelecido em Assunção. O TPR confirma, modifica ou revoga a fundamentação jurídica e as decisões do Tribunal Arbitral Ad Hoc e o seu laudo é definitivo, prevalecendo sobre o laudo antecedente, obrigatório e com força de coisa julgada.

A estrutura normativa é ainda composta pelo Tribunal Administrativo-Laboral do MERCOSUL (TAL) ${ }^{261}$ e o Centro MERCOSUL de Promoção do Estado de Direito $(\mathrm{CMPED})^{262}$, com atribuições bem específicas e competências disciplinadas nas normas criadoras emanadas do GMC e da CMC.

Como pode ser observado, o MERCOSUL dispõe de uma estrutura institucional robusta, e possui competências para fazer avançar o projeto de integração, embora as decisões dos órgãos executivos sejam tomadas por consenso e, ainda que de caráter obrigatório, dependam de incorporação aos ordenamentos jurídicos nacionais, mediante os procedimentos previstos pela legislação de cada país.

O procedimento para assegurar a vigência simultânea em todos os países do bloco encontra-se estabelecido no artigo 40 do Protocolo de Ouro Preto e pressupõe os seguintes

\footnotetext{
${ }^{261}$ Criado pela Resolução n. 54/2003 do GMC, é a única instância jurisdicional para resolver reclamações de índole administrativa-trabalhista das pessoas que trabalham nos órgãos do MERCOSUL.

${ }^{262}$ Criado pela Decisão n. 24/2004 do CMC, tem a finalidade de analisar e reforçar o desenvolvimento dos Estados, a governabilidade, a liberdade democrática. Funciona atualmente na sede do TPR, em Assunção.
} 
ritos: (i) aprovada a norma, os Estados adotam as medidas necessárias para a sua incorporação ao ordenamento jurídico nacional e comunicam a conclusão à Secretaria do MERCOSUL; (ii) após a comunicação de todos os Estados membros, a Secretaria administrativa do MERCOSUL dá ciência da conclusão do processo aos Estados membros; (iii) as normas entram em vigor simultaneamente nos Estados membros, trinta dias após a data de comunicação efetuada pela Secretaria do MERCOSUL.

A doutrina dos países integrantes aponta a necessidade de revisão dos tratados para dotar de maior eficiência e eficácia os órgãos, bem como uma modificação na forma estabelecida para a tomada de decisões e a metodologia de incorporação normativa pelos Estados membros. ${ }^{263}$

De fato, o processo de constituição do mercado comum no âmbito do MERCOSUL seria mais célere se todos os Estados membros realizassem as alterações constitucionais pertinentes para assegurar a supremacia do direito da integração sobre o direito nacional, a aplicação direta de suas normas e o fortalecimento do tribunal de justiça, também supranacional, para assegurar a uniformidade da interpretação e da aplicação dos tratados e das decisões dos órgãos institucionais.

A ausência de um poder supranacional ${ }^{264}$ é o maior desafio a ser cumprido em relação à harmonização das legislações tributárias que incidem sobre o consumo nos Estados membros e, como tal, um relevante obstáculo a ser transposto para a concretização do mercado comum.

\subsection{A harmonização dos impostos sobre o consumo de bens e serviços}

O Tratado de Constituição do MERCOSUL, além do compromisso de harmonizar suas legislações, contém um único artigo que faz referência direta aos tributos vigentes nos Estados membros, a saber:

Artigo $7^{\circ}$ - Em matéria de impostos, taxas e outros gravames internos, os produtos originários do território de um Estado-parte gozarão, nos outros Estados-partes, do mesmo tratamento que se aplique ao produto nacional.

\footnotetext{
${ }^{263}$ DELUCA, Santiago. El Mercosul necessita su Maastricht. Revista Pensar en Derecho, Buenos Aires, Editorial Universitaria de Buenos Aires, año 1, n. 1, p. 247-265, dic. 2012.

264 "A ausência de estrutura institucional supranacional representa ao mesmo tempo escolha e risco para o futuro desse espaço economicamente integrado, tal como ora se apresenta, sobretudo a partir da consolidação da união aduaneira. Aceita a integração como ideia, tem esta de ser viabilizada como proposta e aí começam as distorções do momento atual: nem o modelo institucional e constitucional, nem o contexto político ou a imaturidade do debate presente tornam viável, ou ao menos se poderia dizer sejam favoráveis à implementação da integração." (CASELA, Paulo Borba. Mercosul: exigências e perspectivas: integração e consolidação de espaço econômico. São Paulo: LTR, 2006, p. 36).
} 
A norma estabelece o princípio universal da não discriminação, presente em todos os acordos internacionais que objetivam liberar a circulação de mercadorias, não se configurando, portanto, novidade em relação ao processo de integração no âmbito do MERCOSUL. O artigo $7^{\circ}$ do Tratado apenas assegura a isonomia tributária para as mercadorias que circulam no comércio intrabloco, ao estabelecer o compromisso de aplicação, aos produtos importados, da mesma carga tributária exigida para os produtos nacionais.

A necessidade de aproximar as legislações tributárias que alcançam o consumo de bens e serviços nunca deixou de ser uma preocupação das instituições do MERCOSUL, embora não tenham avançado até o momento, em razão do modelo intergovernamental e da ausência do poder supranacional.

É possível superar esse passo, no sentido de aprofundar a integração no modelo intergovernamental, entretanto dependerá da vontade política dos Estados em aprovar tipos impositivos adequados à harmonização, para que o processo seja conduzido, a partir dessa conformação, pelas instituições do bloco.

A primeira tentativa de criação de um projeto de harmonização da tributação indireta foi elaborada pela Comissão de Aspectos Tributários (Subgrupo de trabalho 10 de políticas macroeconômicas), publicado no ano de 1995.

O estudo, denominado "Informe sobre a harmonização dos impostos gerais do consumo nos processos de integração econômica"265 procurou evidenciar as diferenças existentes entre os sistemas tributários dos países do bloco, seus efeitos negativos na concorrência e as dificuldades de integração em decorrência dessas divergências. $\mathrm{O}$ informe evidenciou que, com exceção do Brasil, os demais países já adotavam tributos muito similares aos impostos que incidem sobre o valor agregado, passíveis de harmonização. No caso da República Federativa brasileira, o complexo sistema tributário

\footnotetext{
${ }^{265}$ O estudo baseou-se nas seguintes premissas: “(i) Nos processos de integração econômica caracterizados pela fusão dos mercados nacionais, mediante a eliminação das barreiras aduaneiras e das restrições não tarifárias, com o propósito de assegurar a livre circulação de bens, serviços e fatores produtivos, a harmonização dos impostos ao consumo resulta necessária possibilitar essa livre circulação em relação a bens e serviços, associando-se à formação de um mercado ampliado, baseado na livre concorrência dos produtores dos países associados. (ii) Dado que tanto os impostos gerais ao consumo como os seletivos ou específicos se desenham de forma que se transportem de forma direta aos preços, com o fim de assinalar a carga tributária que suportam os consumidores finais, resulta evidente que as diferenças que se registre na modalidade técnica adotada por aqueles países para estruturá-los, assim como os critérios e níveis de imposição aplicados, podem distorcer as condições de concorrência que devem imperar no mercado ampliado, ao afetar de forma direta a formação de custos e preços dos bens suscetíveis de intercâmbio." (AMARAL, Antonio Carlos Rodrigues. Tributação no Mercosul. In: MARTINS, Ives Gandra da Silva. Tributação no Mercosul. São Paulo: Revista dos Tribunais; Centro de Extensão Universitária, 2002. p. 482483).
} 
seria um desafio a transpor, principalmente em decorrência das competências tributárias atribuídas aos Estados e Municípios, o que exigiria uma conformação interna, antes de avançar o processo de harmonização da legislação do consumo. Entretanto, o estudo não resultou em nenhuma ação concreta das instituições, justamente por esbarrar em questões tão ligadas à soberania e exigirem reformas estruturais.

A segunda fase preparatória para um projeto de harmonização das legislações tributárias dos Estados membros iniciou-se em 2003 e ainda não foi concluída.

O Conselho do MERCOSUL, ao estabelecer o calendário de atividades do biênio 2004/2006, decidiu ${ }^{266}$ promover reuniões de especialistas em matéria tributária para analisar os tributos indiretos vigentes nos Estados que incidam nos fluxos comerciais. Após as palestras que ocorreram no primeiro semestre de 2004, concluiu-se que seria necessário desenvolver estudos mais aprofundados, em decorrência das divergências apuradas, em especial a constatação da presença de impostos em cascata que reduzem a competitividade da economia, ao encarecerem as exportações, já que não podem descarregar os impostos acumulados nas etapas anteriores. Esse tipo de imposto gera um problema no momento da sua devolução quando a mercadoria é exportada, devido às dificuldades em determinar com precisão a incidência do imposto sobre a mercadoria exportada. Estabeleceu-se a necessidade de identificar os impostos diretos e indiretos vigentes nos diversos níveis de governo dos Estados, com o fim de determinar assimetrias tributárias vigentes e comparar a carga tributária nos Estados partes do MERCOSUL.

O projeto, que ficou a cargo da Comissão de Comércio do MERCOSUL, recebeu o apoio financeiro do Banco Interamericano de Desenvolvimento (BID) para a contratação de uma consultoria especializada em direito tributário, estabelecida em qualquer país integrante do MERCOSUL para elaborar um relatório que contivesse os seguintes componentes:

(i) identificação dos procedimentos, regulamentos ou normas administrativas que possam gerar barreiras ao comércio, nos países integrantes do MERCOSUL;

(ii) apresentação de um estudo comparado das legislações dos impostos diretos e indiretos que afetam o comércio intrazona, identificando os impostos cumulativos e em cascata que incidam nas exportações e que possam deteriorar a competitividade das exportações;

\footnotetext{
${ }^{266}$ MERCOSUL/CMC/Dec. n. 26/2003. Programa de Trabalho do MERCOSUL 2004-2006.
} 
(iii) identificação dos impostos e mecanismos de aplicação que discriminem as importações procedentes de outros Estados membros;

(iv) estimativa do grau de acumulação da carga tributária, como consequência da falta de neutralidade da tributação interna; do impacto desses impostos sobre os fluxos de comércio do país afetado; da participação dos impostos que geram distorções ao comércio intrazona sobre o total de ingressos fiscais e de sua evolução nos últimos cinco anos;

(v) propostas para a harmonização da tributação indireta no âmbito do MERCOSUL.

O Informe, coordenado pelo uruguaio Félix Abadi Pilosof, foi disponibilizado aos países integrantes no final de 2009, para que eles apresentassem os seus comentários e solicitações de alteração ou complementação. Até o presente momento, apenas o Paraguai $^{267}$ e o Brasil ${ }^{268}$ apresentaram as suas considerações.

O moroso processo intergovernamental impactará negativamente a atuação das instituições no sentido de promover a almejada harmonização, notadamente porque os países integrantes já fizeram, após a conclusão do estudo finalizado em 2009, significativas reformas nos seus sistemas tributários.

${ }^{267}$ PARAGUAI. Documento Informativo n. 35/2009. Apresentado na Reunião Ordinária da Comissão de Comércio do MERCOSUL. 19 a 22 de outubro de 2009. Montevidéu, Uruguai.

${ }^{268}$ Anexo XII (Reservado) MERCOSUL/CXV CCM/DI n. 26/2010. Análise do informe final do estudo de identificação de impostos diretos e indiretos apresentado pelo Brasil. 


\section{CAPÍTULO 4 - 0 SISTEMA TRIBUTÁRIO DOS NOSSOS PARCEIROS: REPARTIÇÃO DE COMPETÊNCIAS E ESPÉCIES TRIBUTÁRIAS QUE ALCANÇAM O CONSUMO}

\subsection{Sistema tributário da República Federativa da Argentina}

A República Argentina adota a forma federal ${ }^{269}$, erigida pela vontade das províncias que a compõem e inspirada em diversos pactos preexistentes que já dispunham sobre o objetivo de constituir a união nacional. ${ }^{270}$

A vetusta Constitución de la Nación Argentina ${ }^{271}$ não cuidou de estabelecer um capítulo dedicado ao sistema tributário e não especificou as espécies tributárias existentes para o exercício do poder de tributar, missão que ficou a cargo da doutrina: definir que a base do sistema tributário argentino é composta por três espécies tributárias: os impostos, as taxas e as contribuições de melhoria. ${ }^{272}$

A Nação, as províncias e os municípios são titulares de poderes tributários, possuem competência para instituir e cobrar tributos ${ }^{273}$, norteados pelos princípios da igualdade, do respeito à capacidade contributiva e da progressividade. ${ }^{274}$

269 ARGENTINA. Constitución de la Nación Argentina. Ley n. 24.430, "artículo 1: La Nación Argentina adopta para su gobierno la forma representativa republicana federal, según la establece la presente Constitución."

${ }^{270}$ A preexistência histórica das províncias originárias é que deu origem à Federação e se conservaram todos os poderes originários não delegados taxativamente ao governo federal na Constitución Nacional. Sobre os pactos antecedentes, sugere-se a leitura dos seguintes artigos: URRESTI, Esteban Juan; CARDOZO, Horacio Félix. Comentários sobre la instauración del impuesto al valor agregado en un Estado Federal. In: BALTHAZAR, Ubaldo Cesar (Org.). Reforma tributária e Mercosul: a instituição do IVA no direito tributário brasileiro. Belo Horizonte: Del Rey, 1998. p. 145-163; CETRÁNGOLO, Oscar; JIMÉNEZ, Juan Pablo. Las relaciones entre niveles de gobierno en Argentina. Revista de la CEPAL, Buenos Aires, CEPAL, n. 84, p 117-134, dic. 2004.

${ }^{271}$ Sancionada em 1853 e reformada nos anos de 1860, 1898, 1957 e 1994.

${ }^{272}$ ALTAMIRANO, Alejandro C. Estrutura basica del Impuesto al Valor Agregado (IVA) en la Republica Argentina. In: BALTHAZAR, Ubaldo Cesar (Org.). Reforma tributária e Mercosul: a instituição do IVA no direito tributário brasileiro. Belo Horizonte: Del Rey, 1998. p. 72. O autor esclarece: “Os impostos são prestações patrimoniais geralmente exigíveis em dinheiro, sem contraprestação específica, usados na satisfação de necessidades coletivas. As taxas, por sua vez, são prestações em dinheiro devidas em virtude da prestação de um serviço público aproveitado pelo destinatário. As contribuições de melhoria constituemse em prestações pecuniárias devidas por quem experimentou um acréscimo no valor de seu bem em razão de uma obra pública."

${ }^{273}$ Há críticas em relação aos conflitos gerados em razão da faculdade tributária atribuída aos municípios. A doutrina e a jurisprudência têm compreendido que os limites ao exercício da competência dos municípios encontram-se estabelecidos nas Constituições e leis das províncias, nos termos do artigo $5^{\circ}$ da Constituição da República Argentina.

${ }^{274}$ Conforme dispõem os artigos $4^{\circ}$ e $16^{\circ}$ da Constituição da República Argentina. Nesse sentido: ZARINI, Helio Juan. Análisis de la Constitución nacional: comentario exegético, origen, reformas, concordancias y antecedentes. 3. ed., ampl. y actual. Buenos Aires: Astrea, 1991. p. 34 e 95. 
O texto constitucional dispõe que os poderes tributários das províncias são amplos e compete a elas coordenar a potestade dos municípios. O poder de tributar outorgado à Nação é, em tese, limitado, modelo que a realidade tributária vigente na Federação Argentina e a doutrina do país cuidam de desmentir. ${ }^{275}$

São atribuições do Congresso da Nação ${ }^{276}$ (bicameral, composto pela Câmara dos Deputados e pelo Senado) legislar em matéria aduaneira, impor tributos indiretos com faculdade concorrente com as províncias, impor exações diretas, por tempo determinado, proporcionalmente iguais em todo o território da Nação, quando a defesa, segurança comum e bem-estar geral do Estado o exijam, estabelecer a forma de repartição das receitas arrecadadas (com exceção daquelas que contenham destinação específica) e regular o comércio com as nações estrangeiras e as províncias entre si.

Conforme se extrai da norma constitucional, a atribuição de competências tributárias na estrutura federal de governo na Argentina contém as seguintes premissas:

(i) Os impostos diretos pertencem às províncias, porque não houve delegação de competência para a Nação. A exceção admitida constitucionalmente para a exigência pela Nação submete essa exação a prazo determinado, uniformidade nacional e destinação específica à defesa, à segurança comum e ao bem-estar geral do país;

(ii) Os impostos indiretos, que alcançam o consumo de bens e serviços, são de competência concorrente entre o Estado Federal e as províncias.

(iii) Os direitos aduaneiros são de competência exclusiva da Nação.

(iv) Os tributos municipais serão autorizados pelas leis das províncias.

(v) É obrigatória a repartição da receita tributária entre a Nação e as províncias e entre as províncias e os municípios.

No tocante ao tema relevante para esta tese, observa-se que a competência concorrente da imposição indireta ocasiona uma sobreposição de impostos sobre o consumo, sem que haja qualquer delimitação constitucional a respeito do aspecto material da norma que criará a exação.

\footnotetext{
${ }^{275}$ URRESTI, Esteban Juan; CARDOZO, Horacio Félix, Comentários sobre la instauración del impuesto al valor agregado en un Estado Federal, in Reforma tributária e Mercosul: a instituição do IVA no direito tributário brasileiro, cit., p. 147; CETRÁNGOLO, Oscar; JIMÉNEZ, Juan Pablo, Las relaciones entre niveles de gobierno en Argentina, cit., p. 117-134, 2004; BIDART CAMPOS, Germán José. El federalismo argentino desde 1930 hasta la actualidade. In: CARMAGNANI, Marcello (Coord.). Federalismos latinoamericanos: México, Brasil, Argentina. México, DF: El Colegio de México; Fondo de Cultura Económica, 1993. (Serie Estudios. Fideicomiso Historia de las Américas); PORTO, Alberto. Federalismo fiscal: el caso argentino. Buenos Aires: Editorial Tesis; Instituto Torcuato di Tella, 1990; PRESMAN, Jorge Alberto. La coparticipación de impuestos: del federalismo fiscal a centralismo menemista. Buenos Aires: Centro de Estudios para el Cambio Estructural (CECE), 1992. (Estudios. n. 5).

${ }^{276}$ ARGENTINA. Constitución de la Nación Argentina. Ley n. 24.430, artículo 44.
} 
Urresti e Cardozo advertem que essa imprecisão ocasiona a dupla exigência sobre o mesmo fato gerador, exercida pela Nação e pelas províncias: "Debido a que un mismo o semejante impuesto puede ser exigido por dos jurisdicciones tributarias distintas en virtud del mismo presupuesto de hecho legal y con respecto a un mismo período de tiempo; $[\ldots] ., 277$

São antigos os esforços para tentar reduzir as consequências negativas da sobreposição de tributos idênticos em solo argentino e a solução adotada foi atribuir ao poder federal a instituição e a cobrança dos principais tributos (diretos e indiretos), combinadas com uma eficiente e imediata transferência desses recursos para as províncias, que aderem ao pacto mediante a aprovação de uma lei provincial que aprova o convênio de divisão do produto arrecadado. ${ }^{278}$

Nos pactos firmados, as províncias obrigam-se ainda a não manter ou criar novos gravames análogos ao estabelecido para o poder federal. Esses instrumentos infraconstitucionais são utilizados para se evitar a existência de impostos concorrenciais sobre o consumo, no seio da Federação, reconhecidos como indutores da uniformização e simplificação do sistema tributário da Nação argentina. ${ }^{279}$

O processo de uniformização da tributação sobre o consumo iniciou-se na Federação argentina no ano de 1954 e teve como objetivo inicial harmonizar as diversas hipóteses de incidência praticadas por todas as províncias. Nessa fase, esboçou-se o modelo de instituição e cobrança pela União, com participação na receita das províncias, mas foi no ano de 1973 que a harmonização foi concretizada com a adoção do Imposto sobre o Valor Acrescido (IVA), conforme reforma implementada pela Lei n. 20.631, publicada em dezembro. ${ }^{280}$

\footnotetext{
${ }^{277}$ URRESTI, Esteban Juan; CARDOZO, Horacio Félix, Comentários sobre la instauración del impuesto al valor agregado en un Estado Federal, in Reforma tributária e Mercosul: a instituição do IVA no direito tributário brasileiro, cit., p. 148. Em relação à jurisprudência, arremata: "Merece destacarse que la dobre tributación intrafederal en el régimen constitucional Argentino, tiene su origen inmediato en el propio sistema constitucional, razón por la cual la Corte Suprema Justicia de la Nación en forma reiterada ha declarado que la superposición de tributos nacionales y provinciales no implica por si misma una violación de las normas constitucionales."

${ }^{278}$ URRESTI, Esteban Juan; CARDOZO, Horacio Félix, Comentários sobre la instauración del impuesto al valor agregado en un Estado Federal, in Reforma tributária e Mercosul: a instituição do IVA no direito tributário brasileiro, cit., p. 149-163.

${ }^{279}$ Os principais gravames nacionais, como o imposto sobre a renda e o imposto sobre o valor agregado, são leis nacionais, mas os ingressos arrecadados se distribuem entre a Nação e as províncias, de acordo com porcentagens preestabelecidas do Regime de Coparticipação Tributária (URRESTI, Esteban Juan; CARDOZO, Horacio Félix, Comentários sobre la instauración del impuesto al valor agregado en un Estado Federal, in Reforma tributária e Mercosul: a instituição do IVA no direito tributário brasileiro, cit., p. 148149).

${ }^{280}$ Posteriormente modificada em 1986 pela Lei n. 23.349 e atualmente regida pelo Decreto n. 280/97 (que republicou o texto ordenado da lei).
} 
Arquitetou-se o modelo de tributação sobre o consumo de bens e serviços, plurifásico e não cumulativo, instituído por lei nacional, fiscalização e receitas compartilhadas conforme a lei, devendo o fruto da arrecadação ser automaticamente direcionado às províncias, que por sua vez deveria ser partilhado com os municípios. A repartição da receita não prescindiria da adesão formal das províncias e, no silêncio delas, haveria a retenção dos fundos destinados ao seu território.

Quando entrou em vigor o IVA nacional, os dois impostos concorrenciais foram eliminados em prol da harmonização das legislações tributárias sobre o consumo de bens e serviços, a saber:

a) O Imposto sobre as Vendas, de competência nacional, monofásico, cumulativo e com receita compartilhada com as províncias.

b) O Imposto sobre as Atividades Lucrativas (IAL), de competência das províncias incidia sobre as vendas de bens e determinadas prestações de serviços, de natureza plurifásica e cumulativo.

Destaque-se que para aprovar a reforma proposta, além de prever a redistribuição direta e imediata da receita, assegurou-se uma nova redistribuição dos percentuais de participação na receita para as províncias e a garantia de uma distribuição mínima para o exercício seguinte, tendo como base os valores percebidos antes da entrada em vigor do novo ordenamento, por um ano. ${ }^{281}$

A modificação da tributação do consumo na Argentina poderia ser considerada um sucesso e possibilitaria uma futura harmonização no âmbito do Mercosul, não fossem dois fatos que merecem reparo: a reforma admitiu a permanência da cobrança pelo governo federal de impostos específicos sobre o consumo de bens e as províncias conseguiram aprovar o direito de criar um novo tributo pelo exercício de atividades com fins lucrativos, fazendo ressuscitar, sob nova nomenclatura, uma imposição sobre o faturamento das empresas. O imposto sobre ingressos brutos floresceu em todas as províncias.

Convivem, portanto, na Argentina, o IVA (nacional), os impostos especiais sobre o consumo de bens e serviços seletivos (nacional) e o imposto provincial sobre os ingressos brutos (provincial). Essa competência dupla tem forte impacto na possibilidade de harmonização das legislações tributárias no Mercosul e vem sendo questionada pelos doutrinadores argentinos. ${ }^{282}$

\footnotetext{
${ }^{281}$ Conforme leis de aprovação do IVA e do regime de repartição de receitas: Leis ns. 20.221/73 e 23.548/88.

${ }^{282}$ Há várias propostas de alteração do sistema tributário elaboradas por diversos segmentos da sociedade, para substituição do imposto das províncias sobre os ingressos brutos, por distorcer a concorrência, incidir
} 
Por fim, os municípios também podem instituir tributos, nos termos precisos das constituições das províncias. As leis gerais tributárias ou os códigos tributários das províncias delimitam a competência da tributação do consumo dessas unidades políticas, atribuindo-lhes a cobrança de taxas e impostos sobre a propriedade de imóveis rurais, urbanos e sobre a propriedade de veículos automotores. Não obstante a ausência de maiores restrições em relação à conformação dessas exações, há taxas que elegem flagrantemente, como base de cálculo, elementos típicos de impostos sobre o consumo, tornando mais complexa qualquer possibilidade de harmonização no âmbito do MERCOSUL. ${ }^{283}$

Postas essas balizas, passemos a analisar as espécies tributárias que alcançam o consumo nas Províncias Unidas do Rio da Prata ${ }^{284}$, consideradas relevantes para esta tese.

\subsubsection{Imposto geral sobre o consumo de bens e serviços (IVA)}

O IVA é um imposto instituído e cobrado pelo governo federal, plurifásico, não cumulativo, que alcança todas as fases do circuito econômico dos bens e serviços, admitindo-se a dedução do valor a pagar os créditos financeiros suportados nas aquisições alcançadas pelo mesmo tributo (imposto contra imposto).

As hipóteses de incidência alcançam as vendas de bens móveis, as obras realizadas, as locações de coisas móveis, as prestações de serviço em geral e a importação de bens móveis e prestações realizadas no exterior para serem utilizadas no país.

Adota, portanto, o sistema de tributação denominado "país de destino", ao gravar com o ônus tributário as importações e desonerar as exportações, assegurado ao exportador a manutenção, utilização ou devolução do imposto incidente nas aquisições vinculadas aos produtos ou serviços exportados.

\footnotetext{
em cascata e por ser cumulativo (GÓMEZ SABAINI, Juan Carlos; GAGGERO, Jorge A. Lineamientos para una reforma del sistema tributario Argentino. Proyecto PNUD ARG 93/009/CITAF-OEA, CITAF, nº. T-37, Buenos Aires: Centro Interamericano de Tributación y Administración Financiera (CITAF), 1997).

${ }^{283}$ É importante destacar que a Província de Chubut delegou aos municípios a administração, fiscalização e arrecadação do imposto sobre ingressos brutos, a partir de 1989, pela Lei n. 3.098, posteriormente modificada pela Lei n. 3.231. Esse é o único registro de tributação sobre o consumo, por impostos, que se realiza nos municípios de uma província.

284 "Artículo 35 - Las denominaciones adoptadas sucesivamente desde 1810 hasta el presente, a saber: Provincias Unidas del Río de la Plata; República Argentina, Confederación Argentina, serán en adelante nombres oficiales indistintamente para la designación del Gobierno y territorio de las provincias, empleándose las palabras 'Nación Argentina' en la formación y sanción de las leyes." (ARGENTINA. Constitución de la Nación Argentina. Ley n. 24.430).
} 
Os exportadores gozam de privilégios de poder aproveitar os créditos das aquisições relacionadas às exportações isentas e, na hipótese de acumulação, poderão utilizá-los para saldar outros tributos nacionais, solicitar a devolução em espécie ou solicitar autorização para a transferência do valor a terceiros interessados.

O contribuinte é quem, com habitualidade, realiza a venda de coisas móveis, operações de locação ou prestação de serviços, importação definitiva de coisas móveis e é tomador de prestações realizadas no exterior para serem utilizadas na Argentina. É a pessoa física ou jurídica que realize com habitualidade ou casualidade as hipóteses de incidência tributária, identificados na legislação como comerciantes, industriais, importadores e prestadores de serviços em geral.

A base de cálculo do imposto, nas operações e prestações realizadas dentro do território nacional, corresponde ao valor do fato imponível, ou seja, o preço cobrado pela transação, não se admitindo a inclusão do próprio tributo em sua base de cálculo e nem mesmo qualquer outro tributo interno que reconheça como hipótese de incidência o mesmo fato. É, portanto, um tributo calculado "por fora" do preço.

Nas importações, a base de cálculo é formada pelo valor aduaneiro utilizado para o cálculo dos tributos aduaneiros, acrescido destes, entretanto excluídos o IVA e impostos sobre o consumo concorrenciais.

A alíquota padrão vigente atualmente na Argentina encontra-se estabelecida em $21 \%$ (vinte e um por cento), podendo variar entre a alíquota reduzida de $10,5 \%$ (dez e meio por cento) para alguns produtos alimentícios, transporte de passageiros e animais vivos, até alcançar a alíquota máxima de $27 \%$ (vinte e sete por cento) para as telecomunicações.

A não cumulatividade é ampla, admitindo-se deduzir do imposto a pagar o montante integral do imposto cobrado nas aquisições de insumos, bem do ativo imobilizado e todos os demais vinculados às operações e prestações tributadas.

Para assegurar a neutralidade da tributação sobre o consumo, admite-se ainda a dedução ou o creditamento dos impostos seletivos ao consumo, também pertencentes à Nação. ${ }^{285}$

Apura-se o tributo devido mensalmente, exceto na hipótese de importação, quando deve-se recolher o IVA no momento do pagamento dos tributos devidos pela importação.

\footnotetext{
${ }^{285}$ Alguns impostos internos, tais como serviços de radiodifusão, sobre os combustíveis, sobre as entradas de espetáculos cinematográficos e sobre os videogramas gravados podem ser abatidos do valor a pagar do IVA. As contribuições patronais e sobre os vales refeição podem comutar-se como crédito na escrita fiscal do IVA.
} 
Há raros casos de isenção, alinhando-se à regra mundial de tributação sobre o consumo, consagrados na última etapa de circulação de livros, revistas, periódicos, serviços educativos, assistência sanitária, locação de móveis destinados à habitação, de forma que o benefício atinja o consumidor do bem ou do serviço.

Coadunamos com o posicionamento de Altamirano que, ao analisar o tributo, apresenta-o como um imposto simples, de fácil controle, favorável ao processo de integração econômica internacional, por buscar a neutralidade, permitir a devolução exata aos exportadores e ser amplamente não cumulativo. ${ }^{286}$

Pelo exposto, é possível extrair a seguinte regra-matriz do imposto:

Regra-matriz do IVA

\begin{tabular}{|l|l|}
\hline \multicolumn{2}{|l|}{ Hipótese: } \\
\hline \\
\hline Critério material & $\begin{array}{l}\text { Vender bens móveis e prestar serviços } \\
\text { Critério espacial }\end{array}$ \\
Âmbito territorial da Nação \\
Critério temporal & Momento da venda ou da prestação do serviço
\end{tabular}

\section{Consequentes:}

\begin{tabular}{|l|ll}
\hline Critério pessoal & Sujeito ativo: & A Nação \\
& Sujeito passivo: & Vendedores e prestadores de serviços \\
Critério quantitativo & Base de cálculo: & O valor da operação de venda ou da prestação de serviços \\
& $\begin{array}{ll}\text { Alíquota: } \\
\text { Tributo a recolher: }\end{array}$ & $\begin{array}{l}\text { Resultado do confronto de débitos-créditos apurados no mês. } \\
\end{array}$ \\
& Tributo sujeito a não cumulatividade.
\end{tabular}

\section{Regra-matriz do IVA na importação de mercadorias}

\begin{tabular}{|l|l|}
\hline \multicolumn{2}{|l}{ Hipótese: } \\
\hline $\begin{array}{l}\text { Critério material } \\
\text { Critério espacial }\end{array}$ & $\begin{array}{l}\text { Importar bens móveis do exterior; Importar serviços do exterior } \\
\text { Repartições alfandegárias }\end{array}$ \\
Critério temporal & O momento do pagamento dos tributos aduaneiros \\
\hline
\end{tabular}

${ }^{286}$ ALTAMIRANO, Alejandro C. Estrutura basica del Impuesto al Valor Agregado (IVA) en la Republica Argentina. In: BALTHAZAR, Ubaldo Cesar (Org.). Reforma tributária e Mercosul. Belo Horizonte: Del Rey, 1999. p. 71-96. 


\begin{tabular}{|l|ll|}
\hline \multicolumn{2}{|l|}{ Consequentes: } \\
\hline Critério pessoal & $\begin{array}{l}\text { Sujeito ativo: } \\
\text { Sujeito passivo }\end{array}$ & $\begin{array}{l}\text { A Nação } \\
\text { Importador }\end{array}$ \\
& Base de cálculo & O preço que servir de base para o cálculo dos tributos \\
& aduaneiros, acrescido do montante destes e exclusão do \\
& próprio imposto e de impostos nacionais internos que \\
& alcancem a mesma hipótese de incidência. \\
& Alíquota & Aquela prevista para as operações internas da mercadoria \\
& Tributo a recolher & Devido no momento do pagamento dos tributos aduaneiros \\
\hline
\end{tabular}

\subsubsection{Imposto sobre os ingressos brutos das províncias argentinas}

O Impuesto sobre los Ingresos Brutos (IIB) é um tributo de competência das províncias e alcança as atividades econômicas desenvolvidas nos seus territórios, de forma plurifásica e cumulativa.

Apesar dos entes tributantes gozarem de liberdade para a sua instituição e cobrança, a uniformidade normativa foi parcialmente alcançada pelos convênios multilaterais firmados pelas províncias a partir da década de 1950, quando a exação vigente ainda era o imposto sobre as atividades lucrativas, derrogado pela Lei do IVA. ${ }^{287}$

Os acordos buscaram eliminar as múltiplas imposições para as atividades desenvolvidas em mais de uma jurisdição e, para tanto, foi necessário harmonizar o critério material do imposto e estabelecer hipóteses de incidência idênticas em todo o território da Nação.

Os efeitos negativos que os impostos desta natureza ${ }^{288}$ causam na economia, no plano interno e no plano internacional, já são, de longa data, analisados pela Federação e,

\footnotetext{
${ }^{287}$ Diversos autores estudados fazem um breve retrospecto sobre esse período, mas a análise de Vitta, Grecchi e Ferullo é bastante esclarecedora. Destaque-se o seguinte trecho, a indicar a dimensão dos acordos firmados pelas províncias para solucionar os problemas apontados: "La aparición de estos convenios en la década de los años 50, marca el comienzo de una nueva etapa en el Derecho Fiscal Argentino, a crear una nueva rama que se há dado en llamar Derecho Fiscal Interprovincial; conjunto de normas de derecho público convencional tendiente a armonizar y coordinar los poderes fiscales autónomos, manteniendo los impuestos proprios de cada estado, pero subordinando su aplicación a principios y normas libremente pactuados entre ellos." (VITTA, José María; GRECCHI, Ana María; FERULLO, Claudio. Impuesto sobre los ingresos brutos: asimetrías que deben eliminarse. Buenos Aires: Consejo Federal de Inversiones, 2007. p. 6). No mesmo sentido: BULIT GOÑI, Enrique Guillermo. Convenio multilateral, distribución de ingresos brutos. Buenos Aires: Depalma, 1992.

${ }^{288}$ Cumulativo, incidência em cascata, com efeito piramidal e que dificulta a real apuração do seu valor para efeitos de devolução de tributos aos exportadores. Provoca distorções nos preços, incentiva a integração artificial de empresas e afeta a competitividade dos bens produzidos localmente. Nesse sentido: BULIT GOÑI, Enrique Guillermo. Impuesto sobre los ingresos brutos. 2. ed. actual. y ampl. Buenos Aires: Ediciones Depalma, 1997.
} 
inclusive, motivaram um compromisso nacional de reformulação deste tributo, conforme decisão consignada no Pacto Federal para el Empleo, la Producción y el Crescimiento, firmado no ano de 1993.

Precedido por estudos elaborados pelas principais universidades do país que assinalaram os efeitos distorcivos que o imposto cumulativo gera na economia ${ }^{289}$, o Pacto de 1993 almejou compelir todas as províncias a substituir o IIB por outro imposto geral sobre o consumo, que assegurasse a neutralidade tributária e a competitividade econômica ${ }^{290}$, o que de fato ainda não ocorreu.

Os debates sobre o tema permanecem em voga na doutrina argêntea e as principais sugestões apresentadas levam em consideração três saídas possíveis: (i) a adoção de um IVA estadual, plurifásico e não cumulativo; (ii) a criação de um imposto que incida exclusivamente nas vendas realizadas no varejo; (iii) uma junção ao IVA federal, combinado com a reversão integral do acréscimo dessa receita para as províncias (receita não compartilhada com o poder federal). ${ }^{291}$

Para a criação do mercado comum, no âmbito do Mercosul, a última hipótese é a que propicia a harmonização das legislações tributárias dos países integrantes do tratado internacional.

O resultado, até o momento insatisfatório, alcançou apenas as metas transitórias de uniformização de isenções para as atividades primárias e certa aproximação nas alíquotas vigentes nos territórios estaduais. ${ }^{292}$

Após análise da legislação das principais províncias da Federação Argentina ${ }^{293}$, podemos afirmar que há características comuns que se repetem na legislação de cada localidade, sendo possível estabelecer os parâmetros abaixo formulados.

\footnotetext{
289 “[...] las ineficiencias económicas que genera este gravamen llegó a las Provincias a comprometerse a reemplazarlo en el plazo de tres años, por otro impuesto general al consumo, que asegurara la neutralidad tributaria y la competitividad económica, a partir de la firma del Pacto Federal el 12 de agosto de 1993." (VITTA, José María; GRECCHI, Ana María; FERULLO, Claudio. Impuesto sobre los ingresos brutos: asimetrías que deben eliminarse. Buenos Aires: Consejo Federal de Inversiones, 2007. p. 1).

${ }^{290}$ CHAMATRÓPULO, M. Pacto Federal para el empleo, la producción y el crecimiento. Crónica Tributaria. Buenos Aires: Errepar: 1994. v. 1.

291 VITTA, José María; GRECCHI, Ana María; FERULLO, Claudio. Impuesto sobre los ingresos brutos: asimetrías que deben eliminarse. Buenos Aires: Consejo Federal de Inversiones, 2007. p. 1-6.

${ }^{292}$ SIMÓN, Jorge Hernán. Sustitución del impuesto sobre los ingresos brutos: trade off entre eficiencia económica y autonomía provincial. Rosário: UNR Editora, 2001. As províncias comprometeram-se a eliminar a tributação das etapas produtivas e estabeleceram o compromisso de fixar alíquotas de $1 \%$ para as atividades primárias, 1,5\% para a indústria, entre $2,5 \%$ e 3,5\% para o comércio e deixou livres os serviços.

${ }^{293}$ Foram analisadas as normas das principais províncias da República Argentina: (I) Código Fiscal de la Provincia de Buenos Aires, Lei n. 10.397/86 e Decreto n. 3.027/86; (ii) Código Tributario de la Provincia de Cordoba, Lei n. 6.006/97 e Decreto n. 574/12; (iii) Código Fiscal de la Provincia del Chubut, Lei XXIV, n. 38; (iv) Código Fiscal de la Provincia de Entre Rios, Decreto-Lei n. 6.505; (v) Código Fiscal de la
} 
A hipótese de incidência alcança os ingressos provenientes do exercício habitual a título oneroso do comércio, da indústria, das profissões, da locação de obras ou serviços, sendo irrelevante, sob a ótica fiscal, o resultado obtido, a natureza do sujeito que materializa a hipótese tributária e o lugar onde elas se realize.

A habitualidade é dispensada no exercício de profissões liberais, no fracionamento e na venda de lotes, na locação de imóveis, mas o tributo não grava o trabalho pessoal executado em relação de dependência, com remuneração fixa ou variável e o desempenho de cargos públicos.

Seguindo a regra mundial de tributação sobre o consumo, o imposto não é exigido sobre o faturamento de bens, serviços e qualquer outra atividade destinada ao exterior. Como corolário lógico, alcança as importações e as regras encontram-se estabelecidas nos convênio multilaterais que procuram evitar a concorrência desleal entre as províncias por meio do comércio exterior. Sendo assim, harmonizaram-se as alíquotas a serem aplicadas na importação no patamar de 2,5\% (dois e meio por cento) para todas as províncias, com exceção da Província de Buenos Aires, que estabeleceu a alíquota de 3\% (três por cento), a partir de 2013. ${ }^{294}$

Nas importações, as alíquotas são aplicadas sobre a base de cálculo utilizada para a cobrança dos tributos aduaneiros e o recolhimento do imposto deverá coincidir com a cobrança dessas exações.

Não há um consenso sobre a isenção do tributo sobre os eventuais reembolsos financeiros recebidos pelos contribuintes exportadores, embora o tema também tenha sido objeto de tentativa de aproximação legislativa proposta por algumas províncias.

A base de cálculo nas operações realizadas no território nacional corresponde ao somatório dos ingressos brutos ${ }^{295}$ recebidos pelo exercício das atividades gravadas, sendo de notar que não devem ingressar no cálculo do imposto os tributos nacionais que incidem sobre o consumo, ou seja, o IVA nacional e os impostos seletivos sobre o consumo.

Provincia de Mendoza, Lei n. 1.284/93 e Decreto n. 1.284/93; (vi) Código Fiscal de la Provincia del Neuquén, Lei n. 2.680/09; (vii) Código Fiscal de la Provincia de Salta. Decreto, Lei n. 9/75. Recomenda-se também a leitura deste artigo, que pretende traçar as principais diferenças entre os tributos vigentes na República Argentina, já que o nosso propósito foi estabelecer as similitudes: VITTA, José María; GRECCHI, Ana María; BRUNOTTI, A. Análisis comparativo sobre legislación provincial del Impuesto sobre Ingresos Brutos. Buenos Aires: Consejo Federal de Inversiones, 2004.

${ }^{294}$ ARGENTINA. Convenio Multilateral del 18.08.77; Decreto n. 707/2003 y Resolución n. 17/2013. Buenos Aires, 16 de mayo de 2013. Fíjase la alícuota de percepción a cuenta del Impuesto sobre los Ingresos Brutos: comercio exterior - importación. Disponível em: 〈http:www.infoleg.gov.ar〉. Acesso em: 05 ago. 2014.

295 Considera-se ingresso bruto o valor monetário recebido em razão das vendas, prestações de serviços ou outras atividades contempladas na hipótese de incidência tributária, exceto os tributos taxativamente enumerados na legislação local. 
Os contribuintes do imposto são as pessoas físicas, as sociedades (com ou sem personalidade jurídica) e todos aqueles que realizarem as hipóteses de incidência descritas na norma instituidora da exação.

A apuração e o ajuste do tributo são anuais, embora todas as províncias estudadas estabeleçam regras de antecipações mensais de recolhimentos, tornando o tributo devido ao longo de todo o ano calendário e sujeito a um ajuste declarativo ao cabo do exercício. ${ }^{296}$

Há poucas isenções concedidas pelos entes tributantes, fato que justifica a importância dessa fonte própria de recursos para todas as províncias, cobrada sobre uma base ampla de contribuintes.

Após esse estudo preliminar, é possível extrair a seguinte regra-matriz do Imposto sobre Ingressos Brutos vigente nas vinte e três províncias da República Argentina e na Cidade Autônoma de Buenos Aires:

\section{Regra-matriz do IIB incidente no mercado interno}

\begin{tabular}{|l|l|}
\hline \multicolumn{2}{|l|}{ Hipótese: } \\
\hline $\begin{array}{l}\text { Critério material } \\
\text { Critério espacial }\end{array}$ & $\begin{array}{l}\text { Auferir receita bruta pela pessoa física ou jurídica } \\
\text { Qualquer lugar no território da província }\end{array}$ \\
Critério temporal & O momento do auferimento da receita bruta \\
\hline
\end{tabular}

\section{Consequentes:}

\begin{tabular}{l|ll} 
Critério pessoal & Sujeito ativo: & As províncias \\
Sujeito passivo: & Pessoas físicas ou jurídicas que auferirem receita \\
Critério quantitativo & Base de cálculo: & O valor total da receita bruta \\
& Alíquota: & Variável entre $1 \%$ e $3,5 \%$ \\
Tributo a recolher: & Resultado da aplicação da alíquota sobre a base de cálculo \\
& Tributo cumulativo
\end{tabular}

\section{Regra-matriz do IIB da Argentina na importação de mercadorias:}

\begin{tabular}{|l|l|}
\hline \multicolumn{2}{|l|}{ Hipótese: } \\
\hline $\begin{array}{l}\text { Critério material } \\
\text { Critério espacial }\end{array}$ & $\begin{array}{l}\text { Importar bens e serviços } \\
\text { Repartições alfandegárias }\end{array}$ \\
Critério temporal & O momento do pagamento dos tributos aduaneiros
\end{tabular}

296 JARACH, Dino. Curso superior de derecho tributario. Ed. actualizada. Buenos Aires: Liceo Profesional CIMA, 1969. p. 163 e VIZCAÍNO, Catalina García. Derecho tributario: tomo 3: parte especial: el derecho tributario vigente: análisis de la legislación, doctrina y jurisprudência. Buenos Aires: Depalma, 1997. p. 314-315. 


\begin{tabular}{|c|c|c|}
\hline \multicolumn{3}{|l|}{ Consequentes: } \\
\hline \multirow[t]{2}{*}{ Critério pessoal } & Sujeito ativo: & As Províncias \\
\hline & Sujeito passivo: & O importador \\
\hline \multirow[t]{3}{*}{ Critério quantitativo } & Base de cálculo: & $\begin{array}{l}\text { O preço que servir de base para o cálculo dos tributos } \\
\text { aduaneiros, acrescido do montante destes e dos encargos } \\
\text { cambiais devidos pelo importador }\end{array}$ \\
\hline & Alíquota: & $\begin{array}{l}\text { A alíquota padrão é de } 2,5 \% \text {, com exceção da Província de } \\
\text { Buenos Aires, que exige a alíquota de } 3 \%\end{array}$ \\
\hline & Tributo a recolher: & $\begin{array}{l}\text { Calculado pela aplicação da alíquota sobre a base de cálculo, } \\
\text { recolhido no momento da exigência dos tributos aduaneiros }\end{array}$ \\
\hline
\end{tabular}

\subsubsection{Outros impostos nacionais sobre o consumo de bens e serviços}

Como também ocorre na União Europeia, a adoção do IVA como um imposto geral sobre o consumo de bens e serviços admite a convivência com impostos específicos sobre o consumo de determinados bens e serviços considerados especiais, como as bebidas alcoólicas, os cigarros, serviços financeiros, seguros, entre tantos outros que justifiquem serem tratados de forma distinta.

Para evitar os efeitos danosos que a tributação em cascata pode gerar em uma economia que se pretende globalizada, entende-se que se deve adotar a sistemática plurifásica e não cumulativa, alcançando a neutralidade físcal.

Nesse sentido, também vigora na Argentina, ao lado do IVA nacional, outros gravames específicos sobre determinados $\operatorname{produtos}^{297}$, em geral de natureza monofásica, cumulativos e de competência do poder central, submetidos à repartição de receitas, conforme modelo definido acordado com as províncias.

Para uma futura harmonização das legislações tributárias dos países membros do Mercosul, é imperioso citá-los, para que possam os produtos e serviços se sujeitar às regras da tributação seletiva em todos os países. Em outras palavras, no modelo ideal do mercado comum, podem conviver o imposto geral sobre o consumo (IVA) e os impostos especiais, entretanto devidamente articulados, de modo a alcançar os mesmos produtos, preferencialmente de forma plurifásica e não cumulativa.

\footnotetext{
297 A origem destes tributos, a evolução histórica e os problemas constitucionais que geram podem ser avaliados em: VIZCAÍNO, Catalina García. Derecho tributario: tomo 3: parte especial: el derecho tributario vigente: análisis de la legislación, doctrina y jurisprudência. Buenos Aires: Depalma, 1997. p. 199-236.
} 
Observa-se que, no caso argentino, para além das hipóteses de tributação especial sobre o consumo, aumentaram exponencialmente os impostos complementares incidentes sobre bases já gravadas, que poderão dificultar uma possível aproximação legislativa com os países do MERCOSUL. O quadro geral da atual tributação do consumo que excede o IVA, que enseja reparo em prol de uma futura harmonização tributária, pode ser resumido da seguinte forma:

(i) Impostos seletivos sobre o consumo de bens: tributo monofásico, calculado por dentro e cumulativo que alcança o fabricante ou os importadores de tabacos, bebidas alcoólicas e não alcoólicas, veículos e motores, objetos suntuosos, embarcações, aeronaves e produtos eletrônicos. A alíquota é variável por produto, entre $4 \%$ a $60 \%$.

(ii) Impostos seletivos sobre o consumo de serviços: tributo monofásico, calculado por dentro, cumulativo que alcança os Seguros e prestação de serviço de telefonia celular ou por satélite. As alíquotas variam de $1 \%$ a $23 \%$.

(iii) Imposto complementar sobre os combustíveis líquidos e o gás natural ${ }^{298}$ : imposto plurifásico que alcança a transferência onerosa ou gratuita efetuada por importadores, empresas refinadoras, empresas comercializadoras e, no caso do gás liquefeito para uso automotor, nos postos de combustíveis, os valores são cobrados por unidade de medida (pauta mínima) ou pela aplicação das alíquotas que variam entre 19\% e $70 \%$.

(iv) Imposto complementar da energia elétrica: Fundo Nacional de Energia Elétrica $^{299}$ : imposto monofásico que alcança a compra ou a importação de energia elétrica realizada por grandes usuários ou distribuidores. O imposto é fixo por unidade de medida $(\mathrm{kWh})$.

(v) Imposto adicional de emergência sobre $\operatorname{cigarros}^{300}$ : imposto adicional aplicado ao preço final de venda de cigarros. Aplica-se a alíquota de 7\%, mas admite a dedução do próprio imposto, do IVA e do Fundo Nacional do Tabaco.

(vi) Imposto sobre as entradas de espetáculos cinematográficos ${ }^{301}$ : imposto monofásico e exigido no ato da aquisição de entradas para espetáculos cinematográficos. $\mathrm{O}$ valor pago pode ser deduzido do valor a pagar de IVA devido pelo contribuinte. A alíquota é de $10 \%$.

\footnotetext{
${ }^{298}$ ARGENTINA. Congreso de la Nación Argentina. Ley n. 23.966/91.

${ }^{299}$ ARGENTINA. Congreso de la Nación Argentina. Leyes ns. 15.336/60 y 24.065/92.

${ }^{300}$ ARGENTINA. Congreso de la Nación Argentina. Ley n. 24.625/96 y Decreto n. 345/2006.

${ }^{301}$ ARGENTINA. Congreso de la Nación Argentina Leyes ns. 17.741/68 y 24.377/94.
} 
(vii) Imposto sobre a venda ou a locação videogramas gravados ${ }^{302}$ : monofásico, aplicado no momento da venda ou da locação de todo tipo de videograma gravado e destinado à exibição pública ou privada. Sobre o preço de venda ou locação, excluído o IVA, aplica-se a alíquota de $10 \%$. O valor pago pode ser descontado do IVA.

(viii) Imposto sobre os serviços de comunicação audiovisual: cobrado dos titulares dos serviços de comunicação audiovisual, sobre o faturamento bruto correspondente à comercialização de publicidade tradicional ou não tradicional ${ }^{303}$. As alíquotas variam entre $1 \%$ e $5 \%$.

(ix) Imposto complementar sobre o diesel e sobre o gás liquefeito para uso automotor $^{304}$ : imposto que recai sobre a transferência, a título oneroso ou gratuito, importação de diesel, monofásico, e também sobre a transferência de gás liquefeito para uso automotor, na hipótese de estações de carga para frotas próprias. Este tributo não é dedutível ou compensado com nenhum outro imposto nacional. A alíquota vigente é de $22 \%$.

(x) Imposto complementar sobre as naftas e o gás natural destinado a $\mathrm{GNC}^{305}$ : monofásico, incide sobre a transferência a título oneroso ou gratuito ou importação de nafta e sobre o gás natural distribuído por redes destinadas a gás natural comprimido para o uso em combustíveis automotores. As alíquotas oscilam entre 5\% e 9\%.

(xi) Imposto complementar sobre o abono de telefonia celular ${ }^{306}$ : destinado a promover o esporte olímpico, mediante a criação do ente nacional de alto rendimento desportivo (ENARD). A alíquota é de $1 \%$ sobre o preço cobrado pelas empresas de telefonia celular, exceto o pré-pago.

\subsection{Sistema tributário da República do Paraguai}

A Constitución de la República del Paraguay ${ }^{307}$ estabelece que o país é um Estado social de direito, unitário, indivisível e descentralizado. O território nacional é formado pelos departamentos, municípios e distritos, que gozam de certa autonomia política,

\footnotetext{
${ }^{302}$ ARGENTINA. Congreso de la Nación Argentina. Leyes ns. 17.741/68 y 24.377/94.

${ }^{303}$ ARGENTINA. Congreso de la Nación Argentina. Leyes n. 26.522/2009 y Decreto n. 1.225/2010.

304 ARGENTINA. Congreso de la Nación Argentina. Leyes ns. 26.028/2005, 26.454/2008, 26.942/2014 y Decreto n. 564/2005.

${ }^{305}$ ARGENTINA. Congreso de la Nación Argentina. Leyes ns. 26.181/2006 y 26.784/2012.

${ }^{306}$ ARGENTINA. Congreso de la Nación Argentina. Ley n. 26.573/2009 y Decreto n. 583/2010.

${ }^{307}$ PARAGUAY. Constitución de la Republica del Paraguay, de 20 de junio de 1992.
} 
administrativa e normativa, bem como poderes para arrecadar e gerir os seus recursos ${ }^{308}$, rigidamente delimitados pela Carta Constitucional e, principalmente, pelas leis editadas no Congresso paraguaio.

Norteado pelos princípios da legalidade ${ }^{309}$, da igualdade, vedação do confisco e respeito à capacidade contributiva ${ }^{310}$, o sistema tributário do Paraguai é composto por impostos, taxas e contribuições, sendo vedada constitucionalmente a bitributação, assim entendida como a dupla imposição sobre o mesmo fato gerador da obrigação tributária, o que representa uma importante limitação ao poder de tributar.

A Carta Republicana estabelece ainda o objetivo, respeitada a reciprocidade de tratamento, de o Estado buscar celebrar convênios e tratados internacionais para evitar a dupla imposição nas relações com terceiros países. ${ }^{311}$

Firmou-se o compromisso de adotar um sistema tributário que estimule a produção rural, desestimule o latifúndio e garanta o desenvolvimento da pequena e média propriedade rural, de acordo com a particularidade de cada região. ${ }^{312}$

Ao dispor sobre os direitos econômicos, o texto constitucional consagra a liberdade de circulação de mercadorias de produção nacional e os de procedência estrangeira, consagrando o conceito de mercado interno e a garantia de não discriminação dos produtos importados. 313

Há proibição constitucional de se estabelecer tributos sobre os objetos, as publicações e as atividades que possuam valor significativo para a difusão cultural e para a educação. Protege também das exações as artes e a investigação científica e tecnológica, assim como a sua difusão no país e no exterior ${ }^{314}$, além de prever a imunidade fiscal para a propriedade comunitária de terras dos povos indígenas. ${ }^{315}$

\footnotetext{
${ }^{308}$ PARAGUAY. Constitución de la Republica del Paraguay, artículo 156. CRIVELLI, Ernesto. El sistema impositivo de Paraguay desde una perspectiva regional. Departamento de Finanzas (FAD) DEL FMI. Washington, DC, 2010.

${ }^{309}$ Os artigos 44 e 179 da Constituição do Paraguai estabelecem que ninguém estará obrigado ao pagamento de tributos e nem a prestações de serviços pessoais que não tenham sido estabelecidos pela lei. Todo tributo, qualquer que seja a sua denominação, será estabelecido pela lei, respondendo a princípios econômicos e sociais justos, assim como a políticas favoráveis ao desenvolvimento nacional. A lei também deverá determinar as hipóteses de incidência, os sujeitos passivos e o perfil do sistema tributário.

${ }^{310}$ A igualdade é a base do tributo, conforme estabelece o art. 181 da CR/92. Ele não poderá ter caráter confiscatório e a sua criação e vigência atenderão à capacidade contributiva dos habitantes e às condições gerais da economia do país.

${ }^{311}$ PARAGUAY. Constitución de la Republica del Paraguay, artículo 180.

${ }^{312}$ PARAGUAY. Constitución de la Republica del Paraguay, artículo 115, 1.

${ }^{313}$ PARAGUAY. Constitución de la Republica del Paraguay, artículo 108.

${ }^{314}$ PARAGUAY. Constitución de la Republica del Paraguay, artículo 83.

${ }^{315}$ PARAGUAY. Constitución de la Republica del Paraguay, artículo 64.
} 
No tocante à repartição de competências e de receitas tributárias, a Constituição do Paraguai estabelece unicamente a divisão dos tributos que gravam a propriedade imóvel em forma direta: a sua arrecadação será de competência dos municípios, sendo que $70 \%$ (setenta por cento) da arrecadação pertence a estes territórios, 15\% (quinze por cento) é destinado ao respectivo departamento e os outros $15 \%$ (quinze por cento) para as municipalidades de menor recurso financeiro, estabelecendo, portanto, uma repartição norteada pelo princípio da igualdade e comprometida com a redução das desigualdades locais. $^{316}$

A lei tributária editada pelo Congresso ${ }^{317}$ (bicameral composto pelo Senado e Câmara dos Deputados) deverá dispor sobre as parcelas correspondentes aos demais impostos, taxas e contribuições que serão destinadas à administração departamental e aos municípios. $^{318}$

Os municípios, que são órgãos de governo local com personalidade jurídica, no âmbito de sua competência, jurisdição territorial e com observância às leis fiscais, poderão também instituir e cobrar taxas retributivas de serviços efetivamente prestados, vedado arrecadá-las em valor superior ao seu custo. ${ }^{319}$

Como garantia de repasse de receitas tributárias (que não é automático) e reforço financeiro aos municípios, há expressa previsão constitucional estabelecendo que nenhuma instituição do Estado, ente autônomo, autárquico ou descentralizado poderá apropriar-se de ingressos ou rendas das municipalidades, não se admitindo a possibilidade de editar leis no Congresso que disponham de forma distinta, como garantia de empréstimos públicos ou outro acordo de qualquer natureza.

O regime tributário paraguaio passou por uma profunda reforma ${ }^{320}$, que teve como objetivo primordial a reformulação da tributação do consumo, por meio da adoção do Imposto sobre o Valor Acrescido (IVA) plurifásico e não cumulativo, incidente sobre o fornecimento de bens e serviços, vigente desde janeiro de $1992 .^{321}$

\footnotetext{
${ }^{316}$ PARAGUAY. Constitución de la Republica del Paraguay, artículo 168, 3.

${ }^{317}$ As atribuições do Congreso Paraguayo estão estabelecidas no artigo 202 da Constituição e o item 4 prevê a responsabilidade de legislar sobre matéria tributária.

${ }^{318}$ PARAGUAY. Constitución de la Republica del Paraguay, artículos 164 e 166.

${ }^{319}$ PARAGUAY. Constitución de la Republica del Paraguay, artículo 168, 3.

${ }^{320}$ BORDA, Dionisio. Paraguay: resultados de las reformas (2003-2005) y sus perspectivas. Santiago de Chile: CEPAL, 2007. (Informes y Estudios Especiales, 18).

${ }^{321}$ Impostos revogados no Paraguai, quando da adoção do IVA: (i) imposto sobre as vendas de mercadorias e serviços; (ii) imposto sobre o gado; (iii) imposto junto; (iv) imposto sobre o papel e estampilhas; (v) imposto sobre as passagens aéreas; (vii) imposto para as empresas industrializadoras de carne; (viii) imposto sobre os espetáculos públicos (BLANCO, Sindulco. El impuesto al valor agregado en el Paraguay. In: BALTHAZAR, Ubaldo Cesar (Org.). Reforma tributária e Mercosul. Belo Horizonte: Del Rey, 1999.
} 
O sistema tributário paraguaio encontra-se atualmente regido pela Lei n. $125 / 91^{322} \mathrm{e}$ ancora-se em um modelo de repartição de competências bem simples: (i) ao governo central $^{323}$ compete a tributação sobre o comércio exterior, a renda e o consumo de bens e serviços; e (ii) os impostos sobre a propriedade pertencem ao poder subnacional. ${ }^{324}$

Na República paraguaia vigoram dois tributos sobre o consumo, de competência do poder central: o Imposto sobre o Valor Acrescido (IVA) e um imposto seletivo sobre o consumo, ambos fortemente influenciados pelo modelo europeu de tributação e bastante favoráveis à aproximação legislativa para o desenvolvimento do Mercosul. ${ }^{325}$

\subsubsection{Imposto geral sobre o consumo - o IVA do Paraguai}

O Impuesto sobre el Valor Agregado (IVA), que incide sobre a alienação ${ }^{326}$ e a importação de bens e sobre a prestação de serviços ${ }^{327}$, pertence ao poder central e adota o modelo plurifásico e não cumulativo. ${ }^{328}$

\footnotetext{
${ }^{322}$ PARAGUAY. Congreso. Ley n. 125/91, del 9 de enero de 1992 - Establece el Nuevo Régimen Tributario. As principais leis que alteram esta normativa são as seguintes: Leis ns. 2421/2004; 5.061/2013 e 5.143/2013. O decreto regulamentar vigente foi republicado sob o n. 1.030/2013. Disponíveis em: <http://www.set.gov.py>. Acesso em: 10 nov. 2014.

${ }^{323}$ Impostos vigentes: a) imposto de renda; b) IVA; c) imposto seletivo sobre o consumo; d) imposto sobre o comércio exterior.

${ }^{324}$ São eles: a) imposto sobre a propriedade; b) patente de comércio, indústria, profissões e ofícios; c) patente sobre os veículos; d) imposto imobiliário e sobre os terrenos baldios; e) imposto adicional ao imóvel de grande extensão; f) imposto sobre a transferência de bens de raiz.

${ }^{325}$ ZÁRATE, Walter. Efectividad de la política tributaria em Paraguay: antes y después de la Reforma. Asunción: CADEP-OFIP, 2010. Disponível em: <http://www.cadep.org.py/uploads/2009/05/Efectividad_Politica-_Tributaria.pdf $>$. Acesso em 02 dez. 2014.

${ }^{326}$ Considera-se alienação de bens (objetos materiais e imateriais suscetíveis de valor): (i) toda operação onerosa ou gratuita que tenha como fim transferir o direito de propriedade ou o domínio de bens em qualquer estado, ou de uma cota de domínio destes, outorgando ao destinatário a faculdade de dispor de ditos bens como se fosse seu proprietário, para seu uso, consumo, gozo, desfrute, armazenamento, posterior alienação ou qualquer outra forma de disposição dos mesmos; (ii) a retirada de bens da empresa realizada pelos donos, sócios, diretores ou empregados, para uso e consumo pessoal ou familiar ou qualquer outro destino; (iii) a doação em pagamento, as locações com opção de compra ou permuta; (iv) a cessão de cotas ou de ações de sociedades; (v) as adjudicações ao dono, sócios e acionistas, que se realizem por alterações na sociedade ou encerramento; (vi) os contratos de compromisso com transferência da posse do bem; (vii) a entrega de bens em consignação. "Para evitar equívocos, el Legislador ha aclarado el concepto de 'enajenación', a todos los efectos de la aplicación del Impuesto, dando una descripción que comprende el concepto civilista tradicional equivalente a transferencia onerosa del derecho de dominio sobre las cosas, sino que lo extiende incluso al supuesto de entrega gratuita de bienes a terceros, con poderes para usarlo y disfrutarlo, aunque no existiere efectivamente la tradición definitiva del derecho de propiedad." (BLANCO, Sindulco. El impuesto al valor agregado en el Paraguay. In: BALTHAZAR, Ubaldo Cesar (Org.). Reforma tributária e Mercosul. Belo Horizonte: Del Rey, 1999.

${ }^{327}$ Considera-se serviço a ação ou prestação que uma pessoa física ou jurídica realiza a favor de outra, seja em forma gratuita ou percebendo em troca preço, interesse, comissão ou qualquer outra forma de remuneração; bem como o autoconsumo de serviços em benefício dos donos, sócios, acionistas, diretores da empresa (PETTIT, Horacio Antonio. Legislación tributaria. Asunción, Paraguay: Intercontinental, 2008).
} 
A tributação do comércio exterior segue o consagrado modelo de tributação no destino, razão pela qual as exportações são exoneradas; os exportadores podem manter os créditos fiscais relacionados às aquisições vinculadas às mercadorias ou serviços exportados e as importações são gravadas pelo imposto.

Os contribuintes são as pessoas físicas ou jurídicas que realizam as hipóteses de incidência, entretanto o texto legal expressamente elenca como sujeitos passivos: (i) as pessoas físicas pelo exercício de profissões universitárias e as demais pessoas físicas pela prestação de serviços pessoais na forma independente; (ii) as empresas unipessoais domiciliadas no país, quando realizem atividades comerciais ou industriais, de serviço ou agropecuárias; (iii) as sociedades com ou sem personalidade jurídica; (iv) as entidades privadas em geral, assim como as pessoas domiciliadas ou entidades constituídas no exterior ou suas sucursais, agências ou estabelecimentos, quando realizem as atividades sujeitas ao tributo; (v) os importadores; (vi) as autarquias, empresas públicas, entidades descentralizadas e sociedades de economia mista que desenvolvam atividades comerciais, industriais ou de serviços; (vii) as entidades de assistência social, caridade, beneficência ou de instrução científica, literária, artística, de cultura física e desportiva, as associações, federações, fundações, corporações e demais entidade que praticarem atividades não exoneradas expressamente na lei.

O fato imponível nasce na entrega do bem ou, na hipótese de serviços, o que ocorrer primeiro: a emissão da fatura, a percepção do valor do serviço, na data do vencimento acordado ou na finalização do serviço prestado.

Nas importações, considera-se ocorrido o fato imponível no momento de registro da entrada dos bens na aduana. ${ }^{329}$

Para cálculo do imposto, deve-se tomar como base o preço correspondente à entrega dos bens ou da prestação de serviços, incluídas todas as importâncias cobradas do adquirente, deduzidos os descontos, as mercadorias devolvidas e as bonificações. ${ }^{330}$

$\mathrm{Na}$ entrega de bens a título gratuito, a norma prevê que deverá ser apurado o preço corrente no mercado interno, ou, no mínimo, adotado o preço de custo acrescido do montante de $30 \%$ dessa base.

\footnotetext{
${ }^{328}$ PARAGUAY. Congreso. Ley n. 125/91, del 9 de enero de 1992 - Establece el Nuevo Régimen Tributario, artículo 77.

${ }^{329}$ PARAGUAY. Congreso. Ley n. 125/91, del 9 de enero de 1992 - Establece el Nuevo Régimen Tributario, artículo 80.

${ }^{330}$ PARAGUAY. Congreso. Ley n. 125/91, del 9 de enero de 1992 - Establece el Nuevo Régimen Tributario, artículo 82.
} 
$\mathrm{Na}$ importação, a base de cálculo será o valor aduaneiro, acrescido dos tributos aduaneiros, mesmo quando esses tributos gozem de alguma suspensão, excluído o valor do próprio imposto $^{331}$. A única exceção diz respeito aos particulares, que não exercem as atividades listadas como contribuintes habituais, que deverão acrescer mais $30 \%$ do valor da base de cálculo na importação.

Em todos os casos, a base de cálculo inclui todos os demais tributos que afetem a operação, com exceção do próprio imposto.

As isenções estabelecidas na lei são bem reduzidas e alcançam: livros e periódicos, revistas de interesse educativo, científico ou cultural, produtos artesanais, combustíveis derivados de petróleo e biocombustíveis, bens doados a entidades educativas e desportivas sem fins lucrativos, computadores portáteis; serviços de educação prestados por entidades sem fins lucrativos, serviços prestados por entidades sem fins lucrativos de espetáculos culturais e desportivos, aluguel de prédio para essas entidades e serviços prestados gratuitamente por elas.

A apuração do imposto se faz pela sistemática de confrontos de débitos menos créditos, admitindo-se computar como crédito, além das aquisições de bens e serviços e do valor pago nas importações, as devoluções, as bonificações, os descontos e também as hipóteses de fatos considerados não passíveis de cobrança e definidos em lei.

O crédito, portanto, é amplo e de natureza financeira, mas deverá ser tomado em razão das operações ou prestações tributadas. As isenções e exonerações (salvo as decorrentes de exportação) não ensejam o aproveitamento de créditos fiscais. Sendo assim, caso o contribuinte realize operações tributadas e não tributadas, os créditos deverão ser calculados conforme a proporção de vínculo aos produtos e serviços exportados.

O saldo eventualmente remanescente poderá ser transferido para o mês subsequente, entretanto novas regras passaram a dificultar esse mecanismo: nas venda de bens ou prestações de serviços exoneradas ou não gravadas pelo imposto, o excedente de crédito fiscal do IVA ao final do exercício do IR não poderá ser utilizado nas liquidações posteriores, não será devolvido e será considerado como custo. Não se devolve nem mesmo pelo encerramento da atividade do contribuinte.

As entidades ou sujeitos que não possam trasladar o tributo proveniente de suas compras terão o tratamento de consumidores finais. Esses valores podem ser dedutíveis do IR.

\footnotetext{
${ }^{331}$ PARAGUAY. Congreso. Ley n. 125/91, del 9 de enero de 1992 - Establece el Nuevo Régimen Tributario, artículo 82 .
} 
Também é custo o restante de $50 \%$ dos créditos dos exportadores de produtos em estado natural ou primariamente industrializados. Não será crédito fiscal.

Os exportadores podem manter os créditos fiscais relacionados aos bens e serviços direta ou indiretamente vinculados aos produtos exportados, devendo tal crédito ser utilizado para o pagamento dos débitos internos. Se houver saldo acumulado, poderá ser utilizado para pagamento de outros tributos ou ainda devolvido ao contribuinte, no prazo máximo estabelecido em 60 dias.

Os contribuintes podem solicitar devolução acelerada, mediante garantia bancária ou financeira, no prazo de 15 dias; se o governo não cumprir os prazos, o contribuinte pode deduzir de suas obrigações com retenção ou do IR.

A alíquota padrão vigente é de $10 \%$, que será aplicada sobre o preço de venda ou prestação de serviços, embora também seja prática uma alíquota de 5\% para o arrendamento e venda de bens imóveis, para a venda de produtos agrícolas, frutícolas, hortícolas em estado natural e animais vivos, dos bens provenientes da caça e pesca, vivos ou não, e os artigos da cesta básica, arroz, erva mate, azeites, leite, ovos, carnes não cozidas, farinha e sal iodado, e produtos farmacêuticos.

A regra-matriz do tributo pode ser assim construída:

\section{Regra-matriz do IVA}

\section{Hipótese:}

Critério material $\quad$ Alienar bens móveis e imóveis e prestar serviços

Critério espacial Âmbito territorial do Estado unitário

Critério temporal Momento da alienação ou da prestação do serviço

\begin{tabular}{|c|c|c|}
\hline \multicolumn{3}{|l|}{ Consequentes: } \\
\hline Critério pessoal & Sujeito ativo: & Estado unitário \\
\hline \multirow{4}{*}{ Critério quantitativo } & Sujeito passivo: & $\begin{array}{l}\text { Pessoas físicas e jurídicas que alienarem bens móveis e } \\
\text { imóveis e prestarem serviços }\end{array}$ \\
\hline & Base de cálculo: & O valor da operação de alienação ou da prestação de serviços \\
\hline & Alíquota: & Padrão: $10 \%$ - Alíquota reduzida: $5 \%$ \\
\hline & Tributo a recolher: & $\begin{array}{l}\text { Resultado do confronto de débitos/créditos apurados no mês. } \\
\text { Tributo sujeito a não cumulatividade }\end{array}$ \\
\hline
\end{tabular}


Regra-matriz do IVA do Paraguai na importação de mercadorias:

\begin{tabular}{|c|c|c|}
\hline \multicolumn{3}{|l|}{ Hipótese: } \\
\hline Critério material & \multicolumn{2}{|c|}{ Importar bens móveis do exterior; Importar serviços do exterior } \\
\hline Critério espacial & \multicolumn{2}{|c|}{ Repartições alfandegárias } \\
\hline Critério temporal & \multicolumn{2}{|c|}{ O momento do pagamento dos tributos aduaneiros } \\
\hline \multicolumn{3}{|l|}{ Consequentes: } \\
\hline \multirow[t]{2}{*}{ Critério pessoal } & Sujeito ativo: & O Estado unitário \\
\hline & Sujeito passivo: & Importador ou quem utilizar serviço proveniente do exterior \\
\hline \multirow[t]{3}{*}{ Critério quantitativo } & Base de cálculo: & $\begin{array}{l}\text { O preço que servir de base para o cálculo dos tributos } \\
\text { aduaneiros, acrescido do montante destes e exclusão do } \\
\text { próprio imposto }\end{array}$ \\
\hline & Alíquota: & Aquela prevista para as operações realizadas no país \\
\hline & Tributo a recolher: & Devido no momento do pagamento dos tributos aduaneiros \\
\hline
\end{tabular}

\subsubsection{Imposto seletivo sobre o consumo}

O Impuesto Selectivo al Consumo (ISC), de incidência monofásica e cumulativa, alcança a importação ou a primeira saída do fabricante nacional dos seguintes produtos: cigarros, tabaco, bebidas alcoólicas e não alcoólicas, álcool carburante, combustíveis derivados de petróleo, perfumes, joias, eletrodomésticos, relógios, instrumentos musicais, armas e jogos recreativos. ${ }^{332}$

São contribuintes desse imposto os fabricantes, pelas alienações que promoverem no território nacional, e os importadores, pelos bens introduzidos no país.

As alíquotas variam conforme o produto e usualmente são praticadas taxas mínimas de $1 \%$ (eletrodomésticos, instrumentos musicais, jogos recreativos); médias de 5\% a $13 \%$ (perfumes, joias, relógios, bebidas, cigarros, armas e combustíveis não derivados de petróleo) e máximas de 50\% (combustíveis derivados de petróleo).

A obrigação tributária nasce na entrega dos bens e, na importação, no momento do desembaraço aduaneiro (que a legislação do Paraguai denomina de registro do processo na aduana).

\footnotetext{
${ }^{332}$ PARAGUAY. Congreso. Ley n. 125/91, del 9 de enero de 1992 - Establece el Nuevo Régimen Tributario. Arts. 99-118. As principais leis que alteram esta normativa são as seguintes: Leis ns. 2.421/2004; 5.061/2013 e 5.143/2013. O decreto regulamentar foi republicado sob o n. 1.030/2013 (Disponível em: <http: ॥www.set.gov.py>. Acesso em: 10 nov. 2014).
} 
O ISC não incide sobre as exportações dos produtos selecionados para essa forma distinta de tributação, entretanto inexiste na legislação tributária paraguaia a previsão de devolução aos exportadores do tributo incidente nas etapas antecedentes à exportação, como usualmente ocorre na tributação sobre o consumo. Tal empecilho às exportações ocorre principalmente por se tratar de um tributo cumulativo, monofásico e incidente nas primeiras etapas de circulação da mercadoria, fatos que dificultam a apuração do montante a ser ressarcido ao contribuinte.

A base de cálculo, nas operações realizadas dentro do território nacional, corresponde ao preço de venda na fábrica, excluído o próprio imposto e também o IVA. Na importação, a base de cálculo será formada pelo valor aduaneiro, acrescido dos tributos devidos pela importação (mesmo que se encontrem suspensos), exceto o próprio ISC e o IVA.

A apuração do tributo é mensal, com exceção dos combustíveis, que ensejam recolhimentos semanais.

Para uma futura harmonização tributária no Mercosul, este imposto seletivo deverá contemplar os mesmos produtos eleitos por todos os Estados membros e, preferencialmente, honrar a plurifasia e a não cumulatividade.

Dessa forma, o vigente Imposto Seletivo sobre o Consumo do Paraguai conforma a seguinte regra-matriz:

\section{Regra-matriz do ICS}

\begin{tabular}{|c|c|c|}
\hline \multicolumn{3}{|l|}{ Hipótese: } \\
\hline Critério material & \multicolumn{2}{|c|}{ Importar ou promover a primeira saída de produtos específicos } \\
\hline Critério espacial & \multicolumn{2}{|c|}{ Âmbito territorial da Nação } \\
\hline Critério temporal & \multicolumn{2}{|c|}{ Momento da primeira venda ou da importação } \\
\hline \multicolumn{3}{|l|}{ Consequentes: } \\
\hline \multirow[t]{2}{*}{ Critério pessoal } & Sujeito ativo: & O Estado Unitário \\
\hline & Sujeito passivo: & Importadores e primeiros vendedores de produtos específicos \\
\hline \multirow[t]{3}{*}{ Critério quantitativo } & Base de cálculo: & $\begin{array}{l}\text { O valor da importação, acrescido dos tributos aduaneiros ou o } \\
\text { valor da primeira saída }\end{array}$ \\
\hline & Alíquota: & Variável entre $1 \%$ a $50 \%$ \\
\hline & Tributo a recolher: & $\begin{array}{l}\text { Resultado da aplicação da alíquota sobre a base de cálculo. } \\
\text { Tributo cumulativo. }\end{array}$ \\
\hline
\end{tabular}




\subsection{Sistema Tributário da República Oriental do Uruguai}

A República Oriental do Uruguai é um Estado democrático, unitário, descentralizado ${ }^{333}$ e formado pelos governos departamentais e pelas autoridades locais. ${ }^{334}$

A Constitución de la República Oriental del Uruguay ${ }^{335}$ também não contém um capítulo dedicado ao sistema tributário nacional e tampouco positivou princípios ou limitações ao poder de tributar que vão além da exigência secular ${ }^{336}$ de estrita legalidade para a criação de tributos.

O poder legislativo é exercido pela Assembleia Geral, formada pela Câmara dos Representantes e pelo Senado, sendo que compete a ela instituir, suprimir, modificar e aumentar os tributos da nação, mediante lei aprovada pela maioria absoluta do total de componentes de cada Câmara. ${ }^{337}$

Se por um lado o poder de tributar concentra-se no Poder Legislativo, as hipóteses de concessão de benesses fiscais não concernem ao Congresso, já que o texto constitucional determina que as exonerações são de iniciativa privativa do Poder Executivo. $^{338}$

Os dezenove departamentos, incluída a capital Montevidéu, gozam de personalidade jurídica; possuem relativa autonomia administrativa, política e orçamentária, além de contar com recursos próprios decorrentes da fiscalização e cobrança dos tributos

333 URUGUAY. Constitución de la República Oriental del Uruguay de 1967, con las modificaciones plebiscitadas el 1989, 1994, 1996 e 2004, artículos $1^{\text {o }}, 24$ e 60.

${ }^{334}$ Os municípios foram criados recentemente, com a edição das Leis ns. 18.567/2009 e 18.653/2010. Segundo Veneziano: "La reforma constitucional que da lugar a la Constitución de 1997 (la vigente) señala algunos ítens que serán desarrollados en la Ley de Descentralización y Participación en el 2009 y del 2010. Esa reforma Constitucional se priorizó la descentralización desde el Gobierno Nacional a los Gobiernos Departamentales (primer nivel subnacional) pero establece algunos principios para la descentralización hacia los gobiernos locales (o 'autoridades locales' como los denomina el texto) para que una ley de descentralización Departamental los desarrolle."(VENEZIANO, Alicia. Análisis de redes intergubernamentales de las leyes de descentralización en Uruguay: por primera vez existen municipios. Revista Estudos de Política, Campina Grande, PB, v. 1, n. 1, p. 90, 2012).

${ }^{335}$ URUGUAY. Constitución de la República del Uruguay de 1967, con las modificaciones plebiscitadas el 1989, 1994, 1996 e 2004.

${ }^{336} \mathrm{O}$ princípio da legalidade em matéria tributária remonta à Carta Magna de João Sem Terra, de 1215. O rei, enfraquecido e subjulgado às exigências da nobreza, aceitou que a cobrança de tributos estaria condicionada ao consentimento do conselho do reino de Inglaterra (COÊLHO, Sacha Calmon Navarro. O princípio da legalidade: o objeto da tutela. In PIRES, Adilson Rodrigues; TÔRRES, Heleno Taveira. (Orgs.). Princípios de direito financeiro e tributário: estudos em homenagem ao Professor Ricardo Lobo Torres. Rio de Janeiro: Renovar, 2006).

337 URUGUAY. Constitución de la República Oriental del Uruguay de 1967, con las modificaciones plebiscitadas el 1989, 1994, 1996 e 2004, artículos 83, 84,85 e 87.

338 URUGUAY. Constitución de la República Oriental del Uruguay de 1967, con las modificaciones plebiscitadas el 1989, 1994, 1996 e 2004. Artículo 133. 
incidentes sobre o patrimônio de bens imóveis e veículos ${ }^{339}$. Contudo, a sua principal receita é oriunda da arrecadação dos tributos nacionais, conforme repartição de receita tributária estabelecida na legislação infraconstitucional, em obediência ao estabelecido pela Constituição da República. ${ }^{340}$

Seguindo os ditames constitucionais de maior descentralização, foram criados recentemente, por lei, oitenta e nove municípios que receberam funções delegadas pelos governos central e departamental. Embora denominados como "terceiro nível de governo"341, não possuem funcionários ou recursos próprios. Financeiramente, dependem da repartição da receita tributária arrecadada pelos poderes central e departamental. ${ }^{342}$

Por outro lado, se padece aos municípios a possibilidade de instituir, fiscalizar ou arrecadar tributos, a capacidade dos governos departamentais pode ser ampliada, já que há autorização constitucional para o Poder Executivo encaminhar ao Congresso um projeto de lei que, para ser aprovado, não poderá contemplar sobreposição em relação aos gravames já existentes e dependerá da aprovação da maioria absoluta do total de componentes de cada Câmara.

A mesma norma poderá estabelecer privilégios fiscais para empresas se estabelecerem no interior do país, em prol do desenvolvimento econômico regional, o que

339 URUGUAY. Constitución de la República Oriental del Uruguay de 1967, con las modificaciones plebiscitadas el 1989, 1994, 1996 e 2004, art. 297. Note-se que a prerrogativa de instituição é do parlamento, mas a fiscalização e arrecadação foram atribuídas ao governo departamental.

${ }^{340}$ Segundo Valdés, a Constituição de 1967 dispôs que estes impostos seriam sancionados pelo Poder Legislativo e que o seu produto pertenceria aos governos departamentais respectivos e inovou ao declarar como receita um percentual dos recursos nacionais, fixados em lei, um verdadeiro complemento à autonomia, por via constitucional (VALDÉS, Ramón Costa. El principio de legalidade: el sistema uruguayo ante el derecho comparado. In: El principio de legalidad en el Derecho Tributario. Obra colectiva conteniendo los trabajos presentados al Simposio organizado por la Facultad de Derecho y Ciencias Sociales y el Instituto Uruguayo de Estudios Tributarios en octubre de 1986. Montevideo: Facultad de Derecho, 1986. p. 179-222. O autor critica a repartição mal desenhada na Constituição Uruguaia ao rechaçar o modelo que abandou o exemplo do direito comparado de repartição de receitas dos modelos federais e lamenta a ausência de definição constitucional que assegure maior autonomia para o poder local (Ibidem, p. 3-44).

${ }^{341}$ URUGUAY. Parlamento. Ley n. 18.567, del 13 de setiembre del 2009. Ley de Descentralización y Participación Ciudadana, Montevideo, 2009. "Artículo $1^{\circ}$ - De acuerdo con lo previsto por los artículos 262, 287 y disposición transitoria y de la Constitución de la República, habrá una autoridad local que se denominará Municipio, configurando un tercer nivel de Gobierno y de Administración."

${ }^{342}$ URUGUAY. Constitución de la República Oriental del Uruguay de 1967, con las modificaciones plebiscitadas el 1989, 1994, 1996 e 2004. Artículo 19. Segundo Alícia veneziano: “[...] los Gobiernos Municipales son un tercer nivel gubernamental, que se vincula de distintas formas a los otros niveles de gobiernos formando parte del sistema político-institucional nacional, departamental y local. Gobierno multinivel en el cual se establecen Relaciones Inter-Gubernamentales (RIG) territoriales. [...] Sin embargo, lo segundo que debemos decir es que esta creación de GM no es una descentralización, en sentido jurídico estricto, ya que los órganos creados no tienen personalidad jurídica, ni recursos propios (no pueden recaudar) teniendo, así, una autonomía relativa." (VENEZIANO, Alicia. Análisis de redes intergubernamentales de las leyes de descentralización en Uruguay: por primera vez existen municipios. Revista Estudos de Política, Campina Grande, PB, v. 1, n. 1, p. 86, 2012). 
representa uma garantia de inexistência de guerras fiscais entre os departamentos que pretendam atrair contribuintes para o seu território, em detrimento dos demais, por meio de redução da carga tributária. A decisão pelo tipo de fomento a ser concedido e a sua localização no território nacional pertencem ao poder central. ${ }^{343}$

A Carta Magna estabelece que o Estado é o responsável por conduzir e fomentar o comércio exterior da República, cabendo a ele proteger as atividades econômicas que destinam seus produtos à exportação e, ao Parlamento (que deverá editar leis específicas sobre o tema), a tarefa de definir a fonte dos recursos e os investimentos necessários para alcançar o objetivo de favorecer as exportações. ${ }^{344}$

Esse é, portanto, o perfil constitucional da matéria tributária na República do Uruguai e, na ausência de definição das espécies tributárias, as leis, bem como a doutrina e a jurisprudência, adotaram a teoria tripartite de classificação dos tributos, ao estabelecer que a base do sistema tributário da República é formada por impostos, taxas e contribuições de melhoria. ${ }^{345}$

Vigora no país um Código Tributário Nacional $^{346}$ que contém regras gerais aplicáveis a todos os tributos, mas a norma que promoveu uma profunda reforma tributária $^{347}$ em solo uruguaio, e que atualmente rege o sistema tributário impositivo do país, é a Lei n. 18.083/2006 ${ }^{348}$. A reforma estrutural implementada, notadamente dirigida à tributação indireta, culminou com a eliminação dos impostos monofásicos e cumulativos e a adoção de dois tributos que incidem sobre o consumo, seguindo o padrão mundial das economias modernas: o Imposto sobre o Valor Agregado (IVA) e o Imposto Seletivo sobre o Consumo (ISC). ${ }^{349}$

${ }^{343}$ URUGUAY. Constitución de la República Oriental del Uruguay de 1967, con las modificaciones plebiscitadas el 1989, 1994, 1996 e 2004. Artículo 298.

${ }^{344}$ URUGUAY. Constitución de la República Oriental del Uruguay de 1967, con las modificaciones plebiscitadas el 1989, 1994, 1996 e 2004. Artículo 50.

${ }^{345}$ VALDES, Nelly. El impuesto al valor agregado em el Uruguay. In: BALTHAZAR, Ubaldo Cesar (Org.). Reforma tributária e Mercosul: a instituição do IVA no direito tributário brasileiro. Belo Horizonte: Del Rey, 1999. p. 98.

${ }^{346}$ URUGUAY. Parlamento: Ley 14.303/74. Código Tributario.

347 VENEZIANO, Alicia. Desafíos e incertidumbres de la descentralización en Uruguay: impactos de la reforma constitucional. Revista Prisma, Montevideo, UCUDAL, n. 13, 2000.

${ }^{348}$ URUGUAY. Parlamento: Ley n. 18.083/2006. Sistema Tributario. Se derogan, crean y modifican diversas normas.

${ }^{349}$ Para provomer as alterações e modernizar o IVA, a nova legislação derrogou os seguintes tributos: (i) impuesto a las retribuciones personales (IRP); (ii) impuesto de contribución al financiamiento de la seguridad social (COFIS); (iii) impuesto a los activos de las empresas bancarias (IMABA); (iv) impuesto de control del sistema financiero (icosifi); (v) impuesto específico a los servicios de salud (IMESSA); (vi) impuesto a las pequeñas empresas (ipeque); (vii) impuesto a las comisiones (ICOM). (viii) impuesto a las telecomunicaciones (itel); (ix) impuesto a las tarjetas de crédito (ITC); (x) impuesto a las ventas forzadas (IVF); (xi) impuesto a las rentas agropecuarias (IRA); (xii) impuesto a las cesiones de derechos sobre 


\subsubsection{O imposto geral sobre o consumo: o IVA}

Assim como o Brasil ${ }^{350}$, o Uruguai foi pioneiro em adotar um imposto sobre o consumo similar ao idealizado pelo francês Maurice Lauré: plurifásico, não cumulativo, liquidado pelo método de subtração (débitos-créditos), instituído e cobrado pelo poder central. $^{351}$

O perfil atual do imposto foi redefinido na reforma tributária implementada pela Lei n. 18.083/2006 ${ }^{352}$, que alargou as hipóteses de incidência, revogou uma série de exações que incidiam sobre o consumo de bens e serviços específicos e muito contribuiu para tornar o IVA a principal fonte de arrecadação da República Oriental do Uruguai. ${ }^{353}$

O imposto incide sobre a circulação interna ${ }^{354}$ e a importação de bens; sobre a prestação de serviços ${ }^{355}$ e sobre o acréscimo de valor oriundo de construção realizada em imóveis ${ }^{356}$. Por ser um imposto de caráter nacional, encontra-se fora das potestades tributárias dos governos departamentais, fato que, segundo Valdes ${ }^{357}$, evita possíveis

deportistas; (xiii) impuesto a la compraventa de bienes muebles en remate público; (xiv) impuesto a los concursos, sorteos y competencias (ICSC).

${ }^{350}$ Embora o Brasil tenha se inspirado na taxe sur la valeur ajoutée francesa para criar o antigo ICM, atribuiu aos Estados e Distrito Federal a competência para instituí-lo e cobrá-lo, ao contrário de destiná-lo à União. Ademais, limitou as hipóteses de crédito do imposto cobrado nas etapas antecedentes, o que desnaturou o tributo.

${ }^{351}$ O tributo foi instituído pela Lei n. 13.637/67. Denominado, originalmente, imposto sobre as vendas e serviços vigorou apenas por cinco anos e foi substituído pelo imposto sobre o valor acrescido (IVA), na primeira reforma tributária ocorrida no país, promovida pela Lei n. 14.100, de 29 de dezembro de 1972. A nova exação passou a alcançar a circulação de bens, a prestação de serviços e também as importações (VALDES, Nelly. El impuesto al valor agregado em el Uruguay. In: BALTHAZAR, Ubaldo Cesar (Org.). Reforma tributária e Mercosul: a instituição do IVA no direito tributário brasileiro. Belo Horizonte: Del Rey, 1999. p. 97-124.

352 URUGUAY. Parlamento. Ley n. 18.083, de 27/12/2006. Sistema Tributário: se derogan, crean y modifican diversas normas.

${ }^{353}$ GONZÁLEZ, Gustavo; MONTERO Marcelo, OLMOS Leticia e PELÁEZ Fernando. Un diseño de IVA personalizado. Focalización de benefícios fiscales de acuerdo a la capacidad contributiva. Revista Jornadas Tributarias: Montevideo, 2011. p. 1-46. p. 2.

${ }^{354}$ Por circulação de bens se entende toda operação a título oneroso que tenha por objeto a entrega de bens com transferência de propriedade e o consumo privado dos bens da empresa efetuado por seus donos, sócios ou acionistas. (URUGUAY. Parlamento. Ley n. 19.149/2013, artículos $2^{\circ}$ e 361).

${ }^{355}$ Por serviço se entenderá toda prestação a título oneroso que, sem constituir uma alienação, proporcione à outra parte uma vantagem ou proveito que constitua a causa da contraprestação (VALDES, Nelly. El impuesto al valor agregado em el Uruguay. In: BALTHAZAR, Ubaldo Cesar (Org.). Reforma tributária e Mercosul: a instituição do IVA no direito tributário brasileiro. Belo Horizonte: Del Rey, 1999. p. 101).

${ }^{356}$ Por agregação de valor na construção sobre imóveis se entenderá a realização de obras sob a modalidade de administração, quando tais imóveis não estejam afetados à realização de atividades que gerem ingressos de IVA, nem rendas computáveis para o imposto de renda ou imposto sobre a venda de bens agropecuários (URUGUAY. Parlamento. Ley n. 18.082/2006, artículo 15).

${ }^{357}$ VALDES, Nelly. El impuesto al valor agregado em el Uruguay. In: BALTHAZAR, Ubaldo Cesar (Org.). Reforma tributária e Mercosul: a instituição do IVA no direito tributário brasileiro. Belo Horizonte: Del Rey, 1999. p. 99). 
conflitos que possam surgir entre os entes titulares da competência, como vem ocorrendo em larga escala no Brasil (guerras fiscais e conflitos de competência).

O fato imponível se configura mediante a entrega ou a introdução de bens no país, a concretização da prestação dos serviços e na, hipótese de construção em imóveis, quando a obra é finalizada.

Não são tributadas as exportações de bens, mas, curiosamente, para os serviços destinados ao exterior compete ao Poder Executivo determinar as hipóteses que serão abrangidas pela isenção. Tome-se como exemplo a isenção concedida aos serviços hoteleiros prestados a não residentes, como meio de fomentar o turismo e facilitar a devolução do tributo que antes ocorria nas aduanas, quando do regresso do não residente ao seu país de origem. ${ }^{358}$

Os contribuintes são os comerciantes, industriais, importadores, prestadores de serviços em geral, as pessoas físicas ou jurídicas que introduzam bens gravados no país ${ }^{359}$ e aqueles que promovem construção em imóveis.

A base de cálculo é formada pelo valor corresponde ao da contraprestação pela entrega da bem, pelo serviço prestado. Quando se tratar de importação, o critério quantitativo é definido a partir do valor do bem, acrescido dos tributos aduaneiros incidentes na importação e, caso seja promovida por um não contribuinte do imposto, agrega-se à base o percentual de 50\% (cinquenta por cento), antes de aplicar a alíquota correspondente. Nos fatos geradores decorrentes de obras realizadas em imóveis, a base de cálculo é formada pela duplicação do valor dos gastos realizados, admitida a dedução do IVA suportado nas aquisições de bens e serviços. ${ }^{360}$

As alíquotas em vigor no Uruguai são apenas duas: uma alíquota padrão de $22 \%$ (vinte e dois por cento) e uma alíquota reduzida de $10 \%$ (dez por cento) ${ }^{361}$, aplicadas aos produtos da cesta básica e serviços essenciais ou de primeira necessidade, tais como pães e biscoitos, pescado, carne, azeites, arroz, farinhas sal, açúcar, café, erva mate, sabonete, óleos comestíveis, transporte de leite, medicamentos, serviços vinculados à saúde,

\footnotetext{
${ }^{358}$ URUGUAY. Parlamento. Lei n. 17.555, de 18/09/2002. O artigo 62 estabelece, por exemplo, que o Poder Executivo poderá incluir no conceito de exportação os serviços prestados por hotéis relacionados com hospedagem a não residentes.

${ }^{359}$ URUGUAY. Parlamento. Decreto Ley n. 15.132/81, artículo $1^{\circ}$.

${ }^{360}$ URUGUAY. Parlamento. Ley n. 18.341/2008, artículo 18.

${ }^{361}$ URUGUAY. Parlamento. Ley n. 18.083/2006, artículo 25.
} 
transporte terrestre de passageiros, a primeira alienação de bens imóveis, frutas, flores e hortaliças. $^{362}$

Por outro lado, há um número muito elevado de hipóteses de não incidência ${ }^{363}$ catalogadas na norma instituidora do tributo, algo desaconselhável quando se refere a impostos que alcançam o consumo, ora por causar distorções na cadeia de circulação de produtos e serviços, quando a dispensa ocorrer apenas em algumas etapas desse circuito, ou por flagrante ofensa aos princípios da igualdade e do respeito à capacidade contributiva. $^{364}$

As principais exonerações estão previstas nos artigos 19 a 79 do Texto Ordenado do IVA $^{365}$, dentre as quais se destacam: (i) a alienação dos seguintes bens: metais preciosos, bens imóveis, exceto a primeira comercialização, combustíveis, livros e congêneres; fornecimento de água para consumo familiar; (ii) os serviços de financiamentos e demais transações financeiras, arrendamento de imóveis, seguros e cultivos agrícolas; (iii) a importação de bens isentos, de petróleo cru e veículos de transporte coletivo.

O crédito é de natureza financeira ${ }^{366}$, vez que admite o aproveitamento do imposto incidente nas compras de bens e serviços adquiridos pelo sujeito passivo, inclusive oriundo das importações. Exige-se apenas que as aquisições estejam, direta ou indiretamente, vinculadas ao custo de bens e serviços comercializados ou destinados ao exterior. As operações realizadas com isenção ou não incidência não geram o crédito do tributo, com exceção na hipótese de mercadorias destinadas ao exterior, como já apontado. Inclusive, nos casos de exportação, além de serem preservados os créditos oriundos das aquisições,

\footnotetext{
362 Interessante proposta, patrocinada pelos comerciantes que pagam altas taxas administrativas às administradoras de cartões foi recentemente aprovada no Parlamento: quando o pagamento for realizado por meio de cartão de débito, há redução de dois pontos percentuais da alíquota do IVA, desde que seja realizada na alienação de bens e prestações de serviços efetuadas a consumidores finais, conforme as Leis n. 18.910/2012 e 19.210/2014.

${ }^{363}$ GONZÁLEZ, Gustavo; MONTERO Marcelo, OLMOS Leticia e PELÁEZ Fernando. Un diseño de IVA personalizado. Focalización de benefícios fiscales de acuerdo a la capacidad contributiva. Revista Jornadas Tributarias: Montevideo, 2011.p. 1-46. p. 7.

${ }^{364}$ VALDÉS COSTA, Ramón. Protección de los derechos del contribuyente a nivel internacional. Revista Tributaria, Montevideo, Instituto Uruguayo de Estudios Tributarios (IUET), v.15, n. 84, p. 207-231, mayo/junio 1988.

${ }^{365}$ As normas legais referentes aos distintos impostos de competência do governo central foram ordenadas em um documento denominado Texto Ordenado. O texto vigente foi aprovado pelo Decreto n. 338, publicado em 28.08.1996, com a promessa de ser periodicamente atualizado.

${ }^{366}$ Há restrição ao crédito dos veículos de passeio, podendo gerar créditos apenas os de carga utilizados pela empresa, regra similar ao ICMS dos Estados e do Distrito Federal, no Brasil.
} 
poderão ser utilizados para pagamento de outros tributos nacionais ou devolvidos em moeda corrente aos exportadores. ${ }^{367}$

Outro elemento de destaque, favorável aos contribuintes uruguaios e que poderia ser adotado por todos os países do MERCOSUL, refere-se à possibilidade de restituição ou dispensa do tributo quando se comprovar que a contraprestação não foi realizada pelo adquirente dos bens e serviços, nas hipóteses de insolvência do devedor, decorrente de decisão judicial, rescisão do contrato, concessão de bonificação, descontos ou por qualquer outra causa alheia à vontade do contribuinte, prevista em lei. Esse permissivo alinha-se integralmente ao princípio do respeito à capacidade contributiva do cidadão contribuinte. $^{368}$

Em relação ao crédito do imposto porventura acumulado, ao final do mês é transferido para o período de apuração subsequente, não comportando devolução em espécie. Na reforma tributária promovida em 2006, foi aprovado um mecanismo prejudicial ao contribuinte, ao estabelecer que no final do exercício, os créditos remanescentes $^{369}$ deverão ser incluídos no custo das vendas (o que corresponde dizer que serão excluídos da apuração do imposto), um retrocesso à não cumulatividade ampla que foi adotada pelo Uruguai, na segunda metade do século $\mathrm{XX}^{370}$. Destaque-se que esse procedimento de anulação do saldo credor não alcança os exportadores.

\section{Regra-matriz do IVA}

\begin{tabular}{|l|l|}
\hline \multicolumn{2}{|l|}{ Hipótese: } \\
\hline Critério material & $\begin{array}{l}\text { Alienar bens móveis e imóveis e prestar serviços } \\
\text { Aritério espacial }\end{array}$ \\
Aritério temporal territorial nacional \\
Momento da alienação ou da prestação do serviço
\end{tabular}

\section{Consequentes:}

\begin{tabular}{l|ll} 
Critério pessoal & Sujeito ativo: & Estado unitário
\end{tabular}

${ }^{367}$ URUGUAY. Parlamento. Ley n. 17.296/2001, artículo 560.

${ }^{368}$ URUGUAY. Parlamento. Leys ns. 14.100/72, 16.736/96 e 18.719/2010. No Brasil não há previsão similar para nenhum tributo que alcança o consumo de bens ou serviços.

${ }^{369}$ Ao final do exercício, se remanescer saldo credor, caso provenha de diferença de alíquotas, integrará ao custo de vendas e não mais poderá ser transferido para a apuração seguinte, salvo exceções previstas na lei. Redação dada pela Ley n. 18.083/2006, artículo 17.

${ }^{370}$ MAZZ, Addy. ¿Estatuto del contribuyente o revision del Código Tributario y normas generales para su adecuacion a la normativa constitucional? Revista de la faculdad de Derecho de la Universidad de la Republica. Diciembre, 2008. p. 1-61. 


\begin{tabular}{|l|ll|}
\hline \multirow{3}{*}{ Critério quantitativo } & $\begin{array}{l}\text { Sujeito passivo: } \\
\text { Base de cálculo: }\end{array}$ & $\begin{array}{l}\text { Pessoas físicas e jurídicas que alienarem bens móveis e } \\
\text { imóveis e prestarem serviços } \\
\text { Alíquota: } \\
\text { Tributo a recolher: }\end{array}$ \\
& $\begin{array}{l}\text { Padrão: } 22 \% \text { - Alíquota reduzida: } 10 \% \\
\text { Tributo sujeito a não cumulatividade. }\end{array}$ \\
\hline
\end{tabular}

\section{Regra-matriz do IVA na importação de bens}

\begin{tabular}{|c|c|}
\hline \multicolumn{2}{|l|}{ Hipótese: } \\
\hline Critério material & Importar bens móveis do exterior; \\
\hline Critério espacial & Repartições alfandegárias \\
\hline Critério temporal & O momento do pagamento dos tributos aduaneiros \\
\hline
\end{tabular}

\section{Consequentes:}

\begin{tabular}{|c|c|c|}
\hline \multirow[t]{2}{*}{ Critério pessoal } & Sujeito ativo: & O Estado unitário \\
\hline & Sujeito passivo & Importador \\
\hline \multirow[t]{3}{*}{ Critério quantitativo } & Base de cálculo & $\begin{array}{l}\text { O preço que servir de base para o cálculo dos tributos } \\
\text { aduaneiros, acrescido do montante destes e exclusão do } \\
\text { próprio imposto. }\end{array}$ \\
\hline & Alíquota & Aquela prevista para as operações realizadas no país \\
\hline & Tributo a recolher & Devido no momento do pagamento dos tributos aduaneiros \\
\hline
\end{tabular}

\subsubsection{Imposto Específico Interno sobre o consumo (IMESI)}

O Impuesto Específico Interno ${ }^{371}$, de natureza monofásica e cumulativa, alcança a primeira alienação e a importação dos seguintes bens: bebidas alcoólicas e não alcoólicas; cosméticos e demais produtos de toucador; tabacos e cigarros; energia elétrica; veículos automotores; graxas e lubrificantes; combustíveis e outros derivados de petróleo; motores diesel; açúcar; equipamentos e artefatos de baixa eficiência energética.

Os contribuintes do imposto são os importadores dos bens elencados, quer sejam contribuintes habituais ou pessoas físicas que importem eventualmente, e as indústrias que promoverem a primeira comercialização das mercadorias abrangidas pela exação.

${ }^{371}$ URUGUAY. Parlamento. Ley n. 18.083, de 27/12/2006, artículos 33 a 36 e 38. 
O tributo não incide sobre as exportações, entretanto não há previsão de devolução dos valores eventualmente suportados nas aquisições de bens vinculados ao produto exportado.

A base de cálculo é formada pelo valor real da operação de alienação ou importação dos bens, entretanto poderá ser definida pelo poder executivo uma pauta fiscal de preços mínimos a serem observados pelo contribuinte, o que afronta o respeito à capacidade contributiva, já que o valor estimado pela potestade pode ser superior ao efetivamente praticado pelo contribuinte. Não há previsão de acerto entre a base estimada e o valor efetivamente praticado nas alienações ou importação de bens.

As alíquotas são diversas e sofrem variação progressiva, entre 4\% (açúcar) e 180\% (equipamentos de baixa eficiência energética e veículos). ${ }^{372}$

Parte da arrecadação desse tributo é afetada, ou seja, possui destinação específica declinada na lei instituidora, para pesquisa e combate do câncer, doenças cardiovasculares, bem como repartida com os governos departamentais.

Nesses termos, a regra matriz do imposto pode ser assim definida:

\section{Regra-matriz do (IMESI)}

\begin{tabular}{|l|l|}
\hline \multicolumn{2}{|l|}{ Hipótese: } \\
\hline $\begin{array}{l}\text { Critério material } \\
\text { Critério espacial }\end{array}$ & $\begin{array}{l}\text { Importar ou promover a primeira saída de produtos específicos } \\
\text { Âmbito territorial do Estado unitário } \\
\text { Critério temporal }\end{array}$ \\
\hline
\end{tabular}

\section{Consequentes:}

\begin{tabular}{|c|c|c|}
\hline \multirow[t]{2}{*}{ Critério pessoal } & Sujeito ativo: & O Estado unitário \\
\hline & Sujeito passivo: & Importadores e primeiros vendedores de produtos específicos \\
\hline \multirow[t]{3}{*}{ Critério quantitativo } & Base de cálculo: & $\begin{array}{l}\text { O valor da importação, acrescido dos tributos aduaneiros ou o } \\
\text { valor da primeira alienação do bem gravado. } \\
\text { Tributo sujeito a pauta fiscal }\end{array}$ \\
\hline & Alíquota: & Variável entre $4 \%$ a $180 \%$ \\
\hline & Tributo a recolher: & $\begin{array}{l}\text { Resultado da aplicação da alíquota sobre a base de cálculo. } \\
\text { Tributo cumulativo. }\end{array}$ \\
\hline
\end{tabular}

${ }^{372}$ A progressividade das alíquotas tem como base a essencialidade dos produtos, o objetivo de afastar o consumo de bens danosos à saúde, bem como o aumento da arrecadação. 


\subsection{Sistema tributário da República Bolivariana da Venezuela}

A Constitución de la República Bolivariana de Venezuela ${ }^{373}$ estabelece que o país é um Estado democrático social de direito, que adota o modelo federal, descentralizado política e administrativamente, sendo o território nacional dividido em estados ${ }^{374}$, Distrito Federal, dependências federais ${ }^{375}$ e municípios.

O sistema tributário da Venezuela é norteado pelos princípios da capacidade contributiva, da irretroatividade, da progressividade ${ }^{376}$ e da legalidade lit $^{377}$ e atribui o poder de tributar aos três níveis de governo: nacional, estadual e municipal. ${ }^{378}$

O texto constitucional consagra a proibição ao confisco ${ }^{379}$, a vedação de pagamento das obrigações fiscais mediante prestação de serviços pessoais ${ }^{380}$, submete a evasão fiscal à condenação civil e criminal $^{381}$ e estabelece que é dever do cidadão venezuelano suportar os gastos públicos mediante o pagamento de impostos, taxas e contribuições ${ }^{382}$ legalmente estabelecidos. $^{383}$

Apesar da opção pelo federalismo e as inúmeras previsões de compromisso de descentralização e autonomia a ser conferida aos estados, Distrito Federal e municípios ${ }^{384}$, o poder de tributar encontra-se fortemente concentrado no Poder Público Nacional (Nação), posto que é de sua competência a instituição e cobrança dos principais impostos (renda, sucessões, doações, capital, produção, valor agregado, combustíveis e minas, comércio exterior e demais impostos sobre o consumo), além de ser dotado de uma

373 VENEZUELA. Constitución de la República Bolivariana de Venezuela. Aprobada por el pueblo de Venezuela, mediante referendo constituyente, a los quince días del mes de diciembre de mil novecientos noventa y nueve, y proclamada por la Asamblea Nacional Constituyente en Caracas, a los veinte días del mes de diciembre de mil novecientos noventa y nueve. Artículos $2^{\circ}$ e $4^{\circ}$.

${ }^{374}$ Atualmente a nação é composta por vinte e dois estados.

${ }^{375}$ Conforme estabelece o artigo 17 da Constituição, as dependências federais são as ilhas marítimas não integradas no território de um estado, assim como as ilhas que se formem ou apareçam no mar territorial e não possuem autonomia de nenhuma natureza, inclusive fiscal.

${ }^{376}$ VENEZUELA. Constitución de la Repúblia Bolivariana de Venezuela, artículo 316.

377 VENEZUELA. Constitución de la Repúblia Bolivariana de Venezuela, artículo 317. A legalidade é exigida para a instituição, majoração e também para a concessão de isenções, reduções ou outras formas de incentivos fiscais.

${ }^{378}$ VENEZUELA. Constitución de la Repúblia Bolivariana de Venezuela, artículo 316.

${ }^{379}$ VENEZUELA. Constitución de la Repúblia Bolivariana de Venezuela, artículos 115, 116 y 316.

${ }^{380}$ VENEZUELA. Constitución de la Repúblia Bolivariana de Venezuela, artículo 316.

${ }^{381}$ VENEZUELA. Constitución de la Repúblia Bolivariana de Venezuela, artículo 316.

${ }^{382}$ A República venezuelana adota a teoria tripartite para identificar as espécies tributárias vigentes no país.

${ }^{383}$ VENEZUELA. Constitución de la Repúblia Bolivariana de Venezuela, artículo 133.

384 A descentralização é uma política nacional, deve aprofundar a democracia, aproximando o poder da população e criar as melhores condições para o exercício da democracia. Compete à Assembleia Nacional, por voto da maioria, atribuir aos municípios e aos estados determinadas matérias da competência nacional, a fim de promover a descentralização, conforme os artigos 157 e 158 da Constituição da Venezuela. 
competência residual para criar novas exações, desde que não pertencentes ao poder local previamente designado pela Constituição ou pelas leis nacionais já editadas. ${ }^{385}$

O cariz centralizador ${ }^{386}$ é reforçado pela competência atribuída à Nação para editar a legislação que irá garantir a coordenação e a harmonização das distintas potestades tributárias, definir princípios, parâmetros e limitações dos tipos impositivos (espécies tributárias) ou alíquotas dos tributos estaduais e municipais, assim como para criar fundos específicos que assegurem a solidariedade interterritorial ${ }^{387}$

Compete ainda ao poder central a instituição de impostos territoriais sobre prédios rurais e sobre transações imobiliárias, entretanto a fiscalização e a arrecadação deverão ser de responsabilidade dos municípios. ${ }^{388}$

Os estados são entidades autônomas, com personalidade jurídica plena ${ }^{389}$, responsáveis pela organização dos seus municípios e poderão instituir os impostos, taxas e contribuições especiais que a lei nacional autorizar. ${ }^{390}$

A repartição de receitas arrecadas pela Nação é estabelecida em norma infraconstitucional, entretanto há garantia de recebimento mínimo, conforme determina a lei orçamentária. ${ }^{391}$

Os municípios constituem a unidade política primária da organização nacional, com personalidade jurídica e relativa autonomia, limitada à eleição de suas autoridades, gestão das matérias de sua competência, instituição e arrecadação ${ }^{392}$ de taxas pelo uso de bens ou serviços públicos, de impostos sobre imóveis urbanos, veículos, espetáculos públicos, jogos e apostas lícitas, propaganda e publicidade comercial, sendo que a maior parte de sua

\footnotetext{
${ }^{385}$ VENEZUELA. Constitución de la Repúblia Bolivariana de Venezuela, artículo 156.

${ }^{386}$ VENEZUELA. Constitución de la Repúblia Bolivariana de Venezuela Além de definira as políticas fiscais da República, o poder nacional também controla as políticas financeiras e macroeconômicas, conforme estabelece o artigo 156, inciso 21 da Constituição da Venezuela.

${ }^{387}$ VENEZUELA. Constitución de la Repúblia Bolivariana de Venezuela, artículo 156, 13.

${ }^{388}$ VENEZUELA. Constitución de la Repúblia Bolivariana de Venezuela, artículo 156, 14.

${ }^{389}$ VENEZUELA. Constitución de la Repúblia Bolivariana de Venezuela, artículo 159.

${ }^{390}$ VENEZUELA. Constitución de la Repúblia Bolivariana de Venezuela, artículo 167.

391 “[...] una partida equivalente a un máximo del veinte por ciento del total de los ingresos ordinarios estimados anualmente por el Fisco Nacional, la cual se distribuirá entre los Estados y el Distrito Capital en la forma siguiente: un treinta por ciento de dicho porcentaje por partes iguales, y el setenta por ciento restante en proporción a la población de cada una de dichas entidades.En cada ejercicio fiscal, los Estados destinarán a la inversión un mínimo del cincuenta por ciento del monto que les corresponda por concepto de situado. A los Municipios de cada Estado les corresponderá, en cada ejercicio fiscal, una participación no menor del veinte por ciento del situado y de los demás ingresos ordinarios del respectivo Estado. La ley establecerá los principios, normas y procedimientos que propendan a garantizar el uso correcto y eficiente de los recursos provenientes del situado constitucional y de la participación municipal en el mismo." (VENEZUELA. Constitución de la Repúblia Bolivariana de Venezuela, artículo 167, 4).

${ }^{392}$ VENEZUELA. Constitución de la Repúblia Bolivariana de Venezuela, artículo 179.
} 
receita advém da repartição da receita dos tributos da Nação ou dos estados, conforme determina a legislação infraconstitucional.

A Asamblea Nacional é composta por deputados eleitos em cada entidade federal ${ }^{393}$ e compete a ela legislar sobre as matérias de competência nacional, discutir e aprovar o orçamento nacional e todo projeto de lei relacionado ao regime tributário. ${ }^{394}$

Os estados e municípios não podem criar aduanas nem impostos de importação, exportação e de trânsito sobre bens nacionais ou estrangeiros, ou sobre outras matérias de competência nacional, gravar bens de consumo antes de entrarem em circulação dentro do seu território, proibir o consumo de bens produzidos fora de seu território, nem gravá-los de forma diferente dos seus. ${ }^{395}$

O Código Tributário ${ }^{396}$ vigente foi recentemente remodelado e regula a obrigação tributária, inclusive os processos administrativos e judiciais fiscais, entretanto as normas relativas aos impostos sobre o consumo são esparsas e não se encontram codificadas.

Vigora na República Bolivariana da Venezuela um tributo geral sobre o consumo, incidente sobre o valor agregado (IVA) e diversos outros tributos sobre consumos específicos, tais como bebidas, cigarros e combustíveis.

\subsubsection{Imposto geral sobre o consumo - IVA}

O IVA é um imposto instituído e cobrado pelo poder nacional, plurifásico, não cumulativo, porque admite deduzir do valor a pagar o montante já cobrado nas etapas anteriores e que alcança todas as fases do ciclo econômico dos bens e serviços.

As hipóteses de incidência alcançam as alienações de bens móveis, as prestações de serviço em geral e a importação de bens móveis e prestações realizadas no exterior para serem utilizadas no país. ${ }^{397}$

Em relação ao comércio internacional, adota a tributação no país de destino, ao gravar com o ônus tributário as importações e tributa as exportações com alíquota zero, assegurada ao exportador a manutenção, utilização ou devolução do imposto incidente nas aquisições vinculadas aos produtos ou serviços exportados.

\footnotetext{
${ }^{393}$ VENEZUELA. Constitución de la Repúblia Bolivariana de Venezuela, artículo 186.

394 VENEZUELA. Constitución de la Repúblia Bolivariana de Venezuela, artículo 187.

395 VENEZUELA. Constitución de la Repúblia Bolivariana de Venezuela, artículo 183.

396 VENEZUELA. Asamblea Nacional. Código Orgánico Tributario. Gaceta Oficial n. 37.305 , de 17 de octubre de 2001.

${ }^{397}$ VENEZUELA. Presidencia de la República. Decretos Leyes ns. 5.189/2007 e 5.212/2007, artículos $1^{\text { y }}$ $3^{\circ}$.
} 
Os exportadores gozam de privilégio de poder aproveitar os créditos das aquisições relacionadas às exportações isentas e, na hipótese de acumulação, poderão utilizá-los para saldar outros tributos nacionais, pagamento de penalidades tributárias, custas processuais, solicitar a devolução em espécie ou autorização para a transferência do valor a terceiros interessados. $^{398}$

Os serviços de transporte internacional não gozam de isenção ou não incidência, e consideram-se parcialmente prestados no país, devendo ser aplicada a alíquota sobre o percentual de $50 \%$ do preço da passagem ou frete, para cada viagem que parta da Venezuela. $^{399}$

O contribuinte do imposto é aquele que realiza com habitualidade ou casualidade as hipóteses de incidência tributária, identificados na legislação como comerciantes, industriais, importadores e prestadores de serviços.

O fato gerador é considerado ocorrido na entrega dos bens ou no momento do registro da declaração aduaneira e, na prestação de serviços, quando da emissão da fatura. $\mathrm{Na}$ hipótese de exportação de bens móveis, na saída definitiva dos bens do território nacional (embora no momento a alíquota aplicável seja de $0 \%){ }^{400}$

Não se encontram sujeitas ao imposto as vendas de bens móveis intangíveis, tais como ações, bônus, cédulas hipotecárias, títulos e valores, conforme o artigo 16, as operações realizadas pelos bancos, operações de seguro etc.

Encontram-se isentas as importações de bens gravados com não incidência (princípio da não discriminação), importações efetuadas por agentes diplomáticos, produtos da cesta básica (arroz, pão, sal, ovos, açúcar, café, mortadela, sardinhas, leite, queijo, manteiga e margarina, carnes, azeites etc.), fertilizantes, medicamentos, combustíveis, livros e revistas, milho, minerais, soja, transporte de passageiros, terrestre e aquático, serviços médicos, odontológicos, entradas de espetáculos, fornecimento de água e gás, criação de gado. ${ }^{401}$

A base de cálculo do imposto, nas operações e prestações realizadas dentro do território nacional, corresponde ao valor do fato imponível, ou seja, o preço cobrado pela

\footnotetext{
${ }^{398}$ VENEZUELA. Presidencia de la República. Decretos Leys ns. 5.189/2007 y 5.212/2007, artículo 43.

${ }^{399}$ VENEZUELA. Presidencia de la República. Decretos Leys ns. 5.189/2007 y 5.212/2007, artículo 15.

${ }^{400}$ VENEZUELA. Presidencia de la República. Decretos Leys ns. 5.189/2007 y 5.212/2007, artículo 13.

${ }^{401}$ VENEZUELA. Presidencia de la República. Decretos Leys ns. 5.189/2007 y 5.212/2007, artículos 17 a 19.
} 
transação, não se admitindo a inclusão do próprio tributo em sua base de cálculo ${ }^{402}$. É, portanto, um tributo calculado "por fora" do preço.

Nas importações, a base de cálculo é formada pelo valor aduaneiro utilizado para a determinação dos tributos aduaneiros, acrescido destes, entretanto excluído o próprio IVA.

Em todos os casos deverão ser agregados à base de cálculo os ajustes, reajustes, fretes, seguro ou qualquer outra despesa cobrada do destinatário; da mesma forma, poderão ser deduzidas da base as reduções de preços, descontos, bonificações, independente de prévia condição (condicionado ao pagamento a vista ou volume de compras). ${ }^{403}$

A alíquota é fixada anualmente na Lei Orçamentária, entretanto a variação legalmente admitida é de $8 \%$ (oito por cento) a $16,5 \%$ (dezesseis e meio por cento). No exercício de 2014, a alíquota ficou estabelecida em 12\% (doze por cento), exceto para as exportações, renovada em $0 \%$ (zero por cento). ${ }^{404}$

A venda ou operações assimiladas e as importações de bens denominados suntuosos $^{405}$ estão sujeitos a uma alíquota adicional de $10 \%$ (dez por cento) no exercício de 2014, entretanto, conforme a reforma tributária que se encontra em curso na Venezuela, será elevada para alguns produtos para $15 \%$ (quinze por cento). Os bens são os seguintes: veículos de passeio com preço superior a 30 mil dólares, motocicletas de cilindrada superior a $500 \mathrm{~cm}^{3}$, máquinas de jogos ativadas com moedas ou fichas, helicópteros, aeronaves, caviar, touros, cavalos, joias com pedras preciosas com valor superior a 500 dólares. ${ }^{406}$

A não cumulatividade é ampla, admitindo-se deduzir do imposto a pagar o montante integral do imposto cobrado na aquisição ou importação de bens e serviços que correspondam aos custos, gastos ou egressos próprios da atividade econômica habitual do contribuinte, vinculados às operações e prestações tributadas (mesmo que seja aplicada a alíquota zero). Na hipótese de saídas isentas e não tributadas deverá ser feito o rateio do crédito proporcionalmente às saídas tributadas ${ }^{407}$. A parte desprezada não poderá ser transportada para os meses seguintes e deverá compor o custo do bem ou do serviço.

Entretanto, a norma estabelece que o crédito oriundo das aquisições constitui apenas um elemento técnico necessário para a determinação final do tributo a pagar, não gozando da natureza jurídica de crédito contra a República.

\footnotetext{
402 VENEZUELA. Presidencia de la República. Decretos Leyes ns. 5.189/2007 y 5.212/2007, artículo $23,4$. ${ }^{403}$ VENEZUELA. Presidencia de la República. Decretos Leyes ns. 5.189/2007 y 5.212/2007, artículo 24. ${ }^{404}$ VENEZUELA. Presidencia de la República. Decretos Leyes ns. 5.189/2007 y 5.212/2007, artículo 27. 405 VENEZUELA. Presidencia de la República. Decretos Leyes ns. 5.189/2007 y 5.212/2007, artículo 28. ${ }^{406}$ VENEZUELA. Presidencia de la República. Decretos Leyes ns. 5.189/2007 y 5.212/2007, artículo 61. ${ }^{407}$ VENEZUELA. Presidencia de la República. Decretos Leyes ns. 5.189/2007 y 5.212/2007, artículo 34.
} 
Apura-se o tributo devido mensalmente ${ }^{408}$, exceto na hipótese de importação, quando se deve recolher o IVA no momento do pagamento dos tributos devidos pela importação.

Na hipótese do saldo credor ser superior ao devedor, o contribuinte poderá trasladálor para os meses seguintes, até que seja deduzido integralmente. ${ }^{409}$

Pelo exposto, é possível extrair a seguinte regra-matriz do imposto:

\section{Regra-matriz do IVA}

\begin{tabular}{|l|l|}
\hline \multicolumn{2}{|l|}{ Hipótese: } \\
\hline Critério material & Alienar bens móveis e prestar serviços \\
Critério espacial & Âmbito territorial da Nação \\
Critério temporal & Momento da venda ou da prestação do serviço \\
\hline
\end{tabular}

\section{Consequentes:}

\begin{tabular}{l|ll} 
Critério pessoal & $\begin{array}{l}\text { Sujeito ativo: } \\
\text { Sujeito passivo: }\end{array}$ & $\begin{array}{l}\text { A Nação } \\
\text { Industriais, comerciantes e prestadores de serviços }\end{array}$ \\
Critério quantitativo & $\begin{array}{ll}\text { Base de cálculo: } \\
\text { Alíquota: }\end{array}$ & $\begin{array}{l}\text { O valor da operação de venda ou da prestação de serviços } \\
\text { Tributo a recolher: }\end{array}$ \\
& $\begin{array}{l}\text { Resultado do confronto de débitos - créditos apurados no mês. } \\
\text { Tributo sujeito a não cumulatividade. }\end{array}$
\end{tabular}

\section{Regra-matriz do IVA na importação de bens e serviços}

\section{Hipótese:}

\begin{tabular}{l|l} 
Critério material & Importar bens móveis do exterior; Importar serviços do exterior
\end{tabular}

Critério espacial Repartições alfandegárias

Critério temporal $\quad \mathrm{O}$ momento do pagamento dos tributos aduaneiros

\begin{tabular}{|l|ll|}
\hline \multicolumn{2}{|l|}{ Consequentes: } \\
\hline Critério pessoal & $\begin{array}{l}\text { Sujeito ativo: } \\
\text { Sujeito passivo }\end{array}$ & A Nação \\
Critério quantitativo & Base de cálculo & O preço que servir de base para o cálculo dos tributos \\
& & $\begin{array}{l}\text { aduaneiros, acrescido do montante destes e exclusão do } \\
\text { próprio imposto. }\end{array}$ \\
& & \\
\hline
\end{tabular}

${ }^{408}$ VENEZUELA. Presidencia de la República. Decretos Leyes ns. 5.189/2007 y 5.212/2007, artículo 32.

${ }^{409}$ VENEZUELA. Presidencia de la República. Decretos Leyes ns. 5.189/2007 y 5.212/2007, artículo 38. 


\begin{tabular}{|l|ll|}
\hline & $\begin{array}{l}\text { Alíquota } \\
\text { Tributo a recolher }\end{array}$ & $\begin{array}{l}\text { Aquela prevista para as operações internas da mercadoria } \\
\text { Devido no momento do pagamento dos tributos aduaneiros }\end{array}$ \\
\hline
\end{tabular}

\subsubsection{Impostos seletivos sobre o consumo}

Na República Bolivariana da Venezuela não há um único imposto seletivo sobre o consumo, mas diversas leis específicas que atribuem ao poder central o direito de instituir e cobrar, de forma monofásica e cumulativa, tributos sobre os seguintes bens e serviços: tabaco e cigarros ${ }^{410}$, bebidas alcoólicas ${ }^{411}$, gasolina e demais combustíveis derivados de petróleo $^{412}$, telecomunicações ${ }^{413}$, jogos de azar praticados em cassinos e salas de bingo ${ }^{414} \mathrm{e}$ os serviços prestados pelas empresas de turismo. ${ }^{415}$

No caso dos impostos, incidem na importação ou na primeira saída do fabricante nacional, sendo contribuintes os importadores, os industriais e os prestadores de serviços. Em todos os casos não incidem na exportação, entretanto inexiste na legislação tributária venezuelana a previsão de devolução aos exportadores do tributo incidente nas etapas antecedentes à exportação, como usualmente ocorre na tributação sobre o consumo.

A base de cálculo, nas operações realizadas dentro do território nacional, corresponde ao preço de venda na fábrica, $\mathrm{Na}$ importação, a base de cálculo será formada pelo valor aduaneiro, acrescida dos tributos devidos pela importação. A apuração do tributo é mensal.

Para uma futura harmonização tributária no Mercosul, esses impostos seletivos deverão contemplar os mesmos produtos eleitos por todos os Estados membros e, preferencialmente, honrar a plurifasia, e a não cumulatividade.

\section{Regra-matriz dos impostos seletivos}

\begin{tabular}{|l|l|}
\hline \multicolumn{2}{|l|}{ Hipótese: } \\
\hline Critério material & $\begin{array}{l}\text { Importar ou promover a primeira saída de produtos específicos } \\
\text { Armbito territorial da Nação }\end{array}$ \\
Critério espacial & $\begin{array}{l}\text { Aritério temporal } \\
\text { Momento da primeira venda ou da importação }\end{array}$ \\
\hline
\end{tabular}

${ }^{410}$ VENEZUELA. Presidencia de la República. Decreto Ley n. 5.619/2007.

${ }^{411}$ VENEZUELA. Presidencia de la República. Decreto Ley n. 5.618/2007.

412 VENEZUELA. Presidencia de la República. Ley Orgánica de Hidrocarburos/2006 y Ley Orgánica de Hidrocarburos Gaseosos (Decreto Ley n. 310/99).

${ }^{413}$ VENEZUELA. Presidencia de la República. Decreto Ley n. 2.189/2003.

${ }^{414}$ VENEZUELA. Presidencia de la República. Ley Organica de Telecomunicaciones. G.O n. 36.970/2000.

${ }^{415}$ Contribuição especial de $1 \%$ ao turismo cobrados dos prestadores de serviços turísticos sobre os ingressos brutos recebidos mensalmente, artigo 15 do Decreto da Ley Orgánica de Turismo. 


\section{Consequentes:}

Critério pessoal

Critério quantitativo
Sujeito ativo: $\quad$ O Estado Unitário

Sujeito passivo: Importadores e primeiros vendedores de produtos específicos

Base de cálculo: $\quad \mathrm{O}$ valor da importação, acrescido dos tributos aduaneiros ou o valor da primeira saída

Alíquota: $\quad$ Variável entre $0 \%$ a $70 \%$

Tributo a recolher: Resultado da aplicação da alíquota sobre a base de cálculo. Tributo cumulativo. 


\section{CAPÍTULO 5 - O SISTEMA TRIBUTÁRIO DA REPÚBLICA} FEDERATIVA DO BRASIL: REPARTIÇÃO DE COMPETÊNCIAS E AS ESPÉCIES TRIBUTÁRIAS QUE ALCANÇAM O CONSUMO DE BENS E SERVIÇOS

\subsection{A tributação do consumo sob a égide do federalismo brasileiro}

Vimos que as Constituições dos países membros do Mercosul pouca atenção deram ao domínio fiscal, limitando-se a elencar os princípios que regem o poder de tributar, transferindo à atividade legislativa infraconstitucional a responsabilidade de harmonizar o conjunto. Já a nossa mostrou-se pródiga ${ }^{416}$ e dispensou à matéria tributária fartas disposições, limitando, pelo menos em tese, o "labor e a criatividade do legislador ordinário". 417

A Constituição da República Federativa do Brasil de 1988 (CR/88) contém um extenso capítulo dedicado ao sistema tributário nacional, estruturado em três pilares: (i) o da repartição de competências tributárias entre a União, os Estados, o Distrito Federal e os Municípios; (ii) o dos princípios e das limitações constitucionais ao poder de tributar; (iii) o da repartição de receitas arrecadadas entre as pessoas políticas da federação. ${ }^{418}$

No tocante à repartição de competências, os entes da federação, inclusive os Municípios $^{419}$, possuem capacidade de instituir e cobrar tributos ${ }^{420}$, entretanto, além dos

\footnotetext{
${ }^{416}$ Sacha Calmon assim define o sistema tributário brasileiro: "O Brasil, ao contrário, inundou a Constituição com princípios e regras atinentes ao Direito Tributário. Somos, indubitavelmente, o país cuja Constituição é a mais extensa e minuciosa em tema de tributação. Este cariz, tão nosso, nos conduz a três importantes conclusões: os fundamentos do direito tributário brasileiro estão enraizados na Constituição, é texto fundante da ordem jurídico-tributária e as doutrinas forâneas devem ser recebidas com cautela, tendo em vista as diversidades constitucionais." (COÊLHO, Sacha Calmon Navarro. Curso de direito tributário brasileiro. Rio de Janeiro: Forense, 2005. p. 47-48).

${ }^{417}$ CARVALHO, Paulo de Barros. Curso de direito tributário. 26. ed. São Paulo: Saraiva, 2014. p. 156.

418 Sobre os três grupos temáticos, ver: COÊLHO, Sacha Calmon Navarro. Curso de direito tributário brasileiro. Rio de Janeiro: Forense, 2005. p. 48.

${ }^{419}$ A respeito da possibilidade de exercício de competências atribuída aos municípios, adotamos o seguinte posicionamento: "A Constituição Federal inclui, no pacto federativo, os municípios e o Distrito Federal, petrificando a fórmula de maneira inusitada, porquanto o federalismo, em sua formação clássica, envolve apenas a união dos Estados-Membros (federalismo dual). Entre nós, o município ostenta dignidade constitucional, mormente em matéria tributária." (COÊLHO, Sacha Calmon Navarro. Curso de direito tributário brasileiro. Rio de Janeiro: Forense, 2005. p. 62).

${ }^{420}$ Aliomar Baleeiro, sempre poético, cravou: "O tributo é vetusta e fiel sombra do poder político há mais de 20 séculos. Onde se ergue um governante, ela se projeta sobre o solo de sua dominação. Inúmeros testemunhos, desde a Antiguidade até hoje, excluem qualquer dúvida." (BALLEIRO, Aliomar. Limitações constitucionais ao poder de tributar. 7. ed. atualizada por Misabel Abreu Machado Derzi. Rio de Janeiro: Forense, 1997. p. 1). O nosso direito positivo estabelece que: "Tributo é toda prestação pecuniária compulsória, em moeda ou cujo valor nela se possa exprimir, que não constitua sanção de ato ilícito,
} 
contornos impostos pela Carta Magna, encontram-se todos adstritos às regras estruturais de suas leis complementares, que receberam o importante papel de traçar um arcabouço mínimo nacional, dirimir eventuais conflitos de competência entre os sujeitos ativos da obrigação tributária e estabelecer normas gerais em matéria de legislação fiscal. ${ }^{421}$

A Constituição faz referência a cinco espécies tributárias: (i) os impostos, (ii) as taxas, (iii) a contribuição de melhoria, (iv) os empréstimos compulsórios e (v) as contribuições especiais (sociais, profissionais e econômicas), embora não haja, na doutrina nacional, consenso em relação a essa divisão. ${ }^{422}$

É cediço que o Brasil não adotou um amplo tributo sobre o consumo de bens e serviços. No sistema constitucional tributário, norteado pelo federalismo, todos os entes políticos da federação possuem competência tributária para instituí-los e cobrá-los. Para alcançar os objetivos dessa tese, utilizaremos a seguinte classificação: ${ }^{423}$

a) À União compete a instituição (i) das contribuições sociais para os Programas de Integração Social e de Formação do Patrimônio do Servidor Público (PIS/PASEP) e para o Financiamento da Seguridade Social (COFINS) e (ii) do Imposto sobre Produtos Industrializados (IPI); $;^{424}$

instituída em lei e cobrada mediante atividade administrativa plenamente vinculada." (BRASIL. Código Tributário Nacional. 43. ed. São Paulo: Saraiva, 2014. Artigo $3^{\circ}$ ). Há vários autores nacionais que criticam essa denominação; podemos sugerir duas leituras a respeito: SCHOUERI, Luís Eduardo. Direito tributário. 3. ed. São Paulo: Saraiva, 2013. p. 137; e CARVALHO, Paulo de Barros, Curso de direito tributário, cit., p. 50 .

${ }^{421}$ BRASIL. Constituição (1988). Constituição da República Federativa do Brasil. Brasília, DF: Senado, 2014. Artigos 146 e 146-A.

${ }^{422}$ Schoueri elaborou um excelente resumo sobre as correntes que vigoram no Brasil, demonstrando que não há uniformidade quanto ao número de espécies e seus critérios de classificação. Há escolas que defendem a existência de apenas duas espécies de tributos: impostos e taxas (sustentada por Alberto Xavier, Alfredo Augusto Becker); outras, três: impostos, taxas, contribuições de melhoria (Paulo de Barros Carvalho, Aires Barreto, Roque Antonio Carraza e Sacha Calmon Navarro Coêlho); ou cinco: impostos, taxas, contribuições especiais, contribuição de melhoria e o empréstimo compulsório (Ives Gandra da Silva Martins, José Eduardo Soares de Melo e a jurisprudência do STF) ou ainda seis (impostos, taxas, contribuições de melhoria, empréstimos compulsórios, contribuições sociais e contribuições especiais), esta última adotada por Schoueri (SCHOUERI, Luís Eduardo. Direito tributário. 3. ed. São Paulo: Saraiva, 2013. p. 157).

${ }^{423}$ Há autores que não consideram as contribuições sociais PIS/PASEP e COFINS como tributos incidentes sobre o consumo, já que tributam a receita bruta e não a circulação de bens. Não obstante, os mesmos autores também reconhecem que essas contribuições possuem efeitos econômicos similares aos impostos sobre o consumo, razão pela qual as incluímos neste estudo. Não há como falar em harmonização tributária das legislações tributárias dos países do Mercosul sem levar em conta essa espécie tributária. Em sentido contrário à nossa proposição e, por fazer referência completa às correntes doutrinárias que vigoram no país, recomenda-se: MACEDO, José Alberto Oliveira. Conflitos de competência na tributação do consumo. 2013. 161 f. Tese (Doutorado em Direito Econômico, Financeiro e Tributário) - Faculdade de Direito da Universidade de São Paulo, São Paulo, 2013.

${ }^{424}$ Não há dúvida que o Imposto sobre operações de crédito, câmbio, seguro e sobre operações relativas a títulos e valores mobiliários (Imposto sobre operações financeiras - IOF) e a contribuição de intervenção no domínio econômico - CIDE, são impostos sobre o consumo, por alcançarem a renda dispendida, entretanto, não se amoldam ao projeto de harmonização fiscal proposta nessa tese. Deverão fazer parte do 
b) Aos Estados e ao Distrito Federal, o Imposto sobre a Circulação de Mercadorias e Serviços de Transporte e Comunicação (ICMS);

c) Aos Municípios e ao Distrito Federal, o Imposto sobre Serviços de Qualquer Natureza (ISSQN).

No segundo grupo temático, que compreende os princípios constitucionais tributários e as limitações ao poder de tributar, o constituinte originário cuidou de fortalecer o capítulo específico da tributação, mediante o desdobramento dos direitos e garantias individuais, consagrando-os ora em princípios, ora em imunidades ${ }^{425}$. E assim o fez, como nos ensina Derzi, porque, ao fundar a República em Estado Democrático de Direito, erigiu um "sistema tributário norteado pelo reforço ao federalismo e dirigido pela igualdade, capacidade contributiva, segurança e certeza do direito". 426

O terceiro pilar, que cuida da repartição das receitas, objetiva redistribuir o resultado das exações entre os entes da federação e elegeu a forma direta (privilegiando o local de origem da receita) e a indireta (por meio da constituição de fundos de participação ou programas de financiamento geridos pela legislação infraconstitucional) para fazê-lo. Cumpre lembrar que apenas os impostos são objeto da partilha, tendo como única exceção a Contribuição de Intervenção no Domínio Econômico (CIDE) ${ }^{427}$, fato que enseja constante reclame dos Estados e dos Municípios, que se sentem, com razão, prejudicados pela não participação em outras receitas. ${ }^{428}$

Nessa toada, as espécies tributárias que alcançam o consumo no Brasil serão analisadas conforme o seu desenho normativo, tornando possível o conhecimento do liame jurídico estabelecido para cada uma delas.

\subsection{O Imposto sobre Produtos Industrializados (IPI)}

rol dos tributos extintos, na hipótese de implementação de um tributo geral sobre o consumo, ou sofrerem as adaptações necessárias para serem tratados como tributos seletivos sobre o consumo.

425 BALLEIRO, Aliomar. Limitações constitucionais ao poder de tributar. 7. ed. atualizada por Misabel Abreu Machado Derzi. Rio de Janeiro: Forense, 1997. p. 14.

${ }^{426}$ BALLEIRO, Aliomar. Limitações constitucionais ao poder de tributar. 7. ed. atualizada por Misabel Abreu Machado Derzi. Rio de Janeiro: Forense, 1997. p. 3.

${ }^{427}$ A Emenda Constitucional n. 44/2004 estabeleceu a divisão da CIDE relativa às atividades de importação ou comercialização de petróleo e seus derivados, gás natural, seus derivados e álcool combustível.

${ }^{428}$ Como exemplo: a arrecadação das contribuições para o PIS e para a COFINS. 
O IPI é um imposto de competência da União, regido pelos princípios da seletividade $^{429}$ e da não cumulatividade ${ }^{430}$, previsto no artigo 153 , IV, da Constituição Federal e disciplinado pelos artigos 46 a 51 do Código Tributário Nacional (CTN).

A hipótese de incidência alcança os produtos industrializados na circunstância do desembaraço aduaneiro, no caso de importação, e no momento da saída dos estabelecimentos industriais/importadores ou na sua arrematação, quando apreendidos ou abandonados e levados a leilão.

O conceito de industrialização é abrangente e engloba qualquer operação que modifique a natureza ou a finalidade do produto, ou o aperfeiçoe para o consumo. ${ }^{431}$

O imposto não alcança a exportação de produtos destinados ao exterior ${ }^{432}$, os livros, jornais, periódicos destinados à sua impressão ${ }^{433}$, o ouro, quando definido como ativo financeiro $^{434}$ ou instrumento cambial e o fornecimento de energia elétrica, derivados de petróleo, combustíveis e minerais do país. ${ }^{435}$

Em relação aos produtos industrializados exportados, o contribuinte poderá manter e utilizar os créditos das aquisições relacionadas aos bens imunes, respeitando regra mundial da tributação do consumo. ${ }^{436}$

O contribuinte do imposto é o importador, o industrial e o arrematante ${ }^{437}$. São raros os casos de sujeição passiva por substituição tributária para as operações anteriores, concomitantes ou posteriores às saídas promovidas pelo contribuinte.

A base de cálculo do imposto é assim definida, por hipótese de incidência: (i) na importação: o preço que servir de base para os tributos aduaneiros, acrescido do imposto sobre a importação, das taxas exigidas para a entrada do produto no país e dos encargos

${ }^{429}$ BRASIL. Constituição (1988). Constituição da República Federativa do Brasil. Brasília, DF: Senado, 2014. O artigo 153, parágrafo $3^{\circ}$, I, estabelece que o imposto "será seletivo, em função da essencialidade do produto".

${ }^{430}$ BRASIL. Constituição (1988). Constituição da República Federativa do Brasil. Brasília, DF: Senado, 2014. O artigo 153, parágrafo $3^{\circ}$, II, estabelece que o imposto "será não cumulativo, compensando-se o que for devido em cada operação com o montante cobrados nas anteriores".

${ }^{431}$ BRASIL. Código Tributário Nacional. 43. ed. São Paulo: Saraiva, 2014. Artigo 46, parágrafo único.

432 BRASIL. Constituição (1988). Constituição da República Federativa do Brasil. Brasília, DF: Senado, 2014. Conforme prevê o artigo 153, parágrafo $3^{\circ}$, III.

433 BRASIL. Constituição (1988). Constituição da República Federativa do Brasil. Brasília, DF: Senado, 2014. Conforme previsto no artigo 150, VI, alínea "d".

434 BRASIL. Constituição (1988). Constituição da República Federativa do Brasil. Brasília, DF: Senado, 2014. Artigo $153, \S 5^{\circ}$.

435 BRASIL. Constituição (1988). Constituição da República Federativa do Brasil. Brasília, DF: Senado, 2014, art. $155, \S 3^{\circ}$.

436 "Para que a imunidade seja plena, impõem-se a manutenção e o aproveitamento dos créditos acumulados nas operações anteriores." (COÊLHO, Sacha Calmon Navarro. Curso de direito tributário brasileiro. Rio de Janeiro: Forense, 2005. p. 365).

${ }^{437}$ BRASIL. Código Tributário Nacional. 43. ed. São Paulo: Saraiva, 2014. Artigo 51. 
cambiais efetivamente pagos pelo importador ou dele exigíveis; (ii) na comercialização: o valor da operação que decorrer a saída da mercadoria; e, c) na arrematação: o preço da arrematação.

Note-se que o imposto é calculado por fora, ou seja, não compõe a base de cálculo do próprio tributo, como ocorre com o ICMS, PIS/COFINS e ISSQN. Entretanto, acaba por incidir sobre eles, quando existentes, já que ingressaram no preço do produto, em clara majoração do critério quantitativo da norma tributária.

Para a aplicação da alíquota, deve ser observada a Tabela de Incidência do IPI (TIPI), que contém todos os produtos devidamente catalogados, distribuídos por seções, capítulos, posições, itens e subitens, classificados de acordo com as regras gerais para interpretação da Nomenclatura Comum do Mercosul (NCM). Dessa forma, o imposto é calculado mediante a aplicação das alíquotas constantes da TIPI sobre o valor tributável dos produtos (base de cálculo).

O IPI pode ter as suas alíquotas alteradas por ato administrativo, sob condições e limites fixados em lei, o que representa uma rara exceção ao princípio constitucional da legalidade ${ }^{438}$. Entretanto, devem ser eleitas na razão inversa à essencialidade dos produtos. $^{439}$

Como o imposto pode incidir em mais de uma fase no circuito econômico, a não cumulatividade prevista no texto constitucional é plena ${ }^{440}$ e não comporta nenhuma restrição em relação à sua universalidade. Não obstante, a legislação ordinária é restritiva e reconhece apenas os créditos das matérias primas, dos produtos intermediários e do material de embalagem (insumos), bem como o valor do imposto pago na importação. ${ }^{441}$

\footnotetext{
${ }^{438}$ Trata-se de uma exceção ao princípio da legalidade, bastante criticada pela doutrina. Por todos: COÊLHO, Sacha Calmon Navarro. Curso de direito tributário brasileiro. Rio de Janeiro: Forense, 2005. p. 366.

${ }^{439}$ TORRES, Ricardo Lobo. Curso de direito financeiro e tributário. 10. ed. atual. Rio de Janeiro: Renovar, 1993. p. 312. O autor defende que "a seletividade, colocada como princípio constitucional é um dos subprincípios da capacidade contributiva, a significar que o tributo deve incidir progressivamente na razão inversa da essencialidade dos produtos: quanto menor a utilidade do produto tanto maior deverá ser a alíquota e vice-versa."

440 "[...] o crédito a apropriar envolve o que decorrer da aquisição de bens do ativo fixo e de bens de uso e consumo." (COÊLHO, Sacha Calmon Navarro. Curso de direito tributário brasileiro. Rio de Janeiro: Forense, 2005. p. 365).

${ }^{441}$ BRASIL. Decreto n. 7.212, de 15 de junho de 2010. Regulamenta a cobrança, fiscalização, arrecadação e administração do Imposto sobre Produtos Industrializados - IPI. Artigo 226. Disponível em: <http: ॥www.planalto.gov.br>. Acesso em: 05 ago. 2014. Em 13.08.2012 foi publicada a Súmula n. 495 do STJ sobre o tema, estabelecendo o seguinte: "A aquisição de bens integrantes do ativo permanente da empresa não gera direito a creditamento de IPI'. Não obstante, cumpre lembrar que os precedentes analisados eram anteriores à Emenda Constitucional n. 42/2003, que alterou substancialmente o princípio da não cumulatividade do IPI. Ver, a esse respeito: ANDRADE FILHO, Edmar Oliveira. Créditos do IPI $e$ $o$ ativo permanente. Disponível em: <http://cfc.jusbrasil.com.br/noticias/100060570/creditos-do-ipi-e-oativo-permanente>. Acesso em: 08 ago. 2014.
} 
Se do confronto entre débitos e créditos resultar saldo credor a favor do contribuinte, ele será transferido para o período seguinte e, na hipótese de acumulação, inclusive em razão de exportações, poderá ser utilizado para a compensação de outros tributos federais, conforme normas expedidas pela Receita Federal do Brasil, ou serão objeto de pedido de ressarcimento, nos termos da legislação ordinária. ${ }^{442}$

O período de apuração do imposto é mensal e o prazo para o seu recolhimento, nas operações realizadas no país, é o vigésimo quinto dia do mês subsequente à apuração e, nas operações de importação, antes da saída do produto da repartição que processar o despacho aduaneiro.

As microempresas e as empresas de pequeno porte optantes pelo regime do Simples Nacional $^{443}$ ficam vedadas de apropriar e transferir créditos relativos ao imposto, em claro obstáculo ao princípio da não cumulatividade, consagrado constitucionalmente.

Por fim, o texto constitucional obriga que o legislador ordinário reduza o seu impacto sobre a aquisição de bens de capital pelo contribuinte do imposto, de modo a fomentar a permanente renovação dos bens que compõem o parque industrial da nação.

Assim, podemos construir a regra-matriz do IPI, da seguinte forma:

\section{Regra-matriz de incidência do IPI no mercado interno}

\section{Hipótese:}

Critério material

Industrializar produtos ou circular produtos importados

Critério espacial

Qualquer lugar no território nacional

Critério temporal

O momento da saída do produto do estabelecimento industrial

\section{Consequentes:}

Critério pessoal

Sujeito ativo: A união

Sujeito passivo: $\quad$ O industrial, o importador ou o arrematante

Critério quantitativo

Base de cálculo: $\quad$ o preço da operação na saída do produto

Alíquota:

Variável e seletiva conforme tabela de incidência (TIPI)

Tributo a recolher: Resultado do confronto de débitos-créditos apurados no mês.

Tributo sujeito à não cumulatividade

${ }^{442}$ BRASIL. Decreto n. 7.212, de 15 de junho de 2010. Regulamenta a cobrança, fiscalização, arrecadação e administração do Imposto sobre Produtos Industrializados - IPI. Artigos 256 e 257. Disponível em: <http: Ilwww.planalto.gov.br>. Acesso em: 05 ago. 2014.

443 BRASIL. Lei Complementar n. 123, de 14 de dezembro de 2006. Institui o Estatuto Nacional da Microempresa e da Empresa de Pequeno Porte. Artigo 226. Disponível em: 〈http:Ilwww.planalto.gov.br>. Acesso em: 05 ago. 2014. 
Regra-matriz de incidência do IPI na importação de produtos:

\begin{tabular}{|l|l|}
\hline \multicolumn{2}{|l|}{ Hipótese: } \\
\hline Critério material & Importar produtos \\
Critério espacial & Repartições alfandegárias \\
Critério temporal & O momento do desembaraço aduaneiro \\
\hline
\end{tabular}

\section{Consequentes:}

\begin{tabular}{|l|ll}
\hline Critério pessoal & $\begin{array}{l}\text { Sujeito ativo: } \\
\text { Critério quantitativo }\end{array}$ & $\begin{array}{l}\text { A união } \\
\text { Base de cálculo: }\end{array}$ \\
& $\begin{array}{l}\text { O importador } \\
\text { Oduaneiros, acrescido que servir de base para o cálculo dos tributos } \\
\text { Alíquota: } \\
\text { cambiais devidos pelo importador }\end{array}$ \\
& $\begin{array}{l}\text { Variável e seletiva conforme tabela de incidência (TIPI) } \\
\text { Tributo a recolher: }\end{array}$ & Devido no momento do desembaraço aduaneiro \\
\hline
\end{tabular}

\subsection{As Contribuições PIS/PASEP e COFINS}

A Constituição Republicana estabeleceu que a seguridade social, assim compreendida como o conjunto integrado de ações de iniciativa dos poderes públicos e da sociedade, destina-se a assegurar os direitos relativos à saúde, à previdência e à assistência social de todos os brasileiros.

Para assegurar os seus objetivos e concretizar os direitos e garantias fundamentais do cidadão previstos no artigo $5^{\circ}$ da Carta Magna, a seguridade social é financiada pelos recursos provenientes dos entes da federação e, principalmente, pelas contribuições (ditas sociais) que incidem sobre: (i) a folha de salários, a receita ou o faturamento e o lucro do empregador e da empresa; (ii) do trabalhador e demais segurados da previdência; (iii) a receita de concursos de prognósticos; (iv) o importador de bens ou serviços do exterior.

As contribuições PIS/PASEP ${ }^{444}$ e COFINS se inserem nesse contexto, variando conforme sejam seus contribuintes pessoas jurídicas de direito privado, público ou contribuintes especiais, alcançando:

\footnotetext{
${ }^{444}$ A contribuição social que incide sobre o faturamento, nos precisos termos do artigo 195 da Constituição Federal, é a COFINS, se considerarmos, como bem sustenta Soares de Melo, que o PIS/PASEP fundamenta-se no artigo 239 (apesar de ser fonte de custeio da seguridade social). Didaticamente, e compreendendo a realidade de sua incidência, sempre em conjunto com a primeira e contendo raras diferenças estruturais, optamos por enquadrá-lo aqui (MELO, José Eduardo Soares de. Contribuições sociais no sistema tributário. 4. ed. rev., atual. e ampl. São Paulo: Malheiros, 2003).
} 
a) o faturamento ou o auferimento de receitas, para pessoas jurídicas de direito privado;

b) o pagamento da folha de salários, para entidades de relevância social determinadas em lei,

c) a arrecadação mensal de receitas correntes e o recebimento mensal de recursos, para entidades de direito público.

Considerados os objetivos desta tese, serão delineados os aspectos da hipótese prevista na alínea "a".

O PIS e a COFINS são, portanto, contribuições sociais cobradas pela União, destinadas à seguridade social, embora a receita não seja destinada a esse fim, razão do descontentamento de grande parte da doutrina nacional, que rechaçou esses tributos. ${ }^{445}$

Há imunidade para as receitas decorrentes de exportação, bem como a manutenção dos créditos tomados relacionados à remessa ao exterior (art.149, § 2º I, da CR/88).

Para apurar o tributo, convivem dois regimes, a saber: o regime de incidência cumulativa $^{446}$ alcança as pessoas jurídicas de direito privado que apuram o Imposto de Renda (IRPJ) com base no lucro presumido ou arbitrado. O regime de incidência não cumulativa $^{447}$ alcança as pessoas jurídicas de direito privado que apuram o IRPJ com base no lucro real, com algumas exceções estabelecidas na legislação ordinária.

No regime cumulativo, a base de cálculo é o total das receitas da pessoa jurídica, não se admitindo a dedução do tributo incidente na aquisição de bens e serviços utilizados como custos, despesas e outros encargos. As alíquotas a serem aplicadas são: 0,65\% para o PIS e $3 \%$ para a COFINS.

Para o regime não cumulativo, a base de cálculo é o total das receitas da pessoa jurídica, descontados os créditos apurados com base nos custos, despesas e encargos. As alíquotas são: $1,65 \%$ PIS e 7,6\% para a COFINS.

\footnotetext{
445 Por todos, Torres: “[...] montou-se um perverso sistema de impostos com destinação especial, distorcendo-se inteiramente a natureza e a finalidade das contribuições sociais. [...] Algumas causas explicam a anomalia: a) transferia-se a responsabilidade pelo pagamento do tributo para o empresariado ou para a sociedade em geral, retirando dos ombros dos beneficiários da seguridade social o ônus financeiro da tributação e tornando-a invisível; b) ladeava-se a obrigação constitucional do repasse do produto da arrecadação aos Estados e Municípios, pois a União se apossava da totalidade dos recursos." (TORRES, Ricardo Lobo. É possível a criação do IVA no Brasil? In: SARAIVA FILHO, Oswaldo Othon de Pontes; VASQUES, Sérgio; GUIMARÃES, Vasco Branco (Org.). IVA para o Brasil: contributos para a reforma da tributação do consumo. Belo Horizonte: Fórum, 2007. p. 25).

${ }^{446} \mathrm{O}$ texto constitucional estabeleceu que a adoção ou não da regra da não cumulatividade deveria ser estabelecida pela legislação, razão pela qual convivem os dois modelos.

447 Esse regime foi instituído em dezembro de 2002 (PIS/PASEP) e fevereiro de 2004 (COFINS). As legislações vigentes são, respectivamente, Leis ns. 10.637/2002 e 10.833/2003.
} 
Após a apuração do tributo, o saldo eventualmente credor será transferido para o período seguinte. Havendo acumulação, inclusive em razão de exportações, poderá ser utilizado para a compensação de outros tributos federais, conforme normas expedidas pela Receita Federal do Brasil ou será objeto de pedido de ressarcimento, nos termos da legislação ordinária.

Para o modelo não cumulativo, entendemos que deveria ter sido adotado o conceito amplo de créditos, sem restrições, de modo a tornar a exação livre da tributação em cascata, sob o ponto de vista econômico. Entretanto, há várias restrições ao reconhecimento dos créditos das aquisições de insumos utilizados pelos industriais, maculando-o com os defeitos gerados pela incompreensão da necessária neutralidade que os tributos sobre o consumo exigem. ${ }^{448}$

As microempresas e as empresas de pequeno porte optantes pelo regime do Simples Nacional ficam vedadas de apropriar créditos nas suas aquisições, mas aqueles que adquirem bens ou serviços deles podem reconhecê-los integralmente, desde que se enquadrem no regime da não cumulatividade.

O período de apuração do imposto é mensal e o prazo para o seu recolhimento, nas operações realizadas no país, é, via de regra, o vigésimo quinto dia do mês subsequente à apuração. Nas operações de importação, o pagamento deve ocorrer no momento do desembaraço aduaneiro.

Por último, convém lembrar que o tributo é calculado por dentro do valor considerado como faturamento, ou seja, incide sobre si mesmo e também sobre o IPI, o ICMS e o ISSQN, quando incidentes na operação ou na prestação que ensejar o faturamento. As discussões judiciais a esse respeito estão bastante adiantadas e os contribuintes saíram vitoriosos na exclusão do ICMS e das próprias contribuições no cálculo do tributo, nas hipóteses de importação. ${ }^{449}$

Dessa forma, podemos construir a seguinte regra-matriz:

\footnotetext{
${ }^{448}$ Discute-se no Supremo Tribunal Federal o alcance da não cumulatividade para o PIS e a COFINS. BRASIL. Supremo Tribunal Federal. Repercussão Geral. Recurso Extraordinário RE n. 592616. Relator Ministro Celso de Mello. Boletim de Jurisprudência Tributária, Belo Horizonte, Lexlegis, v. 1, p. 72-95, mar. 2014.

${ }^{449}$ BRASIL. Supremo Tribunal Federal. Repercussão Geral. Recurso Extraordinário RE n. 559937. Relator Ministra Ellen Gracie. Trânsito em julgado em 24/10/2014. Boletim de Jurisprudência Tributária, Belo Horizonte, Lexlegis, v. 5, p. 1-5, out. 2014. A respeito da exclusão do ISSQN, ver: BRASIL. Supremo Tribunal Federal. Repercussão Geral. Recurso Extraordinário RE n. 592616. Relator Ministro Celso de Mello. Boletim de Jurisprudência Tributária, Belo Horizonte, Lexlegis, v. 1, p. 72-95, mar. 2014. A respeito da exclusão do ICMS, ver: BRASIL. Supremo Tribunal Federal. Repercussão Geral. Recurso Extraordinário RE n. 574706. Relatora Ministra Cármen Lúcia. Boletim de Jurisprudência Tributária, Belo Horizonte, Lexlegis, v. 1, p. 241-260, mar. 2014.
} 
Regra-matriz de incidência do PIS/COFINS no mercado interno

\begin{tabular}{|l|l|}
\hline \multicolumn{2}{|l|}{ Hipótese: } \\
\hline Critério material & Auferir receita pela pessoa jurídica \\
Critério espacial & Qualquer lugar no território nacional \\
Critério temporal & O momento do auferimento da receita \\
\hline
\end{tabular}

\begin{tabular}{|c|c|c|}
\hline \multicolumn{3}{|l|}{ Consequentes: } \\
\hline \multirow[t]{2}{*}{ Critério pessoal } & Sujeito ativo: & A união \\
\hline & Sujeito passivo: & Pessoa jurídica que auferir receita \\
\hline \multirow[t]{5}{*}{ Critério quantitativo } & Base de cálculo: & O valor total das receitas auferidas pela pessoa jurídica \\
\hline & Alíquota: & Regime cumulativo: $0,65 \%$ (PIS) e $3 \%$ (COFINS); \\
\hline & & Regime não cumulativo: 1,65\% (PIS) 7,6\% (COFINS) \\
\hline & Tributo a recolher: & $\begin{array}{l}\text { Regime cumulativo: o resultado da alíquota sobre a base de } \\
\text { cálculo; }\end{array}$ \\
\hline & & $\begin{array}{l}\text { Regime não cumulativo: o resultado da alíquota sobre a base } \\
\text { de cálculo, deduzidos os créditos calculados sobre as despesas } \\
\text { previstas em lei }\end{array}$ \\
\hline
\end{tabular}

\section{Regra-matriz de incidência do PIS/COFINS na importação de produtos}

\begin{tabular}{|l|l|}
\hline \multicolumn{2}{|l|}{ Hipótese: } \\
\hline Critério material & Importar bens e contratar serviços do exterior cujo resultado seja verificável no país \\
Critério espacial & Repartições alfandegárias \\
Critério temporal & O momento do desembaraço aduaneiro \\
\hline
\end{tabular}

\section{Consequentes:}

\begin{tabular}{|l|ll|}
\hline Critério pessoal & $\begin{array}{l}\text { Sujeito ativo: } \\
\text { Sujeito passivo: }\end{array}$ & $\begin{array}{l}\text { A união } \\
\text { O importador do bem ou do serviço }\end{array}$ \\
& $\begin{array}{ll}\text { Base de cálculo: } & \text { O preço que servir de base para o cálculo dos tributos } \\
\text { aduaneiros, acrescido do montante destes e dos encargos } \\
\text { cambiais devidos pelo importador }\end{array}$ \\
$\begin{array}{ll}\text { Alíquota: } \\
\text { Tributo a recolher: }\end{array}$ & $\begin{array}{l}\text { A alíquota padrão para o PIS é 1,65\% e para a COFINS } 7,6 \% \\
\text { serviço momento do desembaraço aduaneiro do bem ou do }\end{array}$ \\
& \\
\end{tabular}




\subsection{O ICMS dos Estados e do Distrito Federal}

Compete aos Estados e ao Distrito Federal instituir o ICMS, nos termos do artigo 155, inciso II da Constituição Federal de 1988, orientado pelos princípios da seletividade ${ }^{450}$, da não cumulatividade ${ }^{451}$ e regido nacionalmente pela Lei Complementar $\mathrm{n}$. $87 / 96 .^{452}$

A primeira hipótese de incidência alcança as operações relativas à circulação de mercadorias ${ }^{453}$ realizadas no país, inclusive a importação promovida por pessoas físicas ou jurídicas $^{454}$, ainda que não sejam contribuintes habituais do imposto, como bem orienta a tributação mundial sobre o consumo. ${ }^{455}$

O imposto considera-se devido no território onde se encontrar a mercadoria no momento da ocorrência do fato gerador, exceto na importação, que deverá ser recolhido para o Estado onde estiver localizado o importador, embora a Lei Complementar n. 87/96 estabeleça que o recolhimento deva ser direcionado para o Estado onde ocorrer a entrada

${ }^{450}$ Diferente do que estabelece para o IPI, o texto constitucional dispõe que o ICMS "poderá" ser seletivo em função da essencialidade das mercadorias e serviços. Filiamo-nos à corrente que considera a seletividade como um princípio garantidor da isonomia, da igualdade, da capacidade contributiva, conforme Ricardo Lobo Torres, Misabel Derzi e Paulo de Barros Carvalho.

${ }^{451}$ A não cumulatividade no ICMS admite duas exceções: quando a saída da mercadoria ou a prestação de serviços for isenta ou gravada pela não incidência, haverá cumulação, vez que os créditos relativos às operações anteriores deverão ser anulados. Quando se exporta, é assegurada ao exportador, ao contrário da regra geral, a manutenção dos créditos. É bom lembrar que a legislação dos Estados também poderá assegurar esse direito, em sua lei ordinária, instituidora do tributo. (BRASIL. Constituição (1988). Constituição da República Federativa do Brasil. Brasília, DF: Senado, 2014. Artigo 155, § 20, II, “b”). Entendemos que Constituição positivou as duas únicas hipóteses em que o princípio da não cumulatividade poderia ser afastado pelo legislador ordinário.

${ }^{452}$ BRASIL. Lei Complementar n. 87, de 13 de setembro de 1996. Dispõe sobre o imposto dos Estados e do Distrito Federal sobre operações relativas à circulação de mercadorias e sobre prestações de serviços de transporte interestadual e intermunicipal e de comunicação, e dá outras providências. (Lei Kandir). Disponível em: <http://www.planalto.gov.br/ccivil_03/leis/lcp/lcp87.htm>. Acesso em: 05 ago. 2014.

${ }^{453}$ Registre-se que: “[...] tal circulação só pode ser jurídica (e, não, meramente física). A circulação jurídica pressupõe a transferência (de uma pessoa para outra) da posse ou da propriedade da mercadoria. Sem mudança de titularidade da mercadoria não há que falar em tributação por meio de ICMS. Esta ideia, abonada pela melhor doutrina (Souto Maior Borges, Geraldo Ataliba, Paulo de Barros Carvalho, Cléber Giardino etc.), encontrou ressonância no próprio Supremo Tribunal Federal." (CARRAZZA, Roque Antônio. ICMS. 9. ed., rev. e ampl. de acordo com a Lei Complementar 87/96 e suas ulteriores modificações. São Paulo: Malheiros, 2002. p. 36). O Superior Tribunal de Justiça também acolheu essa tese e publicou a Súmula n. 166, que assim dispõe: "Fato Gerador - ICMS - Deslocamento de Mercadoria Estabelecimento do Mesmo Contribuinte. Não constitui fato gerador do ICMS o simples deslocamento de mercadoria de um para outro estabelecimento do mesmo contribuinte."

${ }^{454}$ COÊLHO, Sacha Calmon Navarro. Curso de direito tributário brasileiro. Rio de Janeiro: Forense, 2005. p. 391.

${ }^{455}$ Não há razões para se defender a não tributação das importações, quer seja ela realizada por pessoa física ou jurídica, sob o risco de descumprimento dos tratados internacionais assinados pelo país, tal como o GATT/OMC e aniquilamento da indústria nacional. Concordamos com o posicionamento de Coêlho: "O constituinte de 88 , por delegação do povo, suplantou o julgado que dispunha de modo contrário. A LC 87/96 adotou o princípio geral de todos os impostos sobre valores adicionados: (a) tributar todas as importações e (b) não tributar as exportações." (COÊLHO, Sacha Calmon Navarro. Curso de direito tributário brasileiro. Rio de Janeiro: Forense, 2005. p. 413). 
física do bem ou onde estiver domiciliado o adquirente, quando não estabelecido. Por óbvio, em razão dessa discrepância, há situações em que a mercadoria ingressa em local distinto do estabelecimento que promove a importação, gerando um conflito de competências entre unidades federativas e dupla exigência do tributo. ${ }^{456}$

A segunda alcança as prestações de serviços de comunicação e a última as prestações de serviço de transporte interestaduais ou intermunicipais, já que o transporte realizado no âmbito do município se sujeita ao ISSQN.

Nesses casos, o imposto considera-se devido onde tenha iniciado a prestação de serviço de transporte e, para as prestações de serviço de comunicação, o da prestação, assim entendido como o local da geração, emissão, transmissão repetição, ampliação ou recepção do serviço, sem prejuízo do recolhimento do ICMS complementar devido no destino, conforme será analisado no tópico relacionado às alíquotas do imposto.

Embora o aspecto material esteja bem delineado no próprio nome do tributo, há previsão expressa no texto constitucional $^{457}$ para que outros serviços, desde que não compreendidos na competência tributária dos municípios, também sejam inseridos na base de cálculo do ICMS (quando houver fornecimento de mercadorias combinadas com serviços correlatos). Essa previsão colabora para fomentar conflitos de competências entre os Estados e os municípios brasileiros. Some-se a isso a intenção dos Estados em alargar o conceito de prestação de serviço de comunicação, para tentar ampliar a sua real competência. $^{458}$

Há imunidade para a exportação de mercadorias e serviços prestados a destinatários no exterior, assegurada a manutenção integral dos créditos antecedentes; sobre operações que destinem a outros Estados petróleo, lubrificantes, combustíveis líquidos e gasosos dele derivados e energia elétrica (que são tributados no destino); para o ouro, nas mesmas condições estabelecidas para o IPI; e também para as prestações de serviço de comunicação nas modalidades de radiodifusão sonora e de sons e imagens de recepção livre e gratuita. ${ }^{459}$

\footnotetext{
${ }^{456}$ BRASIL. Supremo Tribunal Federal. Repercussão Geral. ARE n. 665134. Relator Ministro Joaquim Barbosa. Boletim de Jurisprudência Tributária, Belo Horizonte, Lexlegis, v. 1, p. 20-25, mar. 2014.

${ }^{457}$ BRASIL. Constituição (1988). Constituição da República Federativa do Brasil. Brasília, DF: Senado, 2014. Artigo 155, § 20, IX, "b".

${ }^{458}$ Como exemplos, podemos citar o provimento de acesso à internet e hospedagem de sites, a comunicação visual possibilitada por placas, painéis, outdoors. A problemática que envolve a tributação dos serviços foi objeto de estudo aprofundado na seguinte obra: MOREIRA, André Mendes. A tributação dos serviços de comunicação. São Paulo: Dialética, 2006.

${ }^{459}$ BRASIL. Constituição (1988). Constituição da República Federativa do Brasil. Brasília, DF: Senado, 2014. Artigo 155, § 20, X, "a" a "d".
} 
Os contribuintes do imposto são os produtores, os extratores, as indústrias, os comerciantes e os prestadores de serviços que concretizarem as hipóteses de incidência delineadas, entretanto, no tocante as operações mercantis, agiganta-se a responsabilidade atribuída a terceiros pelo mecanismo da substituição tributária prospectiva, prevista no parágrafo $7^{\circ}$ do artigo 150 da Constituição Federal, maculando a plurifasia, a não cumulatividade e outros princípios constitucionais inerentes ao ICMS. ${ }^{460}$

A base de cálculo nas importações compreende o valor que serviu de base para os tributos aduaneiros acrescido dos tributos federais, das despesas aduaneiras e do próprio ICMS. $^{461}$

A base de cálculo nas operações de circulação realizadas no país compreende o valor da mercadoria (já acrescido do próprio imposto) e poderá ainda ser acrescida do valor do IPI, dependendo da destinação que o adquirente der ao bem, conforme estabelece o texto constitucional ${ }^{462}$. Como realçado, o tributo incidirá sobre ele mesmo e sobre os demais tributos que alcançam o consumo, contribuindo para majorar, de forma indireta, o resultado da exação.

Nas prestações de serviços, a base de cálculo é o valor deles, sendo válidas as mesmas reflexões sobre o aumento causado pela repercussão das demais espécies tributárias no preço final da mercadoria ou do serviço.

As alíquotas do ICMS seguem regras rígidas e complexas esquadrinhadas na Constituição Republicana, sensível à necessária divisão do tributo entre os Estados produtores e Estados consumidores, de modo que a nossa tributação regionalizada não

\footnotetext{
${ }^{460}$ Sobre esse tema, escrevi: “[...] há algo preocupante no reino do ICMS: o aumento indiscriminado da cobrança do imposto mediante a responsabilidade por substituição tributária prospectiva (para frente). Nessa modalidade, a lei atribui a terceiro (geralmente, o industrial ou o importador) a responsabilidade pelo recolhimento do imposto incidente em todas as etapas de circulação da mercadoria, até o consumidor final. Como os fatos geradores ainda não ocorreram no mundo real, compete ao fisco presumir o valor sobre o qual recairá o imposto. Enquanto o Supremo Tribunal Federal (STF) não decide a questão, nenhum Estado brasileiro devolve ao contribuinte o valor recolhido em excesso, após o confronto do imposto estimado e o efetivamente devido. Nos últimos anos, em todo o território nacional, o rol de mercadorias alcançadas pela substituição tributária aumentou exponencialmente, o que agrava os problemas inerentes à complexa aplicação de suas regras. A responsabilidade por substituição, anteriormente aplicada a casos excepcionais, ocupa hoje lugar de destaque em matéria de ICMS. O tema ainda desperta controvérsias, a despeito da declaração de sua constitucionalidade pelo Tribunal Excelso. É nítida a ofensa aos princípios da tipicidade (proibição de presunção na tributação), da não cumulatividade - para os substituídos - e do respeito à capacidade contributiva (por onerar o contribuinte de direto, na impossibilidade de repasse integral ao consumidor)." (RIOS, Marcelo Jabour. Valor on line. Blog Fio da Meada - decifrando as leis e os tributos do país. Disponível em: <http: Ilwww.valor.com.br>. Acesso em: 08 out. 2014.

${ }^{461}$ A respeito da inclusão do ICMS em sua própria base de cálculo, majorando-a, ver as lições de Carrazza, que a considera flagrantemente inconstitucional, mesmo que a regra tenha sido promovida por Emenda Constitucional (CARRAZZA, Roque Antônio. ICMS. 9. ed., rev. e ampl. de acordo com a Lei Complementar 87/96 e suas ulteriores modificações. São Paulo: Malheiros, 2002).

${ }^{462}$ BRASIL. Constituição (1988). Constituição da República Federativa do Brasil. Brasília, DF: Senado, 2014. Artigo 155, § $2^{\circ}$, XI.
} 
ficasse concentrada só na origem ou apenas no destino das mercadorias e serviços. A técnica adotada foi a do compartilhamento.

Em síntese: em primeiro lugar, os Estados e o Distrito Federal definem as suas alíquotas internas, norteados pela seletividade, sendo facultado ao Senado Federal estabelecer alíquotas máximas ${ }^{463}$ e mínimas ${ }^{464}$ para essas operações. As alíquotas interestaduais, inferiores às internas, são definidas por meio de resoluções do Senado Federal $^{465}$. A partir desse esquema, a alíquota interestadual pertence ao Estado de origem da mercadoria ou do serviço e a diferença (entre a interna e a interestadual) ao de destino.

Ressalve-se que a partilha acima somente é utilizada nas operações e prestações interestaduais praticadas entre contribuintes do imposto. Sempre que o destinatário for uma pessoa física ou uma pessoa jurídica não inscrita no cadastro de contribuintes, aplica-se a alíquota interna prevista para a operação ou prestação, de forma que o recolhimento seja integralmente reconhecido para o Estado de origem. Essa regra constitucional, após o advento da internet e do crescimento do comércio eletrônico, merece ser revista. ${ }^{466}$

Um dos aspectos mais caros ao ICMS diz respeito ao reconhecimento do princípio da não cumulatividade, como corolário lógico e justo dos tributos incidentes sobre todas as fases de circulação da mercadoria, ditos plurifásicos. Não observá-lo, ou reduzi-lo, implica adotar um efeito econômico regressivo e permitir que o tributo seja exigido em cascata, sempre a incidir sobre os valores anteriormente tributados.

${ }^{463}$ É facultado ao Senado Federal fixar alíquotas máximas para resolver eventual conflito específico que envolva interesse dos Estados e do Distrito Federal, mediante resolução de iniciativa da maioria absoluta e aprovada por dois terços de seus membros (BRASIL. Constituição (1988). Constituição da República Federativa do Brasil. Brasília, DF: Senado, 2014.Artigo 155, § 2, V, “b”).

${ }^{464}$ É facultado ao Senado Federal estabelecer alíquotas mínimas mediante resolução de iniciativa de um terço e aprovada pela maioria absoluta de seus membros (BRASIL. Constituição (1988). Constituição da República Federativa do Brasil. Brasília, DF: Senado, 2014. Artigo 155, § 20, V, "a").

465 Atualmente vigoram as Resoluções do Senado ns. 22/89 e 13/2012.

466 Sobre essa questão, escrevi: "[...] pelas regras vigentes, o tributo é compartilhado entre os entes envolvidos nas operações interestaduais apenas quando o destinatário é contribuinte do imposto. Nas demais hipóteses, é integralmente devido para a unidade da federação de origem da mercadoria ou serviço, razão do descontentamento de grande parte dos Estados e do Distrito Federal. O tema ganhou destaque após a assinatura, no Confaz, do Protocolo $\mathrm{n}^{\mathrm{o}} 21$, de 2011 , que estabeleceu um imposto complementar a ser recolhido a favor dos signatários, nas aquisições efetuadas por particulares pela internet, telemarketing ou showroom. A exigência aplica-se, inclusive, nas hipóteses de aquisição de bens provenientes dos Estados que não assinaram a norma. Considerando que o instrumento utilizado é flagrantemente inconstitucional, o Supremo Tribunal Federal (STF) concedeu a medida liminar suspendendo a cobrança complementar, dando claros sinais de que a alteração da tributação do e-commerce exige reforma constitucional. Reputo que a iniciativa de alterar a sistemática de partilha do ICMS, para o caso apresentado, é legítima. Em 1988, o fenômeno das vendas pontocom não poderia sequer ser imaginado, fato que justifica a revisão constitucional das regras pactuadas." (RIOS, Marcelo Jabour. Valor on line. Blog Fio da Meadadecifrando as leis e os tributos do país. Disponível em: 〈http:॥www.valor.com.br>. Acesso em: 08 out. 2014). É de notar que tramita no Congresso Nacional a Proposta de Emenda Constitucional (PEC) n. 197, de 2012, que tem como proposta alterar a sistemática de cobrança do ICMS praticada nessa hipótese, de forma a partilhar o imposto. 
A melhor doutrina considera que a Constituição Federal, ao elencar as duas únicas hipóteses em que se admite o fenômeno da cumulatividade para o ICMS, cerrou a possibilidade de novos obstáculos a serem criados pela legislação infraconstitucional, corrente que adotamos.

Apesar disso, a lei complementar que disciplina o imposto, após sucessivas alterações, restringiu o crédito do imposto cobrado na aquisição de bens de uso e consumo (para todos os contribuintes), de energia elétrica (para os contribuintes em geral, exceto exportadores, industriais e produtores de energia) e de serviço de comunicação (para os contribuintes em geral, exceto exportadores e prestadores de serviço de comunicação), colocando em risco a neutralidade almejada.

As regras de apuração e recolhimento do imposto são disciplinadas pelas legislações ordinárias dos Estados e do Distrito Federal, que usualmente adotam a sistemática mensal de apuração, mediante o confronto de débitos e créditos (não cumulatividade), sendo o tributo recolhido no mês subsequente. Os créditos porventura existentes são transferidos para os meses seguintes e, na hipótese de sua acumulação, dependerá da lei ordinária estadual estabelecer condições para a sua utilização. A garantia constitucional de restituição desse valor somente contemplou os exportadores.

Embora a Constituição Federal tenha atribuído um relevante papel à lei complementar para engessar as regras de concessão de isenções e benefícios fiscais em matéria de ICMS (a norma vigente ${ }^{467}$ exige a aprovação unânime das unidades da federação), de modo a preservar o caráter nacional do tributo, essa não tem sido a tônica dos relacionamentos entre os Estados. Alastrou-se na federação a chamada guerra fiscal, que causa dois efeitos danosos ao pacto federativo: o não exercício da competência tributária e as graves ofensas ao princípio da não cumulatividade. ${ }^{468}$

${ }^{467}$ BRASIL. Lei Complementar n. 24, de 7 de janeiro de 1975. Dispõe sobre os convênios para a concessão de isenções do imposto sobre operações relativas à circulação de mercadorias, e dá outras providências. Parcialmente recepcionada pela CR/88. Disponível em: 〈http: Iwww.planalto.gov.br>. Acesso em: 05 ago. 2014.

${ }^{468}$ A esse respeito, já manifestei a seguinte opinião: “A guerra fiscal que contaminou toda a federação é a principal causa do não exercício do poder de tributar. Explico: com o objetivo de atrair contribuintes para o seu território, os Estados reduzem a carga tributária de alguns setores da economia unilateralmente, sem requerer a anuência dos demais entes federados. De forma reativa, os prejudicados adotam medidas não menos ofensivas ao nosso ordenamento jurídico: limitam os créditos relacionados às aquisições de mercadorias beneficiadas, na mesma proporção da redução concedida na origem; e concedem o mesmo tratamento privilegiado para os contribuintes locais, criando um círculo vicioso de renúncia de receitas. Há quem defenda o privilégio fiscal como medida de redução das desigualdades regionais. Afinal, afirmam, fundamos a federação com esse propósito. Para pôr fim aos conflitos existentes, bastaria alterar a exigência de aprovação unânime dos Convênios que autorizam as benesses fiscais, prevista na Lei Complementar $\mathrm{n}$. 24, de 1975. Embora nobre o propósito, penso não ser a opção adequada. O resultado, já conhecido, não é satisfatório. O ICMS nasceu para ser neutro e atingir quem possui capacidade contributiva, de forma 
Finalizando, cumpre lembrar que as microempresas e as empresas de pequeno porte optantes pelo regime do Simples Nacional ficam vedadas de apropriar créditos nas suas aquisições, mas poderão gerar créditos aos adquirentes das mercadorias e serviços, entretanto deverá ser observada a alíquota vigente para o contribuinte, conforme faixa de enquadramento no regime (sempre inferiores às alíquotas reais do ICMS). Inegável tratarse de mais um obstáculo ao princípio da não cumulatividade.

Após as considerações propostas, podemos elaborar a regra-matriz do ICMS:

\section{Regra-matriz do ICMS na circulação de mercadorias, prestações de serviço de transporte e serviço de comunicação no mercado interno}

\begin{tabular}{|l|l|}
\hline \multicolumn{2}{|l|}{ Hipótese: } \\
\hline Critério material & $\begin{array}{l}\text { a) Realizar operações relativas à circulação de mercadorias } \\
\text { b) Prestar serviço de transporte interestadual ou intermunicipal } \\
\text { c) Prestar serviço oneroso de comunicação }\end{array}$ \\
Critério espacial & $\begin{array}{l}\text { Âmbito territorial do Estado ou do Distrito Federal. } \\
\text { Momento da saída da mercadoria ou da prestação do serviço de transporte ou de } \\
\text { Critério temporal }\end{array}$ \\
\end{tabular}

\begin{tabular}{|l|ll|}
\hline \multicolumn{1}{|l|}{ Consequentes: } & Sujeito ativo: & Estado ou Distrito Federal \\
\hline Critério pessoal & Sujeito passivo: & O produtor, industrializador, revendedor, comerciante que \\
& & praticou a operação relativa à circulação de mercadoria, o \\
& prestador de serviço oneroso de comunicação e o prestador de \\
& serviço de transporte, exceto o estritamente municipal \\
& Base de cálculo: & O valor da operação de circulação de mercadoria ou o valor da \\
& prestação de serviço \\
& Anterna, conforme definido pela legislação interna, norteada \\
& pela seletividade. Interestadual, conforme definida pelas \\
& resoluções do Senado Federal \\
& Tributo a recolher: & $\begin{array}{l}\text { Resultado do confronto de débitos-créditos apurados no mês. } \\
\text { Tributo sujeito a não cumulatividade }\end{array}$ \\
&
\end{tabular}

seletiva. Deve ser respeitado o seu perfil nacional e uniforme, caso contrário, perderá força e valor. Carga tributária excessiva - para alguns - ou manifestação de riqueza não tributada - para outros - contrariam a ideia de justiça tributária." (RIOS, Marcelo Jabour. Valor on line. Blog Fio da Meada-decifrando as leis e os tributos do país. Disponível em: 〈http: |lwww.valor.com.br>. Acesso em: 08 out. 2014). Ainda sobre o tema, sugere-se a leitura da seguinte obra: CARVALHO, Paulo de Barros; MARTINS, Ives Gandra da Silva. Guerra fiscal: reflexões sobre a concessão de benefícios no âmbito do ICMS. São Paulo: Noeses, 2012. 


\section{Regra-matriz do ICMS na importação de mercadorias}

\begin{tabular}{|l|l|}
\hline \multicolumn{2}{|l|}{ Hipótese: } \\
\hline Critério material & Importar mercadorias do exterior \\
Critério espacial & Repartições alfandegárias \\
Critério temporal & O momento do desembaraço aduaneiro \\
\hline
\end{tabular}

\section{Consequentes:}

\begin{tabular}{|c|c|c|}
\hline \multirow[t]{2}{*}{ Critério pessoal } & Sujeito ativo: & Estado ou Distrito Federal \\
\hline & Sujeito passivo & Importador \\
\hline \multirow[t]{3}{*}{ Critério quantitativo } & Base de cálculo & $\begin{array}{l}\text { O preço que servir de base para o cálculo dos tributos } \\
\text { aduaneiros, acrescido do montante destes e dos encargos } \\
\text { cambiais devidos pelo importador, despesas aduaneiras e o } \\
\text { próprio ICMS }\end{array}$ \\
\hline & Alíquota & Aquela prevista para as operações internas da mercadoria \\
\hline & Tributo a recolher & Devido no momento do desembaraço aduaneiro \\
\hline
\end{tabular}

\subsection{O ISSQN dos municípios}

Compete aos municípios instituir o imposto sobre serviços de qualquer natureza (ISSQN), desde que não compreendidos na competência do ICMS e definidos em lei complementar. ${ }^{469}$

A doutrina nacional aponta a incongruência entre a expressão "serviço de qualquer natureza" constante do texto constitucional e a necessidade de um rol descritivo e taxativo dos tais serviços, de modo a delimitar o exercício de competência dos municípios. Mas essa foi a metodologia adotada pela Lei Complementar n. 116/2003, que rege a matéria. ${ }^{470}$

Para Sacha Calmon, a norma, de forma abrangente, deveria apenas definir os serviços como "obrigação de fazer", identificar os casos em que é possível separar mercadorias e serviços, para se evitar conflitos de competência e "não fechar a lista, deixando os municípios competentes para exaurir os fatos jurígenos". 471

Aires Fernandino Barreto não discrepa:

\footnotetext{
${ }^{469}$ BRASIL. Constituição (1988). Constituição da República Federativa do Brasil. Brasília, DF: Senado, 2014. Artigo 156, inciso III, com redação dada pela Emenda Constitucional n. 3, de 1993.

${ }^{470}$ BRASIL. Lei Complementar n. 116, de 13 de julho de 2003. Dispõe sobre o Imposto sobre Serviços de Qualquer Natureza, de competência dos Municípios e do Distrito Federal, e dá outras providências.

${ }^{471}$ COÊLHO, Sacha Calmon Navarro. Curso de direito tributário brasileiro. Rio de Janeiro: Forense, 2005. p. 435 .
} 
[...] a definição, por lei complementar, de serviços tributáveis pelos Municípios agride frontalmente a autonomia municipal porque, se a lei complementar pudesse definir os serviços tributáveis, ela seria necessária e, pois, intermediária entre a outorga constitucional e o exercício atual da competência, por parte do legislador ordinário do município. ${ }^{472}$

Acrescentamos a essas reflexões dois outros problemas desencadeados pela adoção de uma lista taxativa: a tentativa de inclusão de hipóteses que não se amoldam ao conceito de prestação de serviços (obrigação de fazer) e a exclusão de serviços típicos, deixando de fora do mundo da fiscalidade uma possível manifestação de riqueza. ${ }^{473}$

O imposto incide também sobre o serviço proveniente do exterior ou cuja prestação tenha iniciado no exterior, mas não alcança as exportações de serviços para fora do país, salvo se os resultados aqui se verifiquem, ainda que o pagamento seja feito por residente no exterior.

O município competente para cobrar o tributo, de acordo com o artigo $3^{\circ}$ da Lei Complementar n. 116/2003, é aquele em que estiver estabelecido o prestador, exceto para aquelas hipóteses elencadas nos incisos I a XXII do caput do mesmo artigo, que atribuem competência ao município da efetiva prestação do serviço contratado. A regra, portanto, é mista e está norteada pelo princípio da praticidade e da certeza da arrecadação.

Embasados em farta jurisprudência do Superior Tribunal de Justiça ${ }^{474}$, diversos municípios, quando lhes convêm, não acatam a cisão proposta pela norma e exigem o imposto sobre os serviços prestados no seu território, inclusive daqueles que deveriam

${ }^{472}$ BARRETO, Aires Fernandino. ISS na Constituição e na lei. 2. ed. rev. ampl. e atual. São Paulo: Dialética, 2005. p. 41.

${ }^{473}$ Há várias discussões no Supremo Tribunal Federal a respeito da incidência do ISSQN fora do âmbito das obrigações de fazer. Como boas referências, podemos citar: a) BRASIL. Supremo Tribunal Federal. Repercussão Geral. Recurso Extraordinário RE n. 592905, de relatoria do Ministro Eros Grau. Boletim de Jurisprudência, Belo Horizonte, Lexlegis, v. 2, p. 116-128, abr. 2014, que discutiu a incidência do ISSQN sobre o leasing; b) BRASIL. Supremo Tribunal Federal. Repercussão Geral. Recurso Extraordinário RE n. 626706. Boletim de Jurisprudência, Belo Horizonte, Lexlegis, v. 1, p. 51-52, mar. 2014, que discutiu a incidência do ISSQN na locação de bens e resultou na seguinte Súmula vinculante: Súmula Vinculante 31: "É inconstitucional a incidência do Imposto sobre Serviços de Qualquer Natureza - ISS sobre operações de locação de bens móveis"; c) BRASIL. Supremo Tribunal Federal. Repercussão Geral. Recurso Extraordinário RE n. 603136, de relatoria do Ministro Gilmar Mendes. Boletim de Jurisprudência, Belo Horizonte, Lexlegis, v. 3, p. 98-108, mai. 2014, que discutiu a incidência do ISSQN sobre a franquia; d) BRASIL. Supremo Tribunal Federal. Repercussão Geral. Recurso Extraordinário RE n. 592905, de relatoria do Ministro Eros Grau. Boletim de Jurisprudência, Belo Horizonte, Lexlegis, v. 2, p. 116-128, abr. 2014, que discute a incidência do ISSQN sobre a incidência nos contratos de licenciamento ou de cessão de programas de computador (software) desenvolvidos para clientes de forma personalizada.

${ }^{474}$ Como referência, indicamos: BRASIL. Superior Tribunal de Justiça. Agravo Regimental no Recurso Especial AgRg no REsp n. 1390900/MG. DJe 20/05/2014. Disponível em: <http://www.stj.jus.br>. Acesso em: 20 out. 2014. 
gerar receitas para a localidade do prestador, nutrindo conflitos de competência entre os seus pares e prejudicando os contribuintes, que não sabem a que potestade devem servir. ${ }^{475}$

O sujeito passivo é aquele que presta o serviço, embora a obrigatoriedade de retenção e recolhimento do tributo seja cada vez mais atribuída aos tomadores dos serviços (vinculados ao fato gerador da respectiva obrigação tributária).

A Lei Complementar n. 116/2003 já estabelece duas hipóteses de responsabilidade atribuídas ao tomador dos serviços que devem ser obrigatoriamente acolhidas pelo legislador ordinário: na importação e naquelas em que se considera ocorrido o fato gerador no território da efetiva prestação de serviços (as exceções elencadas nos incs. I a XXII do art. $\left.3^{\circ}\right)$.

A base de cálculo do imposto é o preço do serviço prestado, portanto o tributo incide sobre ele mesmo e também sobre o valor do PIS e da COFINS, se existentes.

Cabe à lei complementar fixar as suas alíquotas máximas e mínimas ${ }^{476}$, excluir da sua incidência exportações de serviços para o exterior e regular a forma e as condições como isenções, incentivos e benefícios fiscais serão concedidos e revogados.

Em relação ao eventual conflito de competências com o ICMS, a norma dispõe que nos serviços que envolva fornecimento de mercadorias, o ISSQN abrangerá o todo, salvo quando houver previsão expressa na lista anexa à Lei Complementar n. 116/2003.

Nesse sentido, podemos elaborar a seguinte regra-matriz do tributo:

\section{Regra-matriz do ISSQN no mercado interno}

\begin{tabular}{|l|l|}
\hline Hipótese: \\
\hline Critério material & Prestar serviços \\
Critério espacial & Âmbito territorial do município e do Distrito Federal \\
Critério temporal & Momento em que o serviço, pronto e acabado, é entregue ao tomador \\
\hline
\end{tabular}

\footnotetext{
${ }^{475}$ A definição do sujeito ativo competente para a cobrança do ISSQN foi apreciado pelo Supremo Tribunal Federal no agravo de instrumento interposto contra decisão que inadmitiu recurso extraordinário em que se discute se o sujeito ativo competente é o município em que foi prestado o serviço ou em que foi localizado o estabelecimento do prestador, e o tribunal decidiu que a questão é infraconstitucional, conforme Agravo de Instrumento n. 790.283, rel. Min. Gilmar Mendes.

${ }^{476}$ BRASIL. Constituição (1988). Constituição da República Federativa do Brasil. Brasília, DF: Senado, 2014. Artigo 156, $\S 3^{\circ}$, com redação dada pela Emenda Constitucional n. 37, de 2002. A alíquota máxima foi, de fato, definida pela LC n. 116/2003. A mínima continua sendo regida pelo artigo 88 do Ato das Disposições Constitucionais Transitórias (ADCT).
} 


\begin{tabular}{|c|c|c|}
\hline \multicolumn{3}{|l|}{ Consequentes: } \\
\hline Critério pessoal & Sujeito ativo: & Municípios e o Distrito Federal \\
\hline \multirow{4}{*}{ Critério quantitativo } & Sujeito passivo: & O prestador dos serviços \\
\hline & Base de cálculo: & O valor da prestação de serviços \\
\hline & Alíquota: & Mínima: 2\%; Máxima: 5\% \\
\hline & Tributo a recolher: & $\begin{array}{l}\text { Resultado da aplicação da alíquota sobre a base de cálculo, no } \\
\text { período de apuração. Tributo cumulativo }\end{array}$ \\
\hline
\end{tabular}

\section{Regra-matriz do ISSQN na importação de mercadorias}

\begin{tabular}{|c|c|c|}
\hline \multicolumn{3}{|l|}{ Hipótese: } \\
\hline Critério material & \multicolumn{2}{|c|}{ Importar serviços do exterior } \\
\hline Critério espacial & \multicolumn{2}{|c|}{ Conforme legislação ordinária } \\
\hline Critério temporal & \multicolumn{2}{|c|}{ Conforme legislação ordinária } \\
\hline \multicolumn{3}{|l|}{ Consequentes: } \\
\hline \multirow[t]{2}{*}{ Critério pessoal } & Sujeito ativo: & Municípios e o Distrito Federal \\
\hline & Sujeito passivo & Importador \\
\hline \multirow[t]{3}{*}{ Critério quantitativo } & Base de cálculo & $\begin{array}{l}\text { O preço que servir de base para o cálculo dos tributos } \\
\text { aduaneiros, acrescido do montante destes e dos encargos } \\
\text { cambiais devidos pelo importador, despesas aduaneiras e o } \\
\text { próprio ISSQN }\end{array}$ \\
\hline & Alíquota & Mínima: 2\%; Máxima: 5\% \\
\hline & Tributo a recolher & Conforme legislação ordinária \\
\hline
\end{tabular}




\section{CONCLUSÕES}

O Estado contemporâneo deve posicionar-se frente aos desafios impostos pela globalização econômica e pelo fenômeno dos países que se aproximam, estabelecem objetivos comuns e promovem ações coordenadas.

No cenário internacional, estimulados pelo modelo europeu de integração econômica, surgiram acordos inovadores que superaram os anseios dos tradicionais tratados de livre comércio entre países soberanos e buscaram estabelecer um novo ambiente de liberdades, até então vivenciadas exclusivamente nos limites das fronteiras do Estado nação.

Esse mercado comum, nomenclatura adotada pela União Europeia e pelo MERCOSUL, é compreendido como um espaço onde circulam livremente pessoas, serviços, mercadorias e capitais. Exige, por óbvio, reforma dos sistemas constitucionais, um grau elevado de harmonização legislativa e coordenação de políticas econômicas, sociais e fiscais.

A tese chegou a várias conclusões, que podem ser assim sumarizadas:

1. A experiência mundial exitosa de constituição do mercado comum entre Estados foi a vivenciada pela União Europeia.

2. O sucesso europeu assentou-se na solidez de suas instituições e no reconhecimento da supremacia do direito comunitário.

3. O mercado comum foi erigido, dentre outros pilares, por meio do processo de harmonização das legislações tributárias dos Estados membros, em especial as que alcançam o consumo de bens e serviços, razão pela qual é reconhecido, pela doutrina e jurisprudência comunitárias, como um dos principais responsáveis pelo processo de integração.

4. O desenrolar dos compromissos de integração firmados internacionalmente dependem dos poderes e das competências atribuídas às instituições que deverão conduzir o processo. O modelo supranacional criado pela União Europeia provou ser capaz de erigir um mercado comum e promover a aproximação das legislações dos Estados membros, nos campos necessários estabelecidos pelos objetivos comuns.

5. Não se constrói um mercado comum sem a harmonização legislativa fiscal em grau elevado. É necessário estabelecer o equilíbrio, para evitar a fuga de pessoas, bens e 
capitais, e assegurar a livre concorrência, antes da remoção das barreiras físicas, técnicas e fiscais.

6. Estabelecido o compromisso de constituição de um mercado comum, a harmonização legislativa deverá ser conduzida observando-se os seguintes quadrantes: eleição do tema a ser harmonizado; dimensionamento do grau de aproximação legislativa necessário para alcançar os objetivos acordados; definição dos meios que serão utilizados para a sua implementação (abrangendo o seu desenvolvimento, a forma de introdução das modificações no ordenamento jurídico interno dos Estados membros); os mecanismos a serem utilizados para assegurar a interpretação e aplicação uniforme das normas.

7. O maior desafio a ser superado pelos Estados que pretendem constituir um mercado comum é encontrar uma forma eficaz para entronizar e reconhecer o novo direito face ao ordenamento jurídico nacional e garantir uma interpretação uniforme, assegurada pela existência de um tribunal permanente e supranacional.

8. O acervo comunitário da União Europeia denota o processo de harmonização das legislações tributárias dos Estados membros, iniciada pela adoção obrigatória do IVA como o imposto indireto e em fase de conclusão de harmonização dos critérios que compõem a norma impositiva do tributo.

9. A escolha do tipo de tributação, influenciada pela experiência francesa de tributação do consumo, foi baseada nos seguintes critérios valorativos: (i) atendia aos anseios fiscais de arrecadação, posto que o tributo é arrecado em todo o circuito econômico (plurifasia); (ii) favorecia a economia e não causava distorções no mercado interno, por ser neutro e não piramidal, já que permite a dedução do tributo já cobrado anteriormente (não cumulatividade); (iii) permitiu a definição de bases comuns para que parte de sua arrecadação fosse direcionada à construção do mercado comum (recursos próprios).

10. Para implementar as reformas dos sistemas tributários, os países europeus superaram e encontraram soluções que podem servir de modelo aos países mercosulinos.

11. O mercado comum europeu somente avançou após o Ato Único Europeu ter conduzido à harmonização da legislação tributária sobre o consumo, já prevista no Tratado de Roma, mediante estabelecimento de metas, prazos, ações e intensiva cobrança por resultados.

12. O Tribunal de Justiça exerceu um papel fundamental na construção da União Europeia, como verdadeiro guardião dos objetivos traçados nos tratados comunitários e também inovou, ao estabelecer novos princípios e ampliar o que previam os acordos. 
13. Na UE os países fundantes praticavam modelos muito distintos de tributação sobre o consumo, que poderiam afetar a concorrência e as devoluções de tributos aos exportadores, comprometendo a dinâmica do mercado comum.

14. O MERCOSUL foi idealizado para atingir o patamar de um mercado comum e reconhecer, entre os seus membros, as quatro liberdades fundamentais de um mercado integrado. Como a harmonização das legislações fiscais constitui uma etapa fundamental para a consecução desse espaço econômico sem fronteiras, devem ser iniciados esforços para a adoção de tipos impositivos que permitam a harmonização.

15. É possível erigir um mercado comum mantendo-se o modelo intergovernamental de acordo internacional, entretanto o caminho a percorrer dependerá exclusivamente da vontade dos Estados, o que dificulta, ou quase inviabiliza, a sua concretização. A potestade tributária é sempre o último pilar a ser negociado pelos Estados e, na ausência de instituições supranacionais para garantir a unidade, adia-se o compromisso de harmonização das legislações.

16. O MERCOSUL, conforme princípios pactuados, deve promover a eliminação de entraves para assegurar as quatro grandes liberdades, estabelecer uma tarifa externa comum e adotar uma política coordenada, a fim de garantir condições adequadas de concorrência entre os países e fortalecer o processo de integração, mediante a harmonização das legislações pertinentes. Nenhuma das três propostas caminhou a contento.

17. Faz-se necessária, em prol da integração, uma revisão da sua estrutura institucional, notadamente em relação à forma de incorporação do direito mercosulino nos ordenamentos jurídicos dos Estados partes e à garantia de interpretação unificada de suas normas.

18. Como o MERCOSUL foi erigido para atingir o estágio de um mercado comum, pressupõe-se que as quatro grandes liberdades não deverão encontrar barreiras de nenhuma natureza, especialmente as tributárias.

19. A análise dos sistemas tributários dos países integrantes do MERCOSUL foi realizada com o objetivo apurar se há possibilidade de avanço da integração, já que é um dos pilares mais importantes na construção do mercado comum. Comparados os tipos impositivos e os critérios da norma instituidora (material, temporal, espacial, pessoal, quantitativo), foi possível constatar as similitudes e dessemelhanças existentes entre os países do MERCOSUL. 
20. Na Argentina, os impostos indiretos são de competência concorrente entre o Estado Federal e as províncias, o que ocasiona uma sobreposição de impostos. Além do IVA e do imposto seletivo ao consumo, vigora o imposto provincial sobre os ingressos brutos (províncias). Essa competência dupla tem forte impacto na possibilidade de harmonização das legislações tributárias no MERCOSUL e vem sendo questionada pelos doutrinadores argentinos, que sugerem a sua agregação ao IVA, fato que deverá ocorrer para a futura harmonização com os demais parceiros do MERCOSUL. Não se impõe alteração constitucional para resolver a questão da unificação da tributação, com a manutenção apenas do IVA e imposto seletivo ao consumo existentes na federação. A tese demonstra que o pacto firmado pela Nação é o instrumento que historicamente vem conduzindo a tributação na Argentina, com a garantia de repasse de parte da receita arrecadada, imediata e preferencialmente aos entes subnacionais, de forma satisfatória.

21. O Paraguai é um Estado unitário, divido em departamentos, municípios e distritos que gozam de certa autonomia política, administrativa e normativa e poderes para arrecadar os seus recursos. O país adota um modelo de repartição de competências bem simples: (i) ao governo central compete a tributação sobre o comércio exterior; a renda e o consumo de bens e serviços; e (ii) os impostos sobre a propriedade pertencem ao poder subnacional. O sistema é composto por impostos, taxas e contribuições e é vedada a dupla imposição sobre o mesmo fato gerador da obrigação tributária, característica que deverá ser observada pelo IVA padrão mercosulino, para evitar o efeito danoso e antieconômico da bitributação. Outra característica importante a ser preservada é a exoneração tributária concedida às publicações, objetos e às atividades que possuem valor significativo para a difusão cultural, educação, investigação científica e tecnológica e as terras dos povos indígenas. O sistema tributário paraguaio passou por uma profunda reforma, que teve como objetivo primordial a reformulação da tributação do consumo, por meio da adoção do Imposto sobre o Valor Acrescido (IVA) plurifásico e não cumulativo, incidente sobre o fornecimento de bens e serviços e a adoção de um Imposto Seletivo sobre o Consumo, ambos fortemente influenciados pelo modelo europeu de tributação e favoráveis à aproximação legislativa para o desenvolvimento do MERCOSUL, que também prescinde de reforma constitucional.

22. A República Oriental do Uruguai é um Estado democrático, unitário, descentralizado e formado pelos governos departamentais e pelas autoridades locais. A Constituição do país não contém um capítulo dedicado ao sistema tributário nacional, não estabelece as espécies tributárias e a repartição de competências ou de receitas tributárias, 
que ficam a cargo do Poder Legislativo. A reforma estrutural da tributação indireta culminou com a eliminação dos impostos monofásicos e cumulativos e a adoção de dois tributos que incidem sobre o consumo, seguindo o padrão mundial das economias modernas: o Imposto sobre o Valor Agregado (IVA) e o Imposto Seletivo sobre o Consumo (ISC). O país encontra-se perfeitamente apto a avançar no processo de harmonização da legislação tributária no MERCOSUL.

23. A Constitución de la República Bolivariana de Venezuela estabelece que o país é um Estado democrático social de direito, que adota o modelo federal, descentralizado política e administrativamente, sendo o território nacional dividido em estados Distrito Federal, dependências federais e municípios e atribui o poder de tributar aos três níveis de governo: nacional, estadual e municipal. O poder de tributar está concentrado no poder central, a despeito da opção pelo federalismo e compromisso de descentralização e autonomia a ser conferida aos estados, Distrito Federal e municípios. Compete ao poder nacional editar a legislação que irá garantir a coordenação e a harmonização das distintas potestades tributárias, definir princípios, parâmetros e limitações dos tipos impositivos. Vigora na República Bolivariana da Venezuela um tributo geral sobre o consumo, incidente sobre o valor agregado (IVA) e diversos outros tributos sobre consumos específicos, tais como bebidas, cigarros e combustíveis, que comportam ser ajustados em um único tributo que alcance esses bens selecionados, para serem tributados de forma distinta do IVA, desde que coordenados com os demais países do MERCOSUL. O ingresso da Venezuela no bloco não dificultou o necessário processo de harmonização das legislações tributárias dos Estados fundadores do MERCOSUL.

24. As espécies tributárias vigentes na Argentina, Uruguai, Paraguai e Venezuela são compatíveis, devem sofrer pequenas modificações relacionadas à definição do que será tributado pelo IVA e o que será tributado pelo imposto seletivo sobre o consumo.

25. No Brasil, o sistema tributário foi definido na Carta Magna, e contém um capítulo especial que cuida da repartição de competências tributárias entre os entes, dos princípios e das limitações constitucionais ao poder de tributar e da repartição de receitas arrecadadas entre as pessoas políticas da federação.

26. O Brasil não adotou um amplo tributo sobre o consumo de bens e serviços. No sistema constitucional tributário, norteado pelo federalismo, todos os entes políticos da federação possuem competência tributária para instituí-los e cobrá-los.

27. Para a adoção do IVA no Brasil, é necessário unificar as contribuições PIS/COFINS, o Imposto sobre Produtos Industrializados (IPI); O Imposto sobre Circulação 
de Mercadorias e Serviços de Transporte e Comunicação (ICMS) e o Imposto sobre Serviços de Qualquer Natureza (ISSQN).

28. A opção da República Federativa do Brasil em atribuir competência compartilhada aos entes da federação não inviabiliza a adoção do IVA, desde que seja compensada mediante transferência direta e imediata de receita para os demais entes federados. Ademais, é possível estabelecer um período transitório de garantia de receitas, como experimentado por Portugal e também pela Argentina, quando adotaram o imposto geral sobre o consumo.

29. O modelo atual de repartição de receitas enfraquece o federalismo, comportando uma possível revisão do modelo. A ausência da neutralidade plena do tributo onera o setor produtivo, impacta negativamente o crescimento econômico da nação, reduz as chances de concorrência em um mercado globalizado e, por óbvio, inviabiliza o projeto de integração idealizado pelo Tratado de Assunção.

30. A adoção do IVA deverá representar um reforço ao federalismo no Brasil, em razão da eliminação dos conflitos de competências, da guerra fiscal, das renúncias de receitas e ofensas aos princípios constitucionais, hoje vivenciados em nosso país. A segurança jurídica alcançada pela unificação favorecerá o país, no plano interno e internacional.

31. Na ausência de instituições supranacionais, os Estados membros do MERCOSUL devem promover as reformas internas de forma coordenada para que possam, na etapa seguinte, utilizar as instituições do bloco para harmonizar os tipos impositivos comuns.

32. As repartições de competência tributária, no tocante à instituição do tributo, devem ser centralizadas no poder central, de modo a permitir uma maior inserção no mercado internacional e evitar os conflitos existentes na Argentina e, no Brasil, a guerra fiscal entre os poderes locais, que exercitam a não tributação como meio de atrair contribuintes para o seu território (guerra fiscal).

33. A análise dos sistemas tributários dos países que integram o MERCOSUL permite concluir que, em relação aos tributos indiretos, o modelo adotado pela República Federativa do Brasil representa um entrave ao sonho mercosulino.

34. O Brasil necessita reformar o seu sistema tributário, com a eliminação de entraves à integração no âmbito do MERCOSUL, mediante reforma do seu Estatuto Fundante. 


\section{BIBLIOGRAFIA :}

ABBAgNano, Nicola. Dizionario di filosofia. 2. ed. riv. e acres. Torino: Unione Tipografico Editrice Torinese (UTET), 1971.

ACCIOLY, Elizabeth. Mercosul e União Europeia- Estrutura Jurídico - Institucional. Curitiba: Juruá, 2010.

ACCIOLY, Hildebrando; CASELLA, Paulo Borba; NASCIMENTO E SILVA, G. E. Do. Manual de Direito Internacional Público. São Paulo: Saraiva, 2012.

ALBERTINI, Jean-Marie. Les mécanismes du sous-développement. Paris, Economie et Humanisme, 1967.

ALTAMIRANO, Alejandro C. Estrutura basica del Impuesto al Valor Agregado (IVA) en la Republica Argentina. In: BALTHAZAR, Ubaldo Cesar (Org.). Reforma tributária e Mercosul. Belo Horizonte:

Del Rey, 1999. p. 71-96.

AMARAL JÚNIOR, Alberto do. A solução de controvérsias na OMC. São Paulo: Atlas, 2008 .

AMARI, Emerico. Critica e storia di uma scienza delle legislazioni comparate. Roma: Rubbettino, 2005.

ANCEL, Marc. Utilità e metodi del diritto comparato: elementi d'introduzione generale allo studio comparato dei diritti. Camerino: Universita di Camerino, 1974.

ARENDONK, H. P. A. M. van. Citizens and taxation in the EU: fifty years after the Neumark Report. EC Tax Review, Kluwer Law Online, v. 21, n. 3, p. 144-156, 2012.

ASSIS, Gláucia de Oliveira. The Mexico-United States border: between the dream and the nightmare: the experiences of emigrants/immigrants in non-authorized trips in the global world. Cadernos Pagu, Campinas, SP, Unicamp, v. 31, p. 219-250, 2008.

ASSIS, Karoline Marchiori de. Segurança jurídica dos benefícios fiscais. Universidade de São Paulo, São Paulo, 2013. 453 p. Tese (Doutorado em Direito Tributário). Data de defesa: 24.05.2013. Orientador: Heleno Taveira Torres e Joachim Englisch. Biblioteca Central: R10-10-25.

ALEXANDRE, Mário. O regime do IVA nas transações intracomunitárias de bens. Colóquio sobre a internacionalização da economia e a fiscalidade. XXX aniversário do Centro de Estudos Fiscais, Lisboa: DGCI. 1993.

ALEXY, Robert. Teoria da Argumentação Jurídica: a Teoria do Discurso Racional com Teoria da Justificação Jurídica. $2^{\mathrm{a}}$ Ed. Trad. Por SILVA, Zilda Hutcinson Schild. São Paulo: Landy, 2001. 
AMARAL JÚNIOR, Alberto do. OMC e o Comércio Internacional. Aduaneiras, São Paulo, 2003.

AMARAL JÚNIOR, Alberto do. União Europeia. Aduaneiras, São Paulo, 2003.

ARAÚJO, Nadia de. Código do MERCOSUL: tratados e legislação. Rio de Janeiro: Renovar, 1998.

ATALIBA, Geraldo. Conflitos entre ICMS, ISS e IPI. Revista de Direito Tributário, $\mathrm{n}^{\circ}$. 7/8, janeiro a junho/1979, PP. 105-31.

ATALIBA, Geraldo. Hipótese de incidência tributária. $6^{\mathrm{a}}$ ed. São Paulo: Malheiros Editores, 2006.

ÁVILA, Humberto. Teoria dos Princípios - da Definição à Aplicação dos Princípios Jurídicos. $8^{\text {a }}$ Ed. São Paulo: Malheiros, 2008.

ÁVILA, Humberto. Segurança jurídica: entre permanência, mudança e realização no direito tributário. $2^{a}$ edição, revista atualizada e ampliada. São Paulo: Malheiros, 2012.

AZEVEDO, Maria Eduarda. A Europa em movimento: apostas e desafios no limiar do novo século. Lisboa: Calouste Gulberkian, 1997.

BADURA, Peter. A "identidade nacional" dos Estados Membros na Constituição da Europa. In: CUNHA, Paulo de Pitta e; QUADROS, Fausto de (Orgs.). Uma Constituição para a Europa. Instituto Europeu da Faculdade de Direito de Lisboa, British council, Goethe-Institut Lissabon, Institut Franco-Portugais. Coimbra: Almedina, 2004. p. 74-82.

BALLASSA, Bela. Teoria da Integração Económica. Tradução de Maria Filipa Gonçalves e Maria Elsa Ferreira. 3. ed. Lisboa: Clássica, 1982.

BALEEIRO, Aliomar. Direito Tributário Brasileiro. $11^{\mathrm{a}}$ Ed. Atualizado por Misabel Abreu Machado Derzi. Rio de Janeiro: Forense, 2010.

BALEEIRO, Aliomar. Limitações Constitucionais ao Poder de Tributar. $8^{\circ}$ Ed. Atualizado por Misabel Abreu Machado Derzi. Rio de Janeiro: Forense, 2010.

BALEEIRO, Aliomar. Limitações constitucionais ao poder de tributar. 7. ed. atualizada por Misabel Abreu Machado Derzi. Rio de Janeiro, Forense, 1997.

BALEEIRO, Aliomar. Uma introdução à Ciência das Finanças, 16 ${ }^{\mathrm{a}}$ Ed. Atualizado por DEJALMA DE CAMPOS. Rio de Janeiro: Forense, 2006.

BALTHAZAR, Ubaldo Cesar. Reforma Tributária \& MERCOSUL. Belo Horizonte: Del Rey, 1998.

BAPTISTA, Luiz Olavo; MERCADANTE, Araminta de Azevedo; CASELLA, Paulo Borba (Orgs.). Mercosul: das negociações à implantação. São Paulo: LTr, 1994. 
BARACHO, José Alfredo de Oliveira. Teoria geral da cidadania: a plenitude da cidadania e as garantias constitucionais e processuais. São Paulo: Saraiva, 1995.

BARBOSA, Rui. O habeas corpus e a imprensa. Obras completas de Rui Barbosa. Rio de Janeiro: Imprensa Oficial, 1893. v. 20, t. 4, p. 141.

BARRETO, Aires Fernandino. ISS na Constituição e na lei. 2. ed. rev. ampl. e atual. São Paulo: Dialética, 2005.

BARRETO, Paulo Ayres. Não - cumulatividade das contribuições e sua vinculação à forma de tributação do imposto sobre a renda. Revista do Advogado, v. 94, p. 130-135, 2007.

BARRETO, Paulo Ayres. Contribuições - regime jurídico, destinação e controle. 1 ed. São Paulo: Noeses, 2011. V. 1.

BARRETO, Paulo Ayres. A tributação sobre o consumo: simplicidade e justiça tributária. In: Eurico Marcos Diniz de Santi. (Org.). Tributação e Desenvolvimento: homenagem ao Professor Aires Barreto. 1 ed. São Paulo: Ed. Quartier Latin, 2011, pg. 529-546.

BARRETO, AIRES F.. Base de cálculo, alíquota e princípios constitucionais. Editora Max Limonad, São Paulo, 1998 (2 $2^{\mathrm{a}}$ edição).

BASTO, José Guilherme Xavier de. A adopção por Portugal do Imposto sobre o Valor Acrescentado (IVA) da Comunidade Económica Europeia. Comunicações 1, da Faculdade de Economia da Universidade de Coimbra: Coimbra, 1981.

BASTO, José Guilherme Xavier de. A tributação do consumo e a sua coordenação internacional. Lisboa: Centro de Estudos Fiscais, 1991.

BASTO, José Guilherme Xavier de. 1993 e a abolição das fronteiras fiscais. Associação dos Administradores Tributários Portugueses. A fiscalidade no Espaço Comunitário de 1993. Lisboa: Rei dos Livros, 1993.

BASTO, José Guilherme Xavier de. Perspectivas de evolução do Imposto sobre o Valor Acrescentado em Portugal. Estudos em homenagem ao Professor Doutor Antônio de Arruga Ferrer Correia. Coimbra, 1987.

BECKER, Alfredo Augusto. Teoria Geral do Direito Tributário, $4^{\mathrm{a}}$ Ed. São Paulo: Noeses, 2007.

BALLARINO, Tito. Manuale di Diritto dell'Unione Europea, 6a. Edição. Pádua, 2001, Cedam.

BERGÈRES, Maurice- Christian. Contentieux Communautaire, 1a edição, Paris, 1998, Presses Universitaires de France.

BERLIRI, Antonio. L'Imposta sul valore aggiunto. Milano: Giuffrè, 1971. 
BHAGWATI, Jagdish. Regionalism and multilateralism: an overview. In: DE MELO, Jaime; PANAGARIYA, Arvind (Eds.). New dimensions in regional integration. Cambridge: Cambridge University Press, 1996. p. 22-51.

BIDART CAMPOS, Germán José. El federalismo argentino desde 1930 hasta la actualidade. In: CARMAGNANI, Marcello (Coord.). Federalismos latinoamericanos: México, Brasil, Argentina. México, DF: El Colegio de México; Fondo de Cultura Económica, 1993. (Serie Estudios. Fideicomiso Historia de las Américas). p. 363-396.

BITTKER, Boris I.; LOKKEN, Lawrence. Federal taxation of income estates. Gifts, 2002.

BLANCO, Andrés. El impuesto al valor agregado. Montevidéu: Fundación de Cultura Universitária, 2004.

BLANCO, Sindolfo. El impuesto al valor agregado en el Paraguay. In: BALTHAZAR, Ubaldo Cesar (Org.). Reforma tributária e Mercosul. Belo Horizonte: Del Rey, 1999.

BLUMANN, Louis Dubouis- Claude. Droit Matériel de l'Union Eropéenne, Paris, 2001, Montch-restien.

BOBBIO, Norberto. Diário de um século: autobiografia. Organização de Alberto Pappuzzi; tradução de Daniela Versiani. Rio de Janeiro: Campus, 1998.

BOBBIO, Norberto. O tempo da memória: de senectute e outros escritos autobiográficos. São Paulo: Campus, 1997.

BOBBIO, Norberto. Teoria do Ordenamento Jurídico, 10ª Ed. Brasília: UNB, 1999.

BOSON, Gerson de Brito Mello. Constitucionalização do Direito Internacional. Belo Horizonte: Del Rey, 2000.

BORCHARDT. Klaus-Dieter. L'ABC du droit de l'Union Européenne. Luxembourg: Office des publications de l’Union Européenne, 2010.

BORDA, Dionisio. Paraguay: resultados de las reformas (2003-2005) y sus perspectivas. Santiago de Chile: CEPAL, 2007.

BULIT GOÑI, Enrique Guillermo. Convenio multilateral, distribución de ingresos brutos. Buenos Aires: Depalma, 1992.

BULIT GOÑI, Enrique Guillermo. Impuesto sobre los ingresos brutos. 2. ed. actual. y ampl. Buenos Aires: Depalma, 1997.

BOULOUIS, Jean. Droit institutionnel de l'Union Européenne, Montchréstien: Paris, 1997.

BUCHETT, Alan. VAT in the European Community. 2nd edition, Butterworths - London, Dublin and Edinburgh, 1992. 
CALHEIROS, José Maria de Albuquerque. Harmonização de legislações - que futuro? In: PEREIRA, André Gonçalves et al. Em torno da revisão do Tratado da União Europeia. Coimbra: Almedina, 1997. p. 134-144.

CAMPOS, D. Leite de. A harmonização fiscal na CEE. O direito comunitário e a construção europeia (colóquio). Coimbra: FDUC/Coimbra Editora, 1999.

CAMPOS, João Mota. Manual de Direito Comunitário. Lisboa: Fundação Calouste Gulbenkian, Portugal, 2002.

CANARIS, Claus-Wilhelm. Pensamento Sistemático e Conceito de Sistema na Ciência do Direito. $2^{\mathrm{a}}$ Ed. Trad. Por CORDEIRO, Antonio Menezes. Lisboa: Fundação Caloustre Gulbenkian, 1996.

CANOTILHO, José Joaquim Gomes. Direito Constitucional e Teoria da Constituição. $4^{\mathrm{a}}$ edição. Coimbra, Portugal: Livraria Almedina, 2006.

CARTOU, Louis. L'Union Européenne, Traités de Paris, Rome, Maastricht. Dalloz: Paris, 1996.

CARRAZZA, Roque Antônio. Curso de Direito Constitucional Tributário, $23^{\mathrm{a}}$ Ed. São Paulo: Malheiros, 2007.

CARRAZZA, Roque Antônio. ICMS. 9ª Ed. São Paulo: Malheiros Editores, 2002.

CARREAU Dominique. Droit international. Pédone, 2001.

CARREAU, Dominique. Droit international économique. Paris: Librairie Générale de Droit ET Jurisprudence, 1978.

CARRILLO, SALCEDO J.A. Droit international dê souveraineté dês Etats. RCADI, 1996, vol.257.

CARVAlHO, Aurora Tomazini de. Curso de Teoria Geral do Direito - o Construtivismo Lógico-semântico - 3a . Ed. São Paulo: Noeses, 2013.

CARVALHO, Paulo de Barros. Direito Tributário - Fundamentos Jurídicos da Incidência. 3. ed. rev. e atual. São Paulo: Saraiva, 2004.

CARVAlHO, Paulo de Barros. A Regra-matriz do ICM. Tese de Livre-Docência. São Paulo: PUC, 1981.

CARVAlHo, Paulo de Barros. Curso de Direito Tributário, 26. ed. São Paulo: Saraiva, 2014.

CARVALHO, Paulo de Barros. Direito Tributário, Linguagem e Método. São Paulo: Noeses, 2008.

CARVAlHo, Paulo de Barros; MARTINS, Ives Gandra da Silva. Guerra fiscal: reflexões sobre a concessão de benefícios no âmbito do ICMS. São Paulo: Noeses, 2012. 
CARVALHO, Paulo de Barros. Teoria da Norma Tributária. $5^{\text {a }}$ Ed. São Paulo: Quartier Latin, 2009.

CASELLA, Paulo Borba. Comunidade Europeia e seu ordenamento jurídico. São Paulo: LTr, 1994.

CASELLA, Paulo Barba. MERCOSUL: exigências e perspectivas: integração $e$ consolidação de espaço econômico. São Paulo: LTR, 2006.

CASELLA, Paulo Borba. A integração econômica e seu tratamento constitucional. In: MERCOSUL: desafios a vencer. São Paulo: Conselho Brasileiro de Relações Internacionais (CBRI), 1994. p. 89-101.

CASELLA, Paulo Borba. Direito comunitário no MERCOSUL. Revista dos Tribunais. Cadernos de Direito Constitucional e Ciência Política, v.5, p 235-238, 1997.

CASELLA, Paulo Borba. Internacionalização do direito e impacto da harmonização da legislação no MERCOSUL- o desafio para os profissionais da área jurídica. Revista de Ciências Jurídicas (UCR), V. 10, p. 434-442, 1996.

CASELLA, Paulo Borba. Ordenamento comunitário, direito internacional público, regulamentação do GATT e direito internacional privado. Revista dos Tribunais. Cadernos de Direito Constitucional e Ciência Política, v.1, p. 207-222, 1993.

CASELLA, Paulo Borba; LIQUIDADO, Vera Lúcia (coord.). Direito da Integração. São Paulo: Quartier Latin, 2006.

CASELLA, Paulo Borba. Direito Internacional Tributário Brasileiro: convenções de bitributação. $2^{\mathrm{a}}$ Ed. São Paulo. Ed. Quartier Latin, 2005.

CASELLA, Paulo Borba. União Europeia: instituições e ordenamento jurídico. $2^{\mathrm{a}}$ Ed. São Paulo: LTr, 2002.

CASELLA, Paulo Borba. European Union- MERCOSUR Relations. In: Paulo Canelas de Castro (org.). The European Union 50: Assessing the Past, looking Ahead. 1 ed. Macau, China: Universidade de Macau, 2010, v.1, p. 411-433.

CASELLA, Paulo Borba. Soberania, integração econômica e supranacionalidade. In: Celso D. de A. Mello (Org.). Anuário Direito e Globalização: a soberania. Rio de Janeiro: Renovar, 1999, p. 71-97.

CASELLA, Paulo Borba. Modalidades de harmonização, unificação e uniformização do direito: o Brasil e as convenções interamericanas de direito internacional privado. In: CASELLA, Paulo Borba; ARAUJO, Nadia de (Coords.). Integração jurídica interamericana: as Convenções Interamericanas de Direito Internacional Privado (CIDIPs) e o direito brasileiro. São Paulo: LTr, 1988. p. 77-105. 
CASSONE, Vittorio. A Não-Cumulatividade no Direito Brasileiro e no Direito Italiano. Martins Ives Gandra da Silva (coord.) Caderno de Pesquisas Tributárias $n^{\circ} 10$ - O Princípio da Não- Cumulatividade. São Paulo: Revista dos Tribunais/ Centro de Extensão Universitária, 2004, pp. 422-446

CatalanO, Nicola. Principi di Diritto Comunitário, Milão, 1984, Giuffrè.

Catalano, Nicola. Manuel de droit des Communautés Européennes. Paris: Dalloz et Sirey, 1962.

CELLI JUNIOR, Umberto. A Organização Mundial do Comércio e o Regionalismo do Século XXI. Densidades, v. 9, p. 91-107, 2012.

CELLI JUNIOR, Umberto; CACCIAMALI, Maria Cristina; BOBIK, Marcio. Em busca de uma nova inserção da América Latina na Economia Global. Estudos Avançados (USP. Impresso), v. 26, p. 91-110, 2012.

CELlI JUNIOR, Umberto; TUSSIE, Diana; PEIXOTO, Juliana; SALLES, Marcus. MERCOSUL in the south-south agreements: in the middle of two models of regionalism. Cadernos de Pós-Graduação em Direito - Estudos e Documentos de Trabalho- Faculdade de Direito da USP, v. 2, p. 5-38, 2011.

CELli JUNiOR, Umberto (Org.) MERCADANTE, A. A. (Org.); ARAÚJO, Leandro Rocha (Org.). Blocos Econômicos e Integração na América Latina, África e Ásia. 1'. ed. Curitiba: Juruá, 2006. v. 1.

CETRÁNGOLO, Oscar; JIMÉNEZ, Juan Pablo. Las relaciones entre niveles de gobierno en Argentina. Revista de la CEPAL, Buenos Aires, CEPAL, n. 84, p 117-134, dic. 2004.

CHAMATRÓPULO, M. Pacto Federal para el empleo, la producción y el crecimiento. In: PARADA, Ricardo Antonio; ERRECABORDE, José Daniel (Comp.). Crónica tributaria. Buenos Aires: Errepar, 1994. v. 1.

CHUECA, Sancho; G., Ángel. Los derechos fundalmentales em la Comunidad Europea. Barcelona: Bosch, 1989.

CISNEROS, I., RODRIGUES, J.M., SUZZARINI, A. El Desarrollo del Comercio y las Inversiones entre Brasil y Venezuela. Brasília: Funag, 1998.

CNOSSEN, Sijbren. Paper: VAT Coordination in Common Markets and Federations, Lessons from European Experience, Paper.American Tax Policy Institute, 12 June 2009.

COELHO, Carlos Nayro de Azevedo. Uma Análise Econômica do Imposto sobre o Valor Adicionado no Brasil. Brasília: Comissão de Financiamento da Produção, 1980.

COÊLHO, Sacha Calmon Navarro e DERZI, Misabel Abreu Machado. ICMS- Direito ao Creditamento - Princípio da Não Cumulatividade. Revista Dialética de Direito Tributário, no 102. São Paulo: Dialética, março de 2004, pp. 141-156 
COÊLHO, Sacha Calmon Navarro. Comentários à Constituição de 1988 - Sistema tributário. $7^{\mathrm{a}}$ ed. Rio de Janeiro: Forense, 1998.

COÊLHO, Sacha Calmon Navarro. Curso de direito tributário brasileiro. 8. ed. Rio de Janeiro: Forense, 2005.

COÊLHO, Sacha Calmon Navarro. O IVA Brasileiro. SARAIVA FILHO, Oswaldo Othon; VASQUES, Sérgio; GUIMARÃES, Vasco Branco (org.) IVA para o Brasil Contributos para a Reforma da Tributação do Consumo. São Paulo: Fórum, 2007, pp. 553586.

COÊLHO, Sacha Calmon Navarro. O princípio da legalidade: o objeto da tutela. In PIRES, Adilson Rodrigues; TÔRRES, Heleno Taveira. (Orgs.). Princípios de direito financeiro e tributário: estudos em homenagem ao Professor Ricardo Lobo Torres. Rio de Janeiro: Renovar, 2006. p. 611-632.

COÊLHO, Sacha Calmon Navarro. Tributação indireta e regressividade. In: MACHADO, Hugo de Brito (Coord.). Tributação indireta no direito brasileiro. São Paulo: Malheiros, 2013. p. 396-400.

COMELLI, Alberto. IVA comunitária e IVA nazionale: contributo alla teoria generale dell 'imposta sul valore aggiunto. Padova: Cedam, 2000.

CONSELHO DE IMPOSTOS DA FRANÇA. XIX Relatório ao Presidente da República- Imposto sobre o Valor Agregado. Trad. Por DERZI, Misabel Abreu Machado e LOBATO, Valter de Souza. Revista Internacional de Direito Tributário $\mathrm{n}^{\circ} 2$. Belo Horizonte: Del Rey, julho a dezembro de 2004, PP. 395-598.

CONSTANTINESCO, Leontin-Jean. Tratado de direito comparado: introdução ao direito comparado. Ed. brasileira organizada por Maria Cristina de Cicco. Rio de Janeiro: Renovar, 1998.

CORREIA NETO, Celso de Barros. $O$ avesso do tributo: incentivos e renúncias fiscais no direito brasileiro. Universidade de São Paulo, São Paulo, 2012. 271 p. Tese (Doutorado em Direito Econômico, Financeiro e Tributário). Data da defesa: 18.02.2013.Orientador: Régis Fernandes de Oliveira. Biblioteca Central: O5-20-2

COSCIANI, Cesare. El impuesto al valor agregado. Buenos Aires: Depalma, 1969.

COSTA, Alcides Jorge. ICM na Constituição e na Lei Complementar. São Paulo: Resenha Tributária, 1978.

COSTA, Lígia Maura. OMC: Manual Prático da Rodada Uruguai. São Paulo: Saraiva, 2000 .

COUTO, Jeanlise Velloso. A tributação no Mercosul. In: CASELLA, Paulo Borba; LIQUIDATO, Vera Lúcia Viegas (Coords.). Direito da integração. São Paulo: Quartier Latin, 2006. p. 251-275. 
CRIVELLI, Ernesto. El sistema impositivo de Paraguay desde una perspectiva regional. Departamento de Finanzas del FMI. Washington D.C: FAD, 2010.

CUNHA, Paulo de Pitta e. Integração Europeia. Estudos de Economia, Política e Direito Comunitário, Lisboa, 1993, Imprensa Nacional- Casa da Moeda.

CUNHA, Paulo de Pitta e. De Maastricht a Amesterdão. Problemas da União Monetária Europeia, Coimbra, 1999, Almedina.

CUNHA, Paulo de Pitta e. Estudos de Economia, Política e Direito Comunitários. Lisboa: Imprensa Nacional - Casa da Moeda, 1993. p. 101.

CUNHA, Paulo de Pitta e. Tratado ou Constituição? In: CUNHA, Paulo de Pitta e; QUADROS, Fausto de (Orgs.). Uma Constituição para a Europa. Instituto Europeu da Faculdade de Direito de Lisboa, British council, Goethe-Institut Lissabon, Institut FrancoPortugais. Coimbra: Almedina, 2004. p. 45-9.

DAILLIER, P. et PELLET, A. Droit international public. LGDJ, 1999.

DANIELE, Luigi. Il Diritto Materiale della Comunità Europea. Introduzione allo studio del mercato interno e delle politiche comunitarie. $3^{\text {a }}$ Edição, Milano, 2000, Giuffrè editore.

DAVID, René. Los grandes sistemas juridicos contemporáneos: derecho comparado. Traducción de la 2. edición francesa por Pedro Bravo Gala. Madrid: Aguilar, 1969.

DAVID, René. Traité élémentaire de droit civil comparé. Paris: Librairie Générale de Droit du Jurisprudence, 1950.

DAVID, René. Tratado de derecho civil comparado: introducción al estudio de los derechos extranjeros y al método comparativo. Traducción de Javier Osset. Madrid: Revista de Derecho Privado, 1953.

DELUCA, Santiago. El Mercosul necessita su Maastricht. Revista Pensar En Derecho, nº1, Año 1. Editorial Universitaria de Buenos Aires, Ciudad de Buenos Aires: 2012.

DERZI, Misabel Abreu Machado e COÊLHO, Sacha Calmon Navarro. ICMS- Direito ao Creditamento - Princípio da Não-Cumulatividade. Revista Dialética de Direito Tributário, $\mathrm{n}^{\circ}$. 102. São Paulo: Dialética, março de 2004, pp. 141-156.

DERZI, Misabel Abreu Machado e SANTIAGO, Igor Mauler. A Harmonização dos IVAS no Brasil para o Desenvolvimento Produtivo. SARAIVA FILHO, Oswaldo Othon de Pontes; VASQUES, Sérgio; GUIMARÃES, Vasco Branco (Org.). IVA para o Brasil: contributos para a reforma da tributação do consumo. Belo Horizonte: Fórum, 2007. p. 527-551.

DERZI, Misabel Abreu Machado. A Necessidade da Instituição do IVA no Sistema Constitucional Tributário Brasileiro. BALTHAZAR, Ubaldo César (or.). Reforma Tributária e MERCOSUL - a Instituição do IVA NO Direito Brasileiro. Belo Horizonte: Del Rey, 1999. pp. 17-30. 
DERZI, Misabel Abreu Machado. Construindo o Direito Tributário na Constituição Uma análise da Obra do Ministro Carlos Mario Velloso. Belo Horizonte: Del Rey, 2004.

DERZI, Misabel Abreu Machado. Direito tributário aplicado. Belo Horizonte: Del Rey, 1997.

DERZI, Misabel Abreu Machado. Modificações da Jurisprudência no Direito Tributário. São Paulo: Noeses, 2009.

DERZI, Misabel de Abreu Machado. Tipo ou conceito no direito tributário. Revista da Faculdade de Direito da Universidade Federal de Minas Gerais, Belo Horizonte, v. 31, n. 30/31, p. 213-260, 1987/1988.

DEVESA, Jaime. IVA - Código do Imposto sobre o Valor Acrescentado. Coimbra, Portugal: Livraria Almedina, 2003.

DUARTE, Maria Luísa. Direito da União Europeia e das Comunidades Europeias, volume I, tomo I, Lisboa, 2001, Lex.

DUE, John F. Indirect Taxation in Developing Economies. Baltimore, London: Hohns Hopkins, 1970.

DUE, John F. Tributação indireta nas economias em desenvolvimento. São Paulo: Perspectiva, 1974.

DUPUY, P.M. Droit international public. Dalloz, 2000.

DUPUY, René-Jean. O direito internacional. Coimbra : Ed. Almedina, 1993.

EBRILL, Liam; KEEN, Michael; BODIN, Jean- Paul; SUMMERS, Victoria. The Modern VAT. Washington: International Monetary Fund, 2001

EGRET, Georges. La TVA. Paris: Presses Universitaires de France, 1978. 128 p. - (Que sais - je?).

EHLERMANN, C. D. The internal market following the Single European Act. Comom Market Law Review, vol. 24, n. 3, 1987, pgs 361-409.

ENGLISCH, Joachim. Fundamental principles of Value Added Tax (VAT), Universität Augsburg, 2009.

FALCÃO, Amílcar. Fato gerador da obrigação tributária. $6^{a}$ ed. Rio de Janeiro: Forense, 1994.

FALCÃO, Maurin Almeida. A tríplice convergência dos sistemas tributários. Revista de Direito Internacional Econômico e Tributário, v. 1, n. 2, p. 181-205, jul./dez. 2006.

FALCÃO, Maurin Almeida. Mecanismos para facilitação do processo de integração econômica: a formação de zonas tributárias. Revista de Direito Internacional, Econômico e Tributário da Universidade Católica de Brasília, n. 3, p. 254-270, 2008. 
FALLON, Marc- Droit Matériel general des Communautés Européennes, Lou-vain-laNeuve, 1997, Bruylant- Academie.

FAZIO, Silvia. Contratos Internacionais na União Europeia e no MERCOSUL. São Paulo: LTR, 1998.

FERNANDES, Edison Carlos. Sistema tributário do MERCOSUL: o processo de harmonização das legislações tributárias. $3^{\mathrm{a}}$ ed. São Paulo: Editora Revista dos Tribunais, 2001.

FERNANDES, Edison Carlos. Normas tributárias no Mercosul. In: MARTINS, Ives Gandra da Silva (Coord). O direito tributário no Mercosul. Rio de Janeiro: Forense, 2000. p. 177-220.

FERREIRO LAPATZA, José Juan. Direito Tributário. Teoria Geral do Tributo. Barueri: Manole; Madrid: Marcial Pons, 2007.

FONTAINE, Pascal. A Construção Europeia de 1945 aos Nossos Dias. Lisboa: Gradiva, 1998.

FONTAINE, Pascal. La Europa de los ciudadanos. Luxemburgo: Oficina de Publicaciones Oficiales de las Comunidades Europeas, 1994.

FONTAINE, Pascoal. Comprendre les politiques de l'Union européenne: 12 leçons sur l'Europe. Luxembourg: Office des publications de l'Union européenne, 2014.

FOUCAULD, Jean-Baptiste de. Les effets économiques d'une hausse de la TVA. Impôts et reforme fiscale: Cahiers français 274, p. 23, 1996.

GALLO, Franco; MELIS, Giuseppe. L'elusione fiscale internazionale nei processi di integrazione tra stati: 1'esperienza delle Comunità Europea. In: Congresso Internacional de Direito Tributário de Vitória. Justiça tributária: direitos do fisco e garantias dos contribuintes nos atos da administração e no processo tributário. São Paulo: Max Limonad, 1998. p. 165-202.

GARCIA JÚNIOR, Armando Álvares. ALCA - Área de Livre Comércio das Américas. Aduaneiras, 2003.

GENTILI, Alberico- O Direito de Guerra, Ed. Unijuí, 2005.

GIANNATTASIO, Arthur Roberto Capella. A integração como fenômeno jurídicopolítico: uma leitura sobre a construção histórica da CECA. São Paulo, 2013. 2v., 885 p. Tese (Doutorado em Direito Internacional). Data de defesa: 27.09.2013. Orientador: Paulo Borba Casella. Biblioteca Central: R 14-10-36 (v.1). Biblioteca Central: R14-10-37 (v.2).

GIANNINI, Achille Donato. I concetti fondamentali del diritto tributario. Torino: Torinese, 1956. 
GOMES, Joséli Fiorin. Dificuldades à ampliação da integração regional: um estudo a partir da complexa uniformização jurídica em matéria de direito do consumidor na União Europeia e no Mercosul. Revista de la Secretaría del Tribunal Permanente de Revisión, Asunción, Paraguay, año 1, n. 2, p. 151-169, ago. 2013.

GÓMEZ SABAINI, Juan Carlos; GAGGERO, Jorge A. Lineamientos para una reforma del sistema tributario Argentino. Proyecto PNUD ARG 93/009/CITAF-OEA, CITAF, $\mathrm{n}^{\circ}$. T-37, Buenos Aires: Centro Interamericano de Tributación y Administración Financiera (CITAF), 1997.

GONÇALVES, Maria Eduarda. O tratado de Nice e o futuro da Europa. Áreas Editora, 2001 .

GONZÁlez, Gustavo; MONTERO, Marcelo, OLMOS, Leticia e PELÁEZ, Fernando. Un diseño de IVA personalizado. Focalización de benefícios fiscales de acuerdo a la capacidad contributiva. Revista Jornadas Tributarias, Montevideo, p. 1-46, 2011.

GOODE, Walter. Dictionary of Trade Policy Terms. Fourth Edition. Cambridge University Press: Cambridge, United Kingdom, 2003.

GOUVEIA, Jorge Bacelar. Textos Fundamentais de Direito Internacional. Lisboa: Editorial Notícias, 2000.

GOYOS Júnior, DURVAL de Noronha. GATT, MERCOSUL \& NAFTA. $2^{\text {a }} 167 \mathrm{P}$. São Paulo: Observador Legal Editora, 1996.

GRAU, Eros Roberto. Ensaio e Discurso sobre a Interpretação/Aplicação do Direito. 2. ed. São Paulo: Malheiros, 2003.

GRIZIOTTI, Benvenuto. Principios de Ciencia de las Finanzas. Buenos Aires: Depalma, 1959.

GUARDIA, Rodrigo Medeiros. A regra-matriz de incidência das normas jurídicas como diagrama semiótico. Cognitio-Estudos: Revista Eletrônica de Filosofia, São Paulo, CEP/PUC-SP, v. 8, n. 2, p. 106-119, jul./dez. 2011.

GUEDES, Josefina M. M. Antidumping, Subsídios e Medidas Compensatórias. Aduaneiras, 2003.

GUIMARÃES, Samuel Pinheiro. ALCA e MERCOSUL. Riscos e oportunidades para o Brasil. Brasília: IPRI- FUNAG, 2002.

GUIMARÃES, Vasco Branco. A Tributação do Consumo no Brasil - uma Visão Europeia. In: SARAIVA FILHO, Oswaldo Othon; VASQUES, Sérgio: GUIMARÃES, Vasco Branco (org.) IVA para o Brasil : Contributos para a Reforma da Tributação do Consumo. Belo Horizonte: Fórum, 2007

HABERFELD, Sérgio (ORG.). ALCA : Riscos e Oportunidades. Barueri: Manole, 2003. 
HABERMAS, Jürgen. A constelação pós-nacional: ensaios políticos. São Paulo: Littera Mundi, 2001.

HABERMAS, Jürgen. O estado-nação europeu frente aos desafios da globalização: o passado e o futuro da soberania e da cidadania. Nos Estudos CEBRAP, São Paulo, n. 43, p. 87-101, nov.1995.

HARTLEY, Trevor. The Foundations of European Community Law: An Introduction to the Constitutional and Administrative Law of the European Community. Oxford:1998, Oxford University Press.

HILF, Meinhard. Os direitos fundamentais na Constituição Europeia. In: CUNHA, Paulo de Pitta e; QUADROS, Fausto de (Orgs.). Uma Constituição para a Europa. Instituto Europeu da Faculdade de Direito de Lisboa, British council, Goethe-Institut Lissabon, Institut Franco-Portugais. Coimbra: Almedina, 2004. p. 179- 188.

HOBSBAWN, Eric J. Era dos extremos: o breve século XX: 1914-1991. 2. ed., 30. reimpr. Tradução de Marcos Santarrita. São Paulo: Companhia das Letras, 1995.

JARACH, Dino. Curso superior de derecho tributario. Ed. actualizada. Buenos Aires: Liceo Profesional CIMA, 1969.

JIMÉNEZ DE ARÉCHAGA, Eduardo. El derecho internacional contemporáneo. Madrid: Technos, 1980.

JUSTIÇA TRIBUTÁRIA- I Congresso Internacional de Direito Tributário. Ed. Max Limonad: 1998.

KANT, Immanuel. À paz perpétua e outros opúsculos. Lisboa, Portugal: Edições 70.

KELSEN, Hans. Teoria Geral do Direito e do Estado, $4^{\mathrm{a}}$ Ed. Trad. Por BORGES, Luís Carlos. São Paulo: Martins Fontes, 2005.

KUNZLER, Jacob Paulo. MERCOSUL e o Comércio Exterior. Aduaneiras, 2003.

LIMA, Emanuel Vidal. IVA - Imposto sobre o Valor Acrescentado. 9 ${ }^{\text {a }}$ Ed. Porto: Porto Editora, 2003.

LAFER, Celso. O cenário mundial e o relacionamento União Europeia- MERCOSUL, p. 88-91, in Política Externa, vol. 9, nº 1, junho-julho de 2000.

LAFER, Celso. Sentido estratégico do MERCOSUL. In: MERCOSUL: desafios a vencer. São Paulo: Conselho Brasileiro de Relações Internacionais, 1994, p. 9-11.

LAMBERT, Édouard. La fonction du droit civil comparé: introduction Paris: V. Giard \& E. Briere, 1903.

LANDMANN, Eve Rimoldi de. Futuro de la integración en la nueva civilización. Revista de la Secretaría del Tribunal Permanente de Revisión, Asunción, año 1, n. 2, p. 113-127, 2013. 
LAIRES, A. Campos. IVA- primeiro passo de uma reforma. Revista da Administração Pública, nº 32: ADPP 1986.

LAURÉ, Maurice. Tratado de politica fiscal. Madrid: Ed. Derecho Financiero, 1969.

LAURÉ, Maurice. La taxe sur la valeur ajoutée. Paris: Sirey, 1953.

LEITE, Isabel Costa. Construção europeia: um processo supranacional ou intergovernamental? Anais do IV Congresso da Associação Portuguesa de Ciência Política, Lisboa, de 7 de março de 2008.

LENAERTS, Koen; ARTS, Dirk; BRAY, Robert. Procedural Law of the European Union, London, 1999, Sweet \& Maxwell.

LIMPENS, Anne. Harmonisation des législations dans le cadre du marché common. Revue International de Droit Comparé, v. 19, n. 3, p. 621-653, juil./sept. 1967.

LIQUIDATO, Vera Lúcia Viegas. Teoria da harmonização jurídica: alguns esclarecimentos. Novos Estudos Jurídicos, v. 9, n. 3, p.617-655, set./dez. 2004.

LIPO, Luiz Francisco e MELO, José Eduardo Soares de. A Não Cumulatividade Tributária (ICMS, IPI, ISS, PIS e COFINS), 2ª Ed. São Paulo: Dialética, 2004.

LOUSA, Maria dos Prazeres. Algumas considerações sobre a adoção do IVA comunitário. Separata do Boletim do Ministério da Justiça nº e Ciência e Técnica Fiscal, nº 247/249.

MATIOS, Aroldo Gomes. ICMS - Comentários à LC 87/96. São Paulo: Dialética, 1997.

MACEDO, José Alberto Oliveira. Conflitos de competência na tributação do consumo. Universidade de São Paulo, São Paulo, 2013. 161 p. Tese (Doutorado em Direito Econômico, Financeiro e Tributário). Data de defesa: 10.06.2013. Orientador: Paulo Ayres Barreto.

MACHADO, Hugo de Brito (coord.). Tributação indireta no direito brasileiro. São Paulo: Malheiros, 2013.

MACHADO, Hugo de Brito. Virtudes e Defeitos da Não-Cumulatividade no Sistema Tributário Brasileiro. MARTINS, Ives Gandra da Silva ( coord.). Caderno de Pesquisas Tributárias $\mathrm{n}^{\circ}$ 10- O Princípio da Não- Cumulatividade. São Paulo: Revisa dos Tribunais/ Centro de Extensão Universitária, 2004 , pp. 68-104.

MACHADO, Raquel Cavalcanti Ramos. Competência tributária entre a rigidez do sistema e a atualização interpretativa. Universidade de São Paulo, São Paulo, 2013. 278 p. Tese (Doutorado em Direito Econômico, Financeiro e Tributário). Data de defesa: 1.05.2013. Orientador: Luis Eduardo Schoueri. Biblioteca Central: R6-10-35.

MARTINS, Ives Gandra da Silva (Coord.). O Direito Tributário no MERCOSUL. Rio de Janeiro: Forense, 2000. 
MARTINS, Ives Gandra da Silva. O Sistema Tributário na Constituição. $6^{\mathrm{a}}$ Ed. São Paulo: Saraiva, 2007.

MARTINS, Ives Gandra da Silva. Tributação no MERCOSUL. São Paulo: Editora Revista dos Tribunais: Centro de Extensão Universitária, 2002.

MARTINS, Ives Gandra da Silva. O direito tributário no MERCOSUL. Rio de Janeiro: Forense, 2000.

MARTINS, Ives Gandra da Silva. O Princípio da Não-Cumulatividade e os Princípios da Subvenção Pública e da Neutralidade. In:MACHADO, Hugo de Brito (Coord.). NãoCumulatividade Tributária. São Paulo: Dialética; Fortaleza: ICET, 2009, pp. 241 - 252.

MATTERA, Alfonso. El Mercado Único Europeo: sus reglas, su funcionamiento. Madri: Cívitas, 1991.

MATTERA, Alfonso. L'harmonisation des législations nationales: instrument d'intégration et de reconnaissance mutuelle, in Revue du Droit de l'Union européenne (ciaprès: RDUE) 4/2010.

MATTERA, Alfonso. La reconnaissance mutuelle: une valeur historique ancienne, un principe juridique intégrationniste, l'assise politique d'un modèle de société humaniste, in RDUE 3/2009.

MATTERA, Alfonso. La libera circolazione delle merci all'interno della Comunità, in Novissimo Digesto, UTET - Torino 1980.

MATTOS, Adherbal Meira. Apresentação. In: CASELLA, Paulo Borba; LIQUIDATO, Vera Lúcia Viegas (Coords.). Direito da integração. São Paulo: Quartier Latin, 2006. p. 15.

MAZOWER, Mark. $O$ continente das trevas: o século XX na Europa. Coimbra: Edições 70, 2014.

MAZZ, Addy. ¿Estatuto del contribuyente o revisión del Código Tributario y normas generales para su adecuación a la normativa constitucional? Revista Tributaria, Montevideo, Instituto Uruguayo de Estudios Tributarios, v. 36, n. 212, p. 771-818, set./oct. 2009.

MELO, José Eduardo Soares de. Contribuições sociais no sistema tributário. 4. ed. rev., atual. e ampl. São Paulo: Malheiros, 2003.

MEIRA MATOS, Adherbal. Direito internacional público. Rio de Janeiro: Renovar, 1996.

MEIRELLES, José Ricardo. Impostos indiretos no MERCOSUL e integração. São Paulo: LTr,2000.

MELLO, Celso D. de Albuquerque. Curso de direito internacional público. $13^{\mathrm{a}} \mathrm{ed}$. Rio de Janeiro: Renovar, 2001. 
MELLO, Celso D. de Albuquerque. Curso de Direito Internacional Público. Renovar, (2 volumes), 2002.

MELO, José Eduardo Soares de; BOTTALLO, Eduardo Domingos. Comentários às Súmulas Tributárias do STF e do STJ. São Paulo: Quartier Latin, 2007.

MELO, José Eduardo Soares de. A não-cumulatividade tributária. São Paulo: Dialética, 1998.

MENEZES, Wagner. O Direito Internacional temas e perspectivas globais. Revista Jurídica Consulex, v. xv, p. 26-28, 2012.

MENEZES, Wagner. Tratados Normativos no MERCOSUL e sua Aplicação pelo Direito Brasileiro. Anais do X Encontro de Estudantes do MERCOSUL, Londrina Pr., v. 01, n. 01, p. 1070-1078, 2002.

MENEZES, Wagner. MERCOSUL: Desenvolvimento Institucional e o Direito da Integração. Direito da Integração Direitos Humanos no Século XXI, Curitiba - Pr., v. 01, n. 01, p. 125-165, 2002.

MENEZES, Wagner. MERCOSUL 10 Anos: Desenvolvimentos Institucional e o Direito da Integração. Direito da Integração e Relações Internacionais ALCA MERCOSUL e União Europeia. Florianópolis - SC., v. 01, n. 01, p. 683-701, 2001.

MENEZES, Wagner. Lineamento para Sistematização do Estudo do Direito da Integração. Editora Revista dos Tribunais, São Paulo - SP., v. 773, nº. 01, p. 52-73,

MENEZES, Wagner. Direito Comunitário. Revistas dos Tribunais, São Paulo - SP, v. 778, n. 02, p. 733-752, 2000.

MENEZES, Wagner. O Direito Comunitário MERCOSUL - Uma visão crítica. MERCOSUL no Cenário Internacional, Direito e Sociedade, Curitiba - Pr., v. 02, n. 01, p. 137-159, 1999.

MERCADANTE, Araminta de Azevedo; CELLI JUNIOR, Umberto; ARAÚJO, Leandro Rocha de (Orgs.). Blocos econômicos e integração na América Latina, África e Ásia. Curitiba: Juruá, 2006. v. 1.

MINIUCI FERREIRA JR., Geraldo. O direito internacional, o projeto de integração europeia e a crise na zona do euro: e agora?. Revista Jurídica Consulex, Brasília, p. 3435, 15 de agosto de 2012.

MIRANDA, Jorge. Direito internacional público. Lisboa: Pedro Ferreira, 1995.

MONACO, Gustavo Ferraz de Campos. A globalização entre o passado e o presente da soberania. Revista da Faculdade de Direito do Sul de Minas, v. extra, p. 45-53, 2008.

MONACO, Gustavo Ferraz de Campos. Da qualificação e hierarquia do direito comunitário pela justiça constitucional portuguesa e pelo Tribunal de Justiça das 
comunidades europeias. Revista da Faculdade de Direito. Universidade de São Paulo, v. 101, p. 777-812, 2006.

MONACO, Gustavo Ferraz de Campos. A União Europeia, os Estados e as regiões: em busca da coesão econômica e social por meio de uma política regional - aspectos jurídicos. Revista Alfa de Direito, v. 1, p. 239-263, 2005.

MONACO, Gustavo Ferraz de Campos. Estática e dinâmica do direito dos tratados: abordagem a partir do direito internacional tributário. In: MONACO, Gustavo Ferraz de Campos; SILVA, Iran José de Oliveira da; FERREIRA, Iris Estevez; NERY, João Elias; RIBEIRO, Marcélio José; MELO, Otávio Augusto de. (Org.). Antologia Thesis. 1 ed. São Paulo: Associação João Meinberg de Ensino de São Paulo, 2006, v. 1, p. 139-171.

MONACO, Gustavo Ferraz de Campos; JUBILUT, Liliana Lyra. Direito Internacional Público. 1. ed. São Paulo: Lex Editora, 2010. v. 1.

MONACO, Gustavo Ferraz de Campos; RODAS, João Grandino. Conferência da Haia de Direito Internacional Privado: a participação do Brasil. 1. ed. Brasília: Fundação Alexandre de Gusmão, 2007. v. 1.

MONACO, Riccardo. Comparaison et rapprochement des législations dans le marché commun européen. Revue Internationale de Droit Comparé, v. 12, n. 1, p. 61-74, janv./mars 1960.

MONACO, Riccardo. Le rapprochement des législations nationales dans le cadre du marché commun. Annuaire français de Droit International, v. 3, p. 558-568, 1957.

MONNET, Jean. Memórias: a autobiografia de um dos pais fundadores da União Europeia. Tradução de Alexandra Costa e Sousa e Nuno Fonseca. Lisboa: Ulisseia, 2006.

MOREIRA, André Mendes. A tributação dos serviços de comunicação. São Paulo: Dialética, 2006.

MOREIRA, André Mendes. A não- cumulaividade dos tributos. São Paulo: Noeses, 2012.

MOURA RAMOS, Rui Manuel. Das Comunidades à União Europeia. Coimbra: Coimbra Editora, 1999.

MUSGRAVE, Richard A. El futuro de la política fiscal. Madrid:Instituto de Estúdios Económicos, 1980.

NAKADA, Minoru. A OMC e o Regionalismo. São Paulo: Aduaneiras, 2002.

NAKAYAMA, Juliana Kiyosen. Reforma tributária - MERCOSUL e União Europeia. Curitiba: Juruá, 2003.

NEUMARK, Fritz. Rapport du Comitê Fiscal et Financier Bruxelles: Comission Communauté Economique Européenne, 1962. 
NOGUEIRA, Ruy Barbosa. Curso de Direito Tributário, $10^{\mathrm{a}}$ ed. São Paulo: Saraiva, 1990.

NOGUEIRA, Ruy Barbosa. Direito Tributário Comparado. São Paulo: Saraiva, 1971.

NORMATIVA. Impuesto sobre el Valor Anãdido. 12a ed. España. Centro de Estudios Financieros, 2003.

NORONHA GOYOS JR, Durval. OMC e os Tratados da Rodada do Uruguai. São Paulo: Aduaneiras, 2003.

OCDE. Impôts et activité économique: Les impôts sur la consummation. Impôts et reforme fiscal: Cahiers français 274, 1996, p. 21-23

OGLEY, Adrian. Principles of Value Added Tax - a European Perspective. London: Interfisc Publishing, 1998.

ORIVE, Alfaro Gascón. IVA práctico. $8^{\mathrm{a}}$ ed. Centro de Estudios Financieros: 2003.

PATRUNO, M.. Manuale di Diritto della Comunità Europea. Universita Edizioni - CxT, $3^{\text {a }}$ edizione, 1998.

PALMA, Clotilde Celorico. A harmonização comunitária do imposto sobre o valor acrescentado- Quo Vadis? Revista de Ciências Empresariais e Jurídicas, nº . 5. 2005.

PALMA, Clotilde Celorico. Introdução ao Imposto sobre o Valor Acrescentado. Coimbra: Almedina, 2004.

PANEBIANCO, Massimo. L'organizzazione internazionale regionale. In: BAPTISTA, Luiz Olavo; FONSECA, José Roberto Franco da (Coords.). $O$ direito internacional no terceiro milênio: estudos em homenagem ao professor Vicente Marotta Rangel. São Paulo: LTr, 1998. p. 194-213.

PAPARELLA, Franco. L'armonizzazione del sistema tributario nazionale: rispetto al diritto tributario europeo: l'esperienza italiana. Revista Internacional de Direito Tributário, Belo Horizonte, Associação Brasileira de Direito Tributário (ABRADT); Del Rey, v. 5, p. 3-31, jan./jun. 2006.

PAULSEN, Leandro. Impostos: federais, estaduais e municipais. 4. ed. rev. atual. Porto Alegre: Livraria do Advogado, 2008.

PEREIRA, André Gonçalves, QUADROS, Fausto de. Manual de direito internacional público.Coimbra: Almedina, 2002.

PEREIRA, Gil Fernandes. Ordenação explicativa e contabilização do IVA. $7^{\mathrm{a}}$ ed. revista e actualizada. Coimbra, Portugal, 2003.

PERRONE-MOISÉS, Claudia. Bobbio e a teoria política na lição dos clássicos. CULT, São Paulo, p. 57 - 59, 01 jul. 2006. 
PESCATORE, Pierre. L'ordre juridique dês Commuautés Européennes. Étude des sources du droit communautaire. Presses Universitaires de Liège: Liège: 1975.

PETTIT, Horacio Antonio. Legislación tributaria. Asunción, Paraguay: Intercontinental, 2008.

PIETRO, Adriano. Lo stato della fiscalità nell'Unione europea. L'esperienza e l'efficacia dell'armonizzazzione, t. I e II, Università de Bologna, Alma Mater Studiorum, 2003.

PINTO, Miguel Silva. Imposto sobre o Valor Acrescentado IVA. $7^{\mathrm{a}}$ ed. Lisboa: Áreas Editora, 2002.

PINTO, Miguel Silva. IVA. Exercícios práticos resolvidos. $2^{\mathrm{a}}$ ed. Lisboa: Áreas Editora, 2003.

PIPKORN, Jörn. Les méthodes de rapprochement des législations à l'intérieur de la CEE. In: BOUREL, Pierre at al. L'influence des Communautés Européennes sur le droit international privé des États membres. Bruxelles: F. Larcier; Institut Universitaire International, 1981. p. 13-48.

PIRES, Francisco Lucas. Introdução ao direito constitucional europeu: seu sentido, problemas e limites. Coimbra: Almedina, 1997.

PORTO, Alberto. Federalismo fiscal: el caso argentino. Buenos Aires: Editorial Tesis; Instituto Torcuato di Tella, 1990.

PORTO, Manuel Carlos Lopes. Teoria da Integração e Políticas Comunitárias Face aos Desafios da Globalização. Almedina,Coimbra, Portugal, 2002.

PRESMAN, Jorge Alberto. La coparticipación de impuestos: del federalismo fiscal a centralismo menemista. Buenos Aires: Centro de Estudios para el Cambio Estructural (CECE), 1992. (Estudios. n. 5).

QUADROS, Fausto de. Direito das Comunidades Europeias e Direito Internacional Público.Coimbra: Almedina, 1991.

QUADROS, Fausto de. Direito da União Europeia.Coimbra: Almedina, 2013.

QUADROS, Fausto de. Prefácio. In: VILHENA, Maria do Rosário. O princípio da subsidiariedade no direito comunitário. Lisboa: Almedina, 2002.

RAMOS, Rui Manuel Moura. Das Comunidades à União Europeia. Estudos de Direito Comunitário, $2^{a}$ edição, Coimbra, 1999, Coimbra Editora.

RAMOS, Rui Manuel Moura. Direito Comunitário (programa, conteúdos e métodos de ensino). Coimbra Editora: Coimbra, 2003.

RANGEL, Vicente Marotta. Direito e relações internacionais. São Paulo: Revista dos Tribunais, 1993. 
RIBEIRO, José Antunes. Lei geral tributária -comentada e anotada e legislação complementar. Lisboa: Quid Juris? Sociedade Editora, 2003.

RIDEAU, Joel - Droit Institutionnel de l'Union ET dês Communautés Européennes, $3^{\mathrm{a}}$ edição, Paris, 1999, L.G.D.J.

ROCHA, Valdir de Oliveira. ICMS - Problemas jurídicos. São Paulo: Dialética, 1996.

ROCHA, Valdir de Oliveira. O ICMS e a LC 87/96. São Paulo: Dialética, 1997.

RODAS, João Grandino. Contratos internacionais. São Paulo: Revista dos Tribunais, 2002.

RODRÍGUEZ DO AMARAL, Antonio Carlos. Imposto sobre o valor agregado- IVA = Value Added Tax : Brasil, Mercosul, União Europeia. São Paulo : ABDT/Rumo, 1995.

ROUSSEAU, Charles. Droit international public. Paris: Dalloz, 1984.

RUIZ, Nuno. O princípio da subsidiariedade e a harmonização de legislações na Comunidade Europeia. In: CUNHA, Paulo de Pitta e et al. A União Europeia na encruzilhada. Coimbra: Almedina, 1996. p. 129-138.

SACCO, Rodolfo. Introdução ao direito comparado. Tradução de Véra Jacob de Fradera. São Paulo: Revista dos Tribunais, 2001.

SAINZ DE BUJANDA, Fernando. Lecciones de derecho financeiro, $6^{\mathbf{a}}$ Ed. Madrid: Facultad de Derecho Universidad Complutense, 1998.

SÁNCHEZ, Angel Sanchez. El impuesto sobre el valor añadido en las operaciones intracomunitarias. $2^{\mathrm{a}}$ ed. Espanha: Ediciones Deusto, 2002.

SANZ, Xavier G. y MUÑOZ, Josep I. Fuentes de información en internet para el estudio del derecho internacional público y las relaciones Internacionales. Revista Espanõla de Derecho Internacional, Vol. XLIX, nº.. 2, 1999.

SANTIAGO, Igor Mauler. A harmonização das legislações tributárias no Mercosul. Revista do CAAP, Belo Horizonte, Centro Acadêmico Afonso Pena, UFMG, v. 2, n. 2, p. 133-152, 1996/1997.

SCHMITT, Carl. O conceito do político; Teoria do partisan. Coordenação e supervisão de Luiz Moreira; tradução de Geraldo de Carvalho. Belo Horizonte: Del Rey, 2009.

SCHMÖLDERS, Günter: Ideali tributari o tributi ideali? Rivista di Diritto Finanziario e Scienza delle Finanze, 1957, p. 427-429.

SCHOUERI; Luis Eduardo. Direito Tributário. $3^{\circ}$ Edição - São Paulo: Saraiva, 2013.

SCHOUERI, Luís Eduardo. Considerações sobre os rumos do sistema tributário. Digesto Econômico, v. 461, p. 54-69, 2010. 
SCHOUERI, Luís Eduardo. Merging markets in the new economic order: international tax issues. In: Relatório do III Congresso Brasileiro de Direito Tributário Internacional do IBDT. Direito Tributário Atual, v. 23, p. 7-10, 2009.

SCHOUERI, Luís Eduardo. As tendências do Direito Tributário Internacional (Relatório do II Congresso de Direito Tributário Internacional do IBDT). Direito Tributário Atual, v. 21, p. 7-11, 2007.

SCHOUERI, Luís Eduardo. Questões Atuais da Tributação e da Cooperação Internacionais. Revista de Direito Tributário Internacional, São Paulo, v. 2, p. 49-77, 2006.

SCHOUERI, Luís Eduardo. Tributação direta e direito comunitário europeu em relação a terceiros países. Direito Tributário Atual, v. 20, p. 125-165, 2006.

SCHOUERI, Luís Eduardo. Tratados e Convenções Internacionais sobre Tributação. Direito Tributário Atual, v. 17, p. 20-49, 2003.

SCHOUERI, Luís Eduardo. Harmonização Tributária no Mercosul. Revista Direito Mackenzie, São Paulo, v. 2, ano 1, p. 171-178, 2000.

SCHOUERI, Luís Eduardo. Princípio da fonte no direito internacional tributário. In: Ricardo Lobo Torres; Eduardo Takemi Kataoka; Flavio Galdino. (Org.). Dicionário de princípios jurídicos. Rio de Janeiro: Elsevier, 2010, v. , p. 477-485.

SESSA, Giuseppe. L'Imposta sul valore aggiunto. Roma: Bulzoni, 1971.

SILVA FILHO, Antônio Rodrigues. Harmonização tributária no MERCOSUL. $2^{\mathrm{a}}$ ed. atual. São Paulo: Aduaneiras, 2001.

SILVA, Roberto Luiz (Coord.). O Brasil e os acordos econômicos internacionais: Perspectivas jurídicas e econômicas à luz dos acordos com o FMI. São Paulo: RT, 2003.

SILVA, Roberto Luiz. Direito Econômico Internacional e Direito Comunitário. Editora Del Rey, 2000.

SILVA, Roberto Luiz. Globalização e regionalismo no cenário da nova ordem internacional. Revista da Faculdade de Direito da UFMG, n. 55, p. 141-166, jul./dez. 2009.

SIMÓN, Jorge Hernán. Sustitución del impuesto sobre los ingresos brutos: trade off entre eficiencia económica y autonomía provincial. Rosário: UNR Editora. Editorial de la Universidad Nacional de Rosario, 2001.

SMITH, Adam. A riqueza das nações, v. II. São Paulo: Martins Fontes, 2003.

SOARES, António Goucha. A carta dos direitos fundamentais da União Européia: a proteção dos direitos fundamentais no ordenamento comunitário. Coimbra: Coimbra Editora, 2002. 
SOARES, Mário Lúcio Quintão. Mercosul: direitos humanos, globalização e soberania. 2. ed. rev., atual. e ampl. Belo Horizonte: Del Rey, 1999.

SOARES, Mário Lúcio Quintão. Direitos fundamentais e direito comunitário: por uma metódica de direitos fundamentais aplicada às normas comunitárias. Belo Horizonte: Del Rey, 2000.

SOUZA, Rubens Gomes de. Os impostos sobre o valor acrescido no sistema tributário. Revista de Direito Administrativo, no 110, p. 17-26, 1972.

SOUZA, João Ricardo Carvalho de. Constituição Brasileira e Tribunal de Justiça do MERCOSUL. Curitiba: Juruá, 2001.

STELGES, Isabela Kathrin. A cidadania da União Europeia:uma sugestão para o MERCOSUL. Belo Horizonte: Del Rey, 2002.

TANZI, Vito. Taxation in an Integrating World. Washington: The Brookings Institution, 1995. $168 \mathrm{p}$.

TEIXEIRA, Alessandra Machado Brandão. A tributação sobre o consumo de bens $e$ serviços. Belo Horizonte: Mandamentos, 2002.

TERRA, Ben; KAJUS, Julie. A Guide to the European VAT Directives. IBFD Publications. BV, 2010.

THORSTENSEN, Vera. OMC - As Regras do Comércio Internacional e a Nova Rodada de Negociações Multilaterais. Aduaneiras, 2003.

TIPKE, Klaus; LANG, Joachim. Direito Tributário (Steuerrecht): Volume I. Tradução: Luiz Dória Furquim. Ed. Safe, São Paulo, 2008.

TIPKE, Klaus; LANG, Joachim. Direito Tributário (Steuerrecht) : Volume II. Tradução: Luiz Dória Furquim. Ed. Safe, São Paulo, 2013.

TIPKE, Klaus; YAMASHITA, Douglas. Justiça fiscal e princípio da capacidade contributiva. Malheiros, São Paulo, 2002.

TOMÉ, Fabiana Del Padre. A prova no direito tributário. 3. ed. rev. São Paulo: Noeses, 2013.

TORRES, Heleno Taveira. O IVA na Experiência Estrangeira e a Tributação das Exportações no Direito Brasileiro. SARAIVA FILHO, Oswaldo Othon; VASQUES, Sérgio: GUIMARÃES, Vasco Branco ( org. ) IVA para o Brasil - Contributos para a Reforma da Tributação do Consumo. São Paulo: Fórum, 2007, p. 69 a 88.

TORRES, Heleno Taveira. Direito constitucional tributário e segurança jurídica: metódica da segurança jurídica do Sistema Constitucional Tributário. 2. ed. São Paulo: Editora Revista dos Tribunais, 2012. 
TORRES, Heleno Taveira . Direito constitucional tributário e segurança jurídica: metódica da segurança jurídica do Sistema Constitucional Tributário. 2. ed. São Paulo: Editora Revista dos Tribunais, 2012.

TORRES, Ricardo Lobo. Curso de direito financeiro e tributário. Rio de Janeiro: 10. ed. Rio de Janeiro: Renovar, 1993.

TORRES, Ricardo Lobo. É Possível a Criação do IVA no Brasil? SARAIVA FILHO, Oswaldo Othon; VASQUES, Sérgio: GUIMARÃES, Vasco Branco ( Org. ). IVA para o Brasil - Contributos para a Reforma da Tributação do Consumo. São Paulo: Fórum, 2007. p. $19-36$

TRAVIESO, Juan Antonio. Código de Derecho Internacional. Buenos Aires: Abeledo Perrot, 1999.

TRINDADE, Antônio Augusto Cançado. Princípios de direito internacional contemporâneo. Brasília: UnB, 1981.

TRUYOL Y SERRA, Antonio. História do direito internacional público. Lisboa: Novas Profissões, 1992.

TRUYOL Y SERRA, Antonio. Noções fundamentais de direito internacional público. Coimbra: Armênio Amado, 1962.

URRESTI, Esteban Juan; CARDOZO, Horacio Félix. Comentários sobre la instauración del impuesto al valor agregado en un Estado Federal. In: BALTHAZAR, Ubaldo Cesar (Org.). Reforma tributária e Mercosul: a instituição do IVA no direito tributário brasileiro. Belo Horizonte: Del Rey, 1999. p. 145-163.

VALDÉS COSTA, Ramón. Protección de los derechos del contribuyente a nivel internacional. Revista Tributaria, Montevideo, Instituto Uruguayo de Estudios Tributarios (IUET), v.15, n. 84, p. 207-232, mayo/junio 1988.

VALDÉS COSTA, Ramón. El principio de legalidade: el sistema uruguayo ante el derecho comparado. In: El principio de legalidad en el Derecho Tributario. Obra colectiva conteniendo los trabajos presentados al Simposio organizado por la Facultad de Derecho y Ciencias Sociales y el Instituto Uruguayo de Estudios Tributarios en octubre de 1986. Montevideo: Facultad de Derecho, 1986. p. 179-222.

VALDES, Nelly. El impuesto al valor agregado em el Uruguay. In: BALTHAZAR, Ubaldo Cesar (Org.). Reforma tributária e Mercosul: a instituição do IVA no direito tributário brasileiro. Belo Horizonte: Del Rey, 1999. p. 97-124.

VAN ROMPUY, Herman. Da guerra à paz: uma história europeia. Discurso de aceitação do Prémio Nobel da Paz atribuído à União Europeia/Oslo, 10 dezembro 2012.

VAZ, Alcides Costa. Cooperação, Integração e Processo Negociador: A Construção do MERCOSUL. Brasília: IBRI, 2002. 
VENEZIANO, Alicia. Análisis de redes intergubernamentales de las leyes de descentralización en Uruguay: por primera vez existen municipios. Revista Estudos de Política, Campina Grande, PB, v. 1, n. 1, p. 85-107, 2012.

VENEZIANO, Alicia. Desafíos e incertidumbres de la descentralización en Uruguay: impactos de la reforma constitucional. Revista Prisma, Montevideo, UCUDAL, n. 13, 2000 .

VIDAL, N. Bouza. Significado y alcance de la armonización de legislaciones em la Comunidad Europea. Revista de Instituciones Europeas, Vol. 8, n 2, 1981, pg. 397.

VIDAL, N. Bouza. Modalidades de unificación y de armonizacion de legislaciones em la Comunidade Económica Europea. Tratado de Derecho Comunitario Europeo, Tomo I, Civitas, Madrid, 1986, pgs 551-570.

VITTA, José María; GRECCHI, Ana María; BRUNOTTI, A. Análisis comparativo sobre legislación provincial del Impuesto sobre Ingresos Brutos. Buenos Aires: Consejo Federal de Inversiones, 2004.

VITTA, José María; GRECCHI, Ana María; FERULLO, Claudio. Impuesto sobre los ingresos brutos: asimetrías que deben eliminarse. Buenos Aires, Argentina, Undécimas Jornadas "Investigaciones en la Facultad" de Ciencias Económicas y Estadística, Escuela de Contabilidad, 2007. p. 1-18.

VIZCAÍNO, Catalina García. Derecho tributario: tomo 3: parte especial: el derecho tributario vigente: análisis de la legislación, doctrina y jurisprudência. Buenos Aires: Depalma, 1997.

VENTURA, Deisy de Freitas Lima. As assimetrias entre o MERCOSUL e a União Europeia: os desafios de uma associação inter-regional. Barueri. São Paulo: Manole, 2003.

VERDROSS, Alfred. Derecho internacional publico. Madrid: Aguilar, 1974.

VILAÇA, J. L. da Cruz. Tratado de Nice. Coimbra, Portugal: Livraria Almedina, 2001.

VILANOVA, Lourival. Norma Jurídica - Proposição Jurídica. Revista de Direito Público, São Paulo, n. 61, p. 12-26, jan./mar. 1982.

VILANOVA, Lourival. Estruturas Lógicas e o Sistema do Direito Positivo. São Paulo: Max Limonad. 1997.

VIOTTI, Paul \& KAUPPI, Mark. International Relations Theory: Realism, Pluralism, Globalism and Beyond. Boston: Allyn and Bacon, 1998.

WARD, Ian. A Critical Introduction to the European Law, Londres, 1996, Butterworths.

WOLKMER, Antônio Carlos. Integração interamericana, comunitarismo jurídico e cidadania supranacional. Revista de Informação Legislativa, Brasília, n. 35, p. 259- 265, out./dez., 1988. 
XAVIER, Alberto Pinheiro. Direito Tributário Internacional do Brasil. $4^{\mathrm{a}}$ Ed. Rio de Janeiro: Forense, 1998.

XAVIER, Alberto. Direito tributário internacional do Brasil: tributação das operações internacionais. $4^{\mathrm{a}}$ ed. atualizada. Rio de Janeiro: Forense, 1997.

XAVIER, Alberto. Tipicidade de tributação, simulação e norma antielisiva. São Paulo: Dialética, 2001.

ZÁRATE, Walter. Efectividad de la política tributaria em Paraguay: antes y después de la Reforma. Asunción: CADEP-OFIP), 2010.

ZARINI, Helio Juan. Análisis de la Constitución nacional: comentario exegético, origen, reformas, concordancias y antecedentes. 3. ed., ampl. y actual. Buenos Aires: Astrea, 1991.

YAMASHITA, Douglas. ICMS/IVA: Princípios especiais: capacidade contributiva, nãocumulatividade, destino e origem. São Paulo: I0B, 2000. 